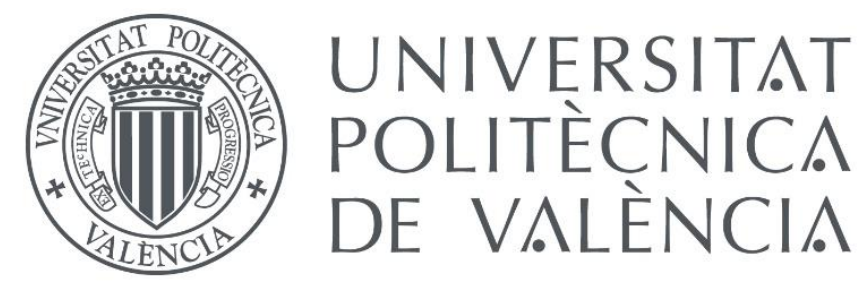

DEPARTAMENTO DE BIOTECNOLOGÍA

\title{
Genetic Structure of Diploid Gametes for the Production of Triploid Citrus Hybrids
}

PhD THESIS PRESENTED BY

\section{HOUSSEM ROUISS}

SUPERVISORS:

DR. LUIS NAVARRO LUCAS

DR. PATRICK OLLITRAULT

DR. PABLO ALEZA

TUTOR

DR. ALEJANDRO ATARES HUERTA 



\section{Acknowledgement}

It all started when my friends sent me several messages: Houssem congratulation, you got it, you got the scholarship for the PhD. And the journey begun .....

Firstly, I would like to express my sincere gratitude to my $\mathrm{PhD}$ directors Dr. Luis Navarro Lucas, Dr. Patrick Ollitrault and Dr. Pablo Aleza for their continuous support of my Ph.D study and related research, for their patience, motivation, and immense knowledge. Their guidance helped me in all the time of research and writing of this thesis.

Besides, I would like to thank my coordinator Dr. Alejandro Atarés for his insightful comments and encouragement.

The members of the IVIA and CIRAD institutes have contributed immensely to my personal and professional progress. To all my friends within those institutes you have been a source of friendships as well as good advice and collaboration, thank all of you for supporting me in writing, and incented me to strive towards my goal. Thanks again and again.

I would like to thank my family: my parents Houssine and Moufida who raised me with a love of science and supported me in all my pursuits and to my brothers Hassib and Hamza and sisters Hadhami and Haba and my aunt Fouzya for supporting me spiritually throughout this thesis.

To my loving, supportive, encouraging, and patient wife, my soul mate Sarra. To my little angel Aylen, for you 
"If we knew what it was we were doing, it would not be called research, would it?" - Albert Einstein 



\section{CONTENTS}

ABSTRACTS I

LIST OF FIGURES - X

LIST OF TABLES X XII

LIST OF ABBREVIATIONS XIV

INTRODUCTION 1

OBJECTIVES

CHAPTER 1: Tetraploid citrus progenies arising from FDR and SDR

unreduced pollen in 4x x 2x hybridizations. Tree Genetics \& Genomes (2017) 13:10.

CHAPTER 2: Unreduced Megagametophyte Production in Lemon Occurs via Three Meiotic Mechanisms, Predominantly Second-Division

Restitution. Frontiers in Plant Science (2017) doi: 10.3389/fpls.2017.01211.

CHAPTER 3: Doubled diploid 'Mexican' lime display preferential disomic segregation compatible with interploid crosses origin of $C$. Latifolia and $C$. aurantifolia triploid limes. Annals of Botany. Submitted 



\section{$\underline{\underline{\text { Abstract }}}$}

The citrus industry is an important source of incomes for both individual growers and producing countries. Therefore, breeding for quality especially seedlessness has a pivotal role for the market, since consumers demand seedless fruits. Recovery of triploid hybrids through ploidy manipulation is a very valuable methodology to recover seedless citrus varieties.

Citrus triploid hybrids can be recovered through $2 \mathrm{x} \times 2 \mathrm{x}$ taking advantage of the unreduced (2n) gametes formation. $2 \mathrm{x} \times 4 \mathrm{x}$ and $4 \mathrm{x} \times 2 \mathrm{x}$ sexual hybridizations are also widely exploited. Underlying the production mechanisms and genetic structures of diploid gametes is a key for optimizing polyploid breeding strategies. Two main mechanisms have been found in angiosperm for production of unreduced gametes: First Division Restitution (FDR) and Second Division Restitution (SDR). On the other hand, although tetraploid rootstocks display promising agronomic traits, their meiotic behavior and their segregation analysis is still mostly unknown in citrus. Disomic and tetrasomic models were defined as extreme models for tetraploid segregation, however, an intermediate inheritance model has been described for several crops.

In this framework, this thesis aimed to study three main aspects: (i) the mechanisms underlying unreduced pollen gamete formation in the diploid 'CSO' tangor hybrid used as male parent in $4 \times 1 \times 2 \times$ triploid breeding programs, (ii) the frequencies and mechanisms involved in the unreduced $2 \mathrm{n}$ female gametes production for 'Eureka Frost' and 'Fino' lemon genotypes, and (iii) the interspecific recombination and the resulting diploid gamete structures of doubled-diploid 'Mexican' lime to evaluate the possibility that natural interploid hybridization maybe the origin of $C$. latifolia ('Tahiti' lime type) and $C$. aurantifolia ('Tanepao' lime type) triploid varieties.

The production of 54 tetraploid hybrids from 4x x 2x sexual hybridizations allowed the analysis of the mechanisms underlying unreduced pollen gamete formation. SSR and SNP molecular markers revealed that the majority of these plants were obtained from unreduced $2 \mathrm{n}$ pollen of the diploid tangor parent. Then, the maximum-likelihood method based on parental heterozygosity restitution (PHR) of centromeric loci revealed that both FDR with predominant occurrence and to a lower extend SDR were the mechanisms leading to unreduced male gamete formation in the tangor studied. These observations were confirmed by the analysis of PHR pattern along the linkage group (LG) 2. To our knowledge, this is the first report of tetraploid citrus progenies arising from unreduced pollen and the first description of the coexistence of two meiotic restitution mechanisms (SDR and FDR) producing unreduced pollen in citrus.

In order to study the frequencies and the mechanisms involved in the unreduced $2 \mathrm{n}$ female gametes production in two different genotypes of lemon, we produced 43 triploid and tetraploid hybrids from 2x x 2x and 2x x 4x sexual hybridizations using 'Eureka Frost' and 'Fino' as female parents. The frequencies of $2 \mathrm{n}$ gamete production were respectively $4.9 \%$ and $8.3 \%$. The maximum-likelihood analysis and pattern of PHR along LG1 revealed that SDR is the main mechanism of unreduced female lemon gametes (88\%), followed by FDR or pre-meiotic doubling (PRD) (7\%) and post-meiotic genome doubling (PMD) mechanisms (5\%). 
This is the first report of the production of a large number of lemon progenies from $2 \mathrm{n}$ gametes and the first identification of a new mechanism, PMD that has never been observed in citrus and has rarely been described in other herbaceous or woody species.

Across both studies, we demonstrated at the methodological level the effectiveness of using two complementary approaches, the analysis of the PHR pattern in one LG and the maximum-likelihood method based on centromeric loci for distinguishing between the different mechanisms of unreduced gamete production.

We analyzed the meiotic mechanisms of a doubled diploid 'Mexican' lime, the interspecific recombination and the resulting diploid gamete structures combining a segregation analysis of SSR and SNPs markers, a cytogenetic study and pollen viability evaluation. We concluded that the doubled-diploid 'Mexican' lime had a predominantly disomic segregation for three LGs, intermediate inheritance with disomic tendency was found for five LGs and intermediate models for one LG. The resulting interspecific diploid gamete structures displayed high C. medica / C. micrantha heterozygosity. The revealed genetic structures of the diploid gametes produced by the doubled-diploid 'Mexican' lime are compatible with the hypothesis that 'Tahiti' and 'Tanepao' triploid varieties results from interploid hybridization involving a doubled-diploid 'Mexican' like lime. This disomic tendency limits the recombination and the diversity of the diploid gamete population; however the observed pollen viability restoration at tetraploid level could be advantageous for intensive breeding projects.

The implications for triploid breeding projects of the meiotic behavior leading to unreduced pollen in 'CSO' tangor, unreduced ovules in lemons and diploid gametes of the DD 'Mexican' lime are discussed. 


\section{$\underline{\underline{\text { Resumen }}}$}

La citricultura es una fuente importante de ingresos tanto para los citricultores como para los países productores. La mejora de la calidad e especialmente la ausencia de semillas en los frutos, es una exigencia del mercado de consumo en fresco ya que los consumidores no aceptan la presencia de semillas en los frutos. La obtención de híbridos triploides mediante la manipulación del nivel de ploidía es una metodología eficaz para la obtención de nuevas variedades de cítricos sin semillas.

En cítricos se pueden obtener híbridos triploides mediante cruzamientos $2 \mathrm{x}$ x $2 \mathrm{x}$ como consecuencia de la formación de gametos no reducidos (2n) y mediante hibridaciones sexuales entre parentales diploides y tetraploides (2x x 4x y 4x x 2x). La identificación de los mecanismos implicados en la formación de gametos no reducidos y las estructuras genéticas de los gametos diploides originados por los parentales tetraploides es crucial para optimizar las estrategias de mejora a nivel poliploide. En angiospermas se han descrito principalmente dos mecanismos de formación de gametos no reducidos, Restitución de la Primera División meiótica (FDR) y Restitución de la Segunda División meiótica (SDR). Por otro lado, se ha observado que los portainjertos tetraploides de cítricos presentan un comportamiento agronómico muy interesante, pero existe un gran desconocimiento sobre las meiosis y modelos de segregación de este tipo de plantas. Los modelos disómico y tetrasómico son modelos extremos para la segregación de genotipos tetraploides, aunque se han descrito modelos de segregación intermedios para diferentes cultivos.

En este contexto, esta tesis doctoral estudia tres aspectos principales: (i) los mecanismos responsables de la formación de gametos no reducidos de polen originados por un híbrido diploide entre clementina y naranjo (tangor 'CSO') que se ha utilizado como parental masculino en hibridaciones sexuales $4 \mathrm{x} \times 2 \mathrm{x}$, (ii) las frecuencias $\mathrm{y}$ los mecanismos implicados en la producción de gametos no reducidos femeninos en dos genotipos de limón, 'Eureka Frost' y 'Fino', y (iii) el análisis de la recombinación interespecífica y las estructuras de los gametos diploides originados por la lima 'Mejicana' doble diploide con el objetivo de evaluar la posibilidad de que las variedades triploides de lima C. latifolia (lima tipo `Tahiti') y C. aurantifolia (lima tipo 'Tanepao') se hayan originado a partir de un cruzamiento natural a nivel interploide.

La obtención de 54 híbridos tetraploides a partir de hibridaciones sexuales $4 \mathrm{x}$ x $2 \mathrm{x}$ permitió analizar los mecanismos responsables de la formación de gametos no reducidos de polen. El análisis de estas plantas con marcadores moleculares SSRs y SNPs reveló que la mayoría de estas plantas se obtuvieron a partir de gametos no reducido de polen del parental masculino diploide tangor 'CSO'. A continuación, el análisis mediante la utilización del método de máxima verosimilitud basado en la restitución de la heterocigosidad parental (PHR) en los loci centroméricos indicó que FDR y SDR son los mecanismos implicados con una mayor dominancia de FDR respecto SDR. Estos resultados se confirmaron posteriormente mediante el análisis de la restitución de la heterocigosidad en el grupo de ligamiento (LG) 2. Con los datos publicados hasta la fecha, es la primera vez que se han obtenido progenies tetraploides de cítricos mediante gametos no reducidos de polen y es la primera descripción en cítricos de la coexistencia de dos mecanismos de restitución meiótica, SDR y FDR, implicados en la formación de gametos $2 \mathrm{n}$ de polen. 
Con el fin de estudiar las frecuencias y los mecanismos implicados en la producción de gametos no reducidos en dos genotipos diferentes de limón, se obtuvieron 43 híbridos triploides y tetraploides a partir de hibridaciones sexuales $2 \mathrm{x}$ x $2 \mathrm{x}$ y $2 \mathrm{x}$ x $4 \mathrm{x}$ utilizando los limones diploides 'Eureka Frost' y 'Fino' como parentales femeninos. Las frecuencias de producción de gametos $2 \mathrm{n}$ fueron respectivamente $4,9 \%$ y $8,3 \%$. El análisis de máxima verosimilitud y el patrón de PHR a lo largo del LG1 reveló que SDR es el mecanismo principal implicado en la formación de gametos no reducidos femeninos (88\%), seguido por FDR o duplicación del genoma pre-meiosis (PRD) (7\%) y se identificó un nuevo mecanismo originado a partir de la duplicación del genoma post-meiosis (PMD) (5\%). En este trabajo se describe por primera vez en cítricos la producción de un elevado número de híbridos de limón a partir de gametos $2 \mathrm{n}$ y es la primera vez que se identifica un nuevo mecanismo PMD que nunca se ha observado en cítricos y rara vez se ha descrito en otras especies herbáceas o leñosas. En ambos estudios se demostró a nivel metodológico la efectividad del uso de dos métodos complementarios, el análisis del patrón de PHR a lo largo de un LG y el método de máxima verosimilitud basado en la utilización de loci centroméricos para distinguir entre los diferentes mecanismos implicados en la formación de gametos no reducidos en limón.

También se ha analizado el modelo de segregación cromosómica de la lima 'Mejicana' doble diploide así como la recombinación interespecífica y las estructuras de los gametos diploides resultantes. Este trabajo se ha realizado mediante el análisis de la viabilidad del polen junto con un análisis citogenético y con marcadores SSRs y SNPs. Estos trabajos nos han permitido concluir que la lima 'Mejicana' DD presenta una segregación predominantemente disómica para tres LGs, herencia intermedia con tendencia disómica para cinco LGs y un tipo de segregación intermedia para un LG. Las estructuras de los gametos diploides interespecíficos resultantes mostraron una alta heterocigosis en C. medica/C. micrantha, parentales de la lima 'Mejicana'.

Las estructuras genéticas observadas en los gametos diploides de la lima 'Mejicana' doble diploide son compatibles con la hipótesis de que las variedades triploides de lima 'Tahiti' y 'Tanepao' se obtuvieran a partir de una hibridación interploide en la cual uno de los parentales fuese la lima 'Mejicana' doble diploide. El tipo de segregación disómico conlleva una limitación de la recombinación y la diversidad genética de la población de gametos diploides. Sin embargo la viabilidad del polen de la lima 'Mejicana' DD en comparación con la lima 'Mejicana' diploide permite la utilización de este genotipo como parental para la obtención de nuevas variedades de lima en programas de mejora genética.

Finalmente, se discuten las implicaciones en los programas de mejora genética para la obtención de híbridos triploides el comportamiento meiótico que origina la formación de gametos no reducidos de polen en el tangor 'CSO', la formación de gametos no reducidos de óvulo en los limones y los gametos diploides producidos por la lima 'Mejicana' doble diploide. 


\section{$\underline{\underline{\text { Resum }}}$}

La indústria dels cítrics és una font important d'ingressos tant per als productors individuals com pels països productors. Per tant, la millora de la qualitat, especialment l'obtenció de varietats sense llavors va tindre un paper fonamental per al mercat, ja que els consumidors demanen fruits sense llavors. L'obtenció d'híbrids triploides mitjançant la manipulació de la ploïdia podria ser una metodologia valuosa per a obtindre varietats de cítrics sense llavors.

Els híbrids triploides de cítrics es poden obtindre a partir de creuaments $2 \mathrm{x}$ x $2 \mathrm{x}$ aprofitant la formació de gàmetes no reduïts (2n). Les hibridacions sexuals $2 \mathrm{x} x$ 4x i $2 \mathrm{x}$ $\mathrm{x} 4 \mathrm{x}$ són també àmpliament utilitzades. Els mecanismes de producció i les estructures genètiques de les gàmetes diploides son la clau per a l'optimització de les estratègies de millora de poliploides. Quant a les gàmetes no reduïts, s'observen dos mecanismes principals en angiospermes: Restitució en la Primera Divisió (RPD) i Restitució en la Segona Divisió (RSD). D'altra banda, tot i que els portaempelts tetraploids mostren trets agronòmics prometedors, el seu comportament meiòtic i la anàlisi de la seua segregació son encara desconeguts en els cítrics. Els models disómic i tetrasómic es van definir com a models extrems per a la segregació tetraploide, però, el model d'herència intermèdia s'ha descrit per a diversos cultius.

Aquesta tesi ha tingut com a objectius l'estudi de (i) els mecanismes subjacents a la formació de pol·len de gàmetes no reduïts al tangor híbrid diploide 'CSO', utilitzat com a progenitor masculí en els programes de millora de triploides $4 \mathrm{x} \times 2 \mathrm{x}$ (ii) les frequiències $\mathrm{i}$ els mecanismes implicats en la producció gàmetes $2 \mathrm{n}$ no reduïts en la femella als genotips de llimona 'Eureka Frost' i Fina' (iii) la recombinació interespecífica i les estructures resultants de gàmetes diploides del doble-diploide de 'llima Mèxicana' per avaluar la possibilitat que la hibridació interploid natural potser l'origen de les varietats triploides C. latifolia (llima tipus 'Tahiti') i C. aurantifolia (llima tipus 'Tanepao').

La producció de 54 híbrids tetraploides obtinguts d hibridacions sexuals 4 x x 2x va permetre l'anàlisi dels mecanismes de formació de gàmetes no reduïts de pol·len. Els marcadors moleculars SSR i SNP van revelar que la majoria d'aquestes plantes es van obtenir de pol-len $2 \mathrm{n}$ no reduït del parental diploide tangor. Llavors, el mètode de màxima probabilitat basat en la restitució de 1 heterocigositat parental (RHP) de loci centromèrics va revelar que tant RPD, amb ocurrència predominant, com RSD van ser els mecanismes que condueixen a la formació de gàmetes masculins no reduïts en aquest tangor. Aquestes observacions van ser confirmades per l'anàlisi de patró de RHP al llarg del cromosoma 2. Des del nostre coneixement, aquest és el primer estudi de progènies de cítrics tetraploides derivats de pol·len no reduït i la primera descripció de la coexistència de dos mecanismes de restitució meiòtiques (RPD i RSD) produint pol·len no reduït en els cítrics.

Per tal d'estudiar les freqüències i els mecanismes implicats en la producció de gàmetes 2n sense reduir de la femella, en dos genotips diferents de llimona, vam obtenir 43 híbrids triploides i tetraploides dhibridacions sexuals $2 \mathrm{x} \times \mathrm{x} 2 \mathrm{x}$ i $4 \mathrm{x}$ x $2 \mathrm{x}$ utilitzant 'Eureka Frost ' i 'Fino' com progenitors femenins. Les freqüències de la producció de 
gàmetes $2 \mathrm{n}$ van ser, respectivament, 4,9\% i 8,3\%. L'anàlisi de màxima probabilitat i el patró de RHP al llarg del cromosoma 1 van revelar que RSD és el principal mecanisme de gàmetes no reduïts en la llimona utilitzada com parent femení (88\%), seguit pels mecanismes RPD o duplicació pre-meiòtica (DPR) (7\%) i la duplicació del genoma post-meiòtica (DPM) (5\%).

Per primera volta en els cítrics $s$ ha obtingut un gran nombre de progènie de llimona a partir de gàmetes $2 \mathrm{n}$ i s ha identificat un nou mecanisme, el DPM que poques vegades s'ha descrit en altres espècies herbàcies o llenyoses.

A través dels dos treballs, hem demostrat, a nivell metodològic, l'eficàcia d'utilitzar dos enfocaments complementaris, és a dir, l'anàlisi del patró de RHP en un cromosoma amb el mètode de màxima probabilitat basat en loci centromèrics per distingir entre els diferents mecanismes de la producció de gàmetes no reduïts .

Es van analitzar els mecanismes meiòtics d'un doble-diploide 'llima Mèxicana', la recombinació interespecífica i les estructures resultants de gàmetes diploides combinant una anàlisi de segregació de marcadors SSR i SNP, un estudi citogenètic i l'avaluació de la viabilitat del pol·len. Hem arribat a la conclusió que el doble-diploide de 'llima Mèxicana' tenia una segregació predominantment disómica en tres cromosomes, herència intermèdia amb tendència disómica en cinc cromosomes $\mathrm{i}$ els models intermedis per a un altre. Les estructures resultants de gàmetes diploides interespecífiques mostren alta heterozigositat $C$. medica / C. micrantha. Les estructures genètiques revelades dels gàmetes diploides produïts pel doble-diploide de 'llima Mèxicana' són compatibles amb la hipòtesi que les varietats triploides 'Tahiti' i 'Tanepao' resulten de la hibridació interploide que impliquen un doble-diploide de tipus 'llima Mèxicana'. Aquesta tendència disómica limita la recombinació i la diversitat de la població de gàmetes diploides, però, la restauració de la viabilitat del pol·len observat a nivell tetraploide podria ser avantatjós per a projectes de millora en cultius intensius.

Les implicacions per a projectes de millora triploide, del comportament meiòtic que condueix al pollen no reduït en el tangor 'CSO', els òvuls no reduïts en les llimones i les gàmetes diploides del doble-diploide de llima 'Mexicana', es discuteixen en aquesta tesi. 


\section{Résumé}

L'agrumiculture est une source importante de revenus pour les producteurs à titre individuels ainsi que pour les pays producteurs. L'amélioration génétique de la qualité, et en particulier l'aspermie, est essentielle pour répondre à la demande du marché. En effet, beaucoup de consommateurs préfèrent des fruits sans pépins. La création $\mathrm{d}$ hybrides triploïdes moyennant la manipulation de la ploïdie est une approche très efficace pour sélectionner des variétés sans pépins.

Les hybrides triploïdes d'agrumes peuvent être obtenus par des croisements entre variétés diploïdes en profitant de la formation de gamètes non réduits $(2 \mathrm{n})$. Les hybridations inter-ploïdes $2 \mathrm{x}$ x $4 \mathrm{x}$ et $4 \mathrm{x}$ x $2 \mathrm{x}$ sont également largement exploitées. La détermination des mécanismes de production de gamètes diploïdes et des structures génétiques en découlant est décisive pour l'optimisation des stratégies d'amélioration des polyploïdes. Deux mécanismes majeurs ont été observés chez les angiospermes pour la production des gamètes non réduits: la restitution de la première division (FDR) et la restitution de la deuxième division (SDR). D'autre part, malgré l'importance agronomique des porte-greffes tétraploïdes d'agrumes, leurs comportements méiotiques et leurs modes de ségrégation sont encore inconnus. Les modèles disomique et tétrasomique ont été définis comme les modèles extrêmes pour la ségrégation des tétraploïdes, mais des modèles de ségrégation intermédiaires ont été décrit pour plusieurs espèces.

Dans ce cadre, cette thèse visait l'étude de trois aspects principaux: (i) mécanismes responsables de la formation des gamètes mâles non réduits pour l'hybride tangor diploïde 'CSO' utilisé comme parent male dans des programmes d'hybridation 4x x 2x, (ii) les fréquences et les mécanismes impliqués dans la production d'ovules non réduits pour deux génotypes de citronnier 'Eureka Frost' et 'Fino', et (iii) la recombinaison interspécifique et les structures génétiques des gamètes diploïdes résultant de la lime 'Mexicaine' diploïde doublée pour vérifier l'hypothèse que des hybridations interploïdes naturels aient pu être à l'origine des variétés triploïdes de C. latifolia (lime type 'Tahiti') et $C$. Aurantifolia (lime type 'Tanepao').

La production de 54 hybrides tétraploïdes par croisements 4x x 2x a permis l'analyse des mécanismes responsables de la formation de gamètes non réduits du pollen du tangor 'CSO'. Des marqueurs moléculaires SSRs et SNPs ont révélé que la majorité de ces plantes dérivaient de pollen non réduit du parent tangor diploïde. Ensuite, la méthode de maximum de vraisemblance basée sur la restitution de 1 hétérozygotie parentale (PHR) des loci centromériques a révélé que le pollen diploïde issu d une restitution de la première division de la méiose (FDR) était prédominant (64.1\%) avec toutefois une proportion non négligeable (18.8\%) de $2 \mathrm{n}$ pollen issus de SDR. Ces observations ont été confirmées par l'analyse de la distribution de la restitution de 1 hétérozygotie parentale (PHR) au niveau du groupe de liaison 2. A notre connaissance, il s'agit du premier rapport sur des hybrides d'agrumes tétraploïdes obtenus à partir de pollen non réduit et une première description de la coexistence de deux mécanismes de restitution méiotique (SDR et FDR) produisant du pollen non réduit chez les agrumes. 
Afin d'étudier les fréquences et les mécanismes impliqués dans la production d'ovules non réduits pour deux génotypes de citronnier, nous avons produit 43 hybrides triploïdes et tétraploïdes à partir des croisements $2 \mathrm{x} \times 2 \mathrm{x}$ et $2 \mathrm{x} \times 4 \mathrm{x}$ en utilisant 'Eureka Frost' et 'Fino' comme parents femelle. Les fréquences de production des gamètes $2 \mathrm{n}$ ont été, respectivement, $4,9 \%$ et de $8,3 \%$. L'analyse du maximum de vraisemblance basé sur la PHR des loci centromériques et la distribution de la PHR le long du LG1 ont révélé que la majorité des gamètes non réduits résultaient de SDR (88\%), suivi par la FDR, le doublement pré-méiotique (PRD) (7\%) et le doublement post-méiotique (PMD) (5\%).

Il s'agit d'une première description de la production d'un grand nombre $\mathrm{d}$ hybrides polyplö̈des de citronnier provenant de gamètes $2 \mathrm{n}$ et de la première identification d'un nouveau mécanisme, PMD qui n'avait pas été décrit auparavant chez les agrumes et rarement chez d'autres espèces herbacées ou ligneuses.

Pour les deux études, nous avons confirmé au niveau méthodologique l'efficacité de l'utilisation de deux approches complémentaires (analyse de la distribution de la PHR au niveau d'un LG et méthode de maximum de vraisemblance basée sur des loci centromériques) pour distinguer entre les différents mécanismes pouvant produire des gamètes non réduits.

Nous avons analysé les fonctionnements méiotiques d'un limettier 'Mexicain' diploïde doublée (DD), la recombinaison interspécifique et les structures de gamètes diploïdes en combinant une analyse de ségrégation de marqueurs SSRs et SNPs, une étude cytogénétique et une évaluation de la viabilité du pollen. Nous avons conclu que le limettier 'Mexicain' DD avait une ségrégation essentiellement disomique au niveau de trois groupes de liaison (LGs), intermédiaire avec une tendance disomique pour cinq LGs et intermédiaire pour un LG. Une hétérozygotie $C$. medical $C$. micrantha élevée des gamètes diploïdes a été mise en évidence.

Ces structures génétiques des gamètes diploïdes produites par le limettier 'Mexicain' DD sont compatibles avec l'hypothèse proposant que les variétés triploïdes 'Tahiti' et 'Tanepao' résultent d'une hybridation interploïde impliquant un limettier DD de type 'Mexicain'. Cette tendance disomique limite la recombinaison et la diversité de la population de gamètes diploïdes. Cependant, la restauration de la viabilité du pollen observée au niveau tétraploïde pourrait être avantageuse pour des programmes d'amélioration du limettier au niveau triploïde.

Les implications pour les programmes d'amélioration des triploïdes des mécanismes méiotique produisant du pollen non réduit pour le tangor 'CSO', des ovules non réduits pour les citronniers et des gamètes diploïdes de la lime 'Mexicaine’ DD sont discutés. 



\section{LIST OF FIGURES}

Figure 1. Citrus (a) 'Pineapple' flower, (b) 'Mexican' lime pollinated flower and (c;d) fruit set in 'Eureka Frost' lemon and tetraploid $C$. clementina respectively..............8

Figure 1.1. Electropherograms obtained using mCrCIR03C08 SSR marker in a: diploid tangor 'CSO', b: tetraploid 'Moncada' mandarin, c: tetraploid hybrid displaying the alleles of both parents recovered from MCSO hybridization. The numbers indicate the size of alleles in nucleotides (nt) for each genotype...

38

Figure 1.2. Plot of normalized $A, T$ allele signals from cluster analysis over 54 tetraploid hybrids from the hybridization between tetraploid 'Fina' clementine and diploid tangor 'CSO' with the 2p21022555 SNP marker. Tetraploid hybrids (AAAA) and (AATT) originated from homozygous unreduced pollen grain (AA and TT) and tetraploid hybrids (AAAT) originated from heterozygous unreduced pollen grain (AT)

Figure 1.3. Observed parental heterozygosity restitution values for $2 \mathrm{n}$ pollen gametes classified by mechanism of unreduced gamete formation for markers in LG 2. Positions, according to clementine genetic map (Ollitrault et al., 2012). Blue line corresponds to FDR and red line corresponds to SDR mechanism and vertical line corresponds with the centromere location (Aleza et al., 2015)

Figure 1.4. UPGMA tree obtained from allelic data of $2 n$ pollen gametes produced by the diploid 'CSO' tangor (black) originated by FDR (red) and SDR (blue) mechanisms

46

Figure 2.1. Electropherograms of a triploid and a tetraploid hybrid recovered from EuIch and FinMac hybridizations using SSR marker JK-TAA 41. A. 'Fino' and 'Eureka Frost' lemons displayed the same allelic configuration for this marker; B. $C$. macrophylla; C. tetraploid hybrid with four different alleles from 'Fino' $\mathrm{x} 4 \mathrm{x} C$. macrophylla hybridization. D. C. ichangensis; E. Triploid hybrids with two alleles from the female parent 'Eureka Frost' lemon and one from the male parent $C$. ichangensis. nt: nucleotides

Figure 2.2. Plot of A, G allele signals of SNP marker CiC5950-02 representing triploid (A) and tetraploid (B) hybrids from EuIch and FinMac sexual hybridizations. Letters indicate the allelic configuration for each hybrid

69

Figure 2.3. Evolution of maternal heterozygosity restitution values of the analyzed SSR and SNP markers in LG 1 considering the significance of the obtained LOD values for each hybrid from 'Eureka Frost' and 'Fino' lemons with conclusive and inconclusive SDR 2n gametes. Black dot indicates the centromere position on the reference clementine genetic map (Ollitrault et al., 2012a)

70

Figure 2.4. Evolution of maternal heterozygosity restitution values of the analyzed SSR and SNP markers in LG 1 considering both populations, 'Eureka Frost' and 'Fino' lemon SDR 2n gametes. Black dots indicate the centromere position on the reference clementine genetic map (Ollitrault et al., 2012a) 
Figure 2.5. Multilocus configuration of the two fully homozygous plants recovered from FinMac hybridization with six molecular markers located on LG 1. Yellow indicates the presence of homozygous alleles inherited from $C$. aurantium, and green indicates those from $C$. medica

Figure 3.1. Pollen grains of tetraploid 'Mexican' lime stained with aceto-carmine. Bold red color are viable and colorless (blue) are non-viable.

Figure 3.2. Chromosome pairing configuration, a: Pollen Mother Cells (PMC) of the tetraploid 'Mexican' lime. b, Schematic interpretation of (a) 1 univalent (blue colour) + 12 bivalents (black colour) +1 trivalent (green colour) +2 tetravalents (red colour). c, Open tetravalent (arrow). d, e, f closed (ring) tetravalents (arrows). .87

Figure 3.3. Individual meiotic configuration of each observed PMC for tetraploid 'Mexican' lime. 88

Figure 3.4. Illustration of tetraploid hybrids genotyping. a. Electroferogram of a tetraploid hybrid recovered from hybridization between tetraploid Clemenules 'clementine and tetraploid 'Mexican' lime with mCrCIR07F11 SSR marker. nt : nucleotides. b. Plot of X and Y allele signals of the 1P199494 SNP marker representing tetraploid hybrids from the same hybridization. Letters indicate the allelic configuration for each genotype 89

Figure 3.5. Distribution of PHR value among markers (a) and gametes (b) for diploid gametes obtained from tetraploid 'Mexican' lime. 90

Figure 3.6. Comparative mapping between tetraploid 'Mexican' lime and diploid and tetraploid 'Clemenules' a: Tetraploid 'Mexican' lime (cM); b: diploid Clementine (physical; Mb); c: diploid Clementine (genetics; cM); d: tetraploid Clementine (cM). The centromere of each linkage group is indicated in green in the diploid Clementine map. .93

Figure 3.7. Interpretation for reconciliation of microsporogenesis observations in diploid and doubled diploid 'Mexican' lime: double inversion can produce closed tetravalent during doubled diploid meiosis 95 


\section{LIST OF TABLES}

Table 1.1. Information on used molecular markers with their Gene Bank or Phytozome accesion, position in the Clementine reference genetic map (Ollitrault et al., 2012b), parental genotypes and bibliographic reference.

35

Table 1.2. Analysis at individual and population level of the origin of 'CSO' tangor $2 \mathrm{n}$ gametes recovered from DD 'Moncada' mandarin by 'CSO' diploid tangor sexual hybridization using markers close to the centromeres of all LGs and the LOD score test probability ratio for SDR/FDR.

41

Table 1.3. Analysis at individual level of the origin of ' $\mathrm{CSO}^{\prime}$ ' tangor $2 \mathrm{n}$ gametes recovered from DD 'Fina' clementine by 'CSO' diploid tangor sexual hybridization using markers close to the centromeres of five different LGs and the LOD score test probability ratio for SDR/FDR.

42

Table 2.1. Information about the molecular markers used in this study, including GenBank accession numbers, genetic distances, noted alleles, and references.

Table 2.2. Plant regeneration and ploidy level of plants recovered from 'Eureka Frost' $x$ 'Fortune' mandarin (EuFor), 'Eureka Frost' x C. ichangensis (EuIch) and 'Fino' x $C$. macrophylla

(FinMac)

Table 2.3. Heterozygous and homozygous profiles for $2 \mathrm{n}$ gametes from EuFor hybridization analyzed using SSR and SNP markers close to the centromere of each LG and the LOD score test for SDR/FDR and SDR/PRD probability

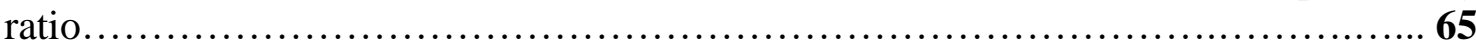

Table 2.4. Heterozygous and homozygous profiles for $2 \mathrm{n}$ gametes from EuIch hybridization analyzed using SSR and SNP markers close to the centromere of each LG and the LOD score test for SDR/FDR and SDR/PRD probability ratio.

Table 2.5. Heterozygous and homozygous profiles for $2 n$ gametes from FinMac hybridization analyzed using SSR and SNP markers close to the centromeres of seven LGs and the LOD score test for SDR/FDR and SDR/PRD probability ratio. 68

Table 2.6. Number of observed crossover events on each arm of chromosome I based on analysis of 27 genotypes recovered from 'Eureka Frost' lemon pollinated with $C$. ichangensis and 'Fortune' mandarin using six molecular markers. Numbers between brackets indicate the number of complementary crossovers. 73

Table 3.1. Molecular markers used to study the genetic structure of the diploid gametes produced from the tetraploid 'Mexican' lime, with their gene bank accesion, genetic position, noted alleles and bibliographic reference. 
Table 3.2. Chromosome configuration at meiosis in pollen mother cells (PMC) of the tetraploid

lime

86

Table 3.3. Interspecific structures of the 'Mexican' lime diploid gametes for the nine LGs. 91

Table 3.4. Estimation of $\tau$ and PP from centromeric loci of the nine LG of 'Mexican' lime $4 \mathrm{x}$ .91

Table 3.5. Average recombination rates per $L G(\mathrm{cM} / \mathrm{Mb})$ for three segregating progenies. 


\section{LIST OF ABBREVIATIONS}

- ABS : Alternaria Brown Spot

- CIRAD: Centre de Coopération Internationale en Recherche Agronomique pour le Développement

- Cl4x: Doubled-Diploid 'Clemenules' Clementine

- CSO: Diploid Hybrid Tangor (clementine x sweet orange)

- CVC: Citrus Variegated Chlorosis

- DC: Distance to the Centromere

- DD: Doubled Diploid

- DR: Double Reduction

- EuFor: Hybridization Between 'Eureka Frost' emon and 'Fortune' mandarin

- EuIch Hybridization between 'Eureka Frost' lemon and C. ichangensis

- FCSO: Hybridization between 'CSO' diploid tangor and 'Fina' clementine

- FDR: First Division Restitution

- FinMac: Hybridization between `Fino' lemon and C. macrophylla

- GMP: Genetic Map Position

- HLB: Huanglongbing Disease

- HTA: Half-tetrad Analysis

- IC: Chromosome Interference Coefficient

- IVIA: Instituto Valenciano de Investigaciones Agrarias

- LG: Linkage Group

- ML4x: Doubled-Diploid `Mexican` Lime

- MSCO: Hybridization between 'CSO' diploid tangor and 'Moncada' mandarin

- PHR: Parental Heterozygosity Restitution

- PMC: Pollen Mother Cells

- PMD: Post-Meiotic Genome Doubling

- PP: Preferential Pairing

- PRD: Pre-Meiotic Doubling

- SDR: Second Division Restitution

- SNP: Single Nucleotide Polymorphism Markers

- SSR: Simple Sequence Repeat Markers

- UPGMA: Unweighted Pair Group Method with Arithmetic Mean

- $\tau$ : Tetrasomic Rate 



\section{INTRODUCTION}





\section{INTRODUCTION INDEX}

I. ECONOMIC IMPORTANCE OF CITRUS ......................... 4

II. TAXONOMY, CLASSIFICATION, ORIGIN AND DISTRIBUTTION

OF CULTIVATED CITRUS .................................... 4

II.1. Taxonomy and classification............................. 4

II.2. Origin and distribution of cultivated citrus plants.............. 5

III. REPRODUCTIVE BIOLOGY ................................. 7

IV. MAIN BIOTIC AND ABIOTIC STRESS IN CITRUS ................. 9

IV.1. Biotic stress............................................. 9

IV.2. Abiotic stress.............................................. 10

V. MAIN OBJECTIVES OF CITRUS BREEDING PROGRAMS ............ 11

V.1. Main objectives of scion breeding programs ................... 11

V.2. Main objectives of rootstocks breeding programs .................. 12

VI. CITRUS BREEDING: STRATEGIES, TOOLS AND MAIN

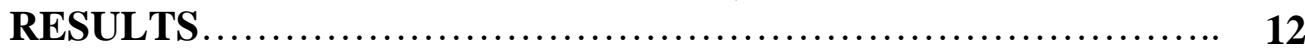

VI.1. Spontaneous mutations .................................. 12

VI.2. Induced mutagenesis................................... 13

VI.3. Sexual breeding .......................................... 13

VI.3.1. Sexual breeding for seedlessness at diploid Level......... 14

VI.3.2. Sexual breeding for seedlessness at triploid Level.......... 14

VI.3.3. Tetraploid citrus genetic pool diversification............ 15

VI.4. Biotechnological tools for citrus breeding ...................... 17

VI.4.1. Genetic transformation............................ 17

VI.4.2. Genome Editing ................................. 17

VI.4.3. Viral Vectors........................................ 17

VI.4.4. Genetic and genomic resources...................... 18

VII. SEXUAL AND SOMATIC CITRUS POLYPLOIDY .................. 19

VII.1.1. Unreduced gametes................................... 19

VII.1.2. Diploid gametes produced by tetraploid plants.............. 22 


\section{ECONOMIC IMPORTANCE OF CITRUS}

Citrus plants are grown in more than 100 tropical, subtropical and Mediterranean countries and represent the leading fruit crop in the world with more than 137 million tons tons (MT) produced in 2014 with 8.9 million hectares in cultivation. Sweet orange represents a very large part of this production (51.7\%), followed by clementines, mandarins and tangerines $(21.8 \%)$, lemons and limes $(11.8 \%)$ and grapefruit $(6.1 \%)$. China is the main producer country followed by Brazil, India, United States of America (USA), Mexico and Spain (FAOSTAT, 2014).

Citrus fruits are used for the fresh fruit market and for processing, mainly for orange juice production. Around 18.6\% of citrus fruit production is processed, being Brazil and USA the most important countries covering $75 \%$ of the world orange juice markets. For the fresh fruit market, China, Brazil, Mexico, India and Spain are the most important countries, producing around 58\% of the total global production (FAOSTAT, 2014).

Spain produced more than 7 million tons in 2014 with a cultivated surface of 300.000 ha, being sweet oranges the $49.5 \%, 33.8 \%$ for mandarins, and $16.7 \%$ lemons and grapefruit. Spain exports more than $50 \%$ of its citrus fruit production. The Valencia Community is the first Spanish citrus producer with $44.9 \%$ of total Spanish citrus production reaching 3.1 million tons and a cultivated surface over 161.000 ha, leaded by sweet oranges (49\%), mandarins (43\%) and followed by lemons (8\%) (GVA, 2015).

\section{TAXONOMY, CLASSIFICATION, ORIGIN AND DISTRIBUTION OF CULTIVATED CITRUS}

\section{II.1. Taxonomy and classification}

The genus Citrus was established by Carl Linneaus in 1753 (Swingle and Reece, 1967) within the order Geraniales, suborder Geraniineae, family Rutaceae, subfamily Aurantioideae, tribe Citreae, and subtribe Citrinae which includes Fortunella, Eremocitrus, Poncirus, Clymenia, Microcitrus and Citrus genera. The most common citrus cultivars and rootstocks are included in the Fortunella, Poncirus and Citrus genera.

Poncirus includes only the Poncirus trifoliata (L.) Raf species and is distinguishable by its trifoliate and deciduous leaves and it could represent the ancestor of the true citrus that spread to the north of China, adapting its morphological and resistance characteristics to extreme conditions of winter cold (Swingle and Reece, 1967). P. trifoliata is commonly used as a rootstock in acid soils. Furthermore, due to its resistance to the citrus tristeza virus, it is widely used as a progenitor in rootstock development programs to obtain interspecific hybrids such as citranges $(C$. sinensis $\mathrm{x} P$. trifoliata) and citrumelos (C. paradisi x P. trifoliata).

Fortunella is characterized by small fruits with sweet and edible peel. Its origin is southeast China and is constituted by four species: F. margarita (Lour.) Swing., $F$. japonica (Thunb.) Swing., F. polyandra (Ridl.) Tan. and F. hindsii (Champ.) Swing. They are valued as ornamental plants and used in different breeding programs with the objective to introduce in the progenies cold tolerance and citrus canker and Phytophtora resistance (Krueger and Navarro, 2007). 
Citrus is the genus with greater economic importance of the subfamily Aurantioideae. Two major taxonomic systems for botanical classification are used for this genus. Swingle's system is relatively simple as it contains 16 species (Swingle and Reece, 1967). It divided Citrus into two subgenera, Eucitrus and Papeda. The former one include $C$. medica L., C. aurantium L., C. limon (L.) Burn. f., C. aurantifolia (Christm.) Swing., C. grandis (L.) Osb., C. sinensis (L.) Osb., C. reticulata Blanco., C. paradisi Macf., C. indica Tan. and C. tachibana (Mak.) Tan.

The Papeda subgenus include $C$. ichangensis Swing., $C$. latipes (Swing.) Tan., $C$. hystrix D.C., C. micrantha Wester., C. celebica Koord. and C. macroptera Montr. Both subgenera are separated by their morphological characteristics and the chemical components of their flowers, leaves and fruits. Eucitrus contains "edible" citrus fruits, while the Papeda fruits have high concentrations of acrid oil, rendering them inedible (Spiegel-Roy and Goldschmidt, 1996).

Alternatively, Tanaka's system divided the Citrus genus into two subgenera, Archicitrus and Metacitrus. They included 162 species and the most important differences in comparison with Swingle's system affects mandarins, lemons and limes. Indeed, Tanaka subdivided limes to three species, $C$. aurantifolia, C. latifolia Tan. and C. limettioides Tan. As for mandarins, Swingle defined only one species $C$. reticulata Blanco, while Tanaka's system added other species like C. deliciosa Ten., C. unshiu Marc., C. clementina Hort. ex Tan., C. tangerina Hort. ex Tan. and C. nobilis Lour. (Swingle and Reece, 1967).

From an agronomic point of view, Tanaka's classification is better adapted to the characteristics of the different agronomic groups, and it is widely used to manage germplasm collections (Krueger and Navarro, 2007).

\section{II.2. Origin and distribution of cultivated citrus plants}

Many diversity studies (Tanaka, 1954; Webber et al., 1967; Scora, 1975; 1988) concluded that the center of origin of the majority of citrus species and its related genera was Southeast Asia, especially East India, North Burma, and Southwest China.

The domestication of edible citrus began several thousand years ago, and various biochemical and molecular studies suggested that only citron ( $C$. medica), mandarin $(C$. reticulata), pummelo (C. maxima) and $C$. micrantha constituted the ancestors of all cultivated Citrus species (Nicolosi et al., 2000; Barkley et al., 2006; Ollitrault et al., 2012b; Garcia-Lor et al., 2013b; Curk et al., 2016).

It is well accepted that $C$. medica is native to India and it was the first citrus fruit known by Europeans. However, there are different opinions about the exact period and the steps by which it was first brought from its native land (Nicolosi, 2007). The most probable is following the return of Alexander the Great from India $(\sim 300 \mathrm{BC})$ and then diffused by the Jew civilization in the Mediterranean area (Swingle and Reece, 1967). Its introduction in Spain was around the seventh century (Zaragoza, 2007). As for its genetic origin, Nicolosi et al. (2000), combining nuclear and cpDNA data, concluded that $C$. medica is a true species being the male parent in the origin of many hybrid species of Citrus, including lemons and limes. Those results have been confirmed by (García-Lor et al., 2013b; Curk et al., 2016). 
The earliest record for the mandarin (C. reticulata) was in China (2197 - 2205-BC) and in Japan (1278-1346 AD) (Nicolosi, 2007). The first European country to grow the mandarin was England, it was brought from China in 1805 (Nicolosi, 2007). Mandarins were introduced in Italy around the nineteenth century. $C$. reticulata is widely cited as the ancestor of modern cultivated mandarins (Swingle and Reece, 1976). As for its genetic origin, Wu et al. (2014) concluded that some mandarin types like 'Ponkan' and 'Willowleaf', result from interspecific introgressions of $C$. maxima (pummelo) into $C$. reticulata (wild mandarin). Later, García-Lor et al. (2015) and Curk et al. (2015) confirmed that the $C$. maxima genome was the main genome introgressed in the $C$. reticulata background of the mandarin germplasm.

Pummelo is indigenous to the Malayan and East Indian archipelagos (Nicolosi, 2007) and then spread to China, Persia, Palestine (1178 AD) and later in Europe (Spiegel-Roy and Goldschmidt, 1996). Analysis of three Chinese pummelos reported by $\mathrm{Wu}$ et al. (2014) shows that they derived from domestication of a wild sexual $C$. maxima population.

The four citrus ancestral taxa are fully sexually compatible and all the other cultivated Citrus species are considered to originate from hybridization between these ancestral species, (Nicolosi et al., 2000; García-Lor et al., 2013b; Wu et al., 2014; Curk et al., 2016).

The sweet orange (C. sinensis) is believed to have originated in Indonesia and southern China (Webber et al., 1967). It was first introduced in Spain first by Italian (1400), then Portuguese, in the middle of the 15th century (Zaragoza, 2007). Genetically, sweet orange is accepted to be an interspecific hybrid (Scora, 1975; Nicolosi et al., 2000; Wu et al., 2014). Barrett and Rhodes, (1976), Torres et al. (1978), Scora, (1988), Nicolosi et al. (2000) and Moore, (2001) proposed that sweet orange was a direct interspecific hybrid between a pummelo (C. maxima) and a mandarin (C. reticulata). Whereas recent studies (Roose et al., 2009; Garcia-Lor et al., 2012a, Xu et al., 2013 and Wu et al., 2014) indicated that $C$. sinensis resulted from a backcross 1 (BC1) [(C. maxima $\mathrm{x} C$. reticulata) x $C$. reticulata]. No more sexual events contributed to the diversification of sweet oranges and moderns orange cultivars share the same genomic organization with little sequences variation (Wu et al., 2014).

The sour orange (C. aurantium) is believed to be native to South-east Asia, possibly India (Nicolosi, 2007). The Arab traders introduced the sour orange in Spain towards the fifth and sixth centuries (Zaragoza, 2007). Molecular markers analysis showed that sour orange is a direct hybrid between a pummelo (C. maxima) seed parent and a wild mandarin (C. reticulata) pollen parent (Wu et al., 2014; Curk et al., 2015).

The exact area of the origin of the lemon ( $C$. limon) is still uncertain. Tolkowsky, (1938) suggested that the lemon is native to India while Webber et al. (1967) consider southern China and probably Upper Burma to be the native origin of the lemon. The same references affirmed that the lemon had been introduced by the Arabs in North Africa and Spain by 1048-1075 AD (Zaragoza, 2007). Molecular analyses indicate that this species resulted from direct hybridization between $C$. aurantium (sour orange) as the female parent and C. medica (citron) as the male parent (Nicolosi et al., 2000; Froelicher et al., 2011; García-Lor et al., 2013b; Curk et al., 2016). 
The origin of $C$. aurantifolia is uncertain, but Nicolosi, (2007) proposed that it is native of the Malaysian region of south-western Asia. Molecular data proved that it is a direct hybrid between $C$. micrantha as female parent and $C$. medica as male parent (Scora, 1975; Nicolosi et al., 2000; Ollitrault et al., 2012b; Garcia-Lor et al., 2013b; Curk et al., 2016).

Lime is one of the few citrus species with spontaneous polyploid germplasm. The triploid lime 'Tahiti' ( $C$. latifolia) is thought to be a hybrid between a haploid ovule of $C$. limon and a diploid gamete of $C$. aurantifolia, whereas 'Tanepao' ( $C$. aurantifolia) triploid genotypes result from a backcross between a diploid ovule of $C$. aurantifolia and C. medica (Curk et al. 2016).

Tetraploid 'Giant Key' lime, classified as C. aurantifolia by Tanaka (1961), is a spontaneous tetraploid selected in a seedling population of the diploid 'Key' lime ('Mexican' lime type) (Curk et al. 2016).

Grapefruit ( $C$. paradisi) is a very close species to $C$. maxima and could result from a spontaneous cross between $C$. maxima and $C$. sinensis hybrid produced in the Barbados island (Barrett and Rhodes, 1976; Scora et al., 1982; de Moraes et al., 2007; Ollitrault et al., 2012a). Its initial cultivation in Spain occurred in the first half of the 20th century (Herrero et al., 1996).

\section{REPRODUCTIVE BIOLOGY}

The citrus flower is perfect containing both female and male sex organs. The structure of the mature flower consists in a pistil in the center of each flower surrounded by, 2040 stamens, depending on the species (Figure1a).

Citrus fruit is a modified berry (hesperidium) originates as a consequence of single ovary growth (Figure 1b,c,d). It consists of 8-16 carpels clustered around the floral axis. The carpels form locules, or segments that contain vesicles (juice sacs) and seeds. The pericarp is divided into exocarp (flavedo) and mesocarp (albedo).

Apomixis is defined as natural replacement of normal sexual reproduction by asexual reproduction, which yields offspring that are genetically identical to the mother plant (Wang et al., 2017). Although three mechanisms of apomixis have been described in plants, the sporophytic adventitious embryony is defined as the mechanism leading to apomixis in citrus (Aleza et al., 2010c). It consists in embryos development initiation directly from the nucellar cells surrounding the embryo sac containing a developing zygotic embryo (Kobayashi et al., 1981; Aleza et al., 2010c). With the exception of citrons, pummelos and clementines cultivars and some mandarin hybrids, the rest of citrus genotypes are apomictic (Aleza et al., 2010c). Recently, Wang et al. (2017) identified an insertion of miniature inverted-repeat transposable element in the promoter region of CitRWP gene (one of the 11 candidate genes for apomixis expressed at higher levels in ovules of polyembryonic genotypes) that co-segregates with apomictic seeds. Apomixis allows the conservation of many of the spontaneous mutations and the development of uniform progeny maintaining the characteristics of the mother plant. It is a key character for conform multiplication of rootstocks by seedlings (Cameron and Frost, 1968).

Two types of seeds are distinguishable in citrus depending in the number of embryos, monoembryonic seeds produced by non-apomictic citrus genotypes and polyembryonic 
seeds developed by apomictic citrus genotypes. Monoembryonic seeds contain a single embryo of sexual origin, and polyembryonic ones contain an embryo of sexual origin and one or more nucellar embryos. The number of embryos per seed varies greatly depending on the genotype (Frost and Soost, 1968). In seeds of citrus apomictic genotypes, formation of the nucellar embryos can be initiated before fertilization and competition between the zygotic and nucellar embryos often results in the failure of the development of the zygotic one (Frost and Soost, 1968; Wakana and Uemoto, 1988; Koltunow, 1993). This characteristic can be a problem when apomictic genotypes are used as female parents in sexual hybridization. In this context, molecular marker techniques allow the differentiation between zygotic and nucellar seedlings and they have been developed and introduced within citrus breeding programs (Luro et al., 1995; Ruiz et al., 2000; Aleza et al., 2011). Nevertheless at practical level it is very difficult to recover large population of hybrids using apomictic genotypes as female parents.

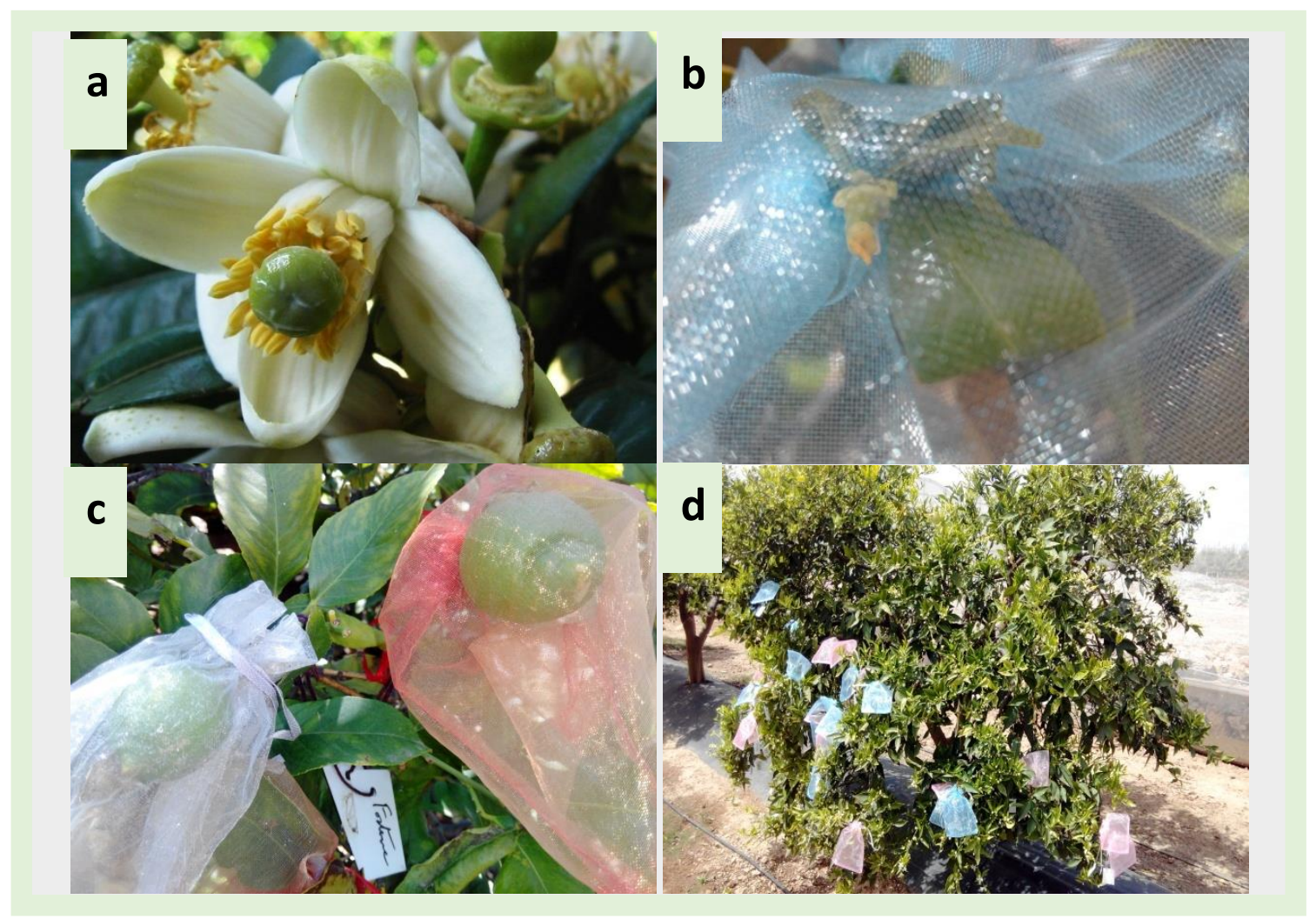

Figure 1. Citrus (a) 'Pineapple' flower, (b) 'Mexican' lime pollinated flower and (c;d) fruit set in 'Eureka Frost' lemon and tetraploid C. clementina respectively $(\mathrm{C}$ H. RouissIVIA.

Self-incompatibility is a genetically controlled mechanism by which the genotypes do not produce seeds when they are self-pollinated. Soost (1969) has shown that gametophytic self-incompatibility is the mechanism involved in citrus, which stops the development of the pollen tube in the upper or middle part of the stigma. Nearly all the pummelos, grapefruits and lemons, some mandarins, and several natural or artificial hybrids are self-incompatible (Hearn, 1969). Caruso et al. (2012) identified candidate genes involved in self-incompatibility. They suggested that expression of some nonhomologous genes located in a restricted genome region could lead to selfcompatibility. 


\section{MAIN BIOTIC AND ABIOTIC STRESS IN CITRUS}

Citrus production is affected by both biotic and abiotic stresses that can severely influence fruit quality and production. In addition, Syvertsen and Levy, (2005) described interactions between both stresses that almost have synergistic effects on citrus.

\section{IV.1. Biotic stress}

Although several biotic stress agents are described, six major biotic stresses are considered as threats to the modern citrus industry.

Citrus greening also known as Huanglongbing (HLB) is caused by three uncultured species of $\alpha$-Proteobacteria, Candidatus Liberibacter asiaticus, $\mathrm{Ca}$. L. americanus, and $\mathrm{Ca}$. L. africanus. Two insect vectors are responsible for the spread of the disease: the African citrus psyllid, Trioza erytreae and the Asian citrus psyllid, Diaphorina citri (Bové, 2014; Duran-Vila et al., 2014). This disease is present in Asia, South Africa, Brazil and USA and is commonly regarded as the most severe and devastating disease of citrus (Batool, 2007; Gottwald et al., 2007; Tatineni, 2008; Shokrollah, 2010). HLB negatively alters fruit quality and production; it makes fruits unsuitable for juice and fresh market (Bassanezi, 2009; Dagulo, 2010). In USA, the most critical situation is in Florida, where citrus growers are suffering a severe crisis since the identification of the disease in 2005. It caused a loss of $30 \%$ from total citrus cultivated superficies in Florida (USDA, 2016) especially in oranges were it destroyed already 20 million orange trees $(25 \%)$ and caused a $67.4 \%$ decrease of orange production from 2007-08 to 201516 seasons (Monzó and Stansly, 2017). The African citrus psyllid, is already present in Spain, in Galicia (Monzó et al., 2015) and the Canary islands (Duran-Vila et al., 2014). However, the citrus greening disease has not been detected yet.

Citrus canker, caused by the bacterium Xanthomonas citri pv. citri, is a very important disease in most tropical and subtropical areas where rainfall and warm temperatures are frequent during periods of shoot emergence and early fruit development. Infection can cause defoliation, shoot dieback, and fruit drop (Gottwald et al., 2002). It is present in USA, China, Brasil, Uruguay, Japan, Malaysia and Paraguay (EPPO, 2017). Some areas of the world have eradicated citrus canker like Australia and New Zealand, while the Mediteterranean area remains a free of the disease.

Alternaria Brown Spot (ABS), caused by the fungus Alternaria alternata pv. citri, is a major problem for some susceptible mandarin cultivars that induces necrotic brown lesions in fruits, leaves and shoots. The young leaves are very sensitive to the disease, and the appearance of necrotic areas on the leaves is frequent (Akimitsu et al., 2003). The affected fruits present necrotic depressions of variable size and although these lesions only affect the cortex, they commercially depreciate the fruit for fresh consumption (Vicent et al., 2000). This fungus has been detected in all citrus growing areas (Vicent et al., 2000; Timmer et al., 2003; Golmohammadi et al., 2006; Wang et al., 2010) and represents a serious problem in Spain. In fact susceptible cultivars to ABS like 'Fortune', 'Nova' and 'Murcott' mandarins, have been replaced or top-grafted by resistant cultivars. Cuenca et al. $(2013 ; 2016)$ demonstrated that the resistance to $\mathrm{ABS}$ is conferred by a recessive locus located within $366 \mathrm{~kb}$ region near the centromere of chromosome III. 
Citrus Variegated Chlorosis (CVC) symptoms were first observed in, 1984 in Argentina, but not recognized to be CVC until the disease had been characterized in Brazil (He et al., 2000). It is caused by the bacteria Xylella fastidiosa subsp. pauca, (Almeida et al., 2008). Spain remains a free region however, CVC is producing important damage in Brazil (Ollitrault and Navarro, 2012) being sweet orange varieties more susceptible than limes and grapefruits (Brlansky et al., 2002).

Citrus black spot, caused by Phyllosticta citricarpa, (McAlpine) was first described by 1895 in Australia (Carstens et al., 2017). The disease causes external blemishes on the rind which make the fruit unsuitable for the fresh market (Martínez-Minaya et al., 2015). All commercial varieties of sweet orange, mandarin, lemon and grapefruit are susceptible to the disease (Kotzé, 2000; Martínez-Minaya et al., 2015). The pathogen is currently present in the main citrus-growing regions of southern and central Africa, South America and Asia (Kiely, 1948; Kotzé, 2000) however, the Mediterranean Basin is free of the disease (Carstens et al., 2017).

Citrus tristeza virus, is present in most citrus areas, including the Mediterranean countries, usually inducing the quick decline if the used rootstock is sour orange, which is highly susceptible to the decline (Moreno et al., 2008). This decline is associated with a phloem necrosis which blocks translocation of carbohydrates to the root system (Yokomi, 2009). Tristeza virus only infects phloem-associated tissues of species of the genera Citrus and Fortunella within the family Rutaceae (Bar-Joseph et al., 1989). Tristeza has spurred the use of tolerant rootstocks, Poncirus hybrids (Citrange, Citrumelo) to replace sour orange.

\section{IV.2. Abiotic stress}

Abiotic stress agents significantly limit citrus production in many areas worldwide. Drought, salinity and soil alkalinity are a major factors reducing citrus production among the world (Álvarez-Fernández et al., 2002; Romero et al., 2006; Ollitrault and Navarro, 2012; Ruiz et al., 2016). The rootstock choice is critical to limit the impact of most abiotic stress.

Drought is considered as a principal factor that limits global citrus production, and its impact depends on the cultivar and rootstock. Citrus can sustain certain levels of water deficit stress (Romero et al., 2006). Drought in citrus trees affects several aspects of plant physiology, such as gas exchanges, hormone relations and mainly water relations (Gomes et al., 2004). Furthermore, it reduces growth and metabolism, leading to a decrease in fruit yield and quality (Gómez-Cadenas et al., 1998; Arbona et al., 2005).

The impact of salinity is critical for citrus, given the preferential accumulation of salts in the aerial part, which may lead to permanent damage of the plantations. The range of salt concentrations tolerated by citrus varies greatly from species to species and citrus are sensitive to specific ions, mainly $\mathrm{Cl}^{-}$(Maas, 1992; Bañuls et al., 1997). Recently, doubled diploids (DD) selected from different citrus rootstocks, have been studied to evaluate their tolerance to salinity compared to their diploid parent. Ruiz et al. (2016) indicated that the lower transpiration rate and thus lower $\mathrm{Cl}$ - accumulation in the aerial part are involved in the enhanced salinity tolerance of the tetraploid rootstocks. 
Soil alkalinity affects many areas especially in the Mediterranean basin restricting the use of sensitive rootstocks like $P$. trifoliata. Alkaline $\mathrm{pH}$ can induce iron deficiency in plants, limiting their absorption and transport (Coulombe et al., 1984; White and Robson, 1990). For this reason, the technique commonly used to avoid iron chlorosis, is to apply to the soil synthetic ferric chelates that are most effective under alkaline conditions (Álvarez-Fernández et al., 2002).

\section{MAIN OBJECTIVES OF CITRUS BREEDING PROGRAMS}

Systematic oriented breeding programs first began in Florida in 1893 with Swingle and Webber (Davies and Albrigo, 1994). The modern citrus industry is based on grafted plants, with the scion cultivar budded on a rootstock (Khan and Kender, 2007; Ollitrault and Navarro, 2012). So breeders have to keep in mind that scion and rootstock cannot be breaded independently, since many factors can affect the final product such as graft compatibility, fruit quality and productivity (Gmitter et al., 2009; Navarro et al., 2015). Fruit quality, productivity, maturing time and tolerance to diseases are the main objectives of scion breeding programs. For the rootstock, breeders are looking mainly for resistance to soil pathogens and viruses diseases and adaptation to abiotic stress (water deficit, salinity, calcareous soils, etc) (Khan and Kender, 2007; Ollitrault and Navarro, 2012).

\section{V.1. Main objectives of scion breeding programs}

For any breeding program, the quality of the final product is the essential criteria. The definition of organoleptic quality can vary according to the consumers. Citrus breeders must therefore endeavor to develop a wide range of varieties likely to meet these diverse demands.

For fresh fruit market, the challenges of new citrus varieties for the next future will be to recover seedless cultivars with high nutritional qualities and health-promoting effects (Ollitrault et al., 2008). Citrus fruits have a multitude of health promoting properties and research has made significant contributions in connecting specific health benefits to a group of secondary metabolites (Butelli et al., 2012; 2017). Otherwise, it 's important to obtain cultivars producing fruits during the whole harvesting season to avoid the need for conservation and in order to fulfill the demand in optimal conditions (Ollitrault et al., 2008; Sdiri et al., 2012; Aleza, 2015).

Resistance to abiotic stress for scion breeding is also a main goal for many breeding programs (Nicotra, 2001). Some diseases cause considerable damages in orchards. Huanglongbing in Asia, South Africa and recently in Brazil and Florida, citrus canker in most tropical and subtropical areas, citrus variegated chlorosis and Sudden death in Brazil. Alternaria also becomes a problem for some mandarin cultivars in several countries, such as 'Fortune' and 'Nova' mandarins and 'Murcott' tangor in Spain. Ranges of varietal susceptibility have been established for most of these diseases and tolerant parents are selected in some breeding programs. (Boscariol et al., 2006; Ollitrault and Navarro, 2012; Cuenca et al., 2013b; 2016). 


\section{V.2. Main objectives of rootstocks breeding programs}

The need for new rootstocks is of primary concern as they affect all aspects of fruit production and quality (Castle, 2010; Grosser and Gmitter, 2011; Ollitrault and Navarro, 2012). The choice of rootstock breeding objectives is usually based on the specific needs for each region and production area. General considerations as disease tolerance and resistance or soil type are often decisive factors (Gmitter et al., 2009; Ollitrault and Navarro, 2012). Phytophthora and citrus tristeza virus resistance are two essential characters for citrus rootstock.

For instance, for HLB, no ultimate resistance or tolerance has been described in citrus. However, Castle et al. (2015) described the 'Economical tolerance' as range of possibilities to breed economic tolerant rootstocks. Grosser and Gmitter, (2014) obtained and are evaluating various tetraploid rootstocks for HLB resistance in Florida. Finally, relative genera, like Microcitrus and Eremocitrus were reported to be tolerant (Ramadugu et al., 2016). Those genera are compatible with the Citrus genera, so they can be used in future breeding programs.

Otherwise, interactions between different types of stress were reported. Salinity stress can inhibit plant defense mechanism against Phytophthora (Afek and Sztejnberg, 1993) and decrease root regeneration under pathogen pressure (Syvertsen and Levy, 2005). The development of new rootstocks combining tolerance to biotic (tristeza, Phytophthora spp) and abiotic (salinity and alkaline soils) stresses to provide high quality fruits is a major objective for many rootstocks breeding programs.

Other objective for rootstock breeding program is the tree size control for high-density plantings. It was observed that tetraploid rootstocks provided some level of size control (Batra, 1952; Beakbane, 1967). Their potential utility as citrus rootstocks has been suggested in many studies (Cameron and Frost, 1968; Lee, 1988; 1990; Spiegel-Roy and Goldschmidt, 1996; Grosser and Gmitter, 2014) because it allows efficient production and reducing costs (Grosser et al., 2007). Some programs to improve citrus rootstocks at the tetraploid level have been initiated worldwide (Ollitrault et al., 2008; Grosser and Gmitter, 2011; Dambier et al., 2011; Ruiz et al., 2016).

\section{CITRUS BREEDING: STRATEGIES, TOOLS AND MAIN RESULTS}

Several serious obstacles exist and complicate the conventional sexual citrus breeding, as the complex reproductive biology (Navarro, 2005; Gmitter et al., 2009; Navarro et al., 2015), high heterozygosity (Ollitrault and Faure, 1992; Gmitter et al., 2009; Navarro et al., 2015), pollen and ovule sterility, incompatibility and long juvenile period (Khan and Kender, 2007). The main strategies used for citrus breeding are identification and clonal selection of spontaneous mutation observed in orchards, induced mutations in elite genotypes, or sexual hybridizations taking advantage of biotechnology tools developed in citrus to solve the problems found in conventional breeding.

\section{VI.1. Spontaneous mutations}

It is the oldest and the most efficient breeding method since most of the varieties cultivated worldwide arose from this process (Aleza, 2015). Spontaneous mutation are 
identified on adult material, so the obtained genotypes do not display juvenile characteristics (Ollitrault and Navarro, 2012; Aleza, 2015). Additionally, those new cultivars usually have the general characteristics of the parent, with specific change in traits concerning harvesting period, size or fruit color.

The frequency of spontaneous mutations in the field is relatively high and easy to find, especially if the mutation affects fruit morphological characteristics. (Vardi et al., 2008; Ollitrault and Navarro, 2012; Henrique et al., 2016).

In the Mediterranean area, mainly in Spain, many new clementine varieties have been selected, for their harvesting period and fruit size and color. Similar results have been obtained for Satsuma mandarins in Japan and sweet oranges in Australia and South Africa (Aleza, 2015).

\section{VI.2. Induced mutagenesis}

Since 1935, various mutagenesis agents have been used to obtain new cultivars, being gamma irradiation the most common method (Aleza, 2015). The main advantage of this method is the preservation of the main genetic background of the initial cultivar and the modification of only one or a small number of traits. Other plus of this technology is its simplicity (it is not necessary previous knowledge on gene control traits), rapidity (resulting trees will not display juvenile phase) and inexpensiveness. The main disadvantages are the large populations needed to find desirable stable mutations and the frequent chimeric status of the mutations. 'Star Ruby' grapefruit was the first commercial cultivar obtained by irradiating seeds of 'Hudson' grapefruit; later, 'Rio Red' grapefruit was obtained by irradiation of 'Ruby Red' grapefruit (Hensz, 1971). This technique is mainly used for obtaining diploid seedless genotypes and there are many examples of recently released seedless cultivars like 'Nulessin' and 'Nero' clementines from 'Clemenules' clementine, 'Mor', 'Moria', Murta' and 'Murina' from 'Murcott' tangor, 'Orri' from 'Orah' mandarin, 'Tango' from 'Nadorcott' tangor, 'Moncalina' from 'Moncada' mandarin, 'DaisySL' from 'Daisy' mandarin, 'Mandanova' from 'Nova' mandarin and 'FairchildSL' from 'Fairchild' mandarin.

\section{VI.3. Sexual breeding}

Diploidy is the general rule in Citrus and its related genera, with a basic chromosome number $\mathrm{x}=9$ (Krug, 1943). However, some triploid and tetraploid genotypes have been early detected in citrus germplasm or seedlings (Longley, 1925; Lapin, 1937; Iwasaki, 1943). Conventional breeding in citrus has important limitations due to the complex reproductive biology of these species. Most genotypes are apomictic, and the development of zygotic embryos is hampered by the presence of the nucellar embryos. So in practice apomictic genotypes are avoided as female parents in most breeding programs. Furthermore, male and female sterility, and self and cross-incompatibility are relatively common among many genotypes, which limit the possibilities to select parents for specific crosses.

Once obtained, sexual hybrids display a long juvenile period and they need to undergo a transition from the juvenile to the reproductive phase that often goes on more than six years (Krajewski and Rabe, 1995). This characteristic of the citrus juvenile plants is one of the most important constraints for citrus breeding programs. In addition, there is a lack of knowledge of the genetic mechanisms that control the main organoleptic and 
pomological traits. All this aspects complicate the breeding schemes over several generations. (Ollitrault et al., 2008; Navarro et al, 2005; 2015; Aleza, 2015).

The absence of seeds is appreciated in citrus fruits because many consumers do not accept seedy fruits. Seedlessness can contribute to the increase of some fruits quality when when seeds are hard or have a bad taste. In the case of citrus, seeds are associated with unfavorable aromatic compounds and bitterness (Ollitrault et al., 2007b). Thus, the breeding for seedless cultivars has become a major goal in many citrus breeding programs around the world either at diploid or triploid levels (Recupero et al., 2005; Ollitrault et al., 2007b; Roose and Williams, 2007; Aleza et al., 2010a,b; Cuenca et al., 2010; Navarro et al., 2015).

\section{VI.3.1. Sexual breeding for seedlessness at diploid Level}

Sexual breeding is mainly used for diversification of the main important genotypes. Most of the obtained diploid hybrids are fertile and thus seedy, which limit the use of this methodology. Moreover, sterility was managed at diploid level to obtain seedless hybrids. Indeed, most of the commonly cultivated diploid citrus species have some degree of ovule or pollen sterility (Frost, 1948). Male and female sterility may be due to different genetic factors such as, sterility genes, and chromosomal abnormalities like reciprocal translocations and inversions (Iwamasa, 1966; Iwamasa and Iwasaki, 1963; Del Bosco et al., 1999; Ollitrault et al., 2012). The strongest female sterility reported in citrus concern the 'Mukaku Kishu' mandarin (C. kinokuni hort. Ex. Tanaka) caused by an arrested seed development at early stage (Yamasaki et al., 2009).

Male sterility in 'Eureka' lemon and 'Mexican' lime is induced by chromosome aberration (Nakamura, 1943; Iwamasa and Iwasaki, 1963; Iwamasa, 1966) and reciprocal translocation is the main cause of male sterility in 'Valencia' sweet orange (Iwamasa, 1966). In satsuma and 'Encore' mandarins different genetic analysis have been performed with the objective to study the process of anther abortion. Different works have been published (Iwamasa, 1966; Nakano et al., 2001; Yamamoto et al., 2001) indicating that this male sterility is produced by a nucleo-cytoplasmic interaction and is probably controlled by more than two major nuclear genes. 'Kiyomi' tangor and 'Queen' mandarins are two hybrids with satsuma as female parent and both genotypes produce androsterile flowers.

The gametophytic self-incompatibility described in some citrus genotypes (Soost, 1969) avoids the development of pollen tube in the style of the pistil. These genotypes produce seedless fruits if growing in isolation, but if compatible cultivars are planted in the proximity seedy fruits can be produced as a consequence of their female fertility and cross-pollination. This situation occurs, for example, with clementines and other mandarin genotypes like 'Nadorcott' tangor. Despite those limitations, seedless or low seed diploid hybrids have been obtained in breeding programs with importance at commercial level in different countries, such as 'Gold Nugget' and 'Kiyomi' mandarins (Aleza, 2015).

\section{VI.3.2. Sexual breeding for seedlessness at triploid Level}

Triploid plants are generally considered an evolutionary dead-end, since they, commonly, give rise to aneuploid gametes with very low fertility (Otto and Whitton, 
2000) due to the trivalents and univalent associations that are formed during meiosis of citrus triploid hybrids (Cameron and Frost, 1968). Moreover, abortion of the megasporogenesis between the embryo-sac first divisions and the fertilized egg cell is common (Fatta del Bosco et al., 1992). For these reasons, citrus triploid hybrids are generally sterile, although they can occasionally produce fruits with very few seeds. An important exception concern the triploid $C$. aurantifolia lime ('Tanepao' type) producing seedy fruits.

Different triploid breeding program were started during the eighties and nineties of the last century with the objective to produce new high quality seedless triploid cultivars. Citrus triploid plants can be obtained by 2x x 2x (Esen and Soost, 1971; 1973a; Ollitrault et al., 2008; Aleza et al., 2010b; Cuenca et al., 2015; Navarro et al., 2015) or $2 \mathrm{x} \times 4 \mathrm{x}$ and 4x x 2x sexual hybridizations (Esen and Soost, 1973b; Cameron and Burnett, 1978; Starrantino and Recupero, 1981; Ollitrault et al., 2008; Grosser and Gmitter, 2011; Aleza et al., 2012a, b; Navarro et al., 2015). Sexual hybridization between diploid parents exploits natural events of polyploidization such as unreduced gametes, using embryo rescue and flow cytometry to select triploid hybrids (Ollitrault $e t$ al., 1996, 2007b; Aleza et al., 2010a,b). Another strategy is to cross diploid nonapomictic female parents with tetraploid male parents (Starrantino and Recupero, 1981). Such tetraploid plants can be obtained in apomictic seedlings as a consequence of the spontaneous duplication of chromosomes in nucellar cells (doubled-diploids (Aleza et al., 2011), by somatic hybridization (Grosser et al., 2000; 2010a) or by artificial chromosome doubling by colchicine or oryzalin treatments. The application of the last technique to monoembryonic parents opens the avenue to $4 \mathrm{x} x 2 \mathrm{x}$ crosses with tetraploid female parents. This strategy displays the highest efficiency for triploid hybrids production in comparison with the other two (Aleza et al., 2012b).

Several triploid hybrids recovered in breeding programs have been released worldwide. The first two selections of the IVIA (Instituto Valenciano de Investigaciones Agrarias) triploid breeding program (Navarro et al., 2015) were released in, 2008: 'Garbi' and 'Safor' mandarins (Aleza et al., 2010a; Cuenca et al., 2010). More than 600.000 plants of both mandarins have been sold in the last years (Aleza, 2015). Otherwise, 'Shasta Gold®', 'Tahoe Gold ${ }^{\circledR}$ ' and 'Yosemite Gold ${ }^{\circledR}$ ' triploid mandarins were released by the Riverside breeding program in California (Roose et al., 2002; Williams and Roose, 2004); and other triploid mandarins like 'Tacle', 'Clara', 'Mandared' and 'Mandalate' mandarins and 'Lemox' lemon were released by Istituto Sperimentale per l'Agrumicoltura di Acireale, Italy (Starrantino and Recupero, 1981; Russo et al., 2004; Recupero et al., 2005).

More details on unreduced gametes and tetraploid meiosis and resulting genetic structure of unreduced and diploid gametes are given in sections VII, Sexual and somatic citrus polyploidy.

\section{VI.3.3. Tetraploid citrus genetic pool diversification}

Scarcity of tetraploid parents represents a major limitation to create triploid hybrids from interploid crosses. Thus, several research groups are working to diversify the tetraploid gene pool by identification and selection of spontaneous tetraploids (doubleddiploids; Aleza et al., 2009b, 2011)) and somatic hybridization by protoplast fusion (Grosser et al., 2000; Ollitrault et al., 2007a; Navarro et al., 2015). 


\section{Doubled-diploids}

Doubled-diploids are obtained through two ways, either selection of spontaneous tetraploids and induction of tetraploid plants with antimitotic chemicals. Spontaneous tetraploidization seems to occur frequently in apomictic citrus genotypes. Frost and Soost, (1968) and Kobayashi et al. (1981) proposed that chromosome doubling in nucellar tissue might be the general mechanism underlying this process. It was confirmed by Aleza et al. (2011). This characteristic could be under genetic control (Barrett and Hutchison, 1978) and/or affected by environmental conditions (Hutchison and Barrett, 1981; Aleza et al., 2011).

At IVIA (Spain) and in the CIRAD (Centre de Coopération Internationale en Recherche Agronomique pour le Développement-France) breeding programs, many doubleddiploids plants have been identified analyzing a high number of seedlings by flow cytometry. The handicap of this methodology is the juvenile period displayed for the obtained plants which limit their direct use for hybridization (Navarro et al., 2015).

In non-apomictic citrus genotypes spontaneous tetraploidization does not occur. Aleza et al. (2009) established a new technique to produce autotetraploid genotypes based on in vitro shoot-tips grafting combined with colchicine or oryzalin treatment and selection of non-chimeric plants by flow cytometry. This methodology gave rise to stable non apomictic tetraploid plants of different mandarins (Aleza et al., 2009b; Navarro et al., 2015). This methodology, allows to recover plants without juvenile characters (Navarro et al., 2015) permitting consequently its use for triploid hybrids production through $4 \mathrm{x} \mathrm{x}$ $2 \mathrm{x}$ and $2 \mathrm{x} \mathrm{x} 4 \mathrm{x}$ sexual hybridizations.

\section{Sexual hybrids}

Sexual tetraploid hybrids were reported in $2 \mathrm{x}$ x 4x sexual hybridizations (Tachikawa et al., 1961; Cameron and Soost, 1969; Esen and Soost, 1972; Ollitrault et al., 2008). Esen and Soost (1972) suggested that they were originated from unreduced female gametes fertilized by diploid pollen. It was confirmed later by Aleza et al. (2012a) with molecular markers. In 4x x 2x hybridizations, Aleza et al. (2012b) displayed the production of tetraploid hybrids originated by self-pollination. However, until now, no tetraploid hybrids have been recovered in $4 \mathrm{x} x 2 \mathrm{x}$ sexual hybridizations by fertilization of diploid female gametes with unreduced male gametes.

These tetraploid hybrids are of great value for triploid cultivars and tetraploid rootstock breeding programs.

\section{Somatic hybrids}

Somatic hybridization is an important tool in citrus breeding programs (Ollitrault et al., 2008; Grosser et al., 2010; Grosser and Gmitter, 2011; Navarro et al., 2015; Aleza, 2015). Somatic hybrids can be obtained through the bind of two non-sexual cells, one from an embryonic callus and the other from a mesophyll-cell. The fusion is carried out by the use of polyethylene glycol (PEG) or by electro-fusion. In case of symmetric fusion, somatic hybrids are tetraploid plants possessing the entire genetic configuration of their parents with no recombination (Louzada et al., 1993; Ollitrault et al., 2007a; 
Grosser et al., 2010; Grosser and Gmitter, 2011; Dambier et al., 2011; Aleza et al., 2016b). One advantage of this methodology is the possibility to produce allotetraploid somatic hybrids between sexual incompatible genotypes and to produce new genetic combinations overcoming the complex citrus reproductive biology (Grosser and Gmitter, 1990; Grosser et al., 2000; Ollitrault et al., 2007a; Dambier et al., 2011; Grosser and Gmitter, 2011; Aleza et al., 2016b).

In citrus, the most important application of somatic hybridization is the production of autotetraploid and allotetraploid hybids that can be used either as rootstocks or as tetraploid parents in interploid sexual hybridizations for the production of seedless triploid cultivars (Grosser and Gmitter, 2005; Ollitrault et al., 2007a; Grosser et al., 2010).

\section{VI.4. Biotechnological tools for citrus breeding}

\section{VI.4.1. Genetic transformation}

Applications of the biotechnological techniques such as genetic engineering are useful for the genetic improvement of many of the citrus cultivars avoiding the barriers of the traditional sexual hybridization (Gmitter et al., 1992; 2009; Peña et al., 2001; 2008; Pons et al., 2011; Navarro et al., 2015). The most used methods are through Agrobacterium tumefaciens or PEG (polyethylene glycol) treatment of protoplasts (Peña et al., 2008). This methodology can open the way to the introduction of specific traits associated with a known characters into elite genotypes without altering their genetic background. Genetic engineering has been experimentally applied to an increasing number of traits to try inducing resistance to the CTV virus (Soneji et al., 2007; Soler et al., 2012), tolerance to HLB disease (Dutt et al., 2016) and repellency to its psyllid vector (Alquézar et al., 2017), and to enhance tolerance to salinity (Cervera et al., 2000) or for reproductive biology investigation purposes (Pons et al., 2011). In addition, genetic transformation has been used in attempts for the introgression of seedlessness to some elite genotypes as 'Mexican' lime (Koltunow et al., 2000) and 'Ponkan' and 'Valencia' sweet orange (Li et al., 2002; 2003).

\section{VI.4.2. Genome Editing}

Biotechnological tools are developed for genome engineering through edition and they are expected to take place in all fields of future plant breeding. It is a set of molecular tools for cells, tissues and whole organism editing (Barrangou and Doudna, 2016). Clustered regularly interspaced short palindromic repeat (CRISPR)/Cas9/single guide RNA (sgRNA) have been already successfully used to obtain genetically modified rice, wheat, Arabidopsis, tobacco and sorghum (Nekrasov et al., 2013; Shan et al., 2013). In citrus, genetic modification has been used either for general objectives like gene function detection (Jia and Wang, 2014) or for specific objectives as citrus canker resistance (Peng et al., 2017).

\section{VI.4.3. Viral Vectors}

Plant virus vectors have been used for both expression of foreign genes (Gleba et al., 2007) and suppression of endogenous target genes by virus-induced gene silencing (VIGS) in the infected plants (Senthil-Kumar and Mysore, 2011). Velázquez et al. 
(2016) developed a viral vector to promote the transition from vegetative to the reproductive phase in juvenile citrus plants by expression of Arabidopsis thaliana or citrus FLOWERING LOCUS T (FT) gene based on Citrus leaf blotch virus vector. Triploid citrus hybrids were inoculated with this viral vector. All of them flowered in one year from the inoculation date (Aleza et al., 2016c) providing helpful tool to speed up genetic studies and breeding programs.

\section{VI.4.4. Genetic and genomic resources}

Molecular markers are specific DNA sequence transmitted by the standard laws of inheritance from one generation to the next. Numerous forms of molecular markers have been developed for Citrus. Isozymes markers (Torres et al., 1978; 1982; Roose, 1988), Random Amplified Polymorphic DNA [RAPDs; (Luro et al., 1994)], Sequence Characterized Amplified Regions [SCARs; (Nicolosi et al., 2000)], Restriction Fragment Length Polymorphism [RFLPs; (Federici et al., 1998)], Intersimple Sequence Repeat [ISSRs, (Fang et al., 1997)], Amplified Fragment Length Polymorphism (AFLPs; (Liang et al., 2007; Pang et al., 2007) and Cleaved Amplified Polymorphic Sequences (CAPs) from ESTs (Lotfy et al., 2003) were used mainly for diversity studies.

Since Kijas et al. (1995), SSRs or microsatellites markers have been introduced in Citrus genetic studies. They are often helpful for phylogenetic studies (Luro et al., 2001; Garcia-Lor et al., 2012; Garcia-Lor et al., 2013b), somatic hybrids characterization (Aleza et al., 2016b), discrimination between zygotic and nucellar seedlings (Ruiz et al., 2000; Ruiz and Asins, 2003), control of the origin of plants obtained by induced gynogenesis (Froelicher et al., 2007), molecular characterization of triploid cultivars (Cuenca et al., 2010), the analysis of the origin of unreduced gametes (Luro et al., 2004; Chen et al., 2008; Cuenca et al., 2011; Aleza et al., 2016a), mapping (Ollitrault et al., 2012a), and marker assisted selection in breeding (Cuenca et al., 2016). The homoplasic phenomena (identical allelic size arising from independent genetic events) observed by Barkley et al. (2009) can limit the use of those markers for phylogenetic studies.

The availability of large set of sequencing data has opened the way for SNP (Single Nucleotide Polymorphism) marker development (García-Lor et al., 2012a; Ollitrault et al., 2012a; 2012b; García-Lor et al., 2013b). SNP markers have been used for genetic diversity studies (Chen and Gmitter, 2013; Cuenca et al., 2013a; Garcia-Lor et al., 2013a and b, Curck et al., 2016), marker assisted selection (MAS) for resistance against Alternaria alternata (Cuenca et al., 2013b, 2016), discrimination of zygotic and nucellar plants in seedlings (Zhu et al., 2013) and mapping (Ollitrault et al., 2012a).

At polyploid level, SSR markers have been used in citrus to infer the genetic origin and allelic configurations of triploid and teraploid hybrids using markers with total differentiation between the parents. Indeed, conclusive results can be obtained using only one marker. Otherwise, in case of shared alleles between parents for a given marker, the allele dosage of the obtained triploid and tetraploid hybrids could be estimated by the MacPr method (REF) validated in citrus by Cuenca et al. (2011). SNPs are also very useful for the identification of allele doses in heterozygous triploid and tetraploid hybrids as described by Cuenca et al. (2013a). SNP genotyping could be performed using the KASPar technique. This methodology allows the identification of 
allele doses in heterozygous triploid and tetraploid hybrids via the relative allele signals (Cuenca et al., 2013a).

Ollitrault et al. (2012a) published the clementine reference genetic map and later, Aleza et al. (2015) located the centromere positions for all LGs. This genetic map has been used to enable the chromosome assembly of the reference whole genome citrus sequence (Wu et al., 2014), that used a haploid clementine for sequencing (Aleza et al., 2009a).

$\mathrm{Xu}$ et al. (2013) sequenced and assembled the dihaploid genome of sweet orange. Recently Wang et al. (2017) published the draft genomes of a citrus relative species, Atalantia buxifolia, $C$. ichangensis, $C$. medica and C. maxima (Wang et al., 2017). The availability of these whole genome sequences provides a valuable genomic resource for citrus genetics and breeding improvement.

\section{SEXUAL AND SOMATIC CITRUS POLYPLOIDY}

Polyploidy is a very common phenomenon in plants, particularly in angiosperms, where 60-70\% of the species have a polyploid ancestor (Grant, 1981; Van de Peer et al., 2009). Even the first polyploid was discovered over a century ago (Strasburger, 1910), the genetic and evolutionary implications of polyploidy are still being studied and discussed (De Storme and Geelen, 2013b). Many cultivated species are polyploid; potato varieties include triploids, tetraploids and pentaploids. Oats are hexaploid, wheat species are tetraploid and hexaploid, banana is triploid and strawberry species and hybrids can be diploid, tetraploid, pentaploid, hexaploid, heptaploid, octoploid, or decaploid. Polyploidy also exists in wild species such as oak and bluegrass (Wendel, 2000). Several anatomic and physiologic characters that advantage polyploidy species against stress and adaptation to environmental conditions were attributed to polyploidy (Warner and Edwards, 1989; 1993; Li et al., 1996; Ramsey, 2011; Manzaneda et al., 2012).

For breeding, there are many opportunities for exploitation of polyploidy as a valuable tool (Ortiz, 1997; Ollitrault et al., 2008; Cuenca et al., 2015). The two main mechanisms of polyploid formation are somatic doubling of chromosome set (somatic polyploidization) and meiotic nuclear restitution leading to unreduced gamete production (sexual polyploidization).

\section{VII.1. Unreduced gametes}

Unreduced gametes formation is widespread across numerous eukaryotic taxa, including yeasts, plants, insects, amphibians, reptiles, and fish (Dowling and secor, 1997; Brownfield and Köhler, 2011; Mable et al., 2011; Albertin and Marullo, 2012). Indeed, several studies suggested that the majority of polyploidization events in both plants and animals have been produced from unreduced gametes (Ramsey and Schemske, 1998; Husband, 2004; Ramsey, 2007). Environmental stress often promote the formation of unreduced gametes, suggesting that these may facilitate polyploid speciation in response to changing environments, thus, it can be considered as a mechanism for evolutionary speciation (Mason and Pires, 2015). 
The normal meiosis involves DNA replication followed by two rounds of chromosome division to produce cells with half the chromosome number of the mother cell. In the first meiotic division, the homologous chromosomes are separated, so it is called a reductional division. For the second meiotic division, it involves the separation of sister chromatids and referred as an equational division. Unreduced gametes arise through meiotic defects so called meiotic nuclear restitution. It was described for the first time by Rosenberg, (1927) and up to seven major mechanisms of unreduced gamete formation have been cytogenetically characterized: pre-meiotic doubling (PRD); postmeiotic doubling (PMD); first-division restitution (FDR); chromosome replication during the meiotic interphase; second-division restitution (SDR); indeterminate meiotic restitution and apospory (Peloquin et al., 1989; Lim et al., 2001; Dewitte et al., 2012). Although $2 \mathrm{n}$ gamete formation through pre-meiotic genome doubling is rare in plants, it has been observed in Solanum lycopersicum by De Storme and Geelen, (2013b). The post-meiotic restitution is characterized by the formation of fully homozygous $2 \mathrm{n}$ gametes after an extra round of genome duplication. This mechanism was observed in Solanum tuberosum (Bastiaanssen et al., 1998) in some Rubus species (Dowrick, 1966) and in Alstroemeria (Ramanna and Jacobsen, 2003).

FDR and SDR mechanisms are considered the principal mechanisms of $2 \mathrm{n}$ gamete formation (Bretagnolle and Thompson, 1995; Tavoletti et al., 1996; Cai and Xu, 2007). These mechanisms arise through meiotic defects. If an equational mitosis of all chromosomes occurs in the first division instead of a reductional mitosis, an FDR $2 \mathrm{n}$ gamete will be produced. As a result, the non-sister chromatids are included in the same gamete (Gallais, 2003; Park et al., 2007; Cuenca et al., 2011). Alternatively, if the first mitosis occurs normally, but an omission of the second meiotic division occurs, an SDR $2 \mathrm{n}$ gamete will be produced with sister chromatids included in the same gamete (Gallais, 2003; Park et al., 2007; Cuenca et al., 2011). The cytological processes leading to meiotic restitution can be divided in three classes: alterations in spindle biogenesis and polarity, cytokinetic defects and complete omission of a meiotic cell division (De Storme and Geelen, 2013a).

The identification of the mechanisms underlying $2 \mathrm{n}$ gametes formation is complex. Cytological techniques have been used initially to determine the mechanism of $2 \mathrm{n}$ gamete formation by genomic in situ hybridization-GISH or/and fluorescent in situ hybridization-FISH (Lim et al., 2001; Crespel and Gudin, 2003; Dewitte et al., 2012). However, the small and indistinguishable citrus chromosomes and the small frequency of unreduced gametes represented a major constrain for these techniques in citrus (Barba Gonzalez et al., 2005; Jaskani et al., 2007). In contrast, molecular marker analysis have been proved as a very helpful tool to estimate the heterozygosity restitution in the unreduced gametes in polyploid progenies and paves the way for the identification of mechanism underlying 2n gametes formation (Barone et al., 1995; Vorsa and Rowland, 1997; Bastiaanssen et al., 1998; Barcaccia et al., 2003; Luro et al., 2004; Chen et al., 2008; Hayashi et al., 2009).

The unreduced gametes frequency is under genotype and environmental control. The genetic control of $2 \mathrm{n}$ gamete formation has been observed in peach, Medicago sativa, Trifolium pratense and S. tuberosum (Dermen, 1938; Mok and Peloquin, 1975; Parrott and Smith, 1986; Tavoletti et al., 1996). In addition, it was observed that interspecific and intergeneric hybrids produce unreduced gametes more frequently than their parents (Ramsey and Schemske, 1998) supporting the idea that the underlying cytological 
anomalies mentioned above are regulated by a monogenic allele (Bretagnolle and Thompson, 1995; Ortiz, 1997).

Bretagnolle and Thompson, (1995) added that the unreduced gamete formation is sex specific leading to probably a different mechanism for each sex. d Erfurth et al. (2008) identified the protein AtPS1 from A. thaliana (PARALLEL SPINDLES 1) that induces a restitution of male meiosis (up to 65\%), and not in the female. Recent studies have revealed a genetic background for the pre-meiotic genome doubling. Two proteins have been found to be involved in meiotic ploidy control: the 40S ribosomal protein (rp) S6 kinases S6K1 and S6K2 (De Storme and Geelen, 2013a).

The different mechanisms of $2 \mathrm{n}$ gamete formation have different genetic consequences and particulary affects the transmission of the parental heterozygosity in relation to centromere distance. FDR 2n gametes contain non-sister chromatids, which in the absence of crossover maintain the parental heterozygosity. When crossing over occurs, the parental heterozygosity restitution (PHR) rates vary from $100 \%$ for loci close to the centromere to $60-70 \%$ for loci far from the centromere, depending on the level of chromosome interference (Cuenca et al., 2011). For SDR, the 2n gametes contain two sister chromatids, which reduces the parental heterozygosity level (Bastiaanssen et al., 1998; Cuenca et al., 2011; De Storme and Geelen, 2013b). When crossing over occurs, the PHR rate varies from $0 \%$ for loci close to the centromere to $60-75 \%$ for loci far from the centromere, depending on the level of chromosome interference (Cuenca et al., 2011).

Pre-meiotic genome doubling produces $2 \mathrm{n}$ gametes equivalent to the meiosis of doubled diploid genotypes. Therefore, PHR depends mainly on the chromosomal preferential pairing rate (Stift et al., 2008), which should vary between $66 \%$ for fully tetrasomic meiosis to $100 \%$ for fully disomic meiosis. Little variation can occur along the chromosome due to double reduction events. In the case of post-meiotic doubling, haploid gametes undergo an extra round of genome duplication, leading to the formation of fully homozygous 2n gametes (Bastiaanssen et al., 1998; Ramanna and Jacobsen, 2003; De Storme and Geelen, 2013b; Cuenca et al., 2015). Thus, 100\% homozygosity for all loci is expected among the $2 \mathrm{n}$ gametes (Ramanna and Jacobsen, 2003). SDR can also produce $100 \%$ homozygosity for centromeric markers, but not for telomeric ones (Cuenca et al., 2011). Therefore, in order to distinguish between both mechanisms, Cuenca et al. (2015) genotyped telomeric loci to determine whether diploid gametes fully homozygous for centromeric markers resulted from post-meiotic doubling or SDR. Alternatively, Bastiaanssen et al. (1998) obtained hybrids originated from fully homozygous $2 \mathrm{n}$ female gametes, they used RFLP markers to prove the existence of recombination of homozygous alleles originated from its ancestor's parents for the same linkage group (LG), and thus they concluded that it originated from postmeiotic genome doubling.

Molecular marker analysis is used for the estimation of parental PHR through unreduced gametes in polyploid progenies (Barone et al., 1995; Vorsa and Rowland, 1997; Luro et al., 2004; Bastiaanssen et al., 1998; Cuenca et al., 2011; 2015). Most of the previously developed methodologies are based on the genetic analysis of a high number of random molecular markers. Markers with PHR lower than 50\% indicate that the progeny was originated by SDR (Park et al., 2007) whereas with PHR over 50\%, for 
all analyzed markers, no definitive conclusion between SDR or FDR can be obtained without previous knowledge of their genetic distance to the centromere. Tavoletti et al., (1996) developed a multilocus maximum-likelihood method of half-tetrad analysis (HTA) to estimate the relative frequencies of FDR and SDR that was also useful for mapping centromere position. In citrus, taking advantage of the centromeres location (Aleza et al., 2015) in the reference genetic map (Ollitrault et al., 2012a), Cuenca et al. (2015) developed a maximum-likelihood methodology to identify the unreduced gamete formation mechanism both at the population and individual levels using independent centromeric markers.

Comparing to other species, citrus produce a high percentage of unreduced gametes. Aleza et al. (2010a) and Cuenca et al. (2011) reported that several citrus species produce unreduced gamete in frequencies ranging from $1 \%$ to over, $20 \%$. As a consequence, triploid plants $(2 \mathrm{n}=3 \mathrm{x}=27)$ can be obtained through unreduced gametes and it has been used in several plant-breeding programs for the development of seedless commercial citrus varieties (Ollitrault et al., 1996; 2008; Navarro et al., 2005;2015; Aleza et al., 2010a,b; 2011; 2012a,b).

Untill recently, only two mechanisms have been detected in citrus, FDR and SDR, and many published papers affirmed that SDR mechanism is the main mechanism of $2 \mathrm{n}$ megagametophytes in citrus (Esen et al., 1979; Luro et al., 2000; Cuenca et al., 2011, 2015; Aleza et al., 2016a). Chen et al. (2008) proposed FDR mechanism as the principal mechanism for the $2 \mathrm{n}$ eggs formation in sweet orange and Ferrante et al. (2010) in lemon. However, their results may be questionable because they were based on the analysis of a few numbers of individuals, with few markers and without previous knowledge of centromere location. Later, Cuenca et al. (2015) revealed that FDR-2n gametes were implicated in three over 543 triploid hybrids analyzed $(0.6 \%)$, one in 'Ellendale' tangor and two in 'Fortune' mandarin.

A few cases of unreduced pollen gametes have been reported in citrus although that the the most important naturally cultivated triploid variety ('Tahiti' lime) was probably originated through unreduced pollen from a diploid 'Mexican' lime (Curk et al., 2015). Luro et al. (2004) identified a few triploid hybrids produced by $2 \mathrm{n}$ pollen from three different mandarins, 'King', 'Hansen' and 'Ananas', 'Star Ruby' grapefruit and 'Tarroco Rosso' and 'Sanguinelli' sweet oranges. Later, Chen et al. (2008) recognized triploid hybrids resulting from 2 n-pollen of $P$. trifoliata in hybridizations with sweet orange. Recently, Honsho et al. (2016), identified giant pollen grains in 'Nishiuchi Konatsu' mandarin ( $C$. tamurana Hort. ex Tanaka) and based in single-pollen genotyping, revealed that FDR was the mechanism for the 2 n pollen gamete formation, although no plants were recovered.

\section{VII.2. Diploid gametes produced by tetraploid plants}

The main function of meiosis, in a generative reproduction concept, consists in creation of genetic variability during pairing, recombination, and segregation (Sybenga, 2012). In diploids, each pair of homologous chromosomes consists of one chromosome inherited from the female parent and the other one from the male parent. Chromosome association tends to align with strict bivalents formation (Otto, 2007). The increase of chromosome number by tetraploidization events results in duplicated sets of chromosomes. There is a basic classification of tetraploid plants based on the 
origin and type of chromosomes, autopolyploids and allopolyploids. Autopolyploids are produced from a variation of ploidy within a single species, and chromosomes display the same type and have the same origin. In contrast, allopolyploids contain two differentiated genomes, through the process of interspecific hybridization and subsequent chromosome doubling, being different the type and the origin of the chromosomes (Gallais, 2003).

In allotetraploids, there are two sets of homologous chromosomes and during meiosis, each chromosome pairs only with its homologous (Sybenga, 2012), and only bivalents are formed (Stebbins, 1947). It results in a disomic inheritance with $100 \%$ of the interspecific heterozygosity transmitted by each gamete (Stift et al., 2008). In autotetraploids, the presence of four homologous chromosomes instead of two, results in equal opportunities to pair at meiosis leading to multivalent formation and tetrasomic inheritance (Jackson and Jackson, 1996; Sybenga, 1996). For autotetraploid (doubled diploids), tetrasomic inheritance leads, hypothetically, to $66 \%$ of restitution of the heterozygosity of the diploid that originated the tetraploid (Sanford et al., 1983; Aleza et al., 2016a). Allo and autotetraploids (with disomic and tetrasomic inheritance, respectively) are the extremes of a range. In cases where parents are divergent but have retained enough homology to prevent exclusive preferential pairing, inheritance patterns intermediate 'segmental patter' between di- and tetrasomic can be expected (Stebbins, 1947; Sybenga, 1996; Stift, et al., 2008; Jeridi et al., 2012). Many different studies (Danzmann and Bogart, 1983; Hickok, 1978; Stift et al., 2008; Kamiri et al., 2011; Jeridi et al., 2012) have displayed that polyploid taxa presented inheritance patterns intermediate among disomic and tetrasomic.

Newly formed auto- and allopolyploids exhibit considerable meiotic complexity, including, double reduction (DR), asynapsis, inversions, reciprocal translocation and the production of unbalanced gametes (Sybenga, 1975).

In Rutaceae, Froelicher et al. (2000) were the first to study the meiotic behavior of the tetraploid Clausena excavata, belonging to the subfamily Aurantioideae, using molecular markers and displayed a strict disomic inheritance. Later, interspecific somatic hybrids has been studied (Fatta Del Bosco et al., 1999; Chen et al., 2004; Kamiri et al., 2011; Xie et al., 2015). For example, Del Bosco et al. (1999), Chen et al. (2004) and Kamiri et al. (2011) analyzed various allotetraploid somatic hybrids. The results obtained using cytogenetic techniques and molecular markers segregation was compatible with tetrasomic and intermediate between disomic and tetrasomic inheritance. Aleza et al. (2016a) produced an artificial doubled-diploid clementine by colchicine treatment. Molecular marker analysis revealed tetrasomic segregation although three LGs displayed intermediate segregation and one LG had a tendency for disomy. 
OBJECTIVES 

Ploidy manipulation is an attractive strategy in the modern citrus breeding programs aiming to obtain triploid and tetraploid plants. The creation of triploid hybrids is an important breeding strategy to develop new seedless citrus commercial varieties and tetraploid plants can be used as parents for triploids recovery through interploid sexual hybridizations. Rootstock breeding at tetraploid level is also considered as promising for increased adaptation to biotic and abiotic stresses.

In the last years, new methodologies have been developed enhancing the knowledge about genetics of citrus polyploid plants, especially in some mandarin elite cultivars. However it is necessary to continue enhancing the research and knowledge about genetic of citrus polyploid plants with economic relevancy like lemons and limes.

Sexual polyploidization by $2 \mathrm{n}$ female gametes is a relative frequent event in citrus and it has also been used worldwide for triploid breeding by $2 \mathrm{x} \times 2 \times$ sexual hybridizations. SDR mechanism has been identified as the main mechanism of $2 \mathrm{n}$ female gametes formation in mandarins although very few FDR $2 n$ gametes have been described. Nevertheless a small number of unreduced pollen gametes have been reported in citrus. In the framework of our triploid breeding program several $4 \mathrm{x} \times 2 \mathrm{x}$ hybridizations have been performed. Among these hybridizations, numerous tetraploid progenies have been recovered in two $4 \mathrm{x} \times 2 \mathrm{x}$ sexual hybridizations suggesting the occurrence of $2 \mathrm{n}$ pollen gametes. These progenies are of great value to study $2 \mathrm{n}$ pollen gametes, the mechanism underlying $2 \mathrm{n}$ gametes formation and their implications in citrus triploid breeding programs based on sexual polyploidization.

Other mechanisms leading to unreduced gamete formation have been described, such as pre-meiotic and post-meiotic genome doubling and both mechanisms have rarely been documented in plants. These mechanisms produce $2 \mathrm{n}$ gametes with different genetic structure. Pre-meiotic genome doubling originate $2 \mathrm{n}$ gametes equivalent to the meiosis of doubled diploid genotypes and PHR depends mainly on the chromosomal preferential pairing rate. In the case of post-meiotic genome doubling, haploid gametes undergo an extra round of genome duplication, leading to the formation of fully homozygous $2 \mathrm{n}$ gametes. Lemon is a direct hybrid between two genetically distant genotypes, sour orange and citron, and the specific origins of the homozygous alleles can easily be distinguished and recombination analysed. For this reason, $2 \mathrm{n}$ gametes produced by different genotypes of lemons can be used as a good model to test if other mechanism of $2 \mathrm{n}$ gametes can occur in citrus plants.

Somatic polyploidization is a relative frequent event in citrus and adventitious embryony from nucellar cells is the apomictic mechanism involved in citrus, so tetraploid plants can be produced by spontaneous duplication of chromosomes in nucellar cells. Some of these tetraploid are used for interploid breeding for the production of seedless varieties and "tetrazyg" hybridization for rootstock breeding. Understanding the meiotic behavior of these DD parents is fundamental to optimize these breeding strategies. Indeed, there are two extreme models for diploid gametes produced by tetraploid plants, disomic and tetrasomic, although some intermediate model have also been described. Lime is the only Citrus horticultural group with natural triploid germplasm. Spontaneous DD occurs and it was proposed that $C$. aurantifolia and $C$. latifolia triploid varieties resulted from the combination of a diploid gamete of a DD $C$. aurantifolia ('Mexican' lime type) with haploid gametes of $C$. medica and $C$. limon respectively. Limes market is currently very important and it has increased 
dramatically since eighties of the last century. However, lime production is based on a very narrow genetic basis including a few diploid and triploid cultivars and varietal diversification is needed. Knowledge about meiosis of tetraploid 'Mexican' lime is a key step for the development of new lime triploid varieties and it would greatly improve the efficiency of triploid lime breeding programs. It is moreover an interesting model for DD meiotic study considering the important genomic differentiation between its two ancestral progenitors: $C$. micrantha and $C$. medica.

The specific objectives of this $\mathrm{PhD}$ thesis are the following:

Objective 1: To define the mechanisms underlying unreduced pollen gamete formation in $4 \times x$ 2x sexual hybridizations.

In citrus there are no evidences about progenies obtained by $2 \mathrm{n}$ pollen gametes. In this $\mathrm{PhD}$ thesis we have recovered two different progenies of tetraploid hybrids by $4 \mathrm{x} \times 2 \mathrm{x}$ sexual hybridizations. We have analysed:

1. The origin of tetraploid progenies in tetraploid clementine by diploid tangor hybridization

2. The mechanisms underlying $2 \mathrm{n}$ pollen gamete formation in the diploid tangor

3. The implications of the identified mechanisms in citrus triploid breeding programs.

Objective 2: To define the frequencies and the mechanisms involved in the unreduced gametes production in two different genotypes of lemon

For lemon, the frequencies and the mechanisms of unreduced gametes production have been poorly studied. In this work, we have analyzed:

1. The frequencies of $2 \mathrm{n}$ gamete formation in two different genotypes of lemon, 'Eureka Frost' and 'Fino'.

2. The mechanisms leading to $2 \mathrm{n}$ gamete formation in these two genotypes.

3. The implications in lemon breeding programs based on sexual polyploidization by $2 n$ gametes.

Objective 3: To gain knowledge about meiosis of the doubled diploid 'Mexican' lime and the implications for lime triploid breeding programs.

Doubled-diploid 'Mexican' lime is a direct hybrid of two genetically distant species, $C$. medica and $C$. micrantha. Cytogenetic and molecular marker analysis of the DD 'Mexican' lime meiosis would greatly improve the efficiency of lime triploid breeding programs. In this context, we have analysed:

1. The inheritance model, disomic, tetrasomic or intermediate segregation, of the DD 'Mexican’ lime

2. The interspecific recombination pattern and the genetic structure of the resulting diploid gametes

3. The possibility that the 'Tahiti' and 'Tanepao' limes types derived from interploid hybridization based on their phylogenomic structure and the ones of the diploid gametes produced by the DD 'Mexican' lime. 
The manuscript is structured in three chapters, corresponding to published or submited scientific articles as follows:

CHAPTER 1. Tetraploid citrus progenies arising from FDRand SDR unreduced pollen in 4x x 2x hybridizations. Tree Genetics \& Genomes (2017) 13:10

CHAPTER 2. Unreduced Megagametophyte Production in Lemon Occurs via Three Meiotic Mechanisms, Predominantly Second-Division Restitution. Frontiers in Plant Science. Frontiers in Plant Science (2017) doi: 10.3389/fpls.2017.01211.

CHAPTER 3. Doubled diploid 'Mexican' lime display preferential disomic segregation compatible with interploid crosses origin of $C$. Latifolia and $C$. aurantifolia triploid limes. Annals of Botany, Submitted 


\section{CHAPTER I}

Tetraploid citrus progenies arising from FDR and SDR unreduced pollen in $4 \times x$ 2x hybridizations

Houssem Rouiss, José Cuenca, Luis Navarro, Patrick Ollitrault and Pablo Aleza

Tree Genetics \& Genomes (2017) 13:10 



\section{$\underline{\text { Abstract }}$}

Polyploid citrus arise by somatic and sexual polyploidization, and both have been used in triploid breeding programs. Sexual polyploidization is mainly achieved by First Division Restitution (FDR) or Second Division Restitution (SDR) meiotic restitution mechanisms. In citrus, mostly SDR producing $2 \mathrm{n}$ ovule has been described. However, we obtained 72 tetraploid hybrids from $4 \mathrm{x} \times 2 \mathrm{x}$ sexual hybridizations using two doubled-diploid mandarins as female parents ('Moncada' mandarin and 'Fina' clementine) and a diploid hybrid tangor as male parent (clementine $\mathrm{x}$ sweet orange 'CSO') suggesting $2 \mathrm{n}$ pollen formation. This material was used to confirm the existence of $2 \mathrm{n}$ pollen in Citrus and to analyze its origin. SSR and SNP molecular marker analyses revealed that 64 out of the 72 recovered tetraploid plants resulted from the fertilization of a reduced diploid female gamete by unreduced (diploid) pollen from 'CSO', whereas eight tetraploid plants arose from self-pollination of the tetraploid parent. The maximum-likelihood method based on parental heterozygosity restitution (PHR) of centromeric loci identified both FDR and SDR as the mechanisms leading to unreduced male gamete formation. From the 64 unreduced gametes produced by diploid 'CSO' tangor, $41(64.1 \%)$ were originated by FDR, whereas 12 $(18.8 \%)$ were significant for SDR. Non-conclusive results were obtained for 11gametes (17.2\%). The pattern of PHR variation of markers located along the linkage group 2 confirmed our results at population level. To our knowledge, this is the first report of tetraploid citrus progenies arising from unreduced pollen and the first description of the coexistence of two meiotic restitution mechanisms (SDR and FDR) producing unreduced pollen in citrus.

\section{Keywords}

Citrus, First-division restitution, Second-division restitution, SSR and SNP markers, Parental Heterozygosity Restitution 


\section{$\underline{\text { Introduction }}$}

Polyploidy is an important pathway for plant evolution and speciation (Gallais, 2003). Although the first polyploid was discovered over a century ago (Strasburger, 1910), the genetic and evolutionary implications of polyploidy are still being studied and discussed (De Storme and Geelen, 2013). On a practical level, there are many opportunities for exploitation of polyploidy as a valuable tool in plant breeding programs (Ortiz, 1997; Ollitrault et al., 2008; Cuenca et al., 2015). The two main mechanisms of polyploid formation are somatic doubling of chromosomes (somatic polyploidization) and meiotic nuclear restitution leading to unreduced gamete production (sexual polyploidization). In somatic polyploidization, chromosome restitution occurs during mitosis and all the chromosomes of a somatic cell are included in one daughter nucleus, giving rise to a cell with a doubled chromosome number (Carputo et al., 2003). Sexual polyploidization is originated through gametic non reduction, including three different mechanisms to produce unreduced gametes (De Storme and Geelen, 2013); pre and post-meiotic genome doubling, and meiotic restitution. Pre and post-meiotic doubling mechanisms are not as frequent an event in plants, whereas meiotic restitution have been identified in several, and is the main mechanism of $2 \mathrm{n}$ gamete formation (De Storme and Geelen, 2013). Occurrence of unreduced gametes have been observed in potato (Mok et al., 1975; Mendiburu and Peloquin, 1977 a, b), Achillea borealis (Ramsey, 2007), Ipomoea trifida (Iwanaga et al., 1991), Brassica spp. (Mason et al., 2011), Anthoxanthum alpinum (Bretagnolle, 2001), Musa spp. (Ortiz, 1997) Dactylis (Maciera et al., 1992), Rosa spp (Zlesak, 2009), maize (Rhoades et al., 1966), Populus (Liesebach et al., 2015) and Citrus (Frost and Soost, 1968; Esen and Soost, 1971; Geraci et al., 1975, Cuenca et al., 2015). If an equational mitosis of all chromosomes occurs in the first division instead of a reductional mitosis, a First-Division Restitution (FDR) will be produced. As a result, the non-sister chromatids are included in the same gamete (Gallais, 2003; Park et al., 2007; Cuenca et al., 2011). Furthermore, if the first mitosis occurs normally, but an omission of the second meiotic division occurs, a Second Division Restitution (SDR) will be produced with sister chromatids included in the same gamete (Gallais, 2003; Park et al., 2007; Cuenca et al., 2011). These two mechanisms gave rise to highly diverse genetic structures of gamete populations and therefore of breeding material. Understanding the origin and mechanisms underlying unreduced gamete formation open an exciting way to convert this knowledge into practical benefits for plant breeding programs (Brownfield and Köhler, 2011).

Citrus and related genera of Aurantioideae are generally diploid, usually x $=9$ (Krug, 1943), but some higher euploid genotypes are extant in the citrus germplasm. The most common euploid variations are triploids and tetraploids (Lee, 1988). Citrus polyploidy occurs through somatic or sexual polyploidization. Adventitious embryony from nucellar cells is the apomictic mechanism involved in citrus, so tetraploid plants can be produced by spontaneous duplication of chromosomes in nucellar cells (Aleza et al., 2011). Also, in citrus, artificial tetraploid plants have been obtained with antimitotic chemicals like colchicine and oryzalin (Aleza et al., 2009b). Tetraploid plants have been used as parents in $2 \times 1 \times 4$ and 4x x 2x interploid hybridizations (Cameron and Burnett, 1978; Starrantino and Recupero, 1981; Ollitrault et al., 2008; Grosser and Gmitter, 2011; Aleza et al., 2012a, b) with the objective to produce triploid seedless cultivars that are desirable for the fresh-fruit market. Sexual polyploidization by $2 \mathrm{n}$ female gametes is a relative frequent event in citrus (Esen and Soost, 1971; Luro et al., 2004; Aleza et al., 2015; Cuenca et al., 2015) and it has also been used for triploid breeding 
by 2x x 2x sexual hybridizations (Esen and Soost 1971; 1973; Ollitrault et al., 2008; Aleza et al., 2010b; Cuenca et al., 2015). SDR mechanism has been identified by Cuenca et al. (2015) as the main mechanism of $2 \mathrm{n}$ female gametes formation in mandarins. From $5432 \mathrm{n}$ gametes analyzed, only three triploid plants were obtained by FDR-2n female gametes and no $2 \mathrm{n}$ pollen gametes were identified. A few cases of unreduced pollen gametes have been reported in citrus. Luro et al. (2004) reported that $2 \mathrm{n}$ pollen gametes production is a rare event in citrus (less than $2 \%$ ). Recently, Honsho et al. (2012; 2016), identified giant pollen grains in 'Nishiuchi Konatsu' mandarin (Citrus tamurana Hort. ex Tanaka) and based in Single-pollen genotyping, revealed that FDR is the mechanism for the $2 \mathrm{n}$ pollen gamete formation, although no plants were recovered. Within the framework of the triploid breeding program carried out at IVIA since 1995, (Navarro et al., 2015) several 4x x 2x hybridizations have been performed (Aleza et al., 2012b). Among these, numerous tetraploid progenies have been recovered in two sexual hybridizations between tetraploid female parents and a diploid hybrid between clementine and sweet orange $[C$. sinensis L. Osb.; hereafter referred to as 'CSO' tangor] used as pollinator, suggesting the frequent occurrence of $2 \mathrm{n}$ pollen in 'CSO' tangor.

Different methodologies have been used for the identification of the mechanism underlying unreduced gamete formation. Cytological techniques were the first to be used (Karlov et al., 1999), but the small size of the chromosomes, like in citrus, is the major handicap for the implementation of these techniques (Barba-Gonzalez et al., 2005; Jaskani et al., 2007). Molecular marker analysis is used for the estimation of parental heterozygosity restitution (PHR) through unreduced gametes in polyploid progenies (Barone et al., 1995; Vorsa and Rowland, 1997; Luro et al., 2004; Bastiaanssen et al., 1998; Cuenca et al., 2011, 2015). Most of the previously developed methodologies are based on the genetic analysis of a high number of random molecular markers. Markers with PHR lower than 50\% indicate that the progeny was originated by SDR (Park et al., 2007) whereas with PHR over 50\%, for all analyzed markers, no definitive conclusion between SDR or FDR can be obtained without previous knowledge of their genetic distance to the centromere. Tavoletti et al. (1996) developed a multilocus maximum-likelihood method of Half Tetrad Analysis (HTA) to estimate the relative frequencies of FDR and SDR that was also useful for mapping centromere position. In citrus, taking advantage of the centromeres location (Aleza et al., 2015) in the reference genetic map (Ollitrault et al., 2012a), Cuenca et al. (2015) developed a maximum-likelihood methodology to identify the unreduced gamete formation mechanism both at the population and individual levels using independent centromeric markers.

The objective of this work was to confirm the hypothesis of $2 \mathrm{n}$ pollen formation in ' $\mathrm{CSO}^{\prime}$ ' tangor and to analyze the mechanisms underlying $2 \mathrm{n}$ pollen formation. We applied the maximum likelihood methodology based on centromeric molecular markers to identify the unreduced gamete formation mechanisms at individual level and validated our results by the analysis of PHR along one linkage group. Finally we discuss the applications and implications of such mechanisms in citrus triploid breeding programs. 


\section{Materials and Methods}

\section{Plant material}

Tetraploids of 'Moncada' mandarin( $C$. clementina x (C. unshiu x $C$. nobilis $)$ ) and 'Fina' clementine (C. clementina) were obtained at IVIA by shoot-tip grafting in vitro combined with colchicine treatment as described by Aleza et al. (2009). They are therefore doubled diploid genotypes. They were pollinated with 'CSO' diploid tangor. Hereafter hybridization between 'Moncada' mandarin and 'Fina' clementine by diploid 'CSO' tangor we referred to as MCSO and FCSO respectively. Ploidy level analysis of the obtained plants were performed by flow cytometry as described in Aleza et al. (2012b). Respectively, ten and 62 tetraploid plants were recovered from normal seeds in the MCSO and FCSO hybridization. These 72 tetraploid plants and their parents were used in this work.

\section{SSR and SNP genotyping}

The female and male parents together with the progenies recovered from both $4 \mathrm{x} x 2 \mathrm{x}$ sexual hybridizations were genotyped using SSR and SNP markers. The markers are distributed across the nine LGs of the clementine genetic map (Ollitrault et al., 2012a). Markers that indicated heterozygosity for the 'CSO' tangor and polymorphism with 'Moncada' mandarin and 'Fina' clementine were selected and used for the progenies genotyping (Table 1.1). As ' $\mathrm{CSO}^{\prime}$ ' is a hybrid between clementine and sweet orange and, as clementine is a hybrid itself between 'Common' mandarin and sweet orange (Ollitrault et al., 2012a; Garcia-Lor et al., 2012; Wu et al., 2014), it was difficult to find heterozygous markers for 'CSO' tangor with polymorphism with clementine. Ninetyeight SSR and six SNP markers were tested and 100 new centromeric SSR markers were designed. From the 100 new centromeric SSR markers designed, only 5AT21 and 9TAA22 SSR markers, located in LGs 5 and 9, respectively, displayed the appropriate configuration to be used in this study (Table 1.1). We found a total of twelve SSR and four SNP markers with adequate allelic configuration between parents from the 198 SSR and six SNP markers as tested.

DNA from leaves of the recovered plants and their parents was isolated using the Plant DNAeasy kit from Qiagen Inc. (Valencia, CA, USA), following the manufacturer's protocol. PCR amplifications, using SSR markers, were performed using a Thermocycler rep gradient $S$ (Eppendorf®) in $10 \mu \mathrm{L}$ final volume containing $0.8 \mathrm{U}$ of Taq DNA polymerase (Fermentas $\left.{ }^{\circledR}\right), 2 \mathrm{ng} / \mathrm{mL}$ of citrus DNA, $0.2 \mathrm{mM}$ of wellRED (Sigma ${ }^{\circledR}$ ) dye-labelled forward primer, $0.2 \mathrm{mM}$ of non dye-labelled reverse primer, $0.2 \mathrm{mM}$ of each dNTP, 10X PCR buffer and $1.5 \mathrm{mM} \mathrm{MgCl}$. The PCR protocol was as follows: denaturation at $94^{\circ} \mathrm{C}$ for $5 \mathrm{~min}$ followed by 40 repeats of $30 \mathrm{~s}$ at $94^{\circ} \mathrm{C}, 1 \mathrm{~min}$ at $50^{\circ} \mathrm{C}$ or $55^{\circ} \mathrm{C}, 45 \mathrm{~s}$ at $72^{\circ} \mathrm{C}$; and a final elongation step of 4 min at $72^{\circ} \mathrm{C}$. Capillary electrophoresis was carried out using a CEQ ${ }^{\mathrm{TM}} 8000$ Genetic Analysis System (Beckman Coulter Inc.). PCR products were initially denatured at $90^{\circ} \mathrm{C}$ for 2 min, injected at $2 \mathrm{kV}$ for $30 \mathrm{~s}$ and subsequently separated at $6 \mathrm{kV}$ for $35 \mathrm{~min}$. Alleles were sized, based on a DNA size standard (400 bp). The GenomeLab ${ }^{\mathrm{TM}}$ GeXP v.10.0 genetic analysis software was used for data collection. Allele dosage was calculated using the MAC-PR (microsatellite DNA allele counting-peak ratio) method (Esselink et al., 2004), validated in citrus by Cuenca et al. (2011). 
Table 1.1. Information on used molecular markers with their Gene Bank or Phytozome accesion, position in the Clementine reference genetic map (Ollitrault et al., 2012b), parental genotypes and bibliographic references

\begin{tabular}{|c|c|c|c|c|c|c|c|c|}
\hline \multirow{2}{*}{ Locus } & \multirow{2}{*}{$\begin{array}{c}\text { Gene Bank/ } \\
\text { Phytozome } \\
\text { Accesion }\end{array}$} & \multirow{2}{*}{$\begin{array}{l}\text { Linkage } \\
\text { Group }\end{array}$} & \multirow{2}{*}{$\begin{array}{c}\text { Genetic } \\
\text { map } \\
\text { locus } \\
\text { position } \\
\text { (cM) } \\
\end{array}$} & \multirow{2}{*}{$\begin{array}{l}\text { Distance to } \\
\text { centromere } \\
\text { (cM) }\end{array}$} & \multicolumn{3}{|c|}{ Noted alleles ${ }^{1}$} & \multirow{2}{*}{$\begin{array}{l}\text { Bibliographic } \\
\text { reference }\end{array}$} \\
\hline & & & & & Clementine & Moncada & CSO & \\
\hline CIBE5720 & ET082224 & 1 & 58,45 & 2,2 & $325-337$ & $329-337$ & $325-340$ & $\begin{array}{r}\text { Ollitrault } e t a l . \\
(2010)\end{array}$ \\
\hline MEST539 & DY294904 & 1 & 61,82 & 1,2 & $104-108$ & $98-104$ & 104-108 & In preparation \\
\hline mCrCIR03C08 & FR677576 & 2 & 82,19 & 25,3 & $208-226$ & $221-225$ & $208-212$ & Cuenca et al. (2011) \\
\hline CIBE6006 & ET084205 & 2 & 124,01 & 67,1 & $176-200$ & $176-200$ & $197-200$ & $\begin{array}{r}\text { Ollitrault et al. } \\
\text { (2010) }\end{array}$ \\
\hline $2 \mathrm{p} 21022555$ & $\begin{array}{c}\text { Ciclev10018135 } \\
\text { m.g }\end{array}$ & 2 & 57,00 & 0,1 & A-A & $\mathrm{T}-\mathrm{T}$ & A-T & Curk et al. (2015) \\
\hline CX6F23 & CF417259 & 2 & 49,53 & 7,3 & $149-161$ & $149-161$ & $155-161$ & Chen et al. (2006) \\
\hline mCrCIR04H06 & FR677579 & 2 & 23,65 & 33,2 & 190-196 & 190-196 & $184-196$ & Cuenca et al. (2011) \\
\hline 3p35931624 & $\begin{array}{c}\text { Ciclev10023979 } \\
\text { m.g }\end{array}$ & 3 & 95,10 & 4,5 & G-G & G-G & G-A & This manuscript ${ }^{2}$ \\
\hline $\mathrm{TC} 01$ & CK934237 & 3 & 96,00 & 5,4 & $333-348$ & $329-333$ & $333-351$ & In preparation \\
\hline CF-ACA01 & CN181701.1 & 4 & 24,41 & 8,3 & $335-338$ & $335-335$ & $335-338$ & In preparation \\
\hline $5 \mathrm{AT} 21$ & none & 5 & 17,53 & 5,6 & $254-254$ & $254-262$ & $240-254$ & This manuscript ${ }^{3}$ \\
\hline CiC4356-06 & ET111465 & 6 & 6,21 & 0,2 & C-T & $\mathrm{C}-\mathrm{C}$ & C-T & $\begin{array}{r}\text { Ollitrault } e t a l \text {. } \\
\text { (2012b) }\end{array}$ \\
\hline mCrCIR01C06 & FR692356 & 6 & 88,92 & 82,5 & $133-165$ & $131-165$ & 159-165 & Cuenca et al. (2011) \\
\hline Ci07C07 & AJ567409 & 7 & 98,02 & 1,6 & $228-240$ & $228-234$ & $228-240$ & $\begin{array}{r}\text { Froelicher } \text { et al. } \\
(2008)\end{array}$ \\
\hline LCY2-M-376 & FJ516403 & 8 & 58,10 & 3,9 & A-G & G-G & A-G & $\begin{array}{r}\text { Ollitrault et al. } \\
\text { (2012b) }\end{array}$ \\
\hline 9TAA22 & none & 9 & 62,57 & 10,4 & $150-203$ & $151-157$ & $164-203$ & This manuscript ${ }^{4}$ \\
\hline
\end{tabular}

1. Noted alleles. The numbers indicate the size of alleles in nucleotides for SSR markers and letters correspond to SNP markers 2. SNP flanking sequence:

GAAGAGTTTCTTCTTAACAGTGGCCAAATTTTTCGAGTGGCCTGTGACAA[G/A]TACGGAAACTATGTGATTCAAAC AGCATTGATCGAGACAATGCGACCGAA

3. Primer's sequence of 5AT21 SSR marker: Forward: TGGTAGAAAATGTTGAATTGACG, Reverse:

AATCAAATTGGCTTTTTGGAA.

4. Primer's sequence of 9TAA22 SSR marker: Forward: ATGACGACCCACCAAAGAAA, Reverse:

Parents and progenies were also genotyped with SNP markers using KASPar technology by LGC Genomics (http://www.lgcgenomics.com). The KASParTM Genotyping System is a competitive, allele-specific dual Förster Resonance Energy Transfer (FRET)-based assay for SNP genotyping. Primers were designed by LGC Genomics Company based on the SNP locus flanking sequence (approximately $50 \mathrm{nt}$ on each side of the SNP). SNP genotyping was performed using the KASPar technique. Detailed explanation on specific conditions and reactives can be found in Cuppen, (2007). Identification of allele doses in heterozygous tetraploid hybrids has been carried out from the relative allele signals as described by Cuenca et al. (2013a). 


\section{Data analysis}

Identification of the origin of tetraploid plants and inference of the unreduced gamete genotype

Determination of the origin of tetraploid plants was performed by molecular marker analysis. The two hypotheses tested were (i) self-fertilization of the tetraploid female parent and (ii) fertilization by a diploid pollen of the diploid 'CSO' tangor. Markers with total differentiation between the parents (A1A1A1A1 x A2A2; A1A1A1A1 x $\mathrm{A} 2 \mathrm{~A} 3, \mathrm{~A} 1 \mathrm{~A} 1 \mathrm{~A} 2 \mathrm{~A} 2 \times \mathrm{A} 3 \mathrm{~A} 4)$ were more useful for this purpose as only one marker was sufficient to conclude. For MCSO hybridization, we have used the mCrCIR03C08 SSR marker. However, for FCSO hybridization, as 'CSO' is a hybrid itself of clementine, the two parents share at least one allele and five kinds of allelic configurations encountered from the two parents (A1A1A1A1 x A1A1; A1A1A2A2 $x$ A1A2; A1A1A2A2 x A1A1; A1A1A1A1 x A1A2: A1A1A2A2 x A1A3). Only the last two configurations provide the opportunity to demonstrate fertilization by diploid ' $\mathrm{CSO}^{\prime}$ ' tangor and were used for the FCSO hybridization. The probability that the specific allele of the 'CSO' parent does not pass to the tetraploid progeny in case it arise from an unreduced pollen of ' $\mathrm{CSO}^{\prime}$ ' is 0.5 . With independent marker, the probability that such an event being unidentified, decreases to $0.5^{\mathrm{n}}$.

When it was demonstrated that a tetraploid plant resulted from the fertilization by unreduced pollen of CSO, we performed the inference of the unreduced gamete genotype for the markers in heterozygosity for CSO. For a locus bearing completely different parental allelic configurations (case of MCSO hybridization), A1A1A2A2 x $\mathrm{A} 3 \mathrm{~A} 4$ and A1A1A1A1 x A3A4, the genotype of the unreduced gamete was deduced directly from the observation of the A 3 and A4 alleles in the tetraploid hybrids. When the male and female genitor shared one allele (A1A1A1A 1 x A1A2 and A1A1A2A2 x A1A3), for the tetraploid hybrids that have inherited the common allele from the female genitor, the inference of the unreduced male gamete structure was carried out from the estimated allele dosage in the tetraploid hybrid.

\section{Mechanism of unreduced gamete formation}

Once $2 \mathrm{n}$ pollen of CSO were identified, the maximum-likelihood method developed by Cuenca et al. (2015) was used to identify the mechanism of unreduced gamete formation at population and individual levels using PHR values of centromeric markers.

Taking advantage of the reference genetic map of clementine (Ollitrault et al., 2012a) and the centromeres location (Aleza et al., 2015), three SSR markers (CIBE5720, 5AT21 and 9TAA22) and two SNP markers (2p21022555 and 3p35931624), located in five different LGs $(1,2,3$, 5and 9 respectively), were used to identify the mechanism underlying $2 \mathrm{n}$ gametes formation in tetraploid plants recovered from FCSO hybridization while seven SSR markers (MEST539, CX6F23, JC-TC01, CFACA01, 5AT21, Ci07C07 and 9TAA22) and two SNP markers (CiC4356-06 and LCY2-M-376) located in the nine LGs, were used for MCSO tetraploid plants (Table 1.1). All markers used are located less than $10 \mathrm{cM}$ from the centromere. At individual level, the probabilities of a heterozygous or a homozygous diploid gamete occurring at a locus, under the two models (SDR/FDR), were calculated. Next, LOD values were estimated from the probabilities of a marker being inherited as heterozygous or homozygous under the SDR or FDR mechanisms (LOD=log (pSDR/pFDR). LOD 
scores greater than 2 or below -2 were considered as thresholds indicating that SDR and FDR, respectively, were the mechanism involved in the single unreduced gamete formation. For LOD scores between 2 and -2 , no significant conclusions were considered (Cuenca et al., 2015).

\section{Pattern of PHR along the LG 2 for the unreduced pollen population}

Genetic analysis with markers distributed along a LG can also be used to identify the mechanism underlying 2n gamete formation (Park et al., 2007), as we have previously corroborated in 'Fortune' mandarin (Cuenca et al., 2011) and clementine (Aleza et al., 2015). Thus, as a complementary study of the centromeric markers analysis, we analyzed the PHR pattern along the LG2 in the $2 \mathrm{n}$ pollen gamete progenies with four SSR markers (mCrCIR04H06, CX6F23, mCrCIR03C08 and CIBE6006) and one SNP marker (2p21022555). mCrCIR04H06 and CIBE6006 are telomeric markers, 2 p21022555 is located very close to the centromere and the last two markers are located between telomere and centromere at each side of the LG.

\section{Population diversity organization}

Population diversity organization was examined by Unweighted Pair Group Method with Arithmetic Mean (UPGMA) analysis. DARwin5 software (Perrier and Jacquemoud-Collet, 2006) was used to compute the simple matching dissimilarity index (di-j) between pairs of loci (units):

$$
d_{i-j}=1-\frac{1}{L} \sum_{l=1}^{L} \frac{m_{l}}{\pi}
$$

where $d_{i-j}$ is the dissimilarity between units $i$ and $j, L$ is the number of loci, and $m_{l}$ is the number of matching alleles for locus $l$. Then the UPGMA tree was computed with MEGA 6 software from the dissimilarity matrix. 


\section{$\underline{\text { Results and Discussion }}$}

\section{Genetic origin of tetraploid hybrids recovered from $4 \times x \times 2 \times$ sexual hybridizations}

Tetraploid plants from MCSO hybridization were first analyzed with CIBE5720 and mCrCIR03C08 SSR markers. Results revealed that they arise from the fertilization of diploid female gametes by unreduced pollen gametes of the 'CSO' diploid tangor (Figure 1.1).

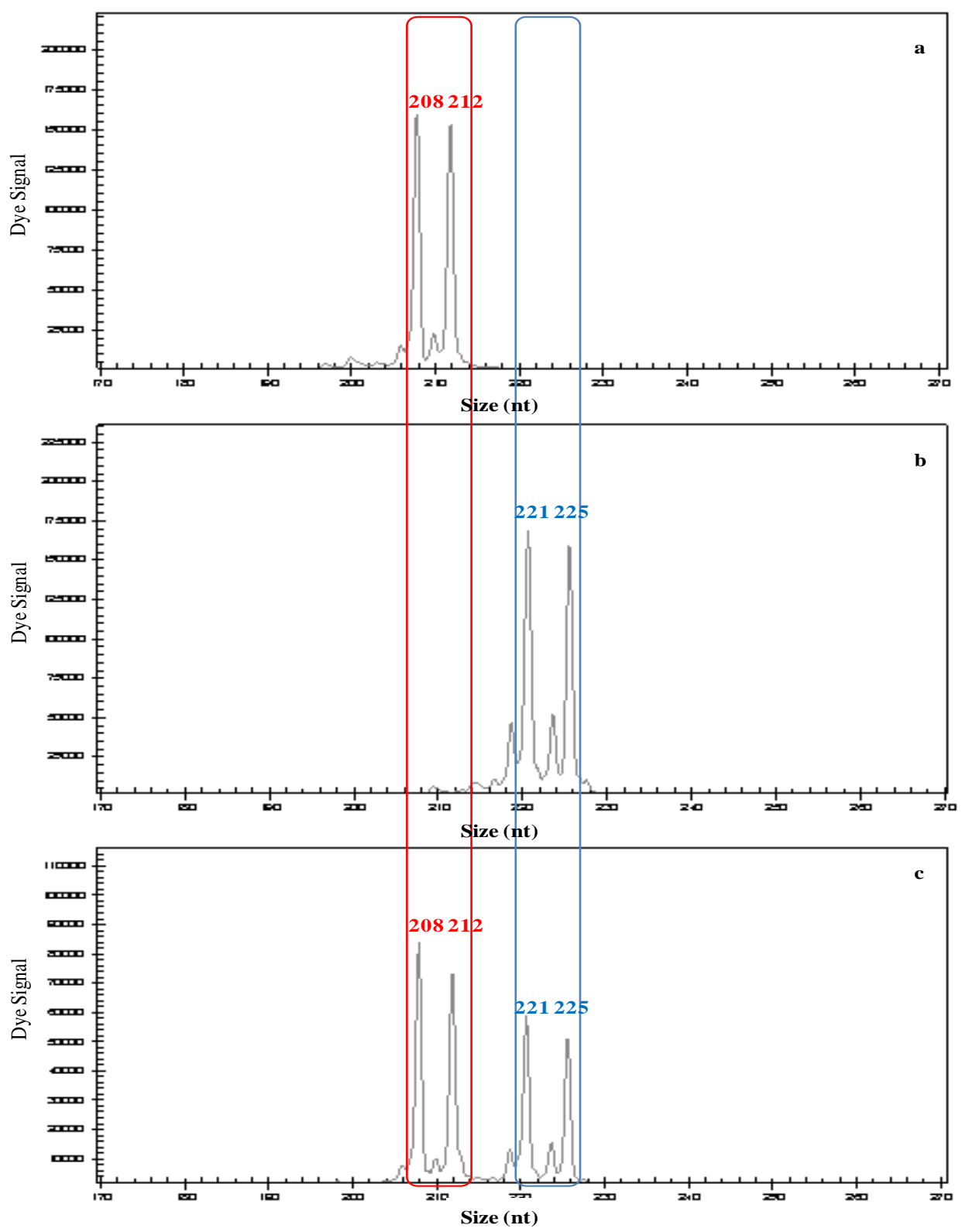

Figure 1.1. Electropherograms obtained using mCrCIR03C08 SSR marker in a: diploid tangor 'CSO', b: tetraploid 'Moncada' mandarin, c: tetraploid hybrid displaying the alleles of both parents recovered from MCSO hybridization. The numbers indicate the size of alleles in nucleotides (nt) for each genotype.

In the FCSO hybridization, from 62 tetraploid plants, eight displayed only specific alleles of the DD parent and never exhibited the specific alleles of the 'CSO' parent 
(supplementary file 1). Under the hypothesis of cross pollination with CSO $2 \mathrm{n}$ gametes arising from FDR or SDR, the probabilities to observe, at individual level, such configurations without the CSO specific alleles are respectively $\mathrm{P}=8.03 \mathrm{E}-12$ and $\mathrm{P}=5.18 \mathrm{E}-4$. Therefore the hypothesis of cross-pollination with CSO $2 \mathrm{n}$ gametes can be rejected for these plants. Moreover none of these plants are identical to the DD Clementine (Additional table 1.1$)$ as they display different allele doses $(0 / 4 ; 3 / 1 ; 1 / 3$ or $4 / 0$ ) for the loci heterozygous in Clementine ( $2 / 2$ dose in the DD). Therefore they are not tetraploid nucellar plants and the presence of allelic recombination proved that these plants were originated by self-pollination of the DD female parent. The remaining 54 tetraploid hybrids resulted from the fertilization of reduced diploid female gamete by unreduced pollen gametes of the 'CSO' diploid tangor (Figure 1.2). This is the first report of citrus tetraploid progenies recovered from unreduced pollen gametes in $4 \mathrm{x} \times 2 \mathrm{x}$ sexual hybridizations. This phenomenon has been observed and studied in other species like Lilium (Lim et al., 2004), potato (Mendiburu and Peloquin, 1977b; Hutten et al., 1994; Carputo et al., 2003; Park et al., 2007) Boecheraspp. (Mau et al., 2013) and Arabidopsis (d'Erfurth et al., 2008).

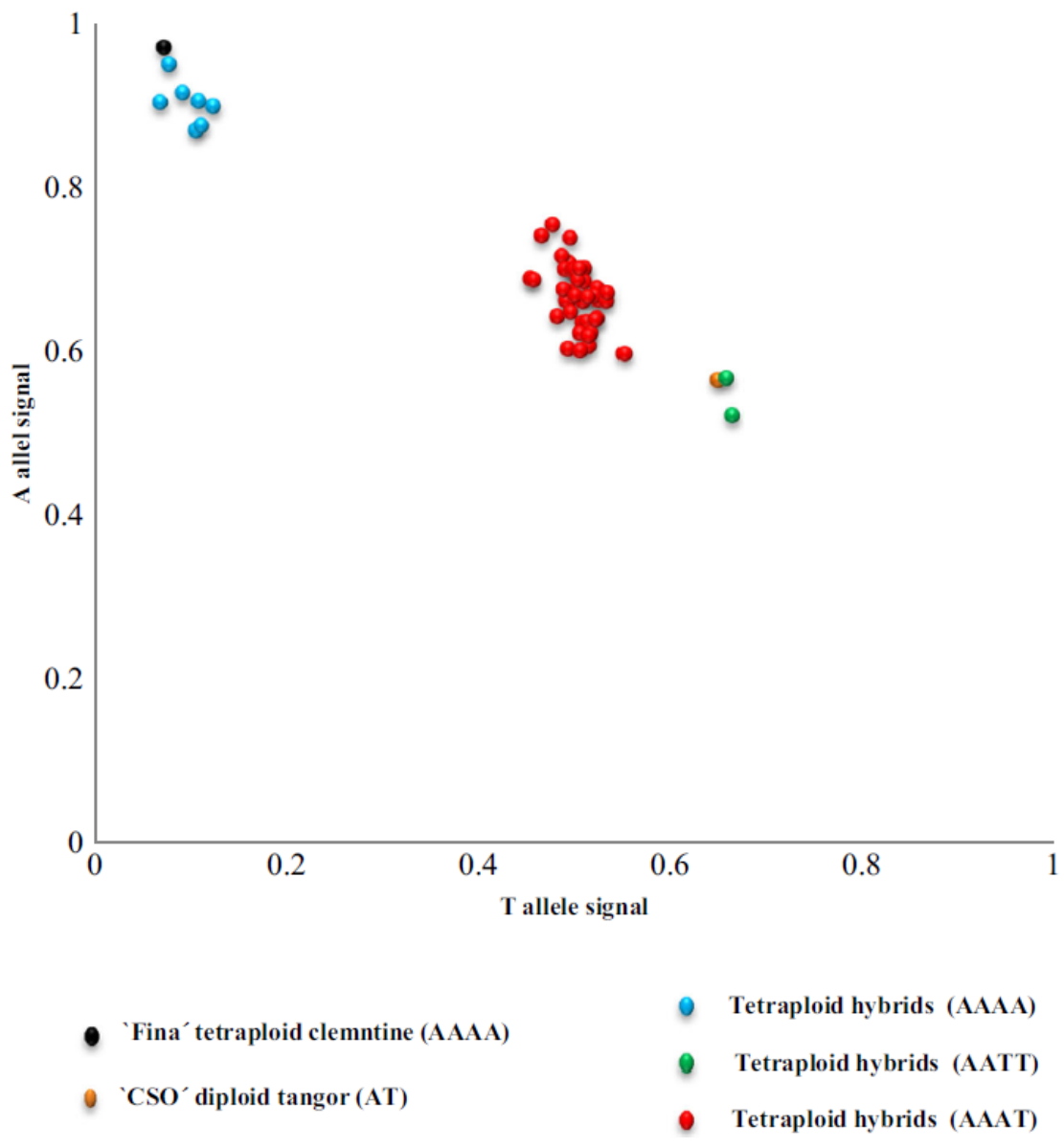

Figure 1.2. Plot of normalized $A, T$ allele signals from cluster analysis over 54 tetraploid hybrids from the hybridization between tetraploid 'Fina' clementine and diploid tangor 'CSO' with the 2p21022555 SNP marker. Tetraploid hybrids (AAAA) and (AATT) originated from homozygous unreduced pollen grain (AA and TT) and tetraploid hybrids (AAAT) originated from heterozygous unreduced pollen grain (AT). 
Tetraploid plants in tentative $4 \mathrm{x} \times 2 \mathrm{x}$ sexual hybridizations have been previously reported in citrus and were originated by selfing of the tetraploid female parent (Aleza et al., 2012b). We have observed the same result in eight over the 72 tetraploid recovered plants. Xie et al. (2014) also recovered tetraploid plants from the reciprocal hybridization, $2 \mathrm{x} \times 4 \mathrm{x}$, and tetraploid plants were originated as a consequence of $2 \mathrm{n}$ female gametes. Here, we have obtained a high number of tetraploid hybrids from $2 \mathrm{n}$ pollen gametes (64 over 72 tetraploid recovered plants from only 50 and 32 collected fruits of MCSO and FCSO respectively). Ramsey and Schemske; (1998) suggested that the frequency of polyploid plants is related to the effect of environmental conditions and their genotypes. Great differences in frequencies of $2 \mathrm{n}$ gametes between genotypes have been observed in citrus (Aleza et al., 2010b), peach (Dermen, 1938) and potato (Mok and Peloquin, 1975). Watanable and Peloquin, (1993) indicated that $2 \mathrm{n}$-pollen gamete frequencies can range between 1.9 to $36 \%$ in diploid, tetraploid and hexaploid Solanum species. As well as the high variability reported in Dactylis, Trifolium, Manihot and Medicago (Bregtanolle and Thompson, 1995).

Most studies on 2n citrus gametes were performed from 2x x 2x hybridizations where triploid embryos are included in small seeds with a 3:5 embryo-endosperm ploidy level ratio. Esen and Soost, $(1971 ; 1973)$ indicated that the ratio between the ploidy level of embryos and endosperm was responsible for seed size reduction, since pentaploid endosperms grow slower and stop seed development prematurely. In this context there are very few reports about polyploid plants produced by unreduced pollen gametes. Luro et al. (2004) described a few triploid plants recovered from unreduced male gametes of 'Ananas' ( $C$. reticulata Blanco), 'Hansen' ( $C$. reticulata Blanco) and 'King' mandarins ( $C$. nobilis Lour.), 'Star Ruby' grapefruit ( $C$. paradisi (Macf.), 'Tarocco Rosso' and 'Sanguinelli' sweet oranges. The very low rates of triploids arising from unreduced pollen in $2 \mathrm{x} \times 2 \mathrm{x}$ hybridization was confirmed later by Cuenca et al. (2015). In a diploid plant, when pollinated by diploid pollen, the embryo/endosperm ratio (3/4) is less favorable than the $2 / 3$ occurring in normal embryos in diploid hybridization, while the pollination of a tetraploid plant by a diploid pollen provides a correct embryo/endosperm ploidy ratio $(4 / 6=2 / 3)$ leading to normal seed development. Tetraploid $\mathrm{x}$ diploid hybridization is therefore the better situation to reveal the existence of unreduced pollen by the production of tetraploid embryos in normal seeds.

\section{Mechanism of unreduced pollen formation}

For heterozygous markers at parental level, meiotic cells without crossing over between the centromere and the considered marker will produce heterozygous FDR$2 n$ gametes and homozygous SDR-2n gametes. While when one crossing over occurs between the centromere and the considered locus, 50\% of FDR-2n gametes will be heterozygous (and 50\% homozygous), but all SDR gametes will be heterozygous at this locus (Park et al., 2007). Therefore, the probabilities of a $2 \mathrm{n}$ gamete being heterozygous or homozygous for a marker, as a consequence of FDR or SDR mechanisms are direct functions of the marker-centromere distance (Park et al., 2007). Moreover for one meiotic cell, the occurrence of crossing over is totally independent between the different chromosomes; therefore the restitution of heterozygosity in $2 \mathrm{n}$ gametes for markers in different chromosome is also independent.

Maximum-likelihood method based on PHR of the centromeric markers developed by Cuenca et al. (2015) was used to identify the mechanism of unreduced pollen gamete 
formation in tetraploid plants recovered from $4 \times$ x $2 x$ sexual hybridizations. For each $4 x$ hybrid, the LOD score for SDR/FDR probabilities was done from individual's multilocus allelic configuration (Additional tables 1.2 and 1.3).

LODs values for the ten $4 \mathrm{x}$ hybrids of MCSO hybridization (Table 1.2), indicated that six plants displayed LOD values between -8.28 and -4.39 , being conclusive for FDR, two plants showed LOD values higher than 2, significant for SDR, and two plants had LOD values of -0.96 and 0.30 , not allowing to conclude between the FDR and SDR mechanisms.

Table 1.2. Analysis at individual and population level of the origin of 'CSO' tangor $2 \mathrm{n}$ gametes recovered from DD 'Moncada' mandarin by 'CSO' diploid tangor sexual hybridization using markers close to the centromeres of all LGs and the LOD score test probability ratio for SDR/FDR

\begin{tabular}{|c|c|c|c|c|c|c|c|c|c|c|}
\hline $\begin{array}{l}\text { Closest } \\
\text { marker to } \\
\text { the } \\
\text { centromere }\end{array}$ & $\begin{array}{c}\text { MEST } \\
539\end{array}$ & $\begin{array}{c}\text { CX6F2 } \\
3\end{array}$ & TC01 & $\begin{array}{c}\text { CF- } \\
\text { ACA01 }\end{array}$ & 5АT21 & $\begin{array}{c}\mathrm{CiC} 4356 \\
-06\end{array}$ & $\begin{array}{c}\mathrm{Ci07C0} \\
7\end{array}$ & $\begin{array}{l}\text { LCY2-M- } \\
\quad 376\end{array}$ & $\begin{array}{c}\text { 9AAT2 } \\
2\end{array}$ & \\
\hline LG & 1 & 2 & 3 & 4 & 5 & 6 & 7 & 8 & 9 & \\
\hline $\begin{array}{l}\text { Centromere } \\
\text { Position } \\
(\mathrm{cM})\end{array}$ & 60.7 & 56.9 & 90.6 & 16.1 & 23.1 & 6.4 & 96.4 & 54.2 & 52.2 & \\
\hline $\begin{array}{l}\text { Marker } \\
\text { Position } \\
(\mathrm{cM})\end{array}$ & 61.8 & 49.5 & 96.0 & 24.4 & 17.5 & 6.2 & 98.0 & 58.1 & 62.6 & \\
\hline $\begin{array}{l}\text { Marker } \\
\text { distance to } \\
\text { centromere } \\
(\mathrm{cM})\end{array}$ & 1.2 & 7.3 & 5.4 & 8.3 & 5.6 & 0.2 & 1.6 & 3.9 & 10.4 & OD \\
\hline $\begin{array}{l}\text { Individuals } \\
\text { analyzed }\end{array}$ & \multicolumn{9}{|c|}{ Individual multilocus allelic configuration } & $\begin{array}{l}\text { (SDR/ } \\
\text { FDR) }\end{array}$ \\
\hline MCSO 03 & $\mathrm{HE}$ & $\mathrm{HE}$ & $\mathrm{HE}$ & $\mathrm{HE}$ & $\mathrm{HE}$ & $\mathrm{HE}$ & $\mathrm{HE}$ & $\mathrm{HE}$ & $\mathrm{HE}$ & -8.28 \\
\hline MCSO 09 & $\mathrm{HE}$ & $\mathrm{HE}$ & $\mathrm{HE}$ & $\mathrm{HE}$ & $\mathrm{HE}$ & $\mathrm{HE}$ & $\mathrm{HE}$ & $\mathrm{HE}$ & $\mathrm{HE}$ & -8.28 \\
\hline MCSO 05 & $\mathrm{HE}$ & $\mathrm{HE}$ & $\mathrm{HE}$ & $\mathrm{HE}$ & $\mathrm{HE}$ & $\mathrm{HE}$ & $\mathrm{HE}$ & $\mathrm{HE}$ & $\mathrm{HO}$ & -6.68 \\
\hline MCSO 08 & $\mathrm{HE}$ & $\mathrm{HE}$ & $\mathrm{HE}$ & $\mathrm{HE}$ & $\mathrm{HE}$ & $\mathrm{HE}$ & $\mathrm{HE}$ & $\mathrm{HO}$ & $\mathrm{HE}$ & -6.40 \\
\hline MCSO 10 & $\mathrm{HO}$ & $\mathrm{HO}$ & $\mathrm{HE}$ & $\mathrm{HE}$ & $\mathrm{HE}$ & $\mathrm{HE}$ & $\mathrm{HE}$ & $\mathrm{HE}$ & $\mathrm{HE}$ & -5.16 \\
\hline MCSO 02 & $\mathrm{HE}$ & $\mathrm{HE}$ & $\mathrm{HE}$ & $\mathrm{HE}$ & $\mathrm{HO}$ & $\mathrm{HE}$ & $\mathrm{HO}$ & $\mathrm{HE}$ & $\mathrm{HE}$ & -4.39 \\
\hline MCSO 06 & $\mathrm{HE}$ & $\mathrm{HE}$ & $\mathrm{HE}$ & $\mathrm{HE}$ & $\mathrm{HE}$ & $\mathrm{HO}$ & $\mathrm{HE}$ & $\mathrm{HO}$ & $\mathrm{HO}$ & -0.96 \\
\hline MCSO 07 & $\mathrm{HE}$ & $\mathrm{HO}$ & $\mathrm{HE}$ & $\mathrm{HE}$ & $\mathrm{HO}$ & $\mathrm{HO}$ & $\mathrm{HE}$ & $\mathrm{HO}$ & $\mathrm{HE}$ & 0.30 \\
\hline MCSO 04 & $\mathrm{HE}$ & $\mathrm{HE}$ & $\mathrm{HO}$ & $\mathrm{HO}$ & $\mathrm{HO}$ & $\mathrm{HE}$ & $\mathrm{HO}$ & $\mathrm{HO}$ & $\mathrm{HE}$ & 2.06 \\
\hline MCSO 01 & $\mathrm{HO}$ & $\mathrm{HO}$ & $\mathrm{HO}$ & $\mathrm{HE}$ & $\mathrm{HO}$ & $\mathrm{HE}$ & $\mathrm{HO}$ & $\mathrm{HE}$ & $\mathrm{HO}$ & 2.62 \\
\hline \multicolumn{10}{|c|}{ Population LOD } & -35.17 \\
\hline
\end{tabular}

LODs > 2 are significant for SDR, LODs> -2 are significant for FDR and, LODs between 2 and -2 do not allow to conclude between SDR and FDR hypotheses. cM. Centimorgans. HO Homozygous and HE heterozygous

Regarding the 54 tetraploid plants recovered from FCSO hybridization (Table 1.3), LOD valuesrangedfrom-6.36 to 7.75. Thirty-five plants displayed a LOD value between -6.36 to -2.28 and were considered significant for the FDR $2 \mathrm{n}$ gamete formation mechanism. Ten plants showed LOD values between 2.04 and 7.75 , being significant for the SDR mechanism. 
Table 1.3. Analysis at individual level of the origin of ' $\mathrm{CSO}^{\prime}$ ' tangor $2 \mathrm{n}$ gametes recovered from DD 'Fina' clementine by 'CSO' diploid tangor sexual hybridization using markers close to the centromeres of five different LGs and the LOD score test probability ratio for SDR/FDR.

\begin{tabular}{|c|c|c|c|c|c|c|}
\hline Closest marker to the centromere & CIBE5720 & $2 p 21022555$ & $3 p 35931624$ & 5АT21 & 9ТАA22 & \multirow{5}{*}{$\begin{array}{c}\text { LOD } \\
\text { (SDR/FDR) }\end{array}$} \\
\hline LG & 1 & 2 & 3 & 5 & 9 & \\
\hline Centromere Position (cM) & 60.7 & 56.9 & 90.6 & 23.1 & 52.2 & \\
\hline Marker Position (cM) & 58.4 & 57.0 & 95.1 & 17.5 & 62.6 & \\
\hline Marker distance to centromere $(\mathrm{cM})$ & 2.2 & 0.1 & 4.5 & 5.6 & 10.4 & \\
\hline Individuals analyzed & \multicolumn{5}{|c|}{ Individual multilocus allelic configuration } & \\
\hline FCSO 05 & $\mathrm{HE}$ & $\mathrm{HE}$ & $\mathrm{HE}$ & $\mathrm{HE}$ & $\mathrm{HE}$ & -6.36 \\
\hline FCSO 12 & $\mathrm{HE}$ & $\mathrm{HE}$ & $\mathrm{HE}$ & $\mathrm{HE}$ & $\mathrm{HE}$ & -6.36 \\
\hline FCSO 13 & $\mathrm{HE}$ & $\mathrm{HE}$ & $\mathrm{HE}$ & $\mathrm{HE}$ & $\mathrm{HE}$ & -6.36 \\
\hline FCSO 27 & $\mathrm{HE}$ & $\mathrm{HE}$ & $\mathrm{HE}$ & $\mathrm{HE}$ & $\mathrm{HE}$ & -6.36 \\
\hline FCSO 33 & $\mathrm{HE}$ & $\mathrm{HE}$ & $\mathrm{HE}$ & $\mathrm{HE}$ & $\mathrm{HE}$ & -6.36 \\
\hline FCSO 36 & $\mathrm{HE}$ & $\mathrm{HE}$ & $\mathrm{HE}$ & $\mathrm{HE}$ & $\mathrm{HE}$ & -6.36 \\
\hline FCSO 58 & $\mathrm{HE}$ & $\mathrm{HE}$ & $\mathrm{HE}$ & $\mathrm{HE}$ & $\mathrm{HE}$ & -6.36 \\
\hline FCSO 59 & $\mathrm{HE}$ & $\mathrm{HE}$ & $\mathrm{HE}$ & $\mathrm{HE}$ & $\mathrm{HE}$ & -6.36 \\
\hline FCSO 02 & $\mathrm{HE}$ & $\mathrm{HE}$ & $\mathrm{HE}$ & $\mathrm{HE}$ & $\mathrm{HO}$ & -4.77 \\
\hline FCSO 09 & $\mathrm{HE}$ & $\mathrm{HE}$ & $\mathrm{HE}$ & $\mathrm{HE}$ & $\mathrm{HO}$ & -4.77 \\
\hline FCSO 20 & $\mathrm{HE}$ & $\mathrm{HE}$ & $\mathrm{HE}$ & $\mathrm{HE}$ & $\mathrm{HO}$ & -4.77 \\
\hline FCSO 21 & $\mathrm{HE}$ & $\mathrm{HE}$ & $\mathrm{HE}$ & $\mathrm{HE}$ & $\mathrm{HO}$ & -4.77 \\
\hline FCSO 01 & $\mathrm{HO}$ & $\mathrm{HE}$ & $\mathrm{HE}$ & $\mathrm{HE}$ & $\mathrm{HE}$ & -4.30 \\
\hline FCSO 11 & $\mathrm{HO}$ & $\mathrm{HE}$ & $\mathrm{HE}$ & $\mathrm{HE}$ & $\mathrm{HE}$ & -4.30 \\
\hline FCSO 19 & $\mathrm{HO}$ & $\mathrm{HE}$ & $\mathrm{HE}$ & $\mathrm{HE}$ & $\mathrm{HE}$ & -4.30 \\
\hline FCSO 23 & $\mathrm{HO}$ & $\mathrm{HE}$ & $\mathrm{HE}$ & $\mathrm{HE}$ & $\mathrm{HE}$ & -4.30 \\
\hline FCSO 29 & $\mathrm{HO}$ & $\mathrm{HE}$ & $\mathrm{HE}$ & $\mathrm{HE}$ & $\mathrm{HE}$ & -4.30 \\
\hline FCSO 37 & $\mathrm{HO}$ & $\mathrm{HE}$ & $\mathrm{HE}$ & $\mathrm{HE}$ & $\mathrm{HE}$ & -4.30 \\
\hline FCSO 38 & $\mathrm{HO}$ & $\mathrm{HE}$ & $\mathrm{HE}$ & $\mathrm{HE}$ & $\mathrm{HE}$ & -4.30 \\
\hline FCSO 45 & $\mathrm{HO}$ & $\mathrm{HE}$ & $\mathrm{HE}$ & $\mathrm{HE}$ & $\mathrm{HE}$ & -4.30 \\
\hline FCSO 07 & $\mathrm{HE}$ & $\mathrm{HE}$ & $\mathrm{HE}$ & $\mathrm{HO}$ & $\mathrm{HE}$ & -4.10 \\
\hline FCSO 08 & $\mathrm{HE}$ & $\mathrm{HE}$ & $\mathrm{HE}$ & $\mathrm{HO}$ & $\mathrm{HE}$ & -4.10 \\
\hline FCSO 25 & $\mathrm{HE}$ & $\mathrm{HE}$ & $\mathrm{HO}$ & $\mathrm{HE}$ & $\mathrm{HE}$ & -3.88 \\
\hline FCSO 43 & $\mathrm{HE}$ & $\mathrm{HE}$ & $\mathrm{HO}$ & $\mathrm{HE}$ & $\mathrm{HE}$ & -3.88 \\
\hline FCSO 44 & $\mathrm{HE}$ & $\mathrm{HE}$ & HO & $\mathrm{HE}$ & $\mathrm{HE}$ & -3.88 \\
\hline FCSO 06 & $\mathrm{HO}$ & $\mathrm{HE}$ & $\mathrm{HE}$ & $\mathrm{HE}$ & $\mathrm{HO}$ & -2.70 \\
\hline FCSO 18 & $\mathrm{HO}$ & $\mathrm{HE}$ & $\mathrm{HE}$ & $\mathrm{HE}$ & $\mathrm{HO}$ & -2.70 \\
\hline FCSO 39 & $\mathrm{HO}$ & $\mathrm{HE}$ & $\mathrm{HE}$ & $\mathrm{HE}$ & $\mathrm{HO}$ & -2.70 \\
\hline FCSO 46 & $\mathrm{HO}$ & $\mathrm{HE}$ & $\mathrm{HE}$ & $\mathrm{HE}$ & $\mathrm{HO}$ & -2.70 \\
\hline FCSO 52 & HO & $\mathrm{HE}$ & $\mathrm{HE}$ & $\mathrm{HE}$ & $\mathrm{HO}$ & -2.70 \\
\hline FCSO 54 & $\mathrm{HO}$ & $\mathrm{HE}$ & $\mathrm{HE}$ & $\mathrm{HE}$ & $\mathrm{HO}$ & -2.70 \\
\hline FCSO 16 & $\mathrm{HE}$ & $\mathrm{HE}$ & $\mathrm{HE}$ & $\mathrm{HO}$ & HO & -2.51 \\
\hline FCSO 40 & $\mathrm{HE}$ & $\mathrm{HE}$ & $\mathrm{HO}$ & $\mathrm{HE}$ & $\mathrm{HO}$ & -2.28 \\
\hline FCSO 41 & $\mathrm{HE}$ & $\mathrm{HE}$ & $\mathrm{HO}$ & $\mathrm{HE}$ & $\mathrm{HO}$ & -2.28 \\
\hline FCSO 47 & $\mathrm{HE}$ & $\mathrm{HE}$ & $\mathrm{HO}$ & $\mathrm{HE}$ & $\mathrm{HO}$ & -2.28 \\
\hline FCSO 56 & $\mathrm{HO}$ & $\mathrm{HE}$ & $\mathrm{HO}$ & $\mathrm{HE}$ & $\mathrm{HE}$ & -1.82 \\
\hline FCSO 42 & $\mathrm{HE}$ & $\mathrm{HE}$ & $\mathrm{HO}$ & $\mathrm{HO}$ & $\mathrm{HE}$ & -1.62 \\
\hline FCSO 17 & $\mathrm{HO}$ & $\mathrm{HE}$ & $\mathrm{HE}$ & $\mathrm{HO}$ & $\mathrm{HO}$ & -0.44 \\
\hline FCSO 50 & $\mathrm{HO}$ & $\mathrm{HE}$ & $\mathrm{HE}$ & $\mathrm{HO}$ & $\mathrm{HO}$ & -0.44 \\
\hline FCSO 48 & $\mathrm{HO}$ & $\mathrm{HE}$ & $\mathrm{HO}$ & $\mathrm{HE}$ & $\mathrm{HO}$ & -0.22 \\
\hline FCSO 22 & $\mathrm{HE}$ & $\mathrm{HE}$ & $\mathrm{HO}$ & $\mathrm{HO}$ & $\mathrm{HO}$ & -0.02 \\
\hline FCSO 35 & $\mathrm{HE}$ & $\mathrm{HO}$ & $\mathrm{HE}$ & $\mathrm{HE}$ & $\mathrm{HO}$ & 0.94 \\
\hline FCSO 53 & $\mathrm{HE}$ & $\mathrm{HO}$ & $\mathrm{HE}$ & $\mathrm{HE}$ & $\mathrm{HO}$ & 0.94 \\
\hline FCSO 32 & $\mathrm{HO}$ & $\mathrm{HO}$ & $\mathrm{HE}$ & $\mathrm{HE}$ & $\mathrm{HE}$ & 1.41 \\
\hline FCSO 60 & $\mathrm{HO}$ & $\mathrm{HE}$ & $\mathrm{HO}$ & $\mathrm{HO}$ & $\mathrm{HO}$ & 2.04 \\
\hline FCSO 24 & $\mathrm{HE}$ & $\mathrm{HO}$ & $\mathrm{HO}$ & $\mathrm{HE}$ & $\mathrm{HO}$ & 3.43 \\
\hline FCSO 51 & $\mathrm{HE}$ & $\mathrm{HO}$ & $\mathrm{HO}$ & $\mathrm{HO}$ & $\mathrm{HE}$ & 4.09 \\
\hline FCSO 15 & $\mathrm{HO}$ & $\mathrm{HO}$ & $\mathrm{HE}$ & $\mathrm{HO}$ & $\mathrm{HO}$ & 5.27 \\
\hline FCSO 34 & $\mathrm{HO}$ & $\mathrm{HO}$ & $\mathrm{HE}$ & $\mathrm{HO}$ & $\mathrm{HO}$ & 5.27 \\
\hline FCSO 04 & $\mathrm{HO}$ & $\mathrm{HO}$ & $\mathrm{HO}$ & $\mathrm{HE}$ & $\mathrm{HO}$ & 5.49 \\
\hline FCSO 26 & $\mathrm{HO}$ & $\mathrm{HO}$ & $\mathrm{HO}$ & $\mathrm{HE}$ & $\mathrm{HO}$ & 5.49 \\
\hline FCSO 31 & $\mathrm{HO}$ & $\mathrm{HO}$ & $\mathrm{HO}$ & $\mathrm{HO}$ & $\mathrm{HE}$ & 6.15 \\
\hline FCSO 28 & $\mathrm{HO}$ & $\mathrm{HO}$ & $\mathrm{HO}$ & $\mathrm{HO}$ & $\mathrm{HO}$ & 7.75 \\
\hline FCSO 57 & $\mathrm{HO}$ & $\mathrm{HO}$ & $\mathrm{HO}$ & $\mathrm{HO}$ & $\mathrm{HO}$ & 7.75 \\
\hline \multicolumn{6}{|c|}{ Population LOD } & -98.29 \\
\hline
\end{tabular}

LODs $>2$ are significant for SDR, LODs> -2 are significant for FDR and, LODs between 2 and -2 do not allow to conclude between SDR and FDR hypoteses . cM Centimorgans, HO Homozygous and HE heterozygous 
For nine plants displaying LOD values between -2 and 2 , it was not possible to conclude between SDR and FDR hypotheses. At population level, LOD values were 35.17 and -98.29 for MCSO and FCSO hybridizations, respectively. Taking together both hybridizations, out of the 64 unreduced pollen gametes produced by diploid 'CSO' tangor, $41(64.1 \%)$ were obtained by FDR, 12 (18.8\%) were significant for SDR, and eleven (17.2\%) yielded non-conclusive results.

For the analysis of the evolution of PHR percentages along the LG2, unreduced pollen gamete populations were classified as significant for SDR or FDR according to their LOD values. Then, they were analyzed with four SSR markers (mCrCIR04H06, Cx6F23, mCrCIR03C08 and CIBE6006) and one SNP marker (2p21022555) (Figure 1.3.). FDR progeny consisted in $412 \mathrm{n}$ pollen gametes; 06 and 35 from MCSO and FCSO hybridizations, respectively, and SDR progeny included 12 unreduced pollen gametes, 02 from the MCSO hybridization and 10 from the FCSO hybridization. For heterozygous loci for the parent producing the $2 n$ gamete, the probabilities of a $2 n$ gamete being heterozygous or homozygous as a consequence of FDR or SDR mechanisms are direct functions of the marker-centromere distance (Park et al., 2007). For heterozygous markers close to the centromere, FDR-2n gametes will be heterozygous and SDR-2n gametes will be homozygous but when crossing over takes place between centromere and the considered locus, FDR-2n gametes will be $50 \%$ heterozygous and 50\% homozygous, but all these loci will be heterozygous in SDR gametes (Park et al., 2007). Forty of 41 FDR-2n pollen gametes analyzed displayed heterozygous allelic configuration for markers close to the centromere (CX6F23 SSR makers and 2p21022555 SNP marker located at 7.3 and $0.1 \mathrm{cM}$ from left and right side of the centromere, respectively) whereas with the telomeric markers, 17 of the FDR-2n pollen gametes displayed homozygous allelic configurations. For SDR-2n pollen gametes, ten over 12 SDR-pollen gametes displayed homozygous allelic configurations for $2 \mathrm{p} 21022555 \mathrm{SNP}$ marker located at $0.1 \mathrm{cM}$ from the centromere whereas with markers located between 7.3 and $67.1 \mathrm{cM}$ from the centromere, 09 of $12 \mathrm{SDR}-2 \mathrm{n}$ pollen gametes displayed heterozygosity.

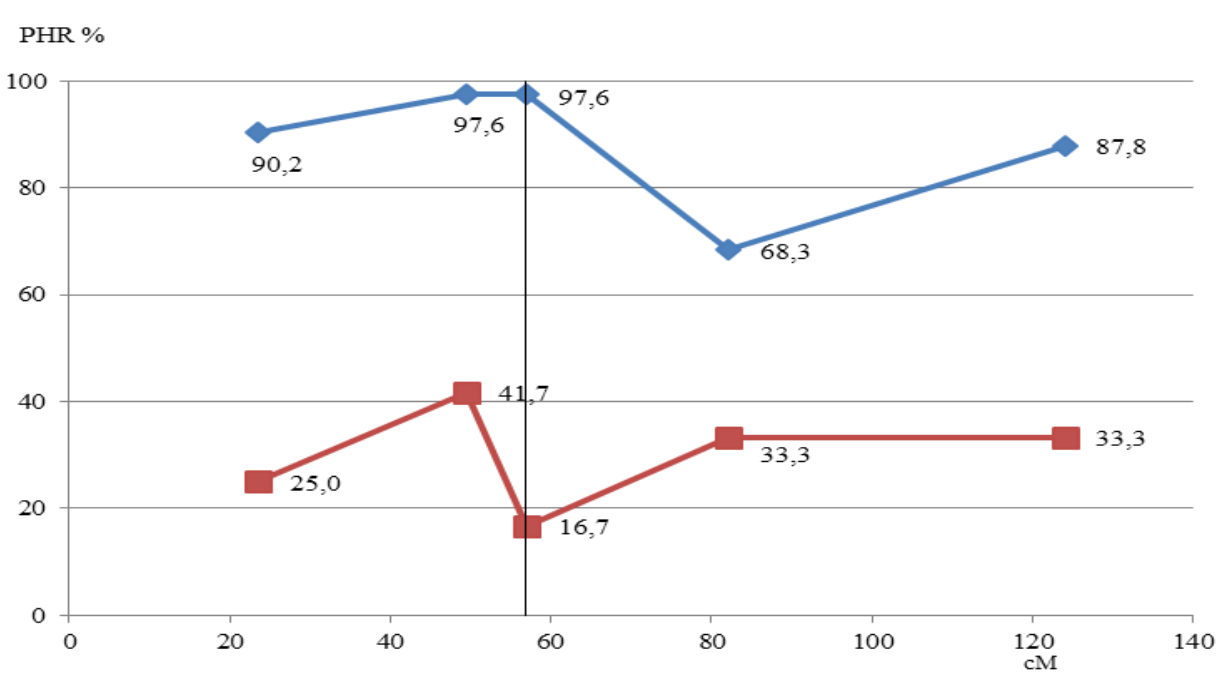

Figure 1.3. Observed parental heterozygosity restitution values for $2 \mathrm{n}$ pollen gametes classified by mechanism of unreduced gamete formation for markers in LG 2. Positions, according to clementine genetic map (Ollitrault et al., 2012). Blue line corresponds to FDR and red line corresponds to SDR mechanism and vertical line corresponds with the centromere location (Aleza et al., 2015). 
Regarding the FDR population, PHR value increases from $90.2 \%$ for the mCrCIR04H06 marker (located in one telomere) to $97.6 \%$ for the CX6F23 and 2p21022555 centromeric markers. Subsequently, PHR value decreased to68.3\% for the mCrCIR03C08 marker (at $25,3 \mathrm{cM}$ from the centromere) and increased again to $87.8 \%$ for the CIBE6006 telomeric marker (Figure 1.3). The average of PHR for FDR-2n gamete population was $88.29 \%$. Considering all the $2 \mathrm{n}$ gametes with LOD significant for SDR, the PHR increases from $25 \%$ for the mCrCIR04H06 telomeric marker to $41.7 \%$ for the CX6F23 marker and decreases to $16.7 \%$ for the $2 \mathrm{p} 21022555$ centromeric marker. Also, the PHR value increases again to $33 \%$ for the remaining two markers. The average of PHR for SDR-2n gamete population was 30\%. Assuming that a random distribution of heterozygous loci along the chromosomes occurred, global restitution of heterozygosity is expected to be near $80 \%$ for FDR and $40 \%$ for SDR (Peloquin, 1983; Hutten et al. 1994; Carputo et al., 2003). In a previous work (Aleza et al., 2015), the maternal heterozygosity restitution average produced by clementine SDR-2n gametes was $42.5 \%$. The present results obtained for FDR-2n pollen gametes are in agreement with those obtained in potato (Peloquin, 1983; Hutten et al., 1994; Carputo et al., 2003) whereas for the SDR-2n pollen gametes, the average restitution is lower than those expected. Considering the low number of markers and SDR individuals analyzed, this average could be considered as normal for a SDR gamete population.

This is the first report in Citrus of coexistence of two different meiotic restitution mechanisms (SDR and FDR) producing unreduced pollen in the same genotype. FDR appeared predominant in the studied $2 \mathrm{n}$ pollen, while SDR have been identified as the main mechanism of 2 n megagametophytes in mandarins. Cuenca et al. (2015) analyzed 543 triploid hybrids obtained from nineteen different genotypes of mandarins and only three triploid plants were obtained by FDR-2n female gametes and no $2 \mathrm{n}$ pollen gametes contributed to the production of triploid hybrids. In a 'Nishiuchi Konatsu', a Japanese mandarin (C. tamurana), Honsho et al. (2016) reported the production of pollen grains with different sizes. They demonstrated that the biggest pollen grains were diploid resulting from FDR, although no progenies were recovered. In potato, genotypes that produce FDR-2npollen gametes and SDR-2n female gametes and genotypes that produce a mixture of SDR and FDR-2n female gametes have been described (Hutten $e t$ al., 1994). Such variability of mechanism of $2 \mathrm{n}$ gamete production has also been observed in other woody specie like Populus L. Liesebach et al. (2015) observed that 2n male gametes were originated by both mechanisms in similar frequencies. However, frequencies from $2 \mathrm{n}$ female gametes were uncoupled with a strong deviation to SDR. Most alleles conferring sexual polyploidization appear to be highly sex specific, indicating that unreduced gamete formation in male and female sporogenesis are largely uncoupled (Bretagnolle and Thompson, 1995; De Storme and Geelen, 2013).

\section{Implications for polyploid breeding programs}

The Citrus genus can be used as a model for meiosis, unreduced gamete mechanism studies, and polyploid research (Ollitrault et al., 2008; Cuenca et al., 2015; Aleza et al., $2009 \mathrm{~b} ; 2016 \mathrm{a})$. The associated development of molecular and cytological techniques will lead to rapid advancements in the field in coming years (De Storme and Geelen, 2013). The breeding value of sexual polyploidy has been convincingly demonstrated in the case of potato (Peloquin, 1982), alfalfa (Bingham and McCoy, 1979) and red clover (Parrot et al., 1985) among other crops. 
Determination of mechanisms underlying $2 \mathrm{n}$ pollen formation is a key result for breeding programs based onploidy manipulation. Indeed the different mechanisms imply major differences in the genetic structure of triploid progenies and hence, in the efficiency of breeding schemes. Several previous publications discussed the relative advantages of SDR and FDR gametes in polyploid breeding (Mendiburu and Peloquin, 1977a, b; Hutten et al., 1994). Genetic and economic importance of any obtained population goes through its genetic structure in relation with the objectives of the breeding program. For example, if the objective is to create progenies more similar to the parent producing the unreduced gamete, FDR-2n gametes will be a better strategy because the resulting $2 \mathrm{n}$ gametes will be heterozygous as their parent from the centromere to the first crossing over. Therefore $2 \mathrm{n}$ gametes retain most parental heterozygosity and epistatic interactions as it has been demonstrated in potato by Mendiburu and Peloquin (1977a, b). On the contrary, SDR-2n gametes provide the opportunity to create a larger number of new multilocus genotypic combinations and a higher number of polymorphic progenies, providing new products that meet commercial market segmentation strategies (Cuenca et al., 2011; Aleza et al., 2016a).

The main strategies used to create triploid hybrids in citrus are sexual polyploidization by $2 \mathrm{n}$ gametes, as has been discussed above, and interploid sexual hybridizations using tetraploid parents (doubled diploids, DD) (Aleza et al., 2010b; 2012a, b). Aleza et al. (2016a) demonstrated the complementarity of diploid gamete population produced by a DD clementine displaying a predominant tetrasomic segregation (PHR average around $65 \%$ ) and SDR-2n gametes of clementine with less PHR value. The distribution of PHR along each chromosome was also different. In SDR-2n pollen gametes, loci between the centromere and the first crossover are homozygous, but parental heterozygosity restitution is favored for the telomeric loci. By contrast, PHR is relatively constant across a chromosome for DD gametes with genotypic combinations that are closer to clementine. In the present study, the UPGMA analysis of the 41 FDR $2 \mathrm{n}$ pollen and 12 SDR $2 \mathrm{n}$ pollen based on the five markers of LG2 clearly displayed differentiated clusters between FDR and SDR-2n pollen (Figure 1.4) and an even higher differentiation than the one revealed by Aleza et al. (2016a) between DD Clementine gametes and SDR 2n gametes. Indeed, for FDR-2n gametes the PHR is higher than the one obtained with a doubled-diploid parent and pattern of PHR along a chromosome are opposed between FDR and SDR. For FDR, loci between the centromere and the first crossover are heterozygous, and half of the parental heterozygous loci beyond the first crossing over are also heterozygous. Thus, with the objective to develop new citrus cultivars that are phenotypically close to one parent, the exploitation of $2 \mathrm{n}$ FDR pollen in diploid crosses should be the best strategy; followed by interploid hybridization with a DD of the considered parent. The exploitation of SDR $2 \mathrm{n}$ pollen or ovules will produce more polymorphic progenies and should be more adapted to new product selection and market segmentation strategies. The tetraploid plants obtained in $4 \mathrm{x} \times 2 \mathrm{x}$ hybridization may be used as parents for further triploid breeding. The ones arising from FDR should be more interesting to provide increased gametic diversity and heterosis due to their higher level of heterozygosity, particularly in centromeric regions. 


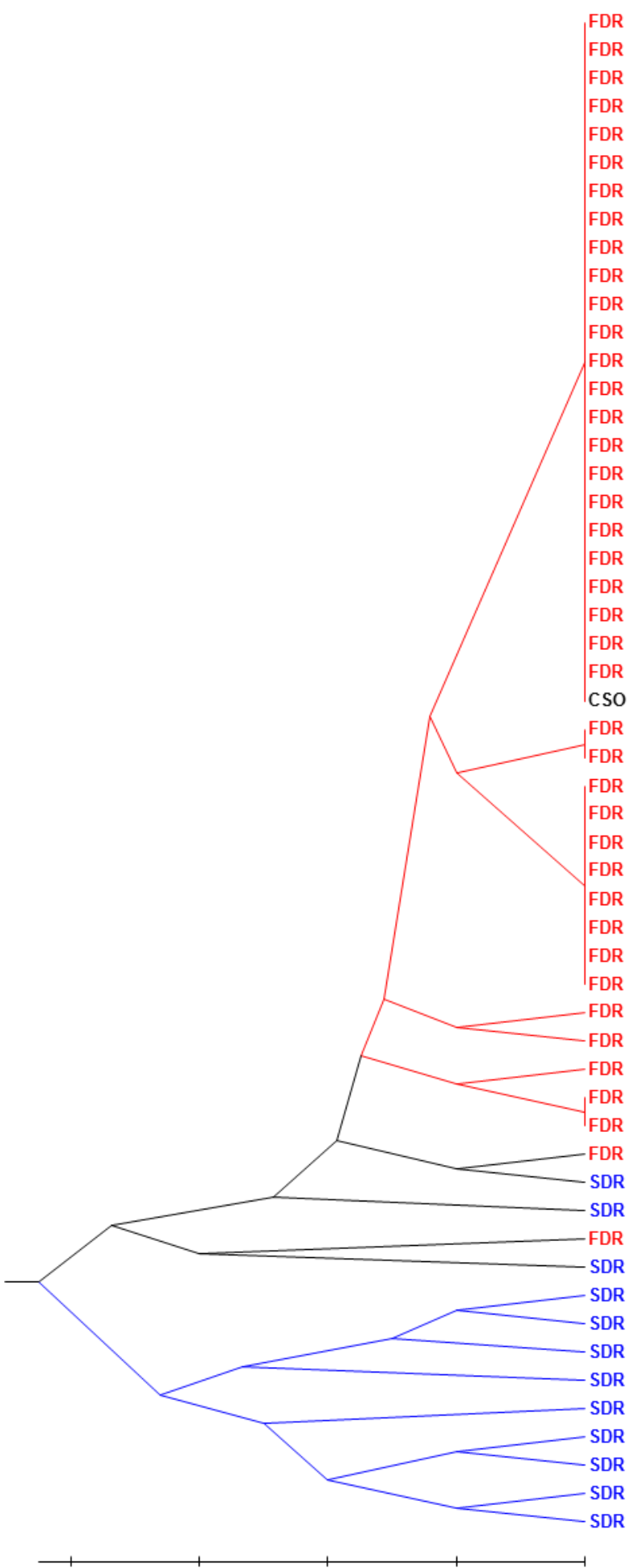

Figure 1.4. UPGMA tree obtained from allelic data of $2 n$ pollen gametes produced by the diploid 'CSO' tangor (black) originated by FDR (red) and SDR (blue) mechanisms. 


\section{Conclusion}

SSR and SNP analysis revealed that $89 \%$ of 72 tetraploid hybrids obtained in $4 \mathrm{x} \times 2 \mathrm{x}$ hybridization using CSO tangor as male parents resulted from $2 \mathrm{n}$ pollen of CSO. Maximum likelihood method based on PHR of centromeric loci was applied to determine the FDR or SDR origin at individual level. Among the 53 plants with conclusive results FDR was the predominant mechanism (77\%), but $23 \%$ of SDR deriving plants were also identified. To our knowledge, this is the first report for citrus of tetraploid progenies arising from unreduced pollen and the first description of the coexistence of two meiotic restitution mechanisms (SDR and FDR) producing unreduced pollen. Progenies arising from FDR and SDR pollen displayed complementary genetic diversity. FDR pollen should be more efficient to develop new cultivars closer to the pollen parent while SDR should allow developing more polymorphic progeny with the perspective of selection of new products. 


\section{Supplementary information}

Additional table 1.1. Evidence of the origin by selfertilisation of tetraploid clementine for eight progenies.

Table 1.1.a. Allelic configuration of the eight tetraploid plants recovered from selfpollination of tetraploid 'Fina' clementine.

\begin{tabular}{|c|c|c|c|c|c|c|c|c|c|c|c|c|c|c|c|c|}
\hline \multirow{2}{*}{$\frac{\text { Individuals }}{\text { 4x ‘Fina’ clementine }}$} & \multicolumn{4}{|c|}{ CIBE5720 } & \multicolumn{4}{|c|}{ mCrCIR04H06 } & \multicolumn{4}{|c|}{ CX6F23 } & \multicolumn{4}{|c|}{ mCrCIR03C08 } \\
\hline & 325 & 325 & 33 & $7 \quad 337$ & 190 & 190 & 196 & 196 & 149 & 149 & 161 & 161 & 208 & 208 & 226 & 226 \\
\hline $2 \mathrm{x}^{`} \mathrm{CSO}^{\prime}$ & 325 & 340 & & & 184 & 196 & & & 155 & 161 & & & 208 & 212 & & \\
\hline FCSO 61 & 325 & 325 & 337 & $7 \quad 337$ & 190 & 196 & 196 & 196 & 149 & 161 & 161 & 161 & 208 & 208 & 208 & 226 \\
\hline FCSO 62 & 325 & 325 & 33 & $7 \quad 337$ & 190 & 196 & 196 & 196 & 149 & 161 & 161 & 161 & 208 & 208 & 226 & 226 \\
\hline FCSO 63 & 325 & 325 & 33 & $7 \quad 337$ & 190 & 190 & 196 & 196 & 149 & 149 & 161 & 161 & 208 & 208 & 208 & 226 \\
\hline FCSO 64 & 325 & 325 & 33 & $7 \quad 337$ & 190 & 190 & 196 & 196 & 161 & 161 & 161 & 161 & 208 & 208 & 208 & 226 \\
\hline FCSO 65 & 325 & 325 & 33 & $7 \quad 337$ & 190 & 190 & 196 & 196 & 149 & 161 & 161 & 161 & 208 & 208 & 208 & 208 \\
\hline FCSO 66 & 325 & 325 & 337 & $7 \quad 337$ & 190 & 196 & 196 & 196 & 149 & 161 & 161 & 161 & 208 & 208 & 226 & 226 \\
\hline FCSO 67 & 325 & 325 & 33 & $7 \quad 337$ & 190 & 196 & 196 & 196 & 149 & 161 & 161 & 161 & 208 & 208 & 208 & 226 \\
\hline FCSO 68 & 325 & 325 & 33 & $7 \quad 337$ & 190 & 196 & 196 & 196 & 149 & 149 & 161 & 161 & 208 & 208 & 226 & 226 \\
\hline Individuals & \multicolumn{4}{|c|}{$2 \mathrm{p} 21022555$} & \multicolumn{4}{|c|}{ CIBE6006 } & \multicolumn{4}{|c|}{$3 p 35931624$} & \multicolumn{4}{|c|}{ 5AT21 } \\
\hline $4 x^{`} F^{\prime} a^{\prime}$ clementine & A & A & A & A & 176 & 176 & 200 & 200 & G & G & Gr & G & 254 & 254 & 254 & 254 \\
\hline $2 \mathrm{x}^{`} \mathrm{CSO}^{\prime}$ & $\mathbf{T}$ & $\mathbf{A}$ & & & 197 & 200 & & & G & $\mathbf{A}$ & & & 240 & 254 & & \\
\hline FCSO 61 & A & A & A & A & 176 & 176 & 200 & 200 & G & G & G & G & 254 & 254 & 254 & 254 \\
\hline FCSO 62 & A & A & A & A & 176 & 200 & 200 & 200 & G & G & G & G & 254 & 254 & 254 & 254 \\
\hline FCSO 63 & A & A & A & A & 176 & 200 & 200 & 200 & G & G & G & G & 254 & 254 & 254 & 254 \\
\hline FCSO 64 & A & A & A & A & 176 & 200 & 200 & 200 & G & G & G & G & 254 & 254 & 254 & 254 \\
\hline FCSO 65 & A & A & A & A & 176 & 176 & 200 & 200 & G & G & G & G & 254 & 254 & 254 & 254 \\
\hline FCSO 66 & A & A & A & A & 176 & 200 & 200 & 200 & G & G & G & G & 254 & 254 & 254 & 254 \\
\hline FCSO 67 & A & A & A & A & 176 & 200 & 200 & 200 & G & G & G & G & 254 & 254 & 254 & 254 \\
\hline FCSO 68 & A & A & A & A & 176 & 200 & 200 & 200 & G & G & G & G & 254 & 254 & 254 & 254 \\
\hline Individuals & & 9TA & A22 & & & $\mathrm{CrCIR}$ & $\mathrm{R} 01 \mathrm{C} 0$ & & & $\mathrm{TC}$ & & & & & & \\
\hline $4 x^{`}$ Fina' clementine $^{\prime}$ & 150 & 150 & 203 & 203 & 133 & 133 & 165 & 165 & 333 & 333 & 348 & 348 & & & & \\
\hline $2 \mathrm{x}^{`} \mathrm{CSO}^{\prime}$ & 164 & 203 & & & 159 & 165 & & & 333 & 351 & & & & & & \\
\hline FCSO 61 & 150 & 150 & 203 & 203 & 133 & 133 & 165 & 165 & 333 & 333 & 348 & 348 & & & & \\
\hline FCSO 62 & 150 & 150 & 203 & 203 & 133 & 133 & 165 & 165 & 333 & 333 & 333 & 348 & & & & \\
\hline FCSO 63 & 150 & 150 & 203 & 203 & 133 & 165 & 165 & 165 & 333 & 333 & 348 & 348 & & & & \\
\hline FCSO 64 & 150 & 150 & 203 & 203 & 133 & 133 & 165 & 165 & 333 & 333 & 333 & 348 & & & & \\
\hline FCSO 65 & 150 & 150 & 203 & 203 & 133 & 133 & 165 & 165 & 333 & 333 & 348 & 348 & & & & \\
\hline FCSO 66 & 203 & 203 & 203 & 203 & 133 & 133 & 165 & 165 & 333 & 333 & 348 & 348 & & & & \\
\hline FCSO 67 & 203 & 203 & 203 & 203 & 133 & 133 & 165 & 165 & 333 & 333 & 348 & 348 & & & & \\
\hline FCSO 68 & 150 & 150 & 203 & 203 & 133 & 133 & 165 & 165 & 333 & 333 & 348 & 348 & & & & \\
\hline
\end{tabular}

Numbers indicate the size of alleles in nucleotides (nt). Squares painted in green indicate the presence of sexual recombination and testify that the tetraploid plants do not arise from nucellar embryony (apomixis).

The specific alleles of the 'CSO' hybrid (in red) were never observed in these eight tetraploid plants (Table 1.1.b). 
For loci close to the centromere, according to the distance to the centromere (d) of each marker and the function of heterozzygosity restitution under total interference model (Cuenca et al., 2015) we estimated the probability that the common allele with Clementine (CA) pass in homozygosity trough FDR or SDR 2 n gametes as following:

$\operatorname{PFDR}(\mathrm{CA})=\mathrm{d} / 2$

$\operatorname{PSDR}(\mathrm{CA})=0.5-\mathrm{d}$

For telomeric loci we considered the thresold of $2 / 3$ for heterozygosity restitution obtained for no interference and partial interference models under SDR and FDR mechanisms (Cuenca et al., 2011)

Therefore for telomeric markers:

$\operatorname{PFDR}(\mathrm{CA})=1 / 6$

$\operatorname{PSDR}(\mathrm{CA})=1 / 6$

We considered 5 independant centromeric loci (in different chromosomes) and 2 telomeric independant loci (Table 1.1.b).

Table 1.1.b. Probability of transmission of the 'CSO' specific allele through unreduced gametes.

Markers $\quad$ CiBE6006 TC01 5 5AT21 CiBE5720 9TAA22 2p21022555 mCrCIR01C06 $\begin{gathered}\text { Total } \\ \text { Probability }\end{gathered}$

\begin{tabular}{|c|c|c|c|c|c|c|c|c|}
\hline LG & 2 & 3 & 5 & 1 & 9 & 2 & 6 & \\
\hline $\begin{array}{l}\text { Centromere } \\
\text { Position }\end{array}$ & 0.569 & 0.906 & 0.231 & 0.607 & 0.522 & 0.569 & 0.064 & \\
\hline Marker Position & 1.240 & 0.960 & 0.175 & 0.584 & 0.626 & 0.570 & 0.889 & \\
\hline Distance & 0.671 & 0.054 & 0.056 & 0.023 & 0.104 & 0.001 & 0.825 & \\
\hline Prob He SDR & 0.667 & 0.108 & 0.112 & 0.045 & 0.208 & 0.003 & 0.667 & \\
\hline Prob Ho SDR & 0.333 & 0.892 & 0.888 & 0.955 & 0.792 & 0.997 & 0.333 & \\
\hline $\begin{array}{l}\text { Prob Ho SDR } \\
\text { specific allele }\end{array}$ & 0.167 & 0.446 & 0.444 & 0.477 & 0.396 & 0.499 & 0.167 & $5.18 \mathrm{E}-04$ \\
\hline Prob He FDR & 0.667 & 0.946 & 0.944 & 0.977 & 0.896 & 0.999 & 0.667 & \\
\hline Prob Ho FDR & 0.333 & 0.054 & 0.056 & 0.023 & 0.104 & 0.001 & 0.333 & \\
\hline $\begin{array}{l}\text { Prob Ho FDR } \\
\text { specific allele }\end{array}$ & 0.167 & 0.027 & 0.028 & 0.011 & 0.052 & 0.001 & 0.167 & $8.03 E-12$ \\
\hline
\end{tabular}

Under the hypothesis of cross pollination with ' $\mathrm{CSO}^{\prime} 2 \mathrm{n}$ gametes arising from FDR or SDR, the probabilities to observe, at individual level, such configurations without the 'CSO' specific alleles are respectively $\mathrm{P}=8.03 \mathrm{E}-12$ and $\mathrm{P}=5.18 \mathrm{E}-04$. Therefore the hypothesis of cross-pollination with ' $\mathrm{CSO}^{\prime} 2 \mathrm{n}$ gametes can be rejected for these plants. 
Additional Table 1.2. Analysis at individual and population level of the origin of 'CSO' tangor 2n gametes recovered from DD 'Moncada' mandarin by 'CSO' diploid tangor sexual hybridization using markers close to the centromeres of all LGs and the LOD score test probability ratio for SDR/FDR.

\begin{tabular}{|c|c|c|c|c|c|c|c|c|c|c|c|}
\hline $\begin{array}{l}\text { Closest marker to the } \\
\text { centromere }\end{array}$ & MEST539 & CX6F23 & TC01 & CF-ACA01 & 5AT21 & CiC4356-06 & Ci07C07 & LCY2-M-376 & 9AAT22 & \multirow{7}{*}{ LOD (SDR/FDR) } & \multirow{7}{*}{ Conclusion } \\
\hline LG & 1 & 2 & 3 & 4 & 5 & 6 & 7 & 8 & 9 & & \\
\hline Centromere Position (cM) & 60,7 & 56,9 & 90,6 & 16,1 & 23,1 & 6,4 & 96,4 & 54,2 & 52,2 & & \\
\hline Marker Position (cM) & 61,8 & 49,5 & 96,0 & 24,4 & 17,5 & 6,2 & 98,0 & 58,1 & 62,6 & & \\
\hline $\begin{array}{l}\text { Marker distance to } \\
\text { centromere }(\mathrm{cM})\end{array}$ & 1,2 & 7,3 & 5,4 & 8,3 & 5,6 & 0,2 & 1,6 & 3,9 & 10,4 & & \\
\hline CSO genotype & 104108 & 155161 & 333352 & 336340 & 240254 & $\mathrm{CT}$ & 227240 & $\mathrm{AG}$ & 163202 & & \\
\hline Individuals analyzed & \multicolumn{9}{|c|}{ Multilocus allelic configuration of the CSO 2n gametes } & & \\
\hline MCSO 03 & 104108 & 155161 & 333352 & 336340 & 240254 & $\mathrm{CT}$ & 227240 & A G & 163202 & $-8,28$ & FDR \\
\hline MCSO 09 & 104108 & 155161 & 333352 & 336340 & 240254 & $\mathrm{C} \mathrm{T}$ & 227240 & A G & 163202 & $-8,28$ & FDR \\
\hline MCSO 05 & 104108 & 155161 & 333352 & 336340 & 240254 & $\mathrm{C} \mathrm{T}$ & 227240 & $\mathrm{~A} \mathrm{G}$ & 163163 & $-6,68$ & FDR \\
\hline MCSO 08 & 104108 & 155161 & 333352 & 336340 & 240254 & $\mathrm{CT}$ & 227240 & $\mathrm{~A} \mathrm{~A}$ & 163202 & $-6,40$ & FDR \\
\hline MCSO 10 & 104104 & 155155 & 333352 & 336340 & 240254 & $\mathrm{C} \mathrm{T}$ & 227240 & A G & 163202 & $-5,16$ & FDR \\
\hline MCSO 02 & 104108 & 155161 & 333352 & 336340 & 254254 & $\mathrm{C} \mathrm{T}$ & 227227 & $\mathrm{~A} \mathrm{G}$ & 163202 & $-4,39$ & FDR \\
\hline MCSO 06 & 104108 & 155161 & 333352 & 336340 & 240254 & $\mathrm{CC}$ & 227240 & $\mathrm{~A} \mathrm{~A}$ & 163163 & $-0,96$ & UN \\
\hline MCSO 07 & 104108 & 155155 & 333352 & 336340 & 254254 & $\mathrm{C} \mathrm{C}$ & 227240 & A A & 163202 & 0,30 & $\mathrm{UN}$ \\
\hline MCSO 04 & 104108 & 155161 & 333333 & 340340 & 240240 & $\mathrm{C} \mathrm{T}$ & 240240 & A A & 163202 & 2,06 & SDR \\
\hline MCSO 01 & 104104 & 155155 & 333333 & 336340 & 240240 & $\mathrm{C} \mathrm{T}$ & 240240 & A G & 163163 & 2,62 & SDR \\
\hline \multicolumn{10}{|c|}{ Population LOD } & $-35,17$ & \\
\hline
\end{tabular}

LODs > 2 are significant for SDR, LODs > -2 are significant for FDR and, LODs between 2 and -2 do not allow to conclude between SDR and FDR hypotheses . cM Centimorgans, Numbers indicate the size of alleles in nucleotides (nt) and letters correspond to SNP markers alleles. 
Additional table 1.3. Analysis at individual level of the origin of ' $\mathrm{CSO}^{\prime}$ ' tangor $2 \mathrm{n}$ gametes recovered from DD 'Fina' clementine by ' $\mathrm{CSO}^{\prime}$ ' diploid tangor sexual hybridization using markers close to the centromeres of five different LGs and the LOD score test probability ratio for SDR/FDR.

\begin{tabular}{|c|c|c|c|c|c|c|c|}
\hline $\begin{array}{l}\text { Closest marker } \\
\text { to centromere }\end{array}$ & CIBE5720 & $2 p 21022555$ & $3 p 35931624$ & 5AT21 & 9TAA22 & \multirow{7}{*}{$\begin{array}{l}\text { LOD } \\
\text { (SDR/FDR) }\end{array}$} & \multirow{7}{*}{ 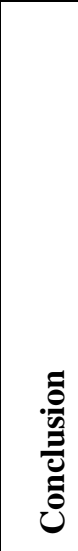 } \\
\hline LG & 1 & 2 & 3 & 5 & 9 & & \\
\hline $\begin{array}{l}\text { Centromere } \\
\text { Position }(\mathrm{cM})\end{array}$ & 60,7 & 56,9 & 90,6 & 23,1 & 52,2 & & \\
\hline $\begin{array}{l}\text { Marker Position } \\
\text { (cM) }\end{array}$ & 58,5 & 57,0 & 95,1 & 17,5 & 62,6 & & \\
\hline $\begin{array}{l}\text { Marker distance } \\
\text { to centromere } \\
\text { (cM) }\end{array}$ & 2,2 & 0,1 & 4,5 & 5,6 & 10,4 & & \\
\hline 'CSO’ genotype & 325340 & AT & GA & 240254 & 164203 & & \\
\hline $\begin{array}{l}\text { Individuals } \\
\text { analyzed }\end{array}$ & \multicolumn{5}{|c|}{ Multilocus allelic configuration of the CSO 2n gametes. } & & \\
\hline FCSO 05 & 325340 & AT & GA & 240254 & 164203 & $-6,36$ & FDR \\
\hline FCSO 12 & 325340 & AT & GA & 240254 & 164203 & $-6,36$ & FDR \\
\hline FCSO 13 & 325340 & AT & GA & 240254 & 164203 & $-6,36$ & FDR \\
\hline FCSO 27 & 325340 & AT & GA & 240254 & 164203 & $-6,36$ & FDR \\
\hline FCSO 33 & 325340 & AT & GA & 240254 & 164203 & $-6,36$ & FDR \\
\hline FCSO 36 & 325340 & AT & GA & 240254 & 164203 & $-6,36$ & FDR \\
\hline FCSO 58 & 325340 & AT & GA & 240254 & 164203 & $-6,36$ & FDR \\
\hline FCSO 59 & 325340 & AT & GA & 240254 & 164203 & $-6,36$ & FDR \\
\hline FCSO 02 & 325340 & AT & GA & 240254 & 203203 & $-4,77$ & FDR \\
\hline FCSO 09 & 325340 & AT & GA & 240254 & 203203 & $-4,77$ & FDR \\
\hline FCSO 20 & 325340 & AT & GA & 240254 & 164164 & $-4,77$ & FDR \\
\hline FCSO 21 & 325340 & AT & GA & 240254 & 203203 & $-4,77$ & FDR \\
\hline FCSO 01 & 325325 & AT & GA & 240254 & 164203 & $-4,30$ & FDR \\
\hline FCSO 11 & 340340 & AT & GA & 240254 & 164203 & $-4,30$ & FDR \\
\hline FCSO 19 & 325325 & AT & GA & 240254 & 164203 & $-4,30$ & FDR \\
\hline FCSO 23 & 340340 & AT & GA & 240254 & 164203 & $-4,30$ & FDR \\
\hline FCSO 29 & 325325 & AT & GA & 240254 & 164203 & $-4,30$ & FDR \\
\hline FCSO 37 & 325325 & AT & GA & 240254 & 164203 & $-4,30$ & FDR \\
\hline FCSO 38 & 325325 & AT & GA & 240254 & 164203 & $-4,30$ & FDR \\
\hline FCSO 45 & 325325 & AT & GA & 240254 & 164203 & $-4,30$ & FDR \\
\hline FCSO 07 & 325340 & AT & GA & 254254 & 164203 & $-4,10$ & FDR \\
\hline FCSO 08 & 325340 & AT & GA & 240240 & 164203 & $-4,10$ & FDR \\
\hline FCSO 25 & 325340 & AT & AA & 240254 & 164203 & $-3,88$ & FDR \\
\hline FCSO 43 & 325340 & AT & AA & 240254 & 164203 & $-3,88$ & FDR \\
\hline FCSO 44 & 325340 & AT & AA & 240254 & 164203 & $-3,88$ & FDR \\
\hline FCSO 06 & 340340 & AT & GA & 240254 & 164164 & $-2,70$ & FDR \\
\hline FCSO 18 & 325325 & AT & GA & 240254 & 203203 & $-2,70$ & FDR \\
\hline FCSO 39 & 340340 & AT & GA & 240254 & 203203 & $-2,70$ & FDR \\
\hline FCSO 46 & 340340 & AT & GA & 240254 & 164164 & $-2,70$ & FDR \\
\hline FCSO 52 & 325325 & AT & GA & 240254 & 203203 & $-2,70$ & FDR \\
\hline FCSO 54 & 340340 & AT & GA & 240254 & 203203 & $-2,70$ & FDR \\
\hline FCSO 16 & 325340 & AT & GA & 254254 & 164164 & $-2,51$ & FDR \\
\hline FCSO 40 & 325340 & AT & AA & 240254 & 164164 & $-2,28$ & FDR \\
\hline FCSO 41 & 325340 & AT & AA & 240254 & 164164 & $-2,28$ & FDR \\
\hline FCSO 47 & 325340 & AT & AA & 240254 & 164164 & $-2,28$ & FDR \\
\hline FCSO 56 & 325325 & AT & AA & 240254 & 164203 & $-1,82$ & UN \\
\hline FCSO 42 & 325340 & AT & AA & 254254 & 164203 & $-1,62$ & UN \\
\hline FCSO 17 & 325325 & AT & GA & 254254 & 203203 & $-0,44$ & UN \\
\hline FCSO 50 & 340340 & AT & GA & 254254 & 203203 & $-0,44$ & UN \\
\hline FCSO 48 & 340340 & AT & AA & 240254 & 203203 & $-0,22$ & UN \\
\hline
\end{tabular}


Additional table 1.3. - cont. Analysis at individual level of the origin of 'CSO' tangor 2n gametes recovered from DD 'Fina' clementine by ' $\mathrm{CSO}^{\prime}$ ' diploid tangor sexual hybridization using markers close to the centromeres of five different LGs and the LOD score test probability ratio for SDR/FDR.

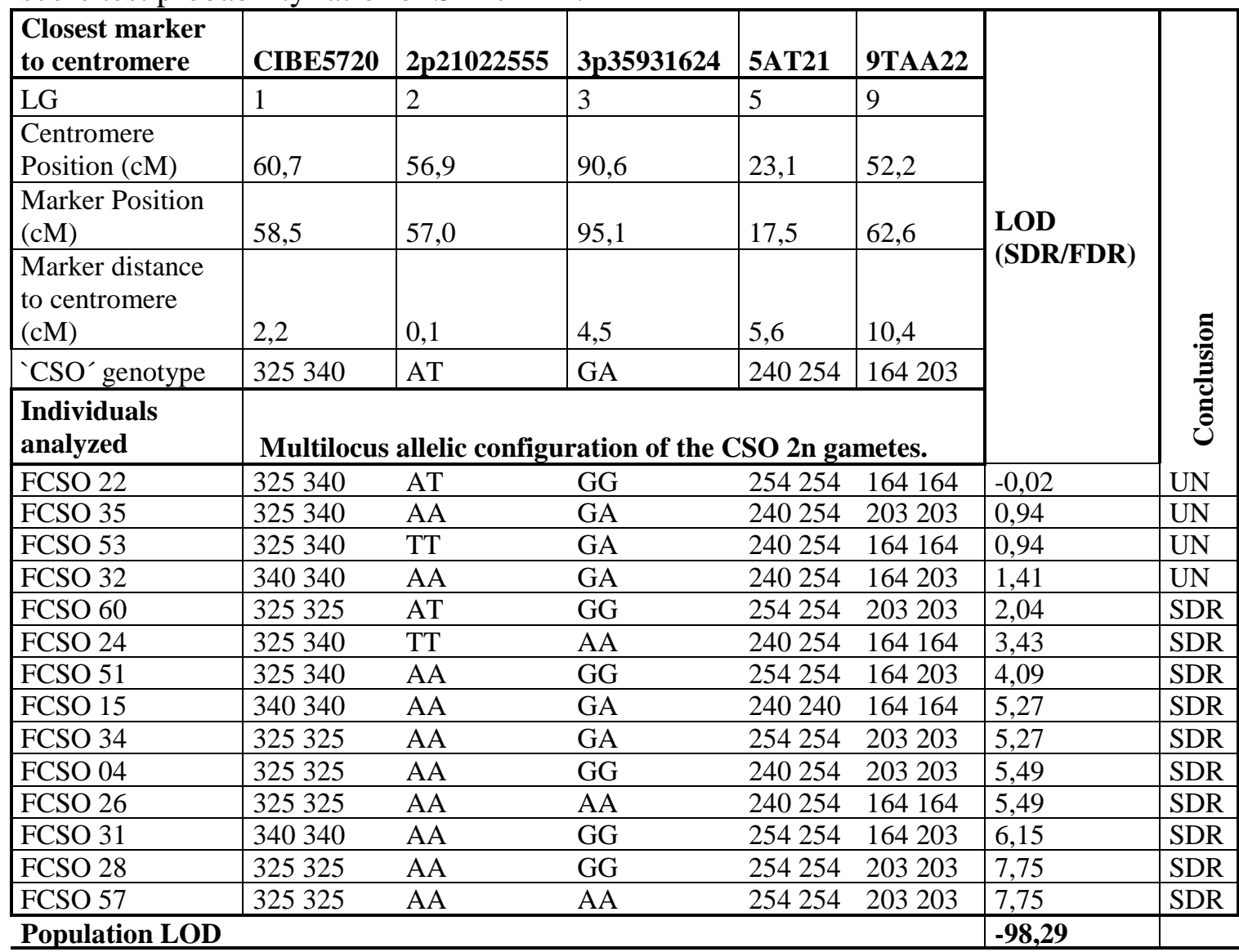

LODs > 2 are significant for SDR, LODs>-2 are significant for FDR and, LODs between 2 and -2 do not allow to conclude between SDR and FDR hypotheses (UN) . cM Centimorgans, Numbers indicate the size of alleles in nucleotides (nt) and letters correspond to SNP markers alleles. 


\section{CHAPTER II}

Unreduced Megagametophyte Production in Lemon Occurs via Three Meiotic Mechanisms, Predominantly Second-Division

Restitution

Houssem Rouiss, José Cuenca, Luis Navarro, Patrick Ollitrault and Pablo Aleza

Frontiers in Plant Science. doi: 10.3389/fpls.2017.01211. 



\section{$\underline{\text { Abstract }}$}

Unreduced (2n) gametes have played a pivotal role in polyploid plant evolution and are useful for sexual polyploid breeding in various species, particularly for developing new seedless citrus varieties. The underlying mechanisms of $2 \mathrm{n}$ gamete formation were recently revealed for Citrus reticulata but remain poorly understood for other citrus species, including lemon $(C$. limon [L.] Burm. f.). We investigated the frequency and causal meiotic mechanisms of $2 \mathrm{n}$ megagametophyte production in lemon. We genotyped 48 progeny plants of two lemon genotypes, 'Eureka Frost' and 'Fino', using 16 Simple Sequence Repeats (SSR) and 18 Single Nucleotide Polymorphism (SNP) markers to determine the genetic origin of the progenies and the underlying mechanisms for $2 \mathrm{n}$ gamete formation. We utilized a maximum-likelihood method based on parental heterozygosity restitution (PHR) of centromeric markers and analysis of PHR patterns along the chromosome. The frequency of $2 \mathrm{n}$ gamete production was $4.9 \%$ for 'Eureka Frost' and $8.3 \%$ for 'Fino', with three meiotic mechanisms leading to $2 \mathrm{n}$ gamete formation. We performed the maximum-likelihood method at the individual level via telomeric marker analysis, finding that $88 \%$ of the hybrids arose from second-division restitution (SDR), 7\% from first-division restitution (FDR) or pre-meiotic doubling (PRD), and 5\% from post-meiotic genome doubling (PMD). The pattern of PHR along LG 1 confirmed that SDR is the main mechanism for $2 \mathrm{n}$ gamete production. Recombination analysis between markers in this LG revealed partial chiasma interference on both arms. We discuss the implications of these restitution mechanisms for citrus breeding and lemon genetics.

\section{Keywords}

Citrus, Unreduced gametes, Meiotic restitution, Second-division restitution (SDR), First-division restitution (FDR), Post-meiotic genome doubling (PMD) mechanisms, Seedlessness 


\section{Introduction}

The exact area of origin of lemon (Citrus limon) is uncertain, but, likely, it originated in Northern India and South East China or in northern Myanmar (Curk et al., 2016). Molecular analyses indicate that this species resulted from direct hybridization between $C$. aurantium (sour orange) as the female parent and $C$. medica (citron) as the male parent (Nicolosi et al., 2000; Froelicher et al., 2011; García-Lor et al., 2013a; Curk et al., 2016).

The Mediterranean Basin is a major area of lemon production, accounting for $48 \%$ of production worldwide (Duportal et al., 2013). Turkey is the most important lemonproducing country in this area (annual production greater than 1,000,000 tons), followed by Spain (900,000 tons) and Italy (500,000 tons) (Martín and González, 2014). Seedless lemons with high organoleptical qualities and resistance to important diseases, such as Mal secco caused by Phoma tracheiphila, are in high demand by consumers and growers (Uzun et al., 2008; Perez-Tornero et al., 2012; Licciardello et al., 2006; Migheli et al., 2009). Several lemon-breeding programs worldwide are focused on meeting this demand (Calabrese et al., 2000; Recupero et al., 2005; Spiegel-Roy et al., 2007; Uzun et al., 2008; Pérez-Tornero et al., 2012), despite the difficulties imposed by the high heterozygosity and low genetic variation of this species (Krueger and Navarro, 2007).

In Citrus, diploidy is the general rule, with a basic chromosome number $\mathrm{x}=9$ (Krug, 1943), although triploid and tetraploid genotypes are present in the citrus germplasm (Lee, 1988). Triploid citrus plants are currently being produced in various breeding programs for the development of new seedless commercial citrus varieties (Starrantino and Recupero, 1981; Ollitrault et al., 2008; Grosser et al., 2010; Navarro et al., 2015). Triploid citrus plants can be recovered from interploid hybridizations, $2 \mathrm{x} x$ 4x and 4x $\mathrm{x}$ 2x (Esen and Soost, 1973b; Cameron and Burnett, 1978; Starrantino and Recupero, 1981; Ollitrault et al., 2008; Grosser and Gmitter, 2011; Aleza et al., 2012a, b; Navarro et al., 2015), or by $2 \mathrm{x} \times 2 \times$ sexual hybridizations as a consequence of unreduced (2n) gamete formation (Esen and Soost, 1971, 1973a; Ollitrault et al., 2008; Aleza et al., 2010b; Cuenca et al., 2015; Navarro et al., 2015). The sexual 2x x 2x hybridization strategy was used by Geraci et al. (1975) and Esen and Soost (1975) to obtain triploid progenies using 'Lisbon' and 'Eureka' lemons as female parents. Viloria and Grosser (2005) and Recupero et al. (2005) recovered progenies of triploid lemon-like hybrids via 2x x 4x sexual hybridizations. Pérez-Tornero et al. (2012) started a lemon-breeding program in 2008 aimed at obtaining triploid hybrids of higher quality than 'Fino' and 'Verna' lemons, the most important lemon varieties in Spain.

The frequency of $2 \mathrm{n}$ female gametes, an intrinsic characteristic of citrus genotypes, can vary from less than 1\% to over 20\% (Esen and Soost, 1971; Ollitrault et al., 2008). For C. limon, $1 \%$ and $5 \%$ of triploid progenies were recovered from $2 \mathrm{x} \times 2 \mathrm{x}$ sexual hybridizations using 'Lisbon' and 'Eureka' lemons as the female parents, respectively (Esen and Soost, 1975; Geraci et al., 1975). Moreover, Pérez-Tornero et al. (2012) obtained $5.8 \%$ to $8.6 \%$ of triploid hybrids from a $2 \times 1 \times 2 \times$ cross between 'Verna' and 'Fino' genotypes. Various meiotic aberrations can result in unreduced gamete formation. First-division restitution (FDR) and second-division restitution (SDR) are the predominant mechanisms of $2 \mathrm{n}$ gamete formation in plants (De Storme and Geelen, 2013). These gametes are produced as a consequence of the failure of the first or second meiotic division, respectively, leading to the formation of restitution nuclei with a 
somatic chromosome number (Mendiburu and Peloquin, 1976; Park et al., 2007). As a result, FDR and SDR have different genetic implications. FDR 2 n gametes contain nonsister chromatids, which in the absence of crossover maintain the parental heterozygosity. When crossing over occurs, the parental heterozygosity restitution (PHR) rates vary from $100 \%$ for loci close to the centromere to $60-70 \%$ for loci far from the centromere, depending on the level of chromosome interference (Cuenca et al., 2011). For SDR, the 2n gametes contain two sister chromatids, which reduces the parental heterozygosity level (Bastiaanssen et al., 1998; Cuenca et al., 2011; De Storme and Geelen, 2013). When crossing over occurs, the PHR rate varies from $0 \%$ for loci close to the centromere to $60-75 \%$ for loci far from the centromere, depending on the level of chromosome interference (Cuenca et al., 2011). SDR is the dominant mechanism involved in the origin of unreduced female gametes in clementines and mandarins (Luro et al., 2004; Cuenca et al., 2011, 2015; Aleza et al., 2016a). Ferrante et al. (2010) reported that FDR is the main mechanism for unreduced female gamete formation in lemon. However, their results were based on the analysis of only a few individuals with few markers and without previous knowledge of centromere location. Other mechanisms leading to unreduced gamete formation have been described, such as pre-meiotic (PRD) and post-meiotic genome doubling (PMD). Although PMD was identified in potato (Bastiaanssen et al., 1998), both mechanisms have only rarely been documented in plants (De Storme and Geelen, 2013). PRD produces 2n gametes equivalent to the meiosis of doubled diploid genotypes. Therefore, PHR depends mainly on the chromosomal preferential pairing rate (Stift et al., 2008), which should vary between $66 \%$ for fully tetrasomic meiosis to $100 \%$ for fully disomic meiosis. Little variation can occur along the chromosome due to double reduction events. In the case of PMD, haploid gametes undergo an extra round of genome duplication, leading to the formation of fully homozygous 2n gametes (Bastiaanssen et al., 1998; Ramanna and Jacobsen, 2003; De Storme and Geelen, 2013; Cuenca et al., 2015). Thus, $100 \%$ homozygosity for all loci is expected among the $2 \mathrm{n}$ gametes (Ramanna and Jacobsen, 2003). SDR can also produce 100\% homozygosity for centromeric markers, but not for telomeric ones (Cuenca et al., 2011). Therefore, in order to distinguish between both mechanisms, Cuenca et al. (2015) genotyped telomeric loci to determine whether diploid gametes fully homozygous for centromeric markers resulted from PMD or SDR. Moreover, Bastiaanssen et al. (1998) identified 2n female gametes of potatoes fully homozygous for RFLP markers. The evidence for recombination between alleles originating from the two ancestors of the parent producing $2 \mathrm{n}$ gametes indicated that these gametes originated from PMD. Molecular marker analyses can be used to estimate the PHR rates for diploid gametes in polyploid progenies and, therefore, to identify the mechanisms underlying unreduced gamete formation (Cuenca et al., 2011). Cuenca et al. (2015) took advantage of known citrus centromere locations (Aleza et al., 2015) to develop a maximum-likelihood method that distinguishes between SDR and FDR mechanisms at both the population and individual levels based on the PHR patterns of unlinked markers located close to the centromeres of different chromosomes.

In this study, we analyzed the frequencies of $2 n$ gamete formation and the meiotic mechanisms leading to $2 \mathrm{n}$ gamete formation in two varieties of lemon, 'Eureka Frost' and 'Fino', through genetic analysis of triploid and tetraploid hybrids recovered from $2 \mathrm{x}$ $\mathrm{x} 2 \mathrm{x}$ and $2 \mathrm{x}$ x $4 \mathrm{x}$ sexual hybridizations. We used the maximum-likelihood method based on centromeric molecular markers in conjunction with a telomeric loci study and analysis of the pattern of PHR variation along LG 1 to identify the mechanisms underlying unreduced gamete formation at the individual and population level. Cross 
over interference was also analysed. We discuss the implications for breeding programs based on sexual polyploidization.

\section{Materials and Methods}

\section{Plant material}

Triploid and tetraploid citrus hybrids were obtained via $2 \mathrm{x} \times 2 \mathrm{x}$ and $2 \mathrm{x} \times 4 \mathrm{x}$ sexual hybridizations using diploid 'Eureka Frost' and 'Fino' lemon genotypes as female parents pollinated with diploid 'Fortune' mandarin $(C$. clementina $\mathrm{x} C$. tangerina) and $C$. ichangensis and tetraploid $C$. macrophylla. Flowers in pre-anthesis were emasculated, pollinated, and enclosed with a cloth bag. A total of 115 'Eureka Frost' lemon flowers were pollinated, including 55 with 'Fortune' mandarin (named EuFor) and 60 with $C$. ichangensis (named EuIch), while 15 'Fino' lemon flowers were pollinated with tetraploid C. macrophylla (named FinMac). The detailed methods used for plant recovery via in vitro embryo rescue and ploidy level analysis via flow cytometry can be found in Aleza et al. (2010a, b; 2012a, b).

\section{Genotyping of progenies using Simple Sequence Repeats (SSR) and Single Nucleotide Polymorphism (SNP) markers}

The male and female parents and 48 hybrids were genotyped using 34 molecular markers (16 Simple Sequence Repeats [SSRs] and 18 Single Nucleotide Polymorphisms [SNPs]) showing heterozygosity for the lemon genotypes and polymorphism with the male parents. These markers are distributed across all LGs of the clementine genetic map (Ollitrault et al., 2012a) (Table 2.1).

Genomic DNA was isolated using a Plant DNeasy kit from Qiagen Inc. (Valencia, CA, USA) following the manufacturer's protocol. PCR amplifications using 16 SSR markers were performed using a Thermocycler rep gradient $S$ (Eppendorf®) in a $10 \mu \mathrm{L}$ final volume containing $0.8 \mathrm{U}$ of Taq DNA polymerase (Fermentas $\left.{ }^{\circledR}\right), 2 \mathrm{ng} / \mathrm{mL}$ citrus DNA, $0.2 \mathrm{mM}$ welled (Sigma ${ }^{\circledR}$ ) dye-labeled forward primer, $0.2 \mathrm{mM}$ non-dye-labeled reverse primer, $0.2 \mathrm{mM}$ of each dNTP, 10× PCR buffer, and $1.5 \mathrm{mM} \mathrm{MgCl}_{2}$. The PCR protocol was as follows: denaturation at $94^{\circ} \mathrm{C}$ for 5 min followed by 40 cycles of $30 \mathrm{~s}$ at $94^{\circ} \mathrm{C}, 1$ min at $50^{\circ} \mathrm{C}$ or $55^{\circ} \mathrm{C}$, and $45 \mathrm{~s}$ at $72^{\circ} \mathrm{C}$; and a final elongation step of $4 \mathrm{~min}$ at $72^{\circ} \mathrm{C}$. Capillary electrophoresis was carried out using a CENTM 8000 Genetic Analysis System (Beckman Coulter Inc.). The PCR products were initially denatured at $90^{\circ} \mathrm{C}$ for $2 \mathrm{~min}$, injected at $2 \mathrm{kV}$ for $30 \mathrm{~s}$, and separated at $6 \mathrm{kV}$ for $35 \mathrm{~min}$. Alleles were sized based on a DNA size standard (400 bp). Genome Lab ${ }^{\mathrm{TM}}$ Gap v.10.0 genetic analysis software was used for data collection. Allele dosage was calculated using the MAC-PR (microsatellite DNA allele counting-peak ratio) method (Esselink et al., 2004), validated in citrus by Cuenca et al. (2011). 
Table 2.1. Information about the molecular markers used in this study, including GenBank accession numbers, genetic distances, noted alleles, and references.

\begin{tabular}{|c|c|c|c|c|c|c|c|c|c|c|c|c|c|c|}
\hline \multirow[b]{2}{*}{ Locus } & \multirow[b]{2}{*}{$\begin{array}{c}\text { Phytozome / Gene } \\
\text { Bank Accesion }\end{array}$} & \multirow[b]{2}{*}{ LG } & \multirow[b]{2}{*}{ GMP (cM) } & \multirow[b]{2}{*}{ DC } & \multicolumn{4}{|c|}{$\frac{\text { Noted alleles }^{1}}{\sigma}$} & \multicolumn{5}{|c|}{ Used to identify the } & \multirow[b]{2}{*}{ Bibliographic reference } \\
\hline & & & & & 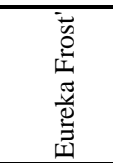 & 竞 & ن & 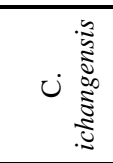 & 志 & 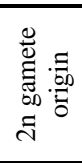 & อิ & 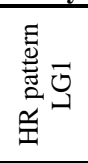 & $\sum_{i=1}$ & \\
\hline CIBE6126 & ET084980 & 1 & 2.69 & 57.97 & $218-220$ & $218-220$ & $218-218$ & $223-230$ & $230-244$ & & & 1 & & Ollitrault et al. (2010) \\
\hline $\mathrm{CiC} 2110-02$ & ET099643 & 1 & 29.61 & 31.05 & A-C & A-C & A-A & A-A & $\mathrm{C}-\mathrm{C}$ & & & 1 & & Ollitrault et al. (2012b) \\
\hline mCrCIR06B05 & AM489744 & 1 & 50.27 & 10.39 & $187-199$ & $187-199$ & $187-187$ & $185-185$ & $187-187$ & & & 1 & & Froelicher et al. (2008) \\
\hline MEST001 & DY262452 & 1 & 70.61 & 9.95 & $176-192$ & $176-192$ & $187-199$ & $190-190$ & $172-172$ & 1 & 1 & 1 & & Luro et al. (2008) \\
\hline CiC5950-02 & ET083949 & 1 & 91.37 & 30.71 & A-G & A-G & A-A & A-A & G-G & & & 1 & & Ollitrault et al. (2012b) \\
\hline MEST431 & DY291553 & 1 & 119.00 & 58.34 & $331-348$ & $331-348$ & $345-348$ & $340-342$ & $331-331$ & & & 1 & & Garcia-Lor et al. (2012a) \\
\hline JK-CAC15 & none & 2 & 43.51 & 13.36 & $160-163$ & $160-163$ & $152-160$ & $160-160$ & $151-163$ & & 1 & 1 & & Kijas et al. (1997) \\
\hline mCrCIR03C08 & FR677576 & 2 & 82.19 & 25.32 & $210-214$ & $210-214$ & $198-214$ & $210-214$ & $226-226$ & & & & 1 & Cuenca et al. (2011) \\
\hline $\mathrm{CiC} 3712-01$ & ET079481 & 2 & 93.92 & 37.05 & $\mathrm{AC}$ & $\mathrm{AC}$ & AA & AA & AA & & & & 1 & Ollitrault et al. (2012b) \\
\hline JK-TAA41 & none & 2 & 131.86 & 74.99 & $145-150$ & $145-150$ & $132-154$ & $147-162$ & $137-147$ & 1 & & & 1 & Kijas et al. (1997) \\
\hline 3P165889 & Ciclev10023360m.g & 3 & 1.00 & 89.59 & $\mathrm{AG}$ & $\mathrm{AG}$ & $\mathrm{AA}$ & AA & $\mathrm{AG}$ & & & & 1 & Curk et al. (2015) \\
\hline 3P11355960 & Ciclev10023509m.g & 3 & 88.50 & 2.09 & $\mathrm{AG}$ & AG & AG & AA & AA & & 1 & & & Curk et al. (2015) \\
\hline CiC1459-02 & ET073328 & 3 & 118.06 & 27.47 & $\mathrm{AC}$ & $\mathrm{AC}$ & $\mathrm{CC}$ & $\mathrm{CC}$ & AA & & & & 1 & Ollitrault et al. (2012b) \\
\hline MEST131 & DY276912 & 3 & 179.33 & 88.74 & $135-147$ & $135-147$ & $147-147$ & $135-141$ & $141-141$ & 1 & & & & Garcia-Lor et al. (2012a) \\
\hline CiC4240-04 & ET106812 & 4 & 7.09 & 9.05 & $\mathrm{AG}$ & $\mathrm{AG}$ & GG & GG & $\mathrm{AG}$ & & 1 & & & Ollitrault et al. (2012b) \\
\hline mCrCIR07D06 & FR677581 & 4 & 16.33 & 0.19 & $164-168$ & $164-168$ & $168-168$ & $166-178$ & $166-168$ & & 1 & & & Cuenca et al. (2011) \\
\hline mCrCIR03G05 & FR677578 & 4 & 75.06 & 58.92 & $226-229$ & $226-229$ & $218-218$ & $218-218$ & $199-228$ & & & & 1 & Cuenca et al. (2011) \\
\hline $5 \mathrm{p} 22687304$ & Ciclev10001185m.g & 5 & 21.00 & 2.12 & $\mathrm{AC}$ & $\mathrm{AC}$ & $\mathrm{AC}$ & AA & $\mathrm{AA}$ & & 1 & & & Curk et al. (2015) \\
\hline CiC5842-02 & ET083106 & 5 & 77.34 & 54.22 & $\mathrm{AC}$ & $\mathrm{AC}$ & $\mathrm{CC}$ & $\mathrm{CC}$ & $\mathrm{AC}$ & & & & 1 & Ollitrault et al. (2012b) \\
\hline $\mathrm{CiC} 4356-06$ & ET107540 & 6 & 6.21 & 0.19 & $\mathrm{CT}$ & $\mathrm{CT}$ & $\mathrm{CT}$ & $\mathrm{CC}$ & $\mathrm{CT}$ & & 1 & & & Ollitrault et al. (2012b) \\
\hline 6p7496245 & Ciclev10013603m.g & 6 & 6.50 & 0.10 & $\mathrm{GC}$ & $\mathrm{GC}$ & $\mathrm{GC}$ & $\mathrm{CC}$ & $\mathrm{CC}$ & & 1 & & & Curk et al. (2015) \\
\hline LapXcF238 & EU719653 & 6 & 11.00 & 4.60 & $\mathrm{GC}$ & $\mathrm{GC}$ & GG & GG & $\mathrm{GC}$ & & 1 & & & Ollitrault et al. (2012b) \\
\hline MEST488 & DY297637 & 6 & 68.48 & 62.08 & $119-133$ & $119-133$ & $119-127$ & $143-153$ & $147-155$ & & & & 1 & Garcia-Lor et al. (2012a) \\
\hline JK-TAA1 & none & 6 & 93.49 & 87.09 & $170-180$ & $170-180$ & $146-162$ & $146-162$ & $160-164$ & 1 & & & & Kijas et al. (1997) \\
\hline mCrCIR03B07 & FR677573 & 7 & 83.39 & 13.04 & $269-273$ & $269-273$ & $273-277$ & $267-282$ & $267-282$ & & 1 & & & Cuenca et al. (2011) \\
\hline $\mathrm{CiC} 3674-02$ & ET079224 & 7 & 23.56 & 72.87 & AG & AG & AA & AA & $\mathrm{AG}$ & & & & 1 & Ollitrault et al. (2012b) \\
\hline $8 \mathrm{P} 18684429$ & Ciclev10028449m.g & 8 & 56.00 & 1.79 & $\mathrm{CT}$ & $\mathrm{CT}$ & CT & $\mathrm{CC}$ & $\mathrm{CC}$ & & 1 & & & Curk et al. (2015) \\
\hline $8 \mathrm{P} 16570424$ & Ciclev10029557m.g & 8 & 50.00 & 4.21 & AG & AG & GG & GG & AA & & 1 & & & Curk et al. (2015) \\
\hline $8 \mathrm{P} 2427684$ & Ciclev10029965m.g & 8 & 20.69 & 33.52 & AT & AT & TT & TT & AA & & & & 1 & Curk et al. (2015) \\
\hline Ci02B07 & AJ567403 & 9 & 0.00 & 52.16 & $164-170$ & $164-170$ & $170-172$ & $162-172$ & $178-182$ & 1 & & & & Froelicher et al. (2008) \\
\hline CiC4876-07 & ET080580 & 9 & 2.69 & 49.47 & AT & AT & TT & TT & AT & & & & 1 & Ollitrault et al. (2012b) \\
\hline 9p4699283 & Ciclev10005777m.g & 9 & 50.00 & 2.16 & $\mathrm{AG}$ & $\mathrm{AG}$ & AG & AA & AA & & 1 & & & Curk et al. (2015) \\
\hline CIBE3966 & ET105040 & 9 & 52.27 & 0.11 & $106-118$ & $106-118$ & $118-\mathrm{N}$ & $106-118$ & $106-118$ & & 1 & & & Ollitrault et al. (2010) \\
\hline Ci07C09 & AJ567410 & 9 & 53.00 & 0.84 & $242-250$ & $242-250$ & $242-252$ & $240-242$ & $242-242$ & & 1 & & & Froelicher et al. (2008) \\
\hline
\end{tabular}

LG: linkage group; GMP: genetic map position; DC: distance to the centromere, PMD: post-meiotic doubling mechanism 
Triploid and tetraploid hybrids were also genotyped with 18 SNP markers using KASPar ${ }^{\mathrm{TM}}$ technology by LGC Genomics (http//www.lgcgenomics.com). The KASPar Genotyping System is a competitive, allele-specific dual Förster Resonance Energy Transfer (FRET)-based assay for SNP genotyping. Primers were directly designed by LGC Genomics Company based on the SNP locus-flanking sequence (approximately 50 nt on each side of the SNP). SNP genotyping was performed using the KASPar technique. A detailed description of specific conditions and reagents can be found in Cuppen (2007). Identification of allele doses in heterozygous triploid and tetraploid hybrids was carried out based on the relative allele signals, as described by Cuenca et al. (2013a) and Aleza et al. (2015).

\section{Identification of the parent producing the unreduced gamete and inference of the unreduced gamete genotype}

For triploid and tetraploid hybrids, the $2 \mathrm{n}$ gamete origin was determined by identifying the parent that passed double genetic information onto the hybrid. Markers with total differentiation between the parents $\left(\mathrm{A}_{1} \mathrm{~A}_{1} \times \mathrm{A}_{2} \mathrm{~A}_{2} \mathrm{~A}_{2} \mathrm{~A}_{2}, \mathrm{~A}_{1} \mathrm{~A}_{2} \times \mathrm{A}_{3} \mathrm{~A}_{3} \mathrm{~A}_{3} \mathrm{~A}_{3}\right.$, and $\mathrm{A}_{1} \mathrm{~A}_{2} \mathrm{x}$ $\mathrm{A}_{3} \mathrm{~A}_{3} \mathrm{~A}_{4} \mathrm{~A}_{4}$ in $2 \mathrm{x} \times 4 \mathrm{x}$ crosses) for tetraploids and $\left(\mathrm{A}_{1} \mathrm{~A}_{1} \times \mathrm{A}_{2} \mathrm{~A}_{2}, \mathrm{~A}_{1} \mathrm{~A}_{2} \times \mathrm{A}_{3} \mathrm{~A}_{3}\right.$, and $\mathrm{A}_{1} \mathrm{~A}_{2} \times \mathrm{A}_{3} \mathrm{~A}_{4}$ in $2 \times \mathrm{x} \times 2 \times$ crosses) for triploids were the best allelic configurations, as described by Aleza et al. (2015) and Cuenca et al. (2015). Indeed, conclusive results can be obtained using only one marker, as was the case for FinMac hybridization using the JK-TAA41 SSR marker. However, for EuFor and EuIch hybridizations, more than one marker had to be analyzed to observe both alleles from the female parent at least once for each hybrid. The SSRs JK-TAA1, JK-TAA41, and MEST131 were used for EuFor hybridization, and JK-TAA1, JK-TAA41, MEST001, and Ci02B07 were used for EuIch.

Once the female origin of the diploid gamete was demonstrated, inference of the allelic configurations of the $2 \mathrm{n}$ gametes from hybrid genotyping was performed as described by Cuenca et al. (2011). In the case of FinMac tetraploid hybridization, for the $\mathrm{A}_{1} \mathrm{~A}_{2} \mathrm{x}$ $\mathrm{A}_{3} \mathrm{~A}_{3} \mathrm{~A}_{3} \mathrm{~A}_{3}$ and $\mathrm{A}_{1} \mathrm{~A}_{2} \times \mathrm{A}_{3} \mathrm{~A}_{3} \mathrm{~A}_{4} \mathrm{~A}_{4}$ allelic configurations, the genotype of the unreduced gamete was deduced directly from observation of both $A_{1}$ and $A_{2}$ alleles in the tetraploid hybrids. However, when the male and female parents shared one allele $\left(\mathrm{A}_{1} \mathrm{~A}_{2}\right.$ $x A_{1} A_{1} A_{1} A_{1}$ and $\left.A_{1} A_{2} \times A_{1} A_{1} A_{3} A_{3}\right)$, for the tetraploid hybrids that inherited the common allele $\left(A_{1}\right)$, inference of the unreduced female gamete structure was carried out based on the estimated allele dosage in the tetraploid hybrid.

In the case of triploid hybrids obtained from EuFor and EuIch hybridizations, for $\mathrm{A}_{1} \mathrm{~A}_{2}$ $x A_{3} A_{3}$ and $A_{1} A_{2} x A_{3} A_{4}$, the genotype of the $2 n$ gamete was deducted directly from the triploid hybrid structure. When the male and female genitors shared one allele $\left(\mathrm{A}_{1} \mathrm{~A}_{2} \mathrm{x}\right.$ $\mathrm{A}_{2} \mathrm{~A}_{2}$ and $\mathrm{A}_{1} \mathrm{~A}_{2} \times \mathrm{A}_{2} \mathrm{~A}_{3}$ ), the $2 \mathrm{n}$ female gamete structure for the triploid hybrids with a common allele from the male genitor was inferred from the estimated allele dosage in the triploid hybrid.

\section{Identification of the mechanism underlying unreduced gamete formation}

For the EuFor and EuIch progenies, nine SSR and SNP molecular markers within 20 $\mathrm{cM}$ of the centromere (Aleza et al., 2015) located in all nine LGs of the clementine genetic map (Ollitrault et al., 2012a) were genotyped to determine the mechanism of $2 \mathrm{n}$ 
gamete formation for each population. The molecular markers used included MEST001, JK-CAC15, 3p11355960, mCrCIR07D06, 5p22687304, 6p7496245, mCrCIR03B07, 8p18684429, and Ci07C09 for EuFor hybridization and MEST001, JK-CAC15, 3p11355960, mCrCIR07D06, 5p22687304, CiC4356-06, mCrCIR03B07, 8p18684429, and 9p4699283 for EuIch hybridization. For FinMac hybridization, seven molecular markers distributed in seven LGs were used, including MEST001, JK-CAC15, CiC4240-04, LapXcF238, mCrCIR03B07, 8P16570424, and CIBE3966.

To distinguish between the SDR and FDR hypotheses, the maximum-likelihood method based on the LOD score test described by Cuenca et al. (2015) was employed. LODs $>2$ were considered to be significant for SDR, those $<-2$ were considered to be significant for FDR, and those between 2 and -2 were considered not to be significant. To compare the SDR hypothesis with the PRD hypothesis using LOD scores, we considered the minimum value of $66 \%$ of PHR as the theoretical value for the PRD hypothesis.

Additionally, a set of six SSR and SNP molecular markers distributed along LG 1 were used to analyze PHR evolution, including SSR markers MEST001, mCrCIR06B05, CIBE6126, and MEST431 and SNP markers CiC5950-02 and CiC2110-02. Moreover, a complementary experiment was performed to differentiate between PMD and SDR mechanisms using 11 telomeric molecular markers in LG 2 to LG 9. These included SSR markers mCrCIR03C08, JK-TAA41, MEST488, and mCrCIR03G05 and SNP markers CiC4876-07, CiC3674-02, CiC5842-02, CiC1459-02, CiC3712-01, 3p165889, and 8p2427684 (Table 2.1).

\section{Interference analysis}

Taking into account the centromere position, three-point linkage mapping was performed to estimate chiasma interference for each chromosome arm of chromosome I. The centromere was used as the first point, and two markers were selected on each arm (MEST001 and MEST431 on one arm and mCrCIR06B05 and CIBE6126 on the other arm). The chromosome interference coefficient (IC) is defined as follows (Griffiths et al., 1996):

$$
\mathrm{IC}=1-\left[\frac{r d}{r_{C M_{1}} \cdot r_{M_{1} M_{2}}}\right]
$$

Where $\mathrm{r}_{\mathrm{CM} 1}$ indicates the observed recombination rate (heterozygous to homozygous and vice versa) between the centromere and locus $1 ; \mathrm{r}_{\mathrm{M} 1 \mathrm{M} 2}$, the observed recombination between locus 1 and 2; and rd, the observed rate of double recombination between the centromere and locus 2 . 


\section{$\underline{\text { Results and Discussion }}$}

\section{Parental origin of recovered plants and frequencies of unreduced gametes}

For sexual hybridizations between 'Eureka Frost' lemon as the female parent and 'Fortune' mandarin and $C$. ichangensis as the male parents, the average fruit set was $45.5 \%$ and $36.7 \%$, respectively (Table 2.2), yielding 250 and 464 seeds, respectively, from both hybridizations. We classified the seeds by size, since, according to Aleza et al. (2010a), seed size is highly correlated to ploidy level. While small seeds are expected to contain triploid embryos, tetraploids are generally observed in normal size seeds. Thus, we selected 45 and 40 small seeds from the EuFor and EuIch hybridizations, respectively, for plant regeneration by embryo rescue.

Table 2.2. Plant regeneration and ploidy level of plants recovered from 'Eureka Frost' $\mathrm{x}$ 'Fortune' mandarin (EuFor), 'Eureka Frost' x C. ichangensis (EuIch) and 'Fino' x $C$. macrophylla (FinMac)

\begin{tabular}{|c|c|c|c|c|c|c|c|c|c|c|c|}
\hline Hybridization & $\begin{array}{l}\text { Pollinated } \\
\text { flowers }\end{array}$ & $\begin{array}{l}\text { Fruits } \\
\text { set }\end{array}$ & $\begin{array}{c}\text { Total } \\
\text { number } \\
\text { of } \\
\text { seeds }\end{array}$ & $\begin{array}{l}\text { Normal } \\
\text { seeds }\end{array}$ & $\begin{array}{l}\text { Undeveloped } \\
\text { seeds }\end{array}$ & $\begin{array}{l}\text { Small } \\
\text { seeds }\end{array}$ & $\begin{array}{l}\text { Cultured } \\
\text { embryos }\end{array}$ & $\begin{array}{l}\text { Recovered } \\
\text { plants }\end{array}$ & $\begin{array}{l}\text { Diploid } \\
\text { plants }\end{array}$ & $\begin{array}{l}\text { Triploid } \\
\text { plants }\end{array}$ & $\begin{array}{l}\text { Tetraploid } \\
\text { plants }\end{array}$ \\
\hline EuFor & 55 & 25 & 464 & 419 & 0 & 45 & 54 & 53 & 32 & 21 & 0 \\
\hline EuIch & 60 & 22 & 250 & 210 & 0 & 40 & 40 & 35 & 21 & 14 & 0 \\
\hline FinMac & 15 & 8 & 156 & 36 & 154 & 36 & 36 & 36 & 0 & 23 & 13 \\
\hline
\end{tabular}

From the 45 small seeds obtained in the EuFor hybridization, 54 embryos were cultured in vitro, with an average of 1.2 embryos per seed, indicating a low rate of polyembryony in 'Eureka Frost' lemon. Of the 53 plantlets recovered, 32 were diploid and 21 triploid. All 40 small seeds recovered from the EuIch hybridization contained only a single embryo. Of the 35 plants regenerated, 21 were diploid and 14 were triploid. For the FinMac 2x x 4x sexual hybridization, the average fruit set was $53.3 \%$, and 36 normal seeds were obtained according to the size classification of Aleza et al. (2012b). Of the 36 plants recovered, 23 were triploid and 13 were tetraploid (Table 2.2).

To determine which parent passed double genetic information onto the hybrids, we genotyped triploid hybrids recovered from the $2 \mathrm{x} \times 2 \mathrm{x}$ hybridizations using markers that displayed total allelic differentiation between 'Eureka Frost' lemon and the male parents, 'Fortune' mandarin and $C$. ichangensis (Figure 2.1): SSR markers JK-TAA1, JK-TAA41, and MEST131 for the EuFor hybridization and SSR markers JK-TAA1, JK-TAA41, MEST001, and Ci02B07 for the EuIch hybridization. Genetic analysis enabled us to unequivocally identify the hybrid origins of all triploid plants, except for one plant from the EuFor sexual hybridization and four from the EuIch sexual hybridization, which were rejected since they could have originated from autopollination of the female parents. Genetic analysis showed that 'Eureka Frost' lemon produced the $2 \mathrm{n}$ gametes for all triploid hybrids, as shown in Figure 2.1.

For the tetraploid hybrids, the JK-TAA41 SSR marker displayed total allelic differentiation between 'Fino' lemon and tetraploid C. macrophylla, allowing us to conclude that all plants were hybrids and that 'Fino' lemon produced the $2 \mathrm{n}$ gametes (Figure 2.1). Analysis of the genetic origins of the 23 triploid plants recovered from this 
$2 \mathrm{x} \times 4 \mathrm{x}$ hybridization showed that, as expected, they were obtained from the union of a normal reduced haploid female gamete and a normal reduced diploid pollen gamete, as previously observed in other citrus species (Aleza et al., 2012a).
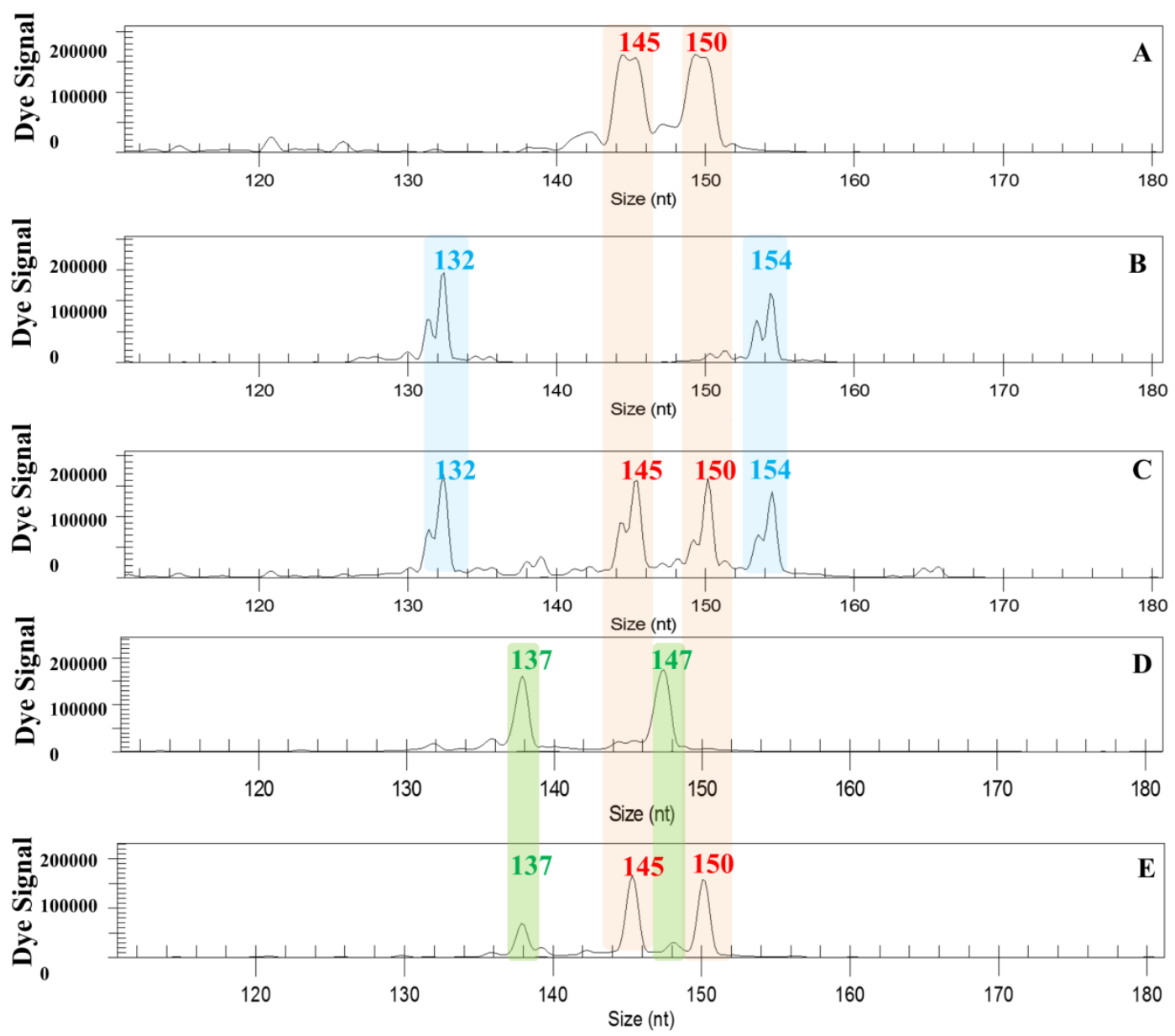

Figure 2.1. Electropherograms of a triploid and a tetraploid hybrid recovered from EuIch and FinMac hybridizations using SSR marker JK-TAA 41. A. 'Fino' and 'Eureka Frost' lemons displayed the same allelic configuration for this marker; B. $C$. macrophylla; C. tetraploid hybrid with four different alleles from 'Fino' $\mathrm{x} 4 \mathrm{x} C$. macrophylla hybridization. D. C. ichangensis; E. Triploid hybrids with two alleles from the female parent 'Eureka Frost' lemon and one from the male parent $C$. ichangensis. nt: nucleotides.

Lemon hybrids were obtained from $2 \mathrm{n}$ gametes at a frequency of $4.9 \%$ for 'Eureka Frost' and 8.3\% for 'Fino'. Geraci et al. (1975) reported frequencies of 1\% and 5\% for triploid hybrids assumed to be obtained through unreduced gametes of 'Lisbon' and 'Eureka' lemons, respectively. Pérez-Tornero et al. (2012) obtained triploid hybrids at a frequency of $5.8 \%$ to $8.6 \%$ in hybridizations between diploid plants of 'Verna' as the female parent and 'Fino' as the male parent. In mandarins, greater differences between genotypes have been observed, ranging from less than $1 \%$ for clementines to over $22 \%$ for 'Sukega' and 'Ortanique' tangor (Ollitrault et al., 2008; Aleza et al., 2010b; Wakana et al., 1982; Esen and Soost, 1971; Xie et al., 2014). 
The frequency of $2 \mathrm{n}$ gametes was shown to be genotype-dependent in citrus and in other herbaceous and woody plants such as Brassica, potato, and peach (Dermen, 1938; Mok and Peloquin, 1975; Ollitrault et al., 2008; Aleza et al., 2010b; Mason et al., 2011; Younis et al., 2014). This hypothesis is supported by the genetic improvement of unreduced gamete rates for Trifolium (frequencies increased from $0.04 \%$ to $47 \%$ ) and Medicago sativa (from $9 \%$ to $78 \%$ ) in only three generations of recurrent selection (Gallais, 2003).

In the current study, we observed a rate of $4.9 \% 2 \mathrm{n}$ gametes in the $2 \mathrm{x} \times 2 \mathrm{x}$ hybridizations (EuFor and EuIch), whereas, in the $2 \mathrm{x} \times$ 4x hybridization (FinMac), the percentage was higher $(8.3 \%)$. These differences might be due to a genotypic effect of the parents, but are more likely due to the modification of the embryo/endosperm ploidy level ratio in interploid hybridizations. Esen and Soost (1971) reported that, in diploid plants, when an unreduced gamete is pollinated with normal reduced pollen, the embryo/endosperm ploidy level ratio (3/5) is less favorable for embryo development than that for normal diploid embryos (2/3), whereas the pollination of a $2 \mathrm{n}$ female gamete with diploid pollen in $2 \mathrm{x} \times 4 \mathrm{x}$ sexual hybridizations provides the correct embryo/endosperm ploidy level ratio $(4 / 6=2 / 3)$, leading to normal seed development. Therefore, $2 \mathrm{x} \times \mathrm{x}$ hybridization appears to be a more favorable situation for revealing unreduced gametes via the development of tetraploid embryos in normal seeds.

\section{Mechanism of unreduced gamete formation}

To determine the mechanism leading to unreduced gamete formation, we used nine unlinked molecular markers localized in the nine LGs for EuFor and EuIch and seven such markers in seven different LGs for FinMac to perform a LOD score test for SDR/FDR and SDR/PRD probability ratios for all genotypes analyzed (Tables 2.3, 2.4, 2.5). The analysis of six markers covering LG 1 and additional telomeric loci allowed us to distinguish between SDR and PMD when the inferred gametes were totally homozygous for the centromeric loci.

\section{LOD score analysis}

For the EuFor hybridization, 20 triploid hybrids were genotyped using nine centromeric loci found in all LGs. Ten of the inferred $2 \mathrm{n}$ gametes were totally homozygous for these markers. However, all displayed at least one heterozygous marker when six markers covering LG 1 were analyzed, allowing the PMD hypothesis to be rejected for all inferred $2 \mathrm{n}$ gametes. For the SDR/FDR hypothesis test at the individual level, 19 inferred $2 \mathrm{n}$ gametes displayed LOD values $>2$ (ranging from 12.05 to 15.22 ; Table 2.3). For the same 19 gametes, the LOD values for SDR/PRD were also >2. Therefore, these 19 plants were considered to have originated from SDR. One plant obtained negative LODs of -4.52 and -6.86 for the SDR/FDR and SDR/PRD hypotheses, respectively, suggesting that this plant is of FDR or PRD origin. At the population level, the LOD values were 267.82 and 57.03 for the SDR/FDR and SDR/PRD hypotheses, respectively, revealing a high rate of SDR. 
Table 2.3. Heterozygous and homozygous profiles for 2 n gametes from EuFor hybridization analyzed using SSR and SNP markers close to the centromere of each LG and the LOD score test for SDR/FDR and SDR/PRD probability ratio.

\begin{tabular}{|c|c|c|c|c|c|c|c|c|c|c|c|}
\hline MARKER & MEST001 & JK-CAC15 & 3p 11355960 & mCrCIR07D06 & $5 p 22687304$ & 6p 7496245 & mCrCIR03B07 & 8p 18684429 & Ci07C09 & \multirow{5}{*}{$\begin{array}{l}\text { LOD } \\
\text { (SDR/ } \\
\text { FDR) }\end{array}$} & \multirow{4}{*}{$\begin{array}{c}\text { LOD } \\
\text { (SDR/P } \\
\text { RD) }\end{array}$} \\
\hline LG & 1 & 2 & 3 & 4 & 5 & 6 & 7 & 8 & 9 & & \\
\hline Centromere Position (cM) & 0.607 & 0.569 & 0.906 & 0.161 & 0.231 & 0.064 & 0.964 & 0.542 & 0.522 & & \\
\hline Marker Position (cM) & 0.706 & 0.435 & 0.885 & 0.163 & 0.210 & 0.065 & 0.834 & 0.560 & 0.530 & & \\
\hline Distance to the centromere (cM) & 0.099 & 0.134 & 0.021 & 0.002 & 0.021 & 0.001 & 0.130 & 0.018 & 0.008 & & \\
\hline Genotypes analyzed & $2 \mathrm{n}$ gamete genetic configuration & & & & & & & & & & \\
\hline EuFor 1 & $\mathrm{HO}$ & $\mathrm{HO}$ & $\mathrm{HO}$ & $\mathrm{HO}$ & $\mathrm{HO}$ & $\mathrm{HO}$ & $\mathrm{HO}$ & $\mathrm{HO}$ & $\mathrm{HO}$ & 15.22 & 3.87 \\
\hline EuFor 2 & $\mathrm{HO}$ & $\mathrm{HO}$ & $\mathrm{HO}$ & $\mathrm{HO}$ & $\mathrm{HO}$ & $\mathrm{HO}$ & $\mathrm{HO}$ & $\mathrm{HO}$ & $\mathrm{HO}$ & 15.22 & 3.87 \\
\hline EuFor 3 & $\mathrm{HO}$ & $\mathrm{HO}$ & $\mathrm{HO}$ & $\mathrm{HO}$ & $\mathrm{HO}$ & $\mathrm{HO}$ & $\mathrm{HO}$ & $\mathrm{HO}$ & $\mathrm{HO}$ & 15.22 & 3.87 \\
\hline EuFor 4 & $\mathrm{HO}$ & $\mathrm{HO}$ & $\mathrm{HO}$ & $\mathrm{HO}$ & $\mathrm{HO}$ & $\mathrm{HO}$ & $\mathrm{HO}$ & $\mathrm{HO}$ & $\mathrm{HO}$ & 15.22 & 3.87 \\
\hline EuFor 5 & $\mathrm{HO}$ & $\mathrm{HO}$ & $\mathrm{HO}$ & $\mathrm{HO}$ & $\mathrm{HO}$ & $\mathrm{HO}$ & $\mathrm{HO}$ & $\mathrm{HE}$ & $\mathrm{HO}$ & 12.05 & 2.14 \\
\hline EuFor 6 & $\mathrm{HE}$ & $\mathrm{HO}$ & $\mathrm{HO}$ & $\mathrm{HO}$ & $\mathrm{HO}$ & $\mathrm{HO}$ & $\mathrm{HO}$ & $\mathrm{HO}$ & $\mathrm{HO}$ & 13.66 & 2.97 \\
\hline EuFor 7 & $\mathrm{HO}$ & $\mathrm{HO}$ & $\mathrm{HO}$ & $\mathrm{HO}$ & $\mathrm{HO}$ & $\mathrm{HO}$ & $\mathrm{HO}$ & $\mathrm{HO}$ & $\mathrm{HO}$ & 15.22 & 3.87 \\
\hline EuFor 8 & HE & $\mathrm{HO}$ & $\mathrm{HO}$ & $\mathrm{HO}$ & $\mathrm{HO}$ & $\mathrm{HO}$ & $\mathrm{HO}$ & $\mathrm{HO}$ & $\mathrm{HO}$ & 13.66 & 2.97 \\
\hline EuFor 9 & $\mathrm{HO}$ & $\mathrm{HO}$ & $\mathrm{HE}$ & $\mathrm{HO}$ & $\mathrm{HO}$ & $\mathrm{HO}$ & $\mathrm{HO}$ & $\mathrm{HO}$ & $\mathrm{HO}$ & 12.19 & 2.21 \\
\hline EuFor 10 & $\mathrm{HO}$ & $\mathrm{HO}$ & $\mathrm{HO}$ & $\mathrm{HO}$ & $\mathrm{HO}$ & $\mathrm{HO}$ & $\mathrm{HO}$ & $\mathrm{HO}$ & $\mathrm{HO}$ & 15.22 & 3.87 \\
\hline EuFor 11 & $\mathrm{HO}$ & $\mathrm{HE}$ & $\mathrm{HO}$ & $\mathrm{HO}$ & $\mathrm{HO}$ & $\mathrm{HO}$ & $\mathrm{HO}$ & $\mathrm{HO}$ & $\mathrm{HO}$ & 13.97 & 3.13 \\
\hline EuFor 12 & $\mathrm{HO}$ & $\mathrm{HE}$ & $\mathrm{HO}$ & $\mathrm{HO}$ & $\mathrm{HO}$ & $\mathrm{HO}$ & $\mathrm{HO}$ & $\mathrm{HO}$ & $\mathrm{HO}$ & 13.97 & 3.13 \\
\hline EuFor 13 & $\mathrm{HO}$ & $\mathrm{HO}$ & $\mathrm{HO}$ & $\mathrm{HO}$ & $\mathrm{HO}$ & $\mathrm{HO}$ & $\mathrm{HO}$ & $\mathrm{HO}$ & $\mathrm{HO}$ & 15.22 & 3.87 \\
\hline EuFor 14 & $\mathrm{HO}$ & $\mathrm{HO}$ & $\mathrm{HO}$ & $\mathrm{HO}$ & $\mathrm{HO}$ & $\mathrm{HO}$ & $\mathrm{HO}$ & $\mathrm{HO}$ & $\mathrm{HO}$ & 15.22 & 3.87 \\
\hline EuFor 15 & $\mathrm{HO}$ & $\mathrm{HO}$ & $\mathrm{HO}$ & $\mathrm{HO}$ & $\mathrm{HO}$ & $\mathrm{HO}$ & $\mathrm{HO}$ & $\mathrm{HO}$ & $\mathrm{HO}$ & 15.22 & 3.87 \\
\hline EuFor 16 & $\mathrm{HO}$ & $\mathrm{HE}$ & $\mathrm{HO}$ & $\mathrm{HO}$ & $\mathrm{HO}$ & $\mathrm{HO}$ & $\mathrm{HO}$ & $\mathrm{HO}$ & $\mathrm{HO}$ & 13.97 & 3.13 \\
\hline EuFor 17 & $\mathrm{HO}$ & $\mathrm{HE}$ & $\mathrm{HO}$ & $\mathrm{HO}$ & $\mathrm{HO}$ & $\mathrm{HO}$ & $\mathrm{HE}$ & $\mathrm{HO}$ & HO & 12.70 & 2.38 \\
\hline EuFor 18 & $\mathrm{HO}$ & $\mathrm{HE}$ & $\mathrm{HO}$ & $\mathrm{HO}$ & $\mathrm{HO}$ & $\mathrm{HO}$ & $\mathrm{HO}$ & $\mathrm{HO}$ & $\mathrm{HO}$ & 13.97 & 3.13 \\
\hline EuFor 19 & $\mathrm{HO}$ & $\mathrm{HO}$ & $\mathrm{HO}$ & $\mathrm{HO}$ & $\mathrm{HO}$ & $\mathrm{HO}$ & $\mathrm{HO}$ & $\mathrm{HO}$ & $\mathrm{HO}$ & 15.22 & 3.87 \\
\hline EuFor 20 & $\mathrm{HE}$ & $\mathrm{HO}$ & $\mathrm{HE}$ & $\mathrm{HE}$ & $\mathrm{HE}$ & $\mathrm{HO}$ & $\mathrm{HO}$ & $\mathrm{HE}$ & $\mathrm{HE}$ & -4.52 & -6.86 \\
\hline $\begin{array}{c}\text { Population LODs } \\
\end{array}$ & 267.82 & 57.03 & & & & & & & & & \\
\hline
\end{tabular}

LODs $>2$ are significant for SDR. LOD $<-2$ are significant for FDR or PRD. LODs between 2 and -2 are not significant.

HE: Heterozygous; HO: homozygous 
For EuIch hybridization, 10 triploid hybrids were genotyped with nine centromeric markers located on all LGs. Two inferred $2 n$ gametes were totally homozygous for these markers, but at least one heterozygous locus was observed for each 2 n gamete in LG 1 , discarding the PMD hypothesis. At the individual level, eight plants displayed LOD values $>2$ for SDR/FDR (from 8.69 to 14.53), rejecting the FDR hypothesis (Table 2.4). Among these, seven displayed a LOD $>2$ for SDR/PRD (ranging from 2.13 to 3.86) and were considered to have arisen from SDR. The LOD value for the remaining $2 \mathrm{n}$ gamete was 0.55 , suggesting that this $2 \mathrm{n}$ gamete had arisen from SDR rather than PRD, but, since this value is below our threshold, this result is not conclusive. Two plants produced negative LOD values (<-2) in both the SDR/FDR and SDR/PRD tests, suggesting that they originated by FDR or PRD. The population LODs were 80.21 and 2.77 , respectively, for SDR/FDR and SDR/PRD, confirming the predominance of the SDR mechanism.

For FinMac, 13 tetraploid hybrids were genotyped with seven centromeric markers (LGs 1, 2, 4, 6, 7, 8, and 9). Six inferred 2n gametes were totally homozygous for these markers (Table 2.5). Among these, two unreduced gametes (from FinMac 12 and FinMac 13) remained totally homozygous after analyzing six markers covering LG 1 and were subjected to additional analysis to distinguish between the SDR and PMD hypothesis. The $112 \mathrm{n}$ gametes with at least one heterozygous locus produced LOD values $>2$ for SDR/FDR, rejecting the FDR hypothesis. Among these, four displayed LOD values of 2.81 for the SDR/PRD test and were therefore considered to have arisen from SDR. The seven remaining $2 \mathrm{n}$ gametes displayed positive values ranging from 0.52 to 1.91 . These gametes had a higher probability of arising from SDR than from PRD, but this result is not conclusive because the values are below our threshold. The population LOD values were 78.84 and 19.81 for SDR/FDR and SDR/PRD, respectively, again confirming the prevalence of SDR. The seven $2 \mathrm{n}$ gametes with inconclusive individual LODs display a population LOD of 43.12 and 8.56 for $\mathrm{SDR} / \mathrm{FDR}$ and SDR/PRD, respectively. It is therefore highly probable that they also arose from SDR. 
Table 2.4. Heterozygous and homozygous profiles for $2 \mathrm{n}$ gametes from EuIch hybridization analyzed using SSR and SNP markers close to the centromere of each LG and the LOD score test for SDR/FDR and SDR/PRD probability ratio.

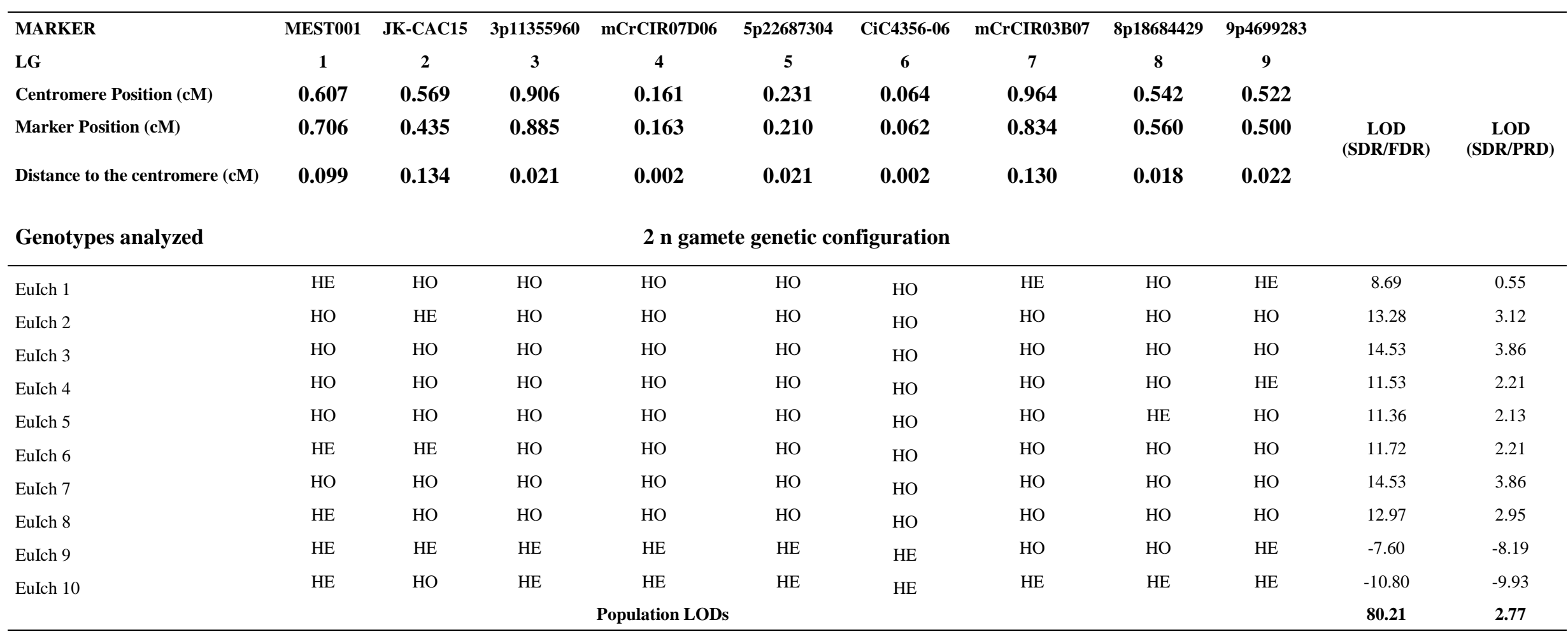

LODs $>2$ are significant for SDR. LOD < -2 are significant for FDR or PRD. LODs between 2 and -2 are not significant.

HE: Heterozygous; HO: Homozygous 
Table 2.5. Heterozygous and homozygous profiles for $2 \mathrm{n}$ gametes from FinMac hybridization analyzed using SSR and SNP markers close to the centromeres of seven LGs and the LOD score test for SDR/FDR and SDR/PRD probability ratio.

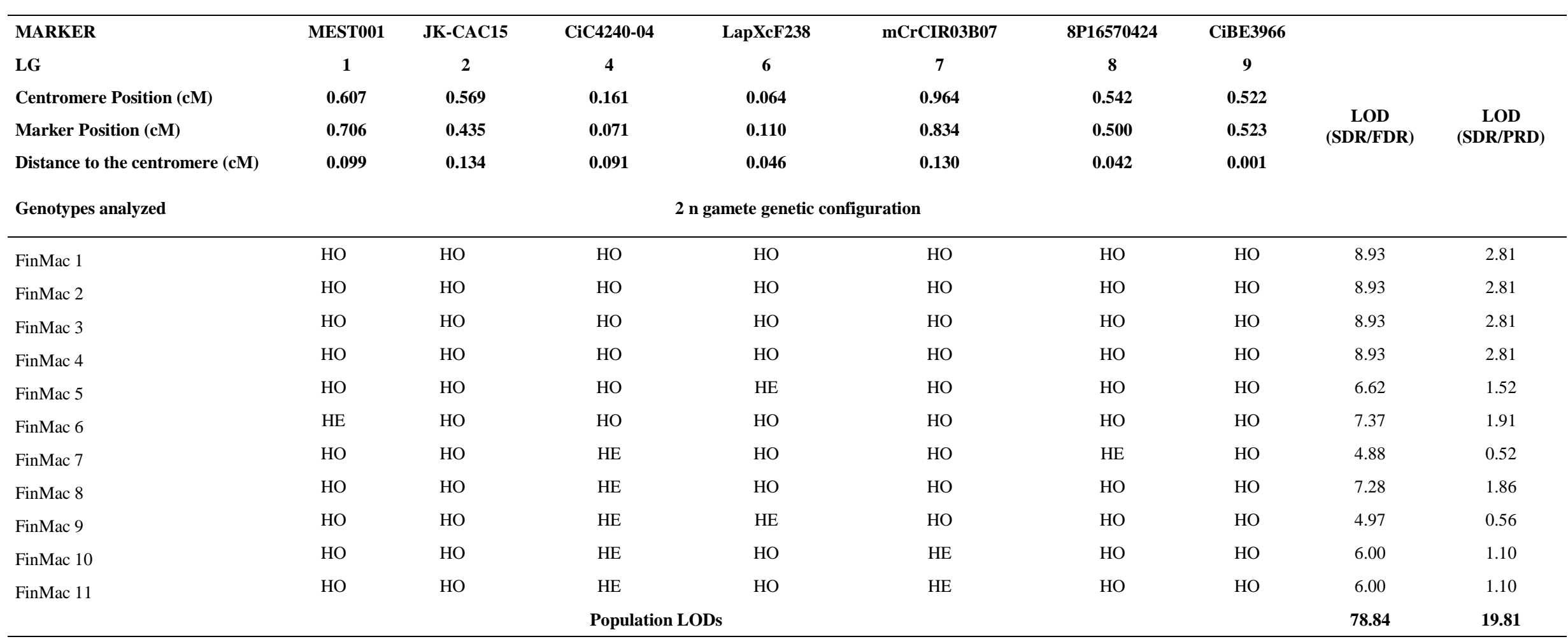

LODs $>2$ are significant for SDR. LOD $<-2$ are significant for FDR or PRD. LODs between 2 and -2 are not significant.

HE: Heterozygous; HO: Homozygous 


\section{Pattern of heterozygosity restitution along LG 1 for $2 n$ gametes with an identified $S D R$ origin and undetermined SDR/PRD origin}

To validate (at the population level) the finding that 38 2n gametes were derived by SDR (as determined by individual LOD analysis) and to distinguish between SDR and PRD for the eight gametes with inconclusive individual LODs, we compared the PHR patterns of the two sets of gametes in LG 1. For this analysis, we used four SSR markers (CIBE6126, mCrCIR06B05, MEST001, and MEST431) and two SNP markers (CiC2110-02 and CiC5950-02) (Figure 2.2) mapped in LG 1 (Figures 2.3 and 2.4).

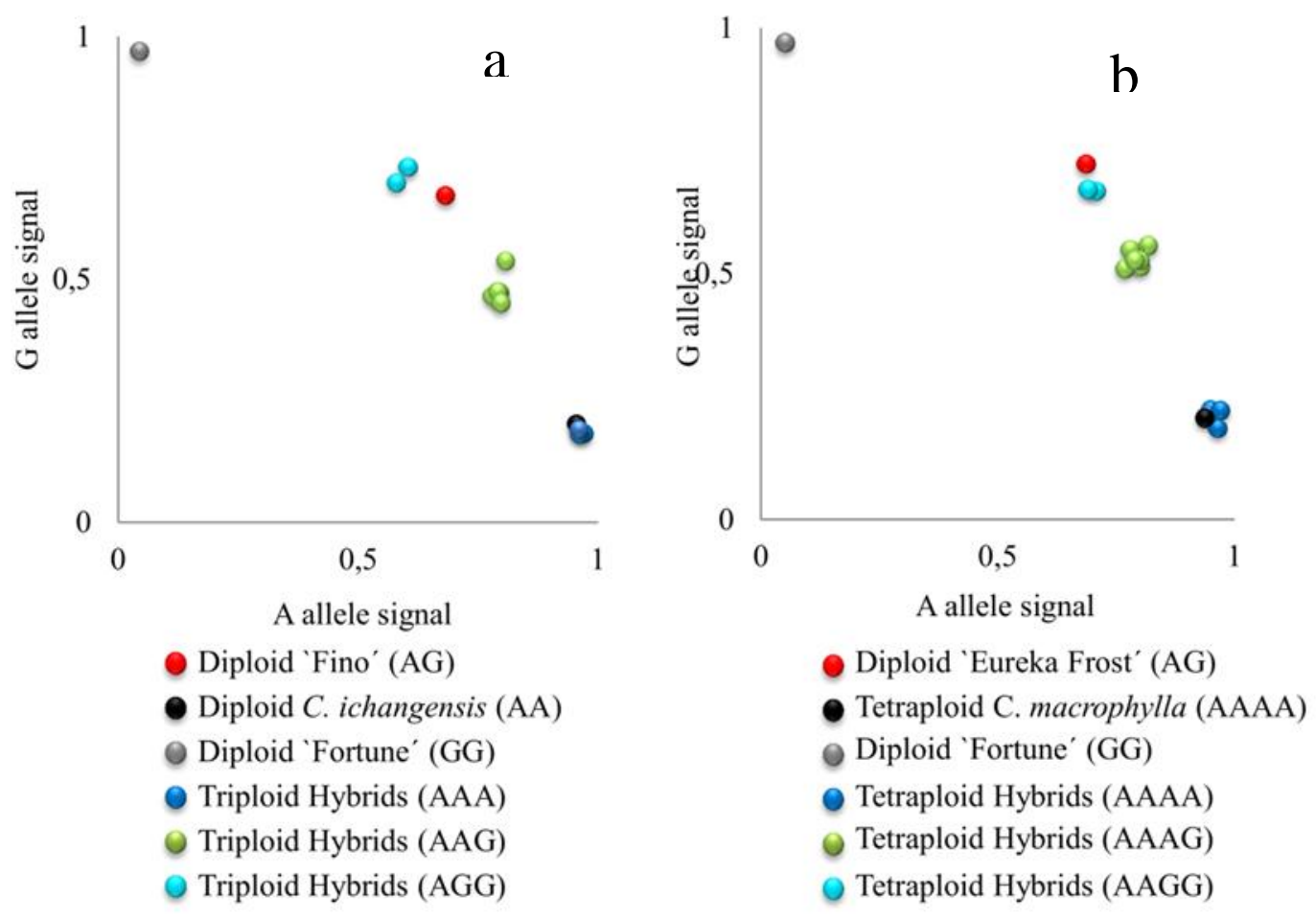

Figure 2.2. Plot of A, G allele signals of SNP marker CiC5950-02 representing triploid (a) and tetraploid (b) hybrids from EuIch and FinMac sexual hybridizations. Letters indicate the allelic configuration for each hybrid.

For the conclusive SDR gamete set, the PHR values in LG 1 (Figure 2.3) decreased from $67 \%$ for the telomeric marker CIBE6126 to $3 \%$ for the centromeric marker mCrCIR06B05 and progressively increased to $77 \%$ when moving towards the other telomeric marker, MEST431. The average PHR value was 42\%. For the eight inconclusive $2 \mathrm{n}$ gametes, the same PHR pattern was observed: the lowest value was obtained for the centromeric marker mCrCIR06B05 (0\%) and the highest for the telomeric markers (63\% for CiC2110-02 in one telomere and 75\% for MEST431 in the other). The average PHR for these eight gametes was $46 \%$ (Figure 2.3). These PHR patterns totally fit the profile for SDR. The average PHR value over the two sets of $2 \mathrm{n}$ gametes was $43 \%$. Various studies have indicated that the global restitution of heterozygosity is expected to be near $80 \%$ for FDR and $40 \%$ for SDR, assuming a random distribution of heterozygous loci along the chromosomes (Peloquin, 1983; Hutten et al., 1994; Carputo et al., 2003). Both the patterns along LG 1 and the average PHR values comply with the SDR hypothesis. Therefore, we conclude that the eight $2 \mathrm{n}$ 
gametes of indeterminate origin identified from the individual LOD (SDR/PRD) analysis also originated from SDR. Under this conclusion, the PHR pattern in LG 1 are very similar for 'Eureka Frost' and 'Fino' lemon SDR 2n gamete populations (Figure 2.4).

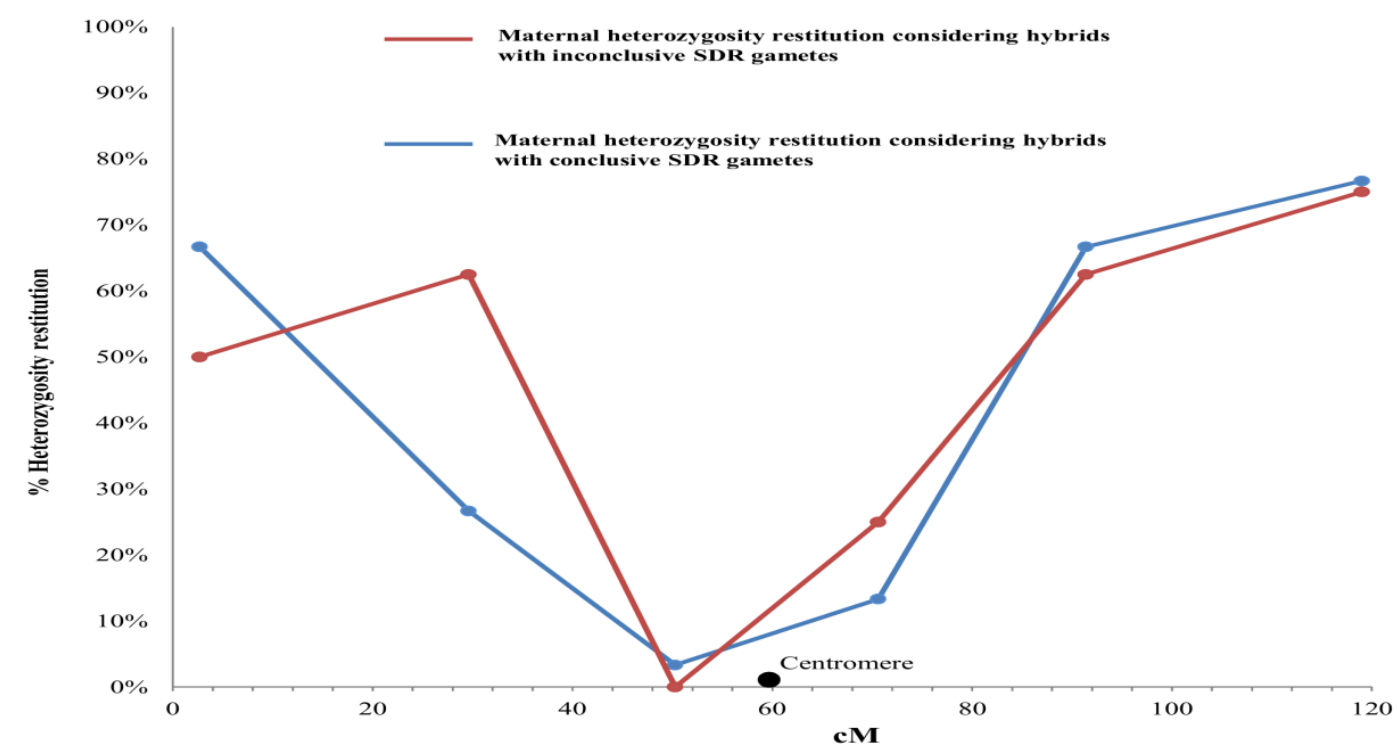

Figure 2.3. Evolution of maternal heterozygosity restitution values of the analyzed SSR and SNP markers in LG 1 considering the significance of the obtained LOD values for each hybrid from 'Eureka Frost' and 'Fino' lemons with conclusive and inconclusive SDR 2n gametes. Black dot indicates the centromere position on the reference clementine genetic map (Ollitrault et al., 2012a).

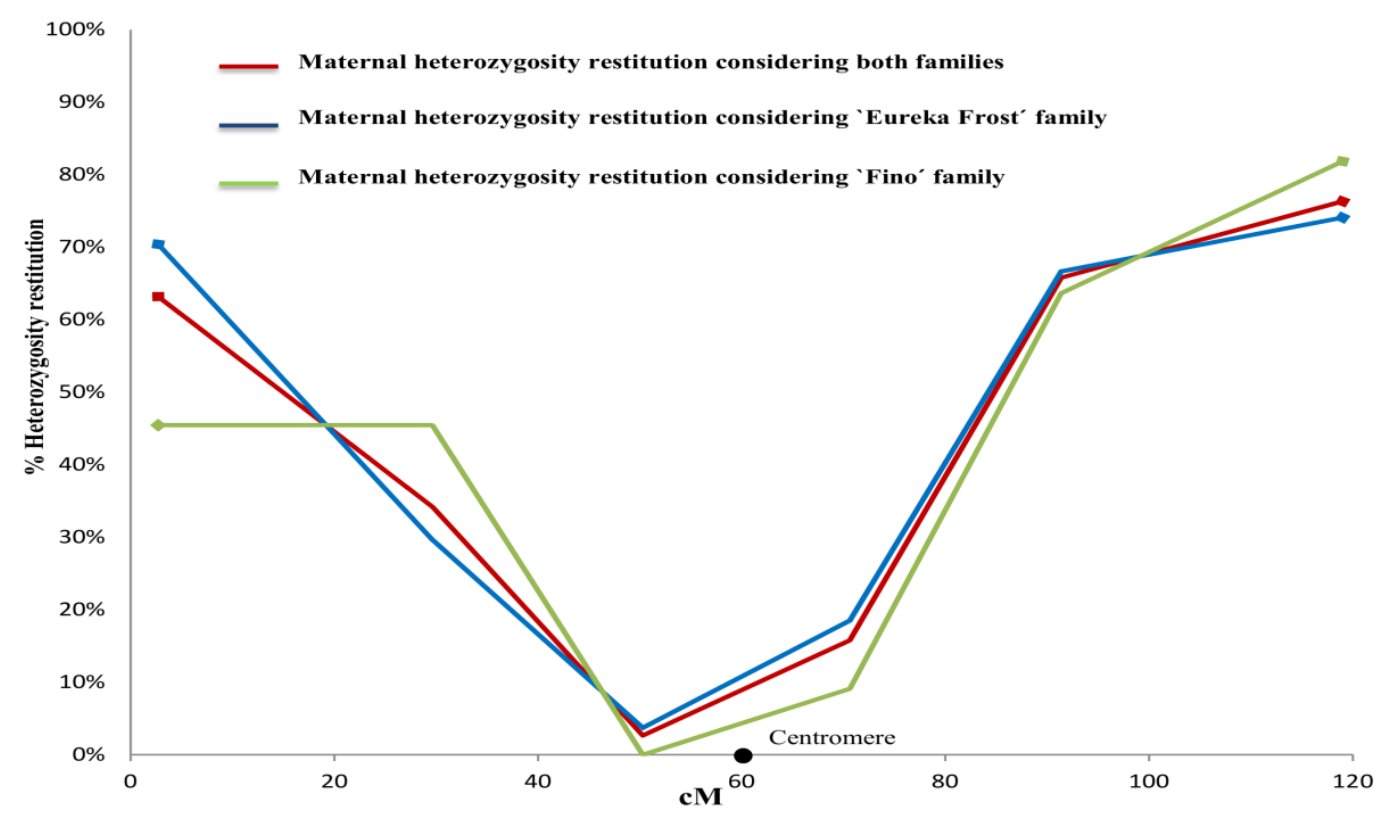

Figure 2.4. Evolution of maternal heterozygosity restitution values of the analyzed SSR and SNP markers in LG 1 considering both populations, 'Eureka Frost' and 'Fino' lemon SDR 2n gametes. Black dots indicate the centromere position on the reference clementine genetic map (Ollitrault et al., 2012a). 


\section{Distinction between SDR and PMD for fully homozygous $2 n$ gametes}

We performed additional analyses of the two inferred 2n gametes (FinMac 12 and FinMac 13 tetraploid plants) fully homozygous for the seven centromeric markers and the six markers of LG 1 . Fully homozygous 2 female gametes for centromeric loci can originate through SDR or PMD, with different consequences for the genetic structures of 2 n gametes. Bastiaanssen et al. (1998) defined two conditions that are necessary to conclude that PMD rather than SDR has occurred, i.e., 100\% homozygosity for all genotyped loci and the occurrence of recombination between homozygous alleles in the same LG. Therefore, we genotyped FinMac 12 and FinMAc 13 using 11 telomeric loci found in different LGs to provide genetic evidence for a particular PMD mechanism. The average distance from these markers to their corresponding centromere is $53.22 \mathrm{cM}$ (ranging from 25.32 to $89.59 \mathrm{cM}$ ). Both plants were homozygous for all molecular markers analyzed. Furthermore, $C$. limon is a direct hybrid between two genetically distant genotypes, C. aurantium and C. medica (Nicolosi et al., 2000; Curk et al., 2016), and the specific origins of the homozygous alleles can easily be distinguished. We found that some homozygous markers of the same LG were inherited from the $C$. aurantium ancestor and the others from $C$. medica. For example, multilocus analyses of the homozygous alleles in LG 1 (Figure 2.5) revealed interspecific recombination in the two plants with alternation of homozygosity originated from $C$. aurantium and $C$. medica. Consequently, according to Bastiaanssen et al. (1998), the observation of $100 \%$ homozygosity and recombination between $C$. aurantium and $C$. medica along the same LG provides evidence discarding the SDR mechanism and leads us to conclude that these two 2n gametes originated through PMD.

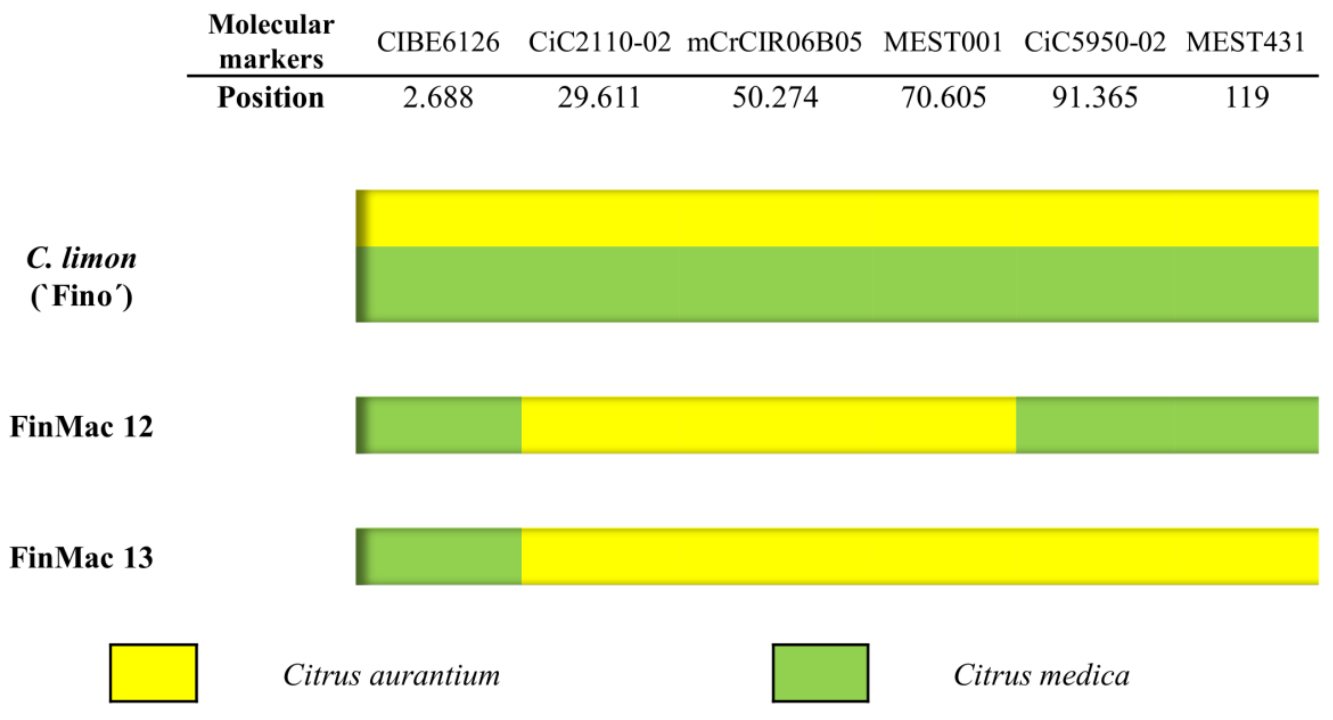

Figure 2.5. Multilocus configuration of the two fully homozygous plants recovered from FinMac hybridization with six molecular markers located on LG 1. Yellow indicates the presence of homozygous alleles inherited from $C$. aurantium, and green indicates those from $C$. medica. 


\section{Synthesis of different approaches}

On the whole, we conclude that $38(88 \%)$ of the $2 n$ gametes analyzed had arisen from SDR, three (7\%) from FDR or PRD, and two (5\%) from PMD. At the population level, SDR appears to be by far the most common mechanism for $2 \mathrm{n}$ ovule formation in both C. limon genotypes, 'Eureka Frost' and 'Fino'. Luro et al. (2004), Aleza et al. (2015) and Cuenca et al. (2015) also found that SDR was the predominant mechanism leading to $2 \mathrm{n}$ megagametophyte production in mandarins. Among the 19 mandarins investigated, the authors concluded that only $1.1 \%$ and $2.9 \%$ of plants were recovered from FDR in the 'Ellendale' and 'Fortune' genotypes, respectively. The coexistence of SDR and FDR has been observed in unreduced pollen (Rouiss et al., 2017a), but with FDR representing the main mechanism. In addition, FDR was the main mechanism for 2n female gamete production in 'Femminello' lemon (Ferrante et al., 2010). These results could be questionable because the authors used only a few molecular markers and lacked previous information about centromere location and the relative distances between the markers and the centromeres. With the recent location of centromeres in the citrus genetic map (Aleza et al., 2015; Ollitrault et al., 2012a), it appears that the markers used by Ferrante et al. (2010), JK-TAA1, JK-TAA15, JK-TAA41, and NBGT03, are mostly telomeric, and therefore the high PHR values obtained in their study can fit both SDR or FDR mechanisms.

At the methodological level, we demonstrated the power of using two complementary approaches, namely, analysis of the PHR pattern in one LG with the maximumlikelihood method proposed by Cuenca et al. (2015). Considering only centromeric loci, different PMD mechanisms can lead to the same homozygous patterns. Therefore, analyzing the heterozygosity restitution pattern along LGs at the individual level is a useful approach for distinguishing between SDR and PMD, since, under this mechanism, the heterozygosity restitution value is zero for all markers in all LGs. After LOD analysis at the individual level, this method is used to analyze PHR patterns at the population level to distinguish between SDR and PRD when individual LODs are under the threshold required to obtain conclusive results. When enough individuals are analyzed, this technique should also be utilized to distinguish between FDR and PRD. With FDR 2n gametes, heterozygosity restitution varies from $100 \%$ in centromeric loci to close to $66 \%$ in telomeric areas under the non-interference model (Cuenca et al., 2011), whereas, with PRD, heterozygosity restitution is expected to be very similar along the entire chromosome.

\section{Crossovers and interference analysis}

Crossover interference ensures the appropriate distribution of crossovers along the chromosome, since one crossover reduces the likelihood of other crossovers occurring nearby (Youds et al., 2010). The analysis of crossover rates (Table 2.6) for both arms of chromosome I revealed the presence of up to four crossovers on one arm and three on the other arm. In addition, three complementary crossovers (double crossing over involving four chromatids) were observed as a result of phase-changing between two homozygous markers. Similarly, Cuenca et al. (2011) and Aleza et al. (2015) detected up to four crossovers on one arm and complementary crossovers in 'Fortune' mandarin and $C$. clementina. We estimated the IC for each chromosome arm, finding partial interference in both arms (IC $=0.27$ and 0.44 ). Such variation in interference values between both arms has also been observed in other citrus species, ranging from 0.82 to 
0.48 for 'Fina' clementine on LG 1 (Aleza et al., 2015) and 0.73 to 0.53 for 'Fortune' mandarin on LG 2 (Cuenca et al., 2011). Variation in the level of interference between different parts of the genome has also been observed in Arabidopsis (Drouaud et al., 2007), humans (Lian et al., 2008), and mice (Broman et al., 2002).

Table 2.6. Number of observed crossover events on each arm of chromosome I based on analysis of 27 genotypes recovered from 'Eureka Frost' lemon pollinated with $C$. ichangensis and 'Fortune' mandarin using six molecular markers. Numbers between brackets indicate the number of complementary crossovers.

\begin{tabular}{cccccccc}
\hline & & \multicolumn{7}{c}{ Arm 1 } & & \\
Number of crossovers & & $\mathbf{0}$ & $\mathbf{1}$ & $\mathbf{2}$ & $\mathbf{3}$ & $\mathbf{4}$ & \\
\hline & $\mathbf{0}$ & 2 & 2 & 1 & 0 & 0 & $\mathbf{1 3 \%}$ \\
$\mathbf{1}$ & 7 & 17 & $3(2)$ & 0 & $1(1)$ & $\mathbf{7 4 \%}$ \\
& $\mathbf{2}$ & 1 & 3 & 0 & 0 & 0 & $\mathbf{1 1 \%}$ \\
& $\mathbf{3}$ & 0 & 1 & 0 & 0 & 0 & $\mathbf{3 \%}$ \\
& & $\mathbf{2 6 \%}$ & $\mathbf{6 1 \%}$ & $\mathbf{1 1 \%}$ & $\mathbf{0 \%}$ & $\mathbf{3 \%}$ & \\
\hline
\end{tabular}

\section{Implications of sexual polyploidization for breeding triploid lemon-like plants}

Sexual polyploidization via $2 \mathrm{n}$ gametes and interploid sexual hybridizations using tetraploid parents (doubled diploids) are the main strategies used to produce triploid citrus hybrids (Ollitrault et al., 2008; Aleza et al., 2010b; 2012a, b; 2016a; Navarro et $a l ., 2015)$. These different strategies and the different meiotic behaviors result in different genetic structures in the diploid gametes and, consequently, the resulting triploid progenies. The three hybrids obtained via FDR or PRD $2 \mathrm{n}$ gametes have a higher rate of heterozygosity than hybrids obtained via SDR. By contrast, the two plants obtained by PMD transmit 0\% PHR (Bastiaanssen et al., 1998). Therefore, such a mechanism (PMD) generally promotes inbreeding in the hybrid progenies (Tai, 1986; Gallais, 2003). However, these lines constitute interesting parentals to be used as test lines in inheritance studies (Bastiaanssen et al., 1998).

In addition, the mechanism that generates the $2 \mathrm{n}$ gametes affects the breeding efficiency for a character in relation to the genetic distance to the centromeres of the major genes controlling this character. For instance, Cuenca et al. $(2013 \mathrm{~b} ; 2016)$ found that Alternaria brown-spot fungal disease is a recessive trait controlled by a single locus located $10.5 \mathrm{cM}$ from the centromere of chromosome III. Therefore, in crosses between a heterozygous parent producing diploid gametes and a resistant genotype, PMD is the most favorable mechanisms (50\% of resistant hybrids), followed by SDR (40\%). Under FDR, only $5 \%$ of the hybrids will be resistant. For diploid gametes produced by the DD genotype or resulting from PDR, the rates of resistant hybrids should vary from $16 \%$ (tetrasomic segregation) to $0 \%$ (disomic segregation) according to the preferential pairing behavior.

The aim of some lemon-breeding programs is to produce new lemon-like types of fruit, which essentially involves $2 \mathrm{x} \times 4 \mathrm{x}$ crosses using diploid lemons as female parents and more or less complex hybrids as tetraploid parents (Viloria and Grosser, 2005; Recupero et al., 2005). This approach is used in an attempt to solve some of the problems caused by the low genetic variation of $C$. limon, although relatively few 
tetraploids are available. This approach has allowed for the selection and protection of the triploid Lemox, a hybrid between a diploid female complex hybrid, and tetraploid lemon (Recupero et al., 2005). Lemox produces quality fruits resembling lemons with high tolerance to Mal secco. The $2 \mathrm{n}$ lemon gametes will be very useful for producing new lemon-like seedless citrus types via $2 \mathrm{x} \times 2 \mathrm{x}$ hybridizations, thereby dramatically increasing the gene pool of genotypes that could be used as parents. Furthermore, the production of $2 \mathrm{n}$ gametes has been investigated in a small number of lemon genotypes. Evaluating the many existing lemon genotypes may result in the detection of specific genotypes that produce higher rates of $2 \mathrm{n}$ gametes and (eventually) genotypes with different ratios of FDR and SDR $2 n$ gametes, which will increase the efficiency of breeding programs. 


\section{Conclusion}

Genetic analysis with SSR and SNP markers revealed that two genotypes of C. limon, 'Eureka Frost' and 'Fino', produced 2n female gametes. The frequencies of $2 \mathrm{n}$ gametes were $4.9 \%$ and $8.3 \%$ for 'Eureka Frost' and 'Fino' lemons, respectively. The use of complementary methods, including individual LOD analysis from centromeric loci, telomeric loci genotyping, and the analysis of PHR patterns along a linkage group, allowed us to distinguish among the different mechanisms of $2 \mathrm{n}$ gamete formation. We detected three meiotic mechanisms in lemon, with $88 \%$ of $2 \mathrm{n}$ female gametes arising from SDR, 7\% from FDR or PRD, and 5\% from PMD. To our knowledge, this is the first report of the production of a large number of lemon progenies from $2 \mathrm{n}$ gametes and the identification of a new mechanism, PMD, that has never been observed in citrus and has rarely been described in other herbaceous or woody species. From the breeding point of view, the production of SDR $2 \mathrm{n}$ gametes would allow progenies with polymorphic genetic structures to be recovered, increasing the likelihood of obtaining new phenotypes by creating an increasing number of novel multilocus allelic combinations. The coexistence of different mechanisms for $2 \mathrm{n}$ gamete formation broadens the diversity of lemon $2 \mathrm{n}$ gametes and, therefore, their potential for breeding. 


\section{CHAPTER III}

Doubled diploid 'Mexican' lime display preferential disomic segregation compatible with an interploid crosses origin of $C$. latifolia and $C$. aurantifolia triploid limes.

Houssem Rouiss, Frédéric Bakry, Yann Froelicher, José Cuenca, Luis Navarro, Pablo Aleza and Patrick Ollitrault

Annals of Botany. Submitted 



\section{Abstract}

Triploid limes have an important worldwide fruit production, but it is based in a very narrow genetic basis. The 'Tahiti' lime type $(C$. latifolia) is predominant, while the 'Tanepao' type (C. aurantifolia) is less produced. Both types resulted from natural interspecific hybridization involving a diploid gamete of $C$. aurantifolia 'Mexican' lime type (a direct interspecific $C$. micrantha x $C$. medica hybrid). Doubled diploid (DD) 'Mexican' lime spontaneously occurs in seedlings. In a first step to implement a reconstruction breeding program of limes, based on phylogenomic data, we analysed the meiotic mechanisms of a DD 'Mexican' lime, the interspecific recombination and the resulting diploid gamete structures to evaluate the possibility that 'Tahiti' and 'Tanepao' varieties derived from interploid hybridization.

A population of 85 tetraploid hybrids was established by pollination of a DD clementine by a DD 'Mexican' lime and used to infer the genotypes of 'Mexican'lime diploid gametes. Meiotic behaviour was studied combining segregation analysis of 35 SSRs and SNPs markers and cytogenetic studies. It was completed by a pollen viability evaluation. Genetic mapping allowed to evaluate the interspecific recombination rates and to compare them to diploid and tetraploid clementine ones.

Pollen viability of the DD 'Mexican' lime (64\%) was much higher than the diploid one. In average, $65 \%$ of the chromosomes were in bivalent configuration and $31.4 \%$ in tetravalent ones. Parental heterozygosity restitution varied between $83 \%$ and $99 \%$. Disomic inheritance with high preferential pairing values was deduced for three LGs. Intermediate inheritance with disomic tendency was found for five LGs and intermediate model was observed for one LG. The average effective interspecific recombination rate was $1.2 \mathrm{cM} / \mathrm{Mb}$, three times lower than in diploid and tetraploid clementines.

The DD 'Mexican' lime had a predominantly disomic segregation producing interspecific diploid gamete structures with high $C$. medica / $C$. micrantha heterozygosity compatible with the phylogenomic structures of triploids $C$. latifolia and C. aurantifolia varieties. This disomic tendency limits the effective interspecific recombination and the diversity of the diploid gamete population. Interploid reconstruction breeding, using doubled diploid lime as one parent is a promising approach for the diversification of triploid limes.

\section{Keywords}

Citrus, DD 'Mexican' lime, C. medica / C. micrantha, Diploid gamete, Markers and Cytogenetic studies, Disomic tendency, Triploid limes. 


\section{$\underline{\text { Introduction }}$}

Limes and lemons are two closely related horticultural groups cultivated under all Mediterranean, sub-tropical and inter-tropical climates with around 15 million tons (Mt) produced worldwide (FAO, 2014). After expanding up to 2007, the lemon market is currently stagnating while the consumption of limes has increased dramatically since the 1980s (Duportal et al., 2013). Interestingly the triploid 'Tahiti' lime is one of the less susceptible citrus varieties for the main threats of citrus production in tropical and subtropical areas, the Huanglongbing disease (HLB) caused by the phloem limited bacteria Candidatus Liberibacter spp. However, the lime production is based on a very narrow genetic basis including a few diploid and triploid cultivars and varietal diversification is needed to promote sustainable lime production. At triploid level the seedless 'Tahiti' lime type is predominantly produced for the export market. The other major triploid variety, the 'Tanepao' lime type, produces seedy fruits and has only limited local areas of production.

The cultivated lime varieties are based on complex interspecific genomic structures as most cultivated citrus. Citrus, is a large genus that includes several major cultivated species. It is believed to be native to Southeast Asia (Webber et al., 1967), and its cultivation as a fruit crops occurred at least 4,000 years ago (Legge, 1865). Molecular markers and genomic studies identified four taxa, C. reticulata, C. maxima, C. medica and $C$. micrantha as the ancestors of all cultivated Citrus species (Nicolosi et al., 2000; Barkley et al., 2006; Ollitrault et al., 2012a; Garcia-Lor et al., 2013b; Curk et al., 2016). The differentiation between these ancestral taxa occurred through allopatric evolution and then the so called secondary species ( $C$. sinensis -sweet oranges-, $C$. aurantium -sour oranges-, $C$. paradisi -grapefruits-, $C$. limon - lemons-) and particularly the limes $(C$. aurantifolia and C. Latifolia) were the result of reticulate evolution with a limited number of interspecific meiosis due to facultative apomixis (nucellar polyembryony).

While many citrus horticultural groups result only from $C$. reticulata and $C$. maxima gene pools at diploid level (Nicolosi et al., 2000; Barkley et al., 2006; Ollitrault et al., 2012a; Garcia-Lor et al., 2013b), the genomic structure of limes appeared more complex. Indeed, it involves the four ancestral taxa (Curk et al., 2016). Moreover lime is the only Citrus horticultural group that include triploid and tetraploid natural germplasm in addition to diploid one. Based on codominant markers various nuclear analysis revealed that diploid 'Mexican' lime $C$. aurantifolia results from a direct natural hybridization between $C$. micrantha as female parent and $C$. medica as male parent (Nicolosi et al., 2000; Ollitrault et al., 2012a; Garcia-Lor et al., 2013b; Curk et al., 2016). The tetraploid 'Giant Key' lime, also classified as C. aurantifolia by Tanaka (1961) was selected in a seedling of the diploid 'Key' lime ('Mexican' lime type) in Florida (US Horticultural Research Laboratory, Orlando) by HC Barrett (Curk et al., 2016) .

Recently, Curk et al. (2016) demonstrated the contribution of the four ancestral taxa to the $C$. latifolia triploid varieties ('Tahiti' lime type) genome and proposed that it resulted from the fertilization of a haploid ovule of $C$. limon by a diploid gamete of $C$. aurantifolia. Lemon is itself a complex genome issued from the hybridization of a citron $(C$. medica) and sour orange (a $C$. maxima x $C$. reticulata direct hybrid). The 
same authors proposed that the $C$. aurantifolia triploid varieties ('Tanepao' lime like), with only $C$. medica and $C$. micrantha contribution, probably resulted from an interspecific backcross of a diploid ovule of $C$. aurantifolia (C. micrantha x C. medica) fertilized by $C$. medica. The actual phenotypic diversity around the 'Tahiti' and 'Tanepao' lime types results from asexual variations (mutations or somaclonal variations).

Polyploidisation is a major mechanism of angiosperm evolution (Soltis and Soltis, 1993; Wendel and Doyle, 2005) and many authors consider that most polyploids arise from unreduced (2n) gametes (Bretagnolle and Thompson, 1995; Ramsey and Schemske, 1998, 2002). Diploidy is the general rule in Citrus with a basic chromosome number of nine (X=9) (Krug 1943) and an estimated genome size of $\sim 367 \mathrm{Mb}$ (Terol et $a l ., 2008)$. Only a few triploid and tetraploid genotypes have been found in the citrus germplasm (Longley, 1925; Lee, 1988). Despite this scarcity of polyploid germplasm, it appeared that polyploidisation events are relatively frequent in citrus seedling. Doubled diploids (DD) plants were observed early in seedling of diploid apomictic genotypes (Lapin, 1937; Russo and Torissi, 1951; Cameron and Frost, 1968) and their frequency depends on genotypes and environment (Aleza et al., 2011). They arise from spontaneous duplication of chromosomes in nucellar cells (Cameron and Frost, 1968; Aleza et al., 2011). The 'Giant Key' lime originated from this mechanism (Curk et al., 2016). Unreduced female and male gametes have also been described in citrus (Esen and Soost, 1971; Ollitrault et al., 2008; Cuenca et al., 2015; Rouiss et al., 2017a) and they can lead to the creation of triploid and tetraploid hybrids. Various mechanisms can produce $2 \mathrm{n}$ gametes in citrus. Second division restitution (SDR) is predominant for $2 \mathrm{n}$ megagametophytes (Esen et al., 1979; Cuenca et al., 2011, 2015; Aleza et al., 2015) while first meiotic restitution (FDR) was described as the major mechanism for the production of $2 \mathrm{n}$ pollen in a clementine $\mathrm{x}$ sweet orange hybrid (Rouiss et al., 2017a). Today there is no evidence on the polyploidisation mechanisms (interploid hybridization or $2 \mathrm{n}$ gametes) that produced triploid $C$. latifolia and $C$. aurantifolia limes.

The genetic structure of diploid gamete populations and particularly the parental heterozygosity restitution (PHR) is driven by their origin. In case of $2 \mathrm{n}$ gametes PHR is a function of the genetic distance to the centromere (Cuenca et al., 2015). In centromeric area PHR is respectively null and total for SDR and FDR respectively, increasing and decreasing with the genetic distance to centromere. For diploid gametes produced by tetraploid plants there are two extreme models, disomic in allotetraploids and tetrasomic in autotetraploids (Stebbins, 1947; Stift et al., 2008; Sybenga, 2012). In allotetraploids, resulting from the merger of two specie's genomes, there are two sets of homologous chromosomes and during meiosis, each chromosome pairs only with its homologous (Sybenga, 2012), and only bivalents are formed (Stebbins, 1947). It results in a disomic inheritance with $100 \%$ of the interspecific heterozygosity transmitted by each gamete (Stift et al., 2008). In autotetraploids, the presence of four homologous chromosomes instead of two, results in equal opportunities to pair at meiosis leading to multivalent formation and tetrasomic inheritance (Jackson and Jackson, 1996; Sybenga, 1996). For doubled diploids, it leads, hypothetically, to $66 \%$ of restitution of the heterozygosity of the diploid that originated the tetraploid (Sanford et al., 1983; Aleza et al., 2016a). Allo and autotetraploids (with disomic and tetrasomic inheritance, respectively) are the extremes of a range. In cases where parents are divergent but have retained enough homology to prevent exclusive preferential pairing, inheritance patterns 
intermediate 'segmental patter' between di and tetrasomic can be expected (Stebbins, 1947; Sybenga, 1996; Stift et al., 2008; Jeridi et al., 2012). Many polyploid taxa display a combination of autopolyploid and allopolyploid pairing behavior (Allendorf and Danzmann 1997; Fjellstrom, et al., 2001; Jackson and Jackson 1996) and several studies presented inheritance patterns intermediate among disomic and tetrasomic (Danzmann and Bogart 1983; Hickok 1978; Marsden et al., 1987; Stift et al., 2008). Stift et al. (2008) developed a likelihood-based approach to evaluate whether disomic, intermediate or tetrasomic inheritances best fitted the segregation of genetic markers and to estimate preferential pairing and double reduction (DR) rates. DR can occur for tetravalents and increases the homozygosity of diploid gametes (Stift et al., 2008; Ronfort et al., 1998; Sybenga, 1995; Aleza et al., 2016a). This method was simplified for doubled-diploids by Aleza et al. (2016a).

Large structural rearrangements (inversions, translocations and deletions), sequences divergence but also genetic control (Jenczewski et al., 2003; Griffiths et al., 2006; Qi et al., 2007 Cifuentes et al. , 2010) and meiosis mutation (such asynapsis or desynapsis) can affect chromosome pairing. Inversion and asynapsis, were described in diploid 'Mexican' lime (Iwamasa et al., 1962; Iwamasa and Nito, 1988) resulting in partial sterility.

In the present work we analyzed the preferential chromosome pairing and inheritance of the interspecific (C. medica / C. micrantha) doubled diploid 'Mexican' lime. It was performed by combining a meiotic cytogenetic study and the analysis of single nucleotide polymorphism (SNP) and simple sequence repeat (SSR) markers segregations. The interspecific recombination and interspecific structures of diploid 'Mexican' lime gametes where then analyzed from the genetic markers data and their compatibility with $C$. aurantifolia and $C$. latifolia triploid lime phylogenomic structure was evaluated. The implications for lime breeding programs are discussed. 


\section{Materials and methods}

\section{Plant materials}

Sexual hybridization between doubled-diploid 'Clemenules' clementine (C. clementina Hort. Ex Tan.) as female parent and doubled-diploid 'Mexican' lime as male parent (Cl4x $\mathrm{x}$ ML4x hybridization) was performed in order to obtain tetraploid hybrids (named ClemMex) to study the segregation model of the doubled-diploid 'Mexican' lime. Doubled-diploid 'Clemenules' clementine was recovered by shoot-tip grafting in vitro and colchicine treatment (Aleza et al., 2009b) whereas tetraploid 'Mexican' lime was identified by flow cytometry in seedlings of diploid 'Mexican' lime and proved to be a doubled-diploid by molecular marker analysis (Aleza et al., 2011). The hybrids were recovered from normal seeds since the pollination of a tetraploid plant with diploid pollen provides the correct embryo/endosperm ploidy level ratio $(4 / 6=2 / 3)$, leading to normal seed development. The ploidy level was verified by flow cytometry as described in Aleza et al. (2010a). Eighty five tetraploid hybrids were obtained.

\section{Pollen viability}

Pollen viability was estimated using aceto-carmine colorimetric tests (Stanley and Linskens, 1947). The stain was added on pollen grains and observed under photonic microscope (Leica DM LB). The pollen viability was scored according to staining level; pollen with bold red colour are viable and colourless are unviable. The percentage of pollen viability was determined as the ratio of the number of viable grains to the total grain number.

\section{Meiotic chromosome preparation}

Fifty one pollen mother cells (PMC) of different anthers were observed and analysed for this work. Basic cytogenetic protocols that have been described for meiotic chromosomes pairing for the genus Musa (Shepherd, 1999) were used. Anthers at the appropriate stage of meiosis were selected by aceto-carmine test preparation of two opposite anthers of each flower harvested from the IVIA Citrus Germplasm Bank of pathogen-free plants (Navarro et al., 2002). They were fixed in a mixture of absolute ethanol, chloroform and acetic acid $(6,3,1)$ for 24 hours. Later they were transferred to $70 \%$ alcohol for storage. The next steps of the protocol were done directly in the slides. The anthers were dissected and stained in a drop of $1 \%$ carmine in $45 \%$ acetic acid. A cover glass was placed, and the slides were warmed to well short of boiling point. The anthers were lightly pressed under the cover glass. Finally the cover glass edges were sealed with nail varnish to avoid drying out of the smear.

\section{Genotyping of progenies using Simple Sequence Repeat (SSR) and Single Nucleotide Polymorphism (SNP) markers}

Genomic DNA of the hybrids and their parents was isolated using the Plant DNAeasy kit from Qiagen Inc. (Valencia, CA, USA), following the manufacturer's protocol. For SSRs, PCR amplifications were performed using a Thermocycle rep gradient $S$ (Eppendorf®) in $10 \mu \mathrm{L}$ final volume containing $0.8 \mathrm{U}$ of Taq DNA polymerase (Fermentas ${ }^{\circledR}$ ), $2 \mathrm{ng} / \mathrm{mL}$ of citrus DNA, $0.2 \mathrm{mM}$ of wellRED (Sigma®) dye-labelled forward primer, $0.2 \mathrm{mM}$ of non dye-labelled reverse primer, $0.2 \mathrm{mM}$ of each dNTP, 
10X PCR buffer and $1.5 \mathrm{mM} \mathrm{MgCl} 2$. The PCR protocol was as follows, denaturation at $94^{\circ} \mathrm{C}$ for $5 \mathrm{~min}$ followed by 40 repeats of $30 \mathrm{~s}$ at $94^{\circ} \mathrm{C}, 1 \mathrm{~min}$ at $50^{\circ} \mathrm{C}$ or $55^{\circ} \mathrm{C}, 45 \mathrm{~s}$ at $72^{\circ} \mathrm{C}$; and a final elongation step of $4 \mathrm{~min}$ at $72^{\circ} \mathrm{C}$. Capillary electrophoresis was carried out using a CEQ ${ }^{\mathrm{TM}} 8000$ Genetic Analysis System (Beckman Coulter Inc.). PCR products were initially denatured at $90^{\circ} \mathrm{C}$ for $2 \mathrm{~min}$, injected at $2 \mathrm{kV}$ for $30 \mathrm{~s}$ and subsequently separated at $6 \mathrm{kV}$ for $35 \mathrm{~min}$. Alleles were sized, based on a DNA size standard (400 bp). The GenomeLab ${ }^{\mathrm{TM}} \mathrm{GeXP}$ v.10.0 genetic analysis software was used for data collection. Allele dosage was calculated using the MAC-PR (microsatellite DNA allele counting-peak ratio) method (Esselink et al., 2004), validated in citrus by Cuenca et al. (2011).

Progenies were also genotyped with SNP markers using KASPar technology. The KASPar ${ }^{\mathrm{TM}}$ Genotyping System is a competitive, allele-specific dual Förster Resonance Energy Transfer (FRET)-based assay for SNP genotyping. Primers were directly designed by LGC Genomics Company based on the SNP locus flanking sequence (approximately $50 \mathrm{nt}$ on each side of the SNP). SNP genotyping was performed using the KASPar technique. Detailed explanation on specific conditions and reagents can be found in Cuppen (2007). Identification of allele doses in heterozygous tetraploid hybrids has been carried out from the relative allele signals as described by Cuenca $e t$ al. (2013).

\section{Control of the hybrid origin of tetraploid plants and inference of the diploid gamete genotype}

Confirmation of hybrids origin was performed using two SSRs (mCrCIR07F11 and MEST001) with total differentiation between the parents $\left(\mathrm{A}_{1} \mathrm{~A}_{2} \times \mathrm{A}_{3} \mathrm{~A}_{4}\right)$.

To study the genetic structure of the diploid gametes produced from the doublesddiploid 'Mexican' lime, the male and female parents and 85 hybrids were genotyped using a total of 35 molecular markers (27 SSRs and 8 SNPs) heterozygote for the 'Mexican' lime and polymorphic with 'Clemenules' clementine (Table 3.1). They are distributed across all LGs of the clementine genetic map (Ollitrault et al., 2012b) with a minimum of three molecular markers in LG07 and a maximum of five molecular markers in LG06 and LG09. Distances of the markers to the centromere were estimated from the clementine genetic map (Ollitrault et al., 2012b) and the estimated centromere genetic mapping (Aleza et al., 2015). In case that the markers were not in the clementine genetic map, their position was inferred from their physical position and local correlations between physical and genetic positions. The marker closer to a centromere was 6P7496245 at $0.10 \mathrm{cM}$ from the centromere of LG06 and the furthest was MEST131 at $88.74 \mathrm{cM}$ from the centromere of LG03. In total, 18 markers are considered as centromeric markers (15 SSR and $3 \mathrm{SNP}$ ), the rest are either telomeric or intermediate markers. In all LGs, at least one centromeric marker (less than $20 \mathrm{cM}$ from the centromere) and one telomeric marker have been used. For 'Mexican' lime the allele inherited from $C$. medica and $C$. micrantha ancestors are respectively in first and second positions in table 3.1 . 
Table 3.1. Molecular markers used to study the genetic structure of the diploid gametes produced from the tetraploid 'Mexican' lime, with their gene bank accesion, genetic position, noted alleles and bibliographic reference

\begin{tabular}{|c|c|c|c|c|c|c|c|}
\hline \multirow[b]{2}{*}{ Locus } & \multirow[b]{2}{*}{ Gene Bank Accesion } & \multirow[b]{2}{*}{ LG } & \multirow{2}{*}{$\begin{array}{c}\text { Genetic } \\
\text { position } \\
\text { (cM) }\end{array}$} & \multirow{2}{*}{$\begin{array}{l}\text { Distance to } \\
\text { centromere }\end{array}$} & \multicolumn{2}{|c|}{ Alleles ${ }^{1}$} & \multirow[b]{2}{*}{ Bibliographic reference } \\
\hline & & & & & Clementine & $\underset{2}{\text { Mexican' lime }}$ & \\
\hline 1P199494 & Ciclev10010680m. & 1 & 1.00 & 59.66 & $\mathrm{C}-\mathrm{C}$ & T-C & Curk et al. (2015) \\
\hline CIBE5720 & ET082224 & 1 & 58.45 & 2.21 & $325-337$ & $320-308$ & Ollitrault et al. (2010) \\
\hline MEST001 & DY262452 & 1 & 70.61 & 9.95 & $170-174$ & $186-190$ & Luro et al. (2008) \\
\hline JK-taa15 & none & 1 & 119.73 & 59.07 & $188-192$ & $164-168$ & Kijas et al. (1997) \\
\hline mCrCIR02D09 & FR677569 & 2 & 11.37 & 45.50 & $230-238$ & $233-248$ & Cuenca et al. (2011) \\
\hline 2P25198777 & Ciclev10015267m. & 2 & 67.6 & 10.73 & A-A & G-A & Curk et al. (2015) \\
\hline JK-TAA41 & none & 2 & 131.86 & 74.99 & $147-154$ & $132-170$ & Kijas et al. (1997) \\
\hline mCrCIR04F12 & FR692369 & 3 & 29.66 & 60.93 & $261-263$ & 263-259 & Ollitrault et al. (2012) \\
\hline CIBE1644 & ET097780 & 3 & 70.23 & 20.36 & $346-364$ & $350-368$ & Ollitrault et al. (2010) \\
\hline JITC01 & CK934237 & 3 & 109.68 & 19.09 & $333-347$ & 349-335 & (Ollitrault et al., 2012b) \\
\hline MEST131 & DY276912 & 3 & 179.4 & 88.81 & $141-147$ & $141-124$ & Garcia-Lor et al. (2012a) \\
\hline MEST070 & DY268779 & 4 & 4.25 & 11.89 & $218-220$ & $224-193$ & in preparation \\
\hline CID6458 & ET086604 & 4 & 15.88 & 0.259 & 385-397 & $397-388$ & Ollitrault et al. (2012a) \\
\hline mCrCIR07D06 & FR677581 & 4 & 16.33 & 0.19 & $165-188$ & $172-167$ & Cuenca et al. (2011) \\
\hline mCrCIR03G05 & FR677578 & 4 & 75.06 & 58.92 & $226-228$ & 219-215 & Cuenca et al. (2011) \\
\hline mCrCIR07G11 & AM489751 & 5 & 20.2 & 2.92 & $202-210$ & 208-145 & Froelicher et al. (2008) \\
\hline $\mathrm{cms} 30$ & none & 5 & 36.84 & 13.72 & $152-156$ & $150-154$ & Ahmad et al. (2003) \\
\hline mCrCIR01F08 & AM489737 & 5 & 54 & 30.88 & $118-118$ & $131-128$ & Froelicher et al. (2008) \\
\hline mCrCIR04H12 & FR692371 & 6 & 0 & 6.4 & $160-160$ & $166-178$ & Ollitrault et al. (2012) \\
\hline $6 \mathrm{P} 7496245$ & Ciclev10013603m. & 6 & 6.3 & 0.1 & $\mathrm{C}-\mathrm{C}$ & G-C & Curk et al. (2015) \\
\hline MEST488 & DY297637 & 6 & 68.48 & 62.08 & $126-130$ & $120-128$ & Garcia-Lor et al. (2012a) \\
\hline PSY-C461 & AB037975 & 6 & 69.72 & 63.32 & A-A & $\mathrm{T}-\mathrm{A}$ & Ollitrault et al. (2012b) \\
\hline AOC-C593 & DY293375 & 6 & 89.88 & 83.48 & $\mathrm{~T}-\mathrm{T}$ & A-T & Ollitrault et al. (2012b) \\
\hline MEST107 & DY274062 & 7 & 8.899 & 87.531 & $175-183$ & $175-181$ & Garcia-Lor et al. (2012a) \\
\hline DXS-C545 & Ciclev10024949m. & 7 & 40 & 56.43 & G-G & C-G & Garcia-Lor et al. (2013b) \\
\hline mCrCIR03B07 & FR677573 & 7 & 83.39 & 13.04 & 263-265- & 273-277 & Cuenca et al. (2011) \\
\hline$\underset{\sim}{\mathrm{mCrCIR} 01 \mathrm{~F} 04}$ & AM489736 & 8 & 5.92 & 48.29 & $186-202$ & $202-171$ & Froelicher et al. (2008) \\
\hline CiBE0214 & ET088913 & 8 & 40.41 & 13.8 & 313-324 & 316-307 & Ollitrault et al. (2010) \\
\hline 8P18684429 & Ciclev10028449m. & 8 & 55 & 0.79 & $\mathrm{C}-\mathrm{C}$ & $\mathrm{T}-\mathrm{C}$ & Curk et al. (2015) \\
\hline mCrCIR02A09 & FR677568 & 8 & 98.63 & 44.42 & $160-163$ & $163-178$ & Cuenca et al. (2011) \\
\hline $\mathrm{Ci02B07}$ & AJ567403 & 9 & 0 & 52.16 & $163-165$ & $165-154$ & Froelicher et al. (2008) \\
\hline mCrCIR07F11 & FR677567 & 9 & 49.57 & 2.59 & $152-160$ & $168-158$ & Kamiri et al. (2011) \\
\hline JI-TCT01 & CV704385 & 9 & 52.8 & 0.64 & $148-154$ & $145-148$ & in preparation \\
\hline $\mathrm{Ci} 08 \mathrm{C} 05$ & AJ567415 & 9 & 55.14 & 2.98 & $154-175$ & $135-152$ & Froelicher et al. (2008) \\
\hline 9P31143176 & Ciclev10006644m. & 9 & 88 & 35.84 & A-A & A-G & Curk et al. (2015) \\
\hline
\end{tabular}

1: Alleles. The numbers indicate the size of alleles in nucleotides for SSR markers and letters correspond to SNP markers alleles.

2: The first allele is the one inherited from C. medica and the second one from C. micrantha

For markers with total allelic differentiation between parents $\left(\mathrm{A}_{1} \mathrm{~A}_{1} \mathrm{~A}_{2} \mathrm{~A}_{2} \times \mathrm{A}_{3} \mathrm{~A}_{3} \mathrm{~A}_{4} \mathrm{~A}_{4}\right.$ and $\mathrm{A}_{1} \mathrm{~A}_{1} \mathrm{~A}_{1} \mathrm{~A}_{1} \times \mathrm{A}_{2} \mathrm{~A}_{2} \mathrm{~A}_{3} \mathrm{~A}_{3}$ ), the genotype of the diploid gamete from 'Mexican' lime was inferred directly from the presence/absence of the specific alleles of the 
'Mexican' lime in the hybrid. When the male and female genitor shared one allele $\left(\mathrm{A}_{1} \mathrm{~A}_{1} \mathrm{~A}_{1} \mathrm{~A}_{1} \times \mathrm{A}_{1} \mathrm{~A}_{1} \mathrm{~A}_{2} \mathrm{~A}_{2}\right.$ and $\left.\mathrm{A}_{1} \mathrm{~A}_{1} \mathrm{~A}_{2} \mathrm{~A}_{2} \times \mathrm{A}_{2} \mathrm{~A}_{2} \mathrm{~A}_{3} \mathrm{~A}_{3}\right)$, the inference of the diploid male gamete structure was carried out from the estimated allele dosage in the tetraploid hybrid. For markers with $\mathrm{A}_{1} \mathrm{~A}_{1} \mathrm{~A}_{1} \mathrm{~A}_{1} \times \mathrm{A}_{1} \mathrm{~A}_{1} \mathrm{~A}_{2} \mathrm{~A}_{2}$ configuration, $\mathrm{A}_{1} \mathrm{~A}_{1}, \mathrm{~A}_{1} \mathrm{~A}_{2}$ and $A_{2} A_{2}$ male gametes were inferred respectively from $A_{1} A_{1} A_{1} A_{1}, A_{1} A_{1} A_{2} A_{2}$ and $\mathrm{A}_{1} \mathrm{~A}_{1} \mathrm{~A}_{2} \mathrm{~A}_{2}$ hybrid genotypes. For markers with $\mathrm{A}_{1} \mathrm{~A}_{1} \mathrm{~A}_{2} \mathrm{~A}_{2} \times \mathrm{A}_{2} \mathrm{~A}_{2} \mathrm{~A}_{3} \mathrm{~A}_{3}$ allelic configuration, the potential nine combinations of the two parental diploid gametes produce nine tetraploid hybrids genotypes totally differentiated by allele doses; $\mathrm{A}_{1} \mathrm{~A}_{1} \mathrm{~A}_{2} \mathrm{~A}_{2}, \mathrm{~A}_{1} \mathrm{~A}_{1} \mathrm{~A}_{2} \mathrm{~A}_{3}, \mathrm{~A}_{1} \mathrm{~A}_{1} \mathrm{~A}_{3} \mathrm{~A}_{3}, \mathrm{~A}_{1} \mathrm{~A}_{2} \mathrm{~A}_{2} \mathrm{~A}_{2}, \mathrm{~A}_{1} \mathrm{~A}_{2} \mathrm{~A}_{2} \mathrm{~A}_{3}, \mathrm{~A}_{1} \mathrm{~A}_{2} \mathrm{~A}_{3} \mathrm{~A}_{3}, \mathrm{~A}_{2} \mathrm{~A}_{2} \mathrm{~A}_{2} \mathrm{~A}_{2}$, $\mathrm{A}_{2} \mathrm{~A}_{2} \mathrm{~A}_{2} \mathrm{~A}_{3}$ and $\mathrm{A}_{2} \mathrm{~A}_{2} \mathrm{~A}_{3} \mathrm{~A}_{3}$. The male diploid gametes inferred from these tetraploid hybrid genotypes were respectively, $\mathrm{A}_{2} \mathrm{~A}_{2}, \mathrm{~A}_{2} \mathrm{~A}_{3}, \mathrm{~A}_{3} \mathrm{~A}_{3}, \mathrm{~A}_{2} \mathrm{~A}_{2}, \mathrm{~A}_{2} \mathrm{~A}_{3}, \mathrm{~A}_{3} \mathrm{~A}_{3} \mathrm{~A}_{2} \mathrm{~A}_{2}$, $\mathrm{A}_{2} \mathrm{~A}_{3}$ and $\mathrm{A}_{3} \mathrm{~A}_{3}$.

\section{Statistical analysis of preferential pairing}

Stift et al. (2008) proposed a segregation model to interpret the inheritance model in allotetraploid citrus. Aleza et al. (2016a) simplified it for the doubled diploid, considering that the expected gamete frequencies only depends of the 'tetrasomic' parameter $(\tau)$ corresponding to the proportion of gametes formed by random meiotic chromosome associations (random bivalent or tetravalent pairing) taking values from zero (full disomic) to one (full tetrasomic). $\tau$ was estimated by a maximum likelihood approach as proposed by Aleza et al. (2016a), from the analysis of the closet marker to the centromere for each chromosome. Having $\tau$ value estimation for each chromosome, the preferential pairing (PP) was calculated as $1-\tau$. Parental heterozygosity restitution (PHR), was calculated for each marker as the percentage of inferred heterozygous diploid gametes.

\section{Genetic mapping}

With the objective to study the interspecific recombination ( $C$. medica / C. micrantha) at tetraploid level we anchored the LGs inferred from the 'Mexican' lime diploid gametes on the reference clementine genome sequence (https://phytozome.jgi.doe.gov/pz/portal.html) and compare it with genetic maps of clementine at diploid and tetraploid level, also anchored in the reference sequence. The diploid clementine genetic map (Ollitrault et al., 2012b) was used as reference map for Citrus for the reference sequence assembly (Wu et al., 2014). For the tetraploid clementine map we used the 57 molecular markers segregation analysis published by Aleza et al. (2016a). For tetraploid 'Mexican' lime 34 out of the 35 markers analysed for this study were used. Indeed, the SNP marker (8P18684429) showed no segregation with $100 \%$ of heterozygosity. Each tetraploid progeny was analysed with Tetraploid Map Software (Hackett et al., 2007) using the default parameters to establish the different map distances in $\mathrm{cM}$.

Then, the genetic and physical maps were drawn using the MapChart program (Voorrips, 2002). To anchor the genetic maps in the physical sequence, we divided the physical position by 300.000 in order to obtain comparable drawing sizes. 


\section{$\underline{\text { Results }}$}

\section{Pollen viability and Cytogenetic analysis}

A total of 1.179 pollen grain were observed and $64 \%$ of pollen viability was recorded (Figure 3.1).

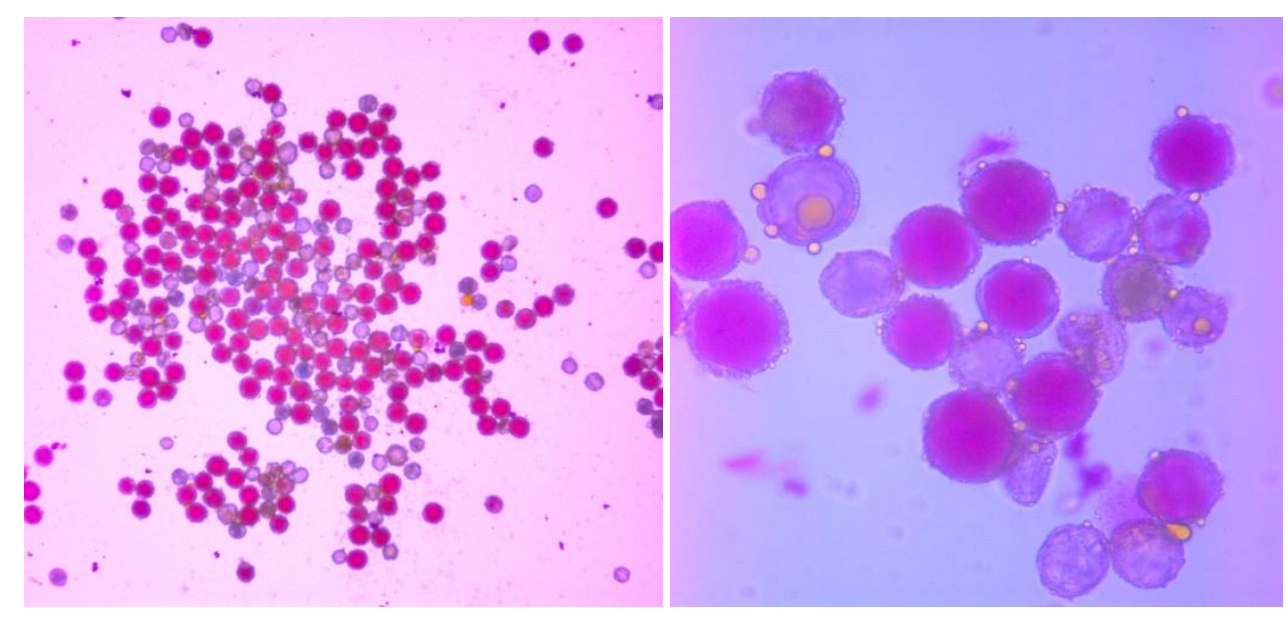

Figure 3.1. Pollen grains of tetraploid 'Mexican' lime stained with aceto-carmine. Bold red color are viable and colorless (blue) are non-viable.

As for the cytogenetic observations, two thirds of the chromosomes paired in bivalent (Figures 3.2a and 3.2b and Table 3.2). The majority of the other chromosomes paired in tetravalents.

Table 3.2. Chromosome configuration at meiosis in pollen mother cells (PMC) of the tetraploid 'Mexican' lime

\begin{tabular}{lccccc}
\hline & Univalents & Bivalents & Trivalents & \multicolumn{2}{c}{ Tetravalents } \\
& & & & Ring & Chain \\
\hline Number of asociation structures & 21 & 597 & 15 & 29 & 115 \\
Percentage of involved chromosomes & 1.14 & 65.03 & 2.45 & 6.32 & 25.05 \\
Average number of configuration by PMC & 0.41 & 11.71 & 0.29 & 0.57 & 2.25 \\
\hline
\end{tabular}

Two types of tetravalents, closed and chain, were distinguishable. Chain tetravalent configuration concerned $25.05 \%$ of the chromosomes and closed tetravalents $6.32 \%$ (Figure 3.2, c, d). The average number of bivalent and tetravalent configurations by PMC was respectively 11.71 and 2.82. In contrast, occurrence of monovalent and trivalent configuration by PMC was very low (mean of 0.41 and 0.29 respectively per $\mathrm{PMC})$. 

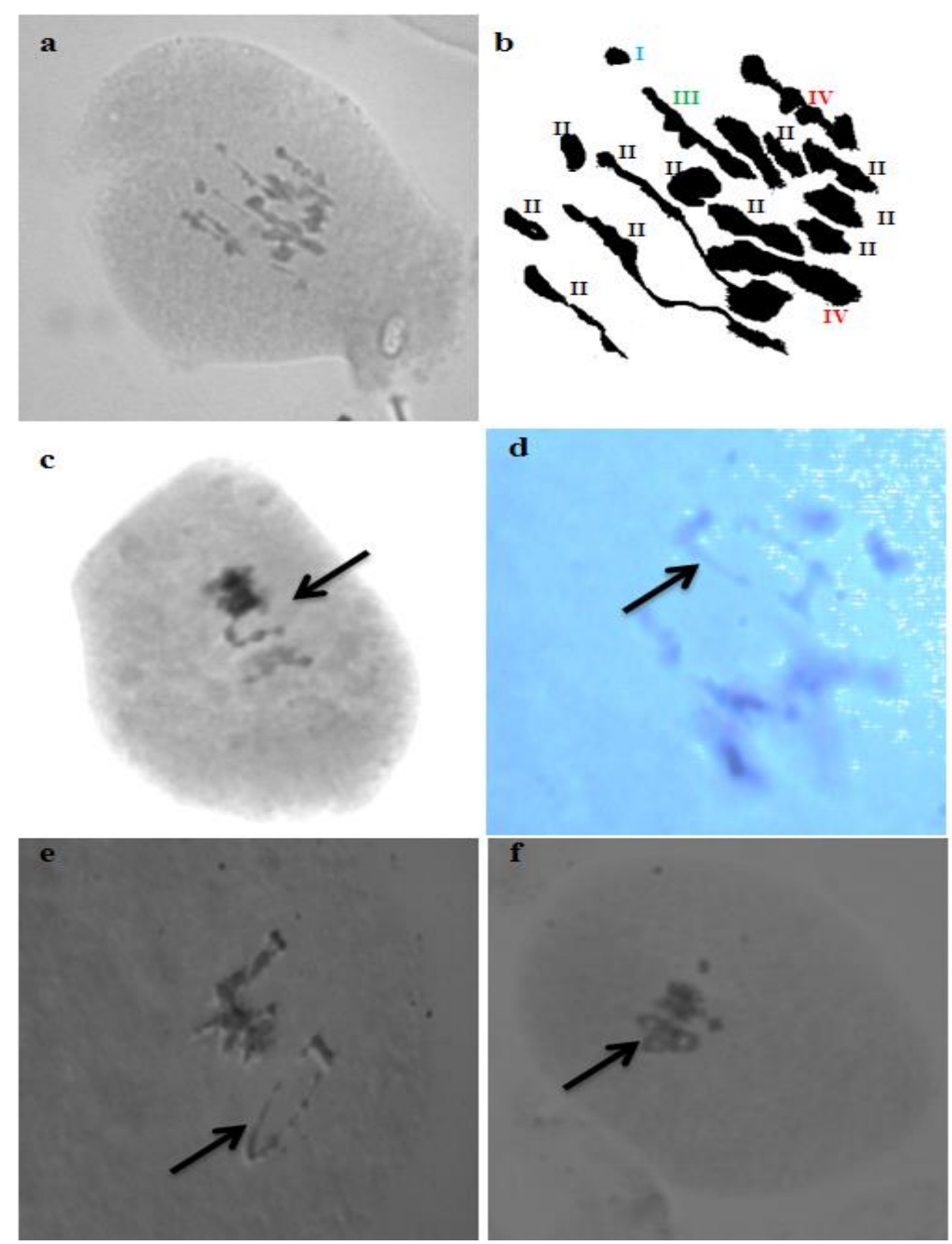

Figure 3.2. Chromosome pairing configuration, a: Pollen Mother Cells (PMC) of the tetraploid 'Mexican' lime. b, Schematic interpretation of (a) 1 univalent (blue colour) + 12 bivalents (black colour) +1 trivalent (green colour) +2 tetravalents (red colour). c, Open tetravalent (arrow). d, e, f closed (ring) tetravalents (arrows).

The analysis of configuration at individual PMC level (Figure 3.3) revealed at least eight bivalents and two tetravalents for each PMC. The occurrence of twelve bivalents / PMC, was the most frequent situation (19 PMC) with a maximum of 14 bivalents observed in 13 PMC. Up to four tetravelents /PMC were found in 14 PMC. Two PMC exhibited only two monovalents and 15 PMC showed at least one monovalent and one trivalent. 


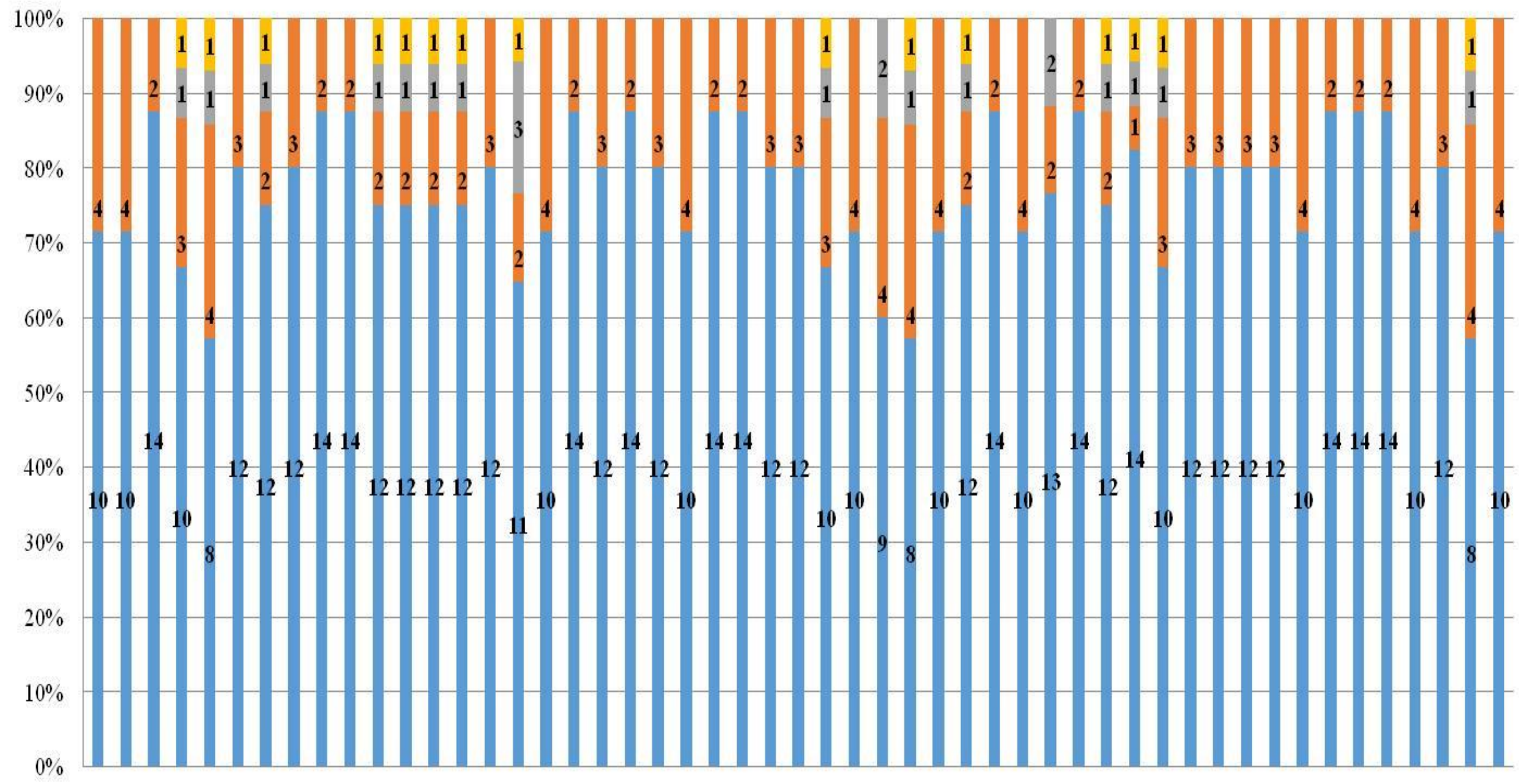

$12334556 \quad 7 \quad 8 \quad 9101112131415161718192021222324252627282930313233343536373839404142434445464748495051$ Bivalent - Tetravalents

- Monovalents

- Trivalents

Figure 3.3. Individual meiotic configuration of each observed PMC for tetraploid 'Mexican' lime. 
Monovalents and trivalents may be interpreted as a broken tetravalent or incomplete tetravalent pairing by the absence of chiasma on its two arms (Jeredi et al., 2012). Under this hypothesis three configurations were predominant, 12 bivalents / 3 tetravalents (18 PMC; 35\%), 14 bivalents / 2 tetravalents (13 PMC; 25\%) and 10 bivalents $/ 4$ tetravalents (13 PMC; 25\%).

\section{Molecular markers analysis}

Eighty five plants were obtained from the Clementine $4 \mathrm{x} x$ 'Mexican' lime hybridization. Ploidy analysis by flow cytometry demonstrated that all were tetraploids. They were analysed with two SSR markers, mCrCIR07F11 and MEST001, displaying a total differentiation between the parents, to study their genetic origin. For each marker, at least one specific allele of 'Mexican' lime was observed in all plants. Moreover, in many plants the two specific alleles of 'Mexican' lime were observed in combination with clementine alleles (Figure 3.4a). The Cl4x x ML4x hybrid origin of all analyzed plants was thus confirmed.
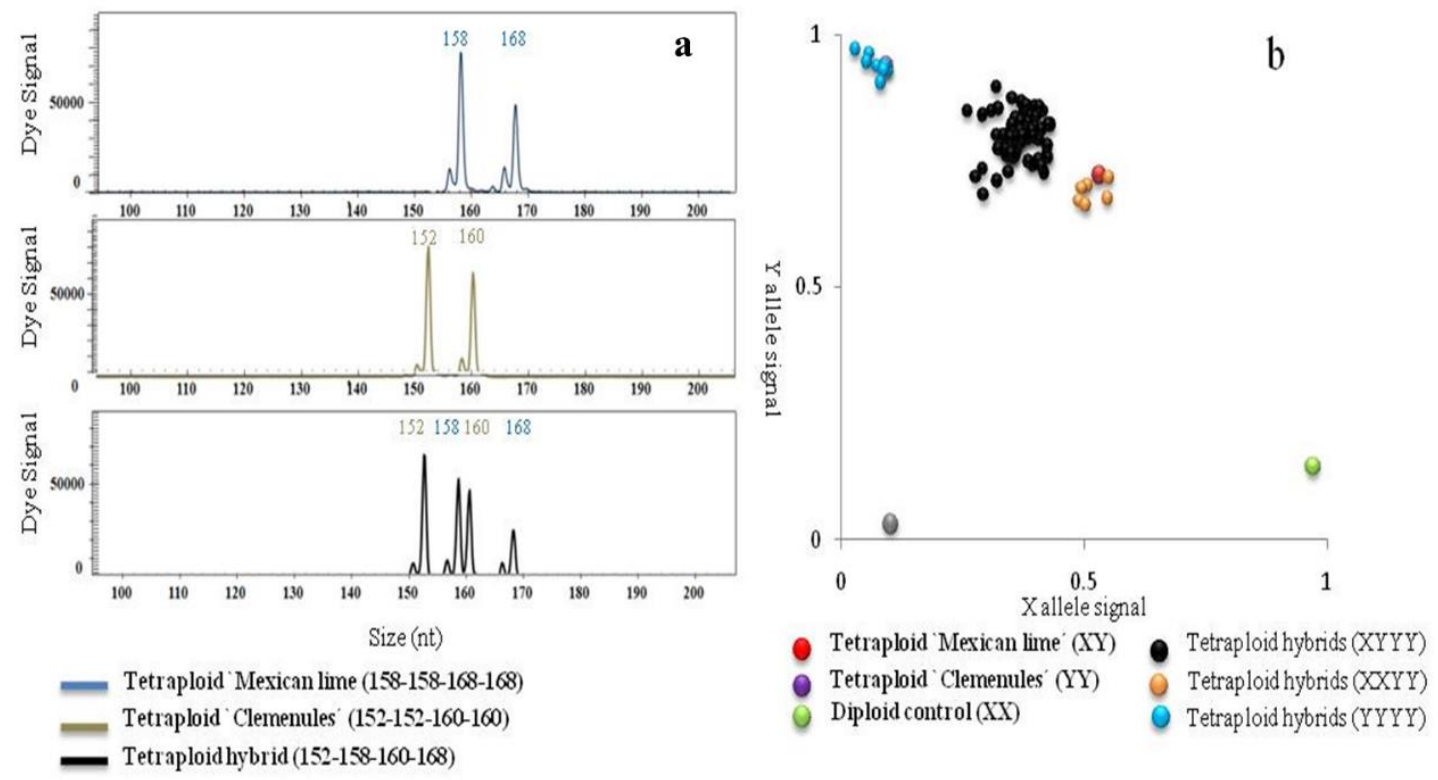

Figure 3.4. Illustration of tetraploid hybrids genotyping. a. Electroferogram of a tetraploid hybrid recovered from hybridization between tetraploid Clemenules 'clementine and tetraploid 'Mexican' lime with mCrCIR07F11 SSR marker. nt : nucleotides. b. Plot of X and Y allele signals of the 1P199494 SNP marker representing tetraploid hybrids from the same hybridization. Letters indicate the allelic configuration for each genotype.

These 85 hybrids were analysed with 35 codominant markers and the 'Mexican' lime diploid gamete genotypes and their phylogenomic structure (C. micrantha or $C$. medica homozygosity and interspecific heterozygosity) were inferred (Additional Table 3.1). On average, for all the loci, a 90.2\% of PHR has been observed (Table 3.3; Additional Table 3.1) and varied between $82.7 \%$ for the LG05 and $95.6 \%$ for LG08 (Table 3.3). At individual marker level (Figure 3.5.a; Additional Table 3.1), PHR varied between 
$74.1 \%$ and $100 \%$ for mCrCIR04F12 (LG03) and 8P18684429 (LG08) markers respectively.

A slight diminution of PHR is observed in most LGs from centromeric to telomeric markers. As an example, for LG01, the PHR values were $92.9 \%$ and $94.1 \%$ for the two centromeric SSR markers, CIBE5720 and MEST001 respectively, and only decrease to $85.9 \%$ and $88.2 \%$ for the telomeric markers 1P199494 and JK-TAA15 respectively. This reduction could be associated with DR in case of tetravalent associations.

At individual gamete level PHR displayed a unimodal distribution and varied between 0.66 and 1; six gametes were fully heterozygous and $58.8 \%$ of diploid gametes displayed a PHR value over 90\%. (Figure 3.5.b; Additional Table 3.1).
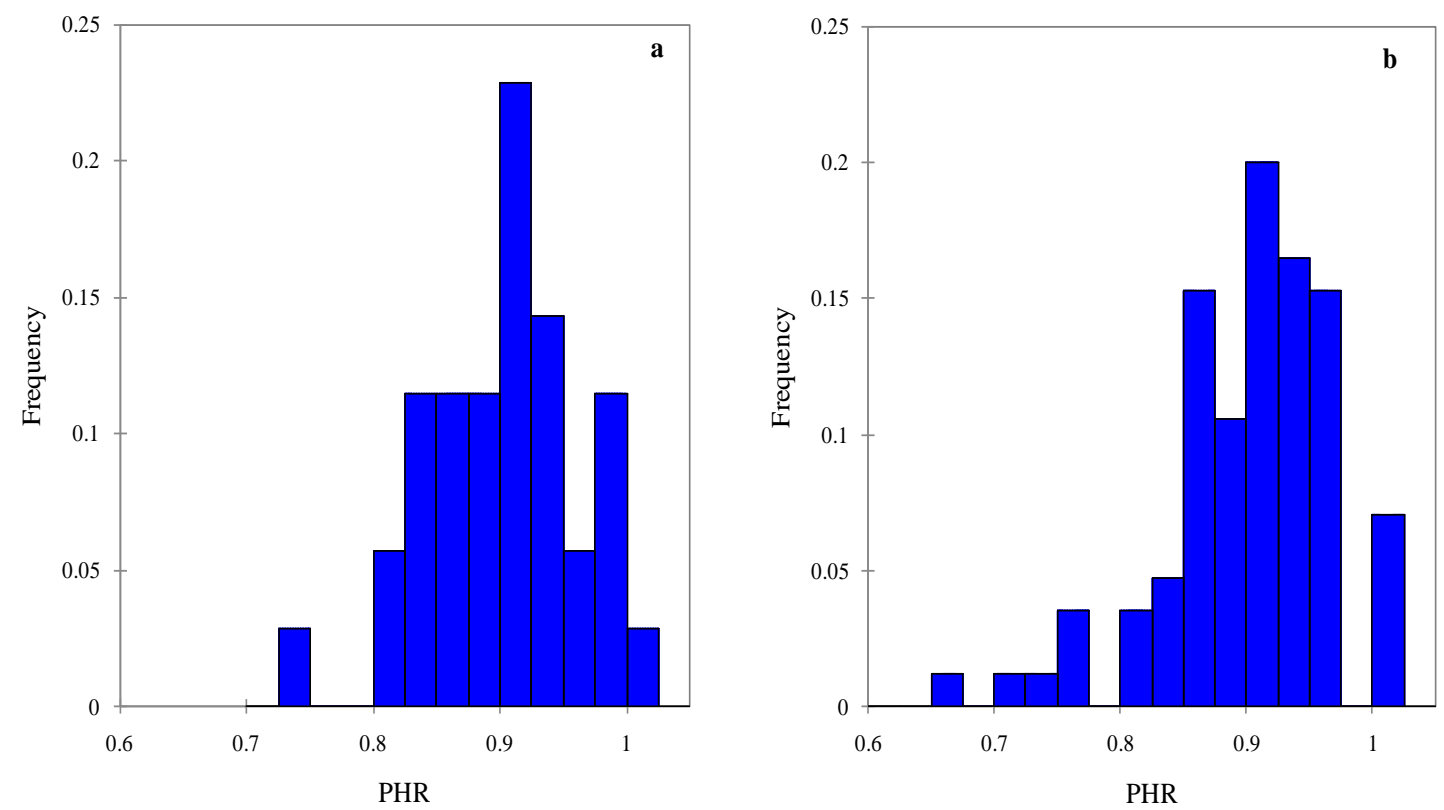

Figure 3.5. Distribution of PHR values among markers (a) and gametes (b) for diploid gametes obtained from tetraploid 'Mexican' lime.

Over all loci and gametes, the percentages of $C$. micrantha and $C$. medica homozygosity were $4.7 \%$ and $5.1 \%$ respectively. When analysing more deeply the data at gamete level (Table 3.3; Additional Table 3.1) it appeared that the majority $(77.8 \%)$ of individual LGs of the different hybrids were fully heterozygous. For the considered markers six hybrids resulted from fully heterozygous gametes. At the opposite, only nine $(1.2 \%)$ and six $(0.8 \%)$ fully homozygous LGs for C. micrantha and C. medica respectively were observed. $20.26 \%$ of the individual LGs displayed mixed structure with homozygosity and heterozygosity and all the nine citrus LGs were concerned. Homozygous and mixed LGs reveal pairing of $C$. micrantha and $C$. medica chromosomes and mixed LGs testify for interspecific recombination. The number of LGs with homozygosity for both markers (if available) flanking the centromere was low $(5.23 \%)$ and varied between chromosomes, from $12.9 \%$ in LG05 to lower value than $0.01 \%$ for LG03, LG07 and LG08. 
Table 3.3. Interspecific structures of the 'Mexican' lime diploid gametes for the nine LGs

\begin{tabular}{lccccc}
\hline & PHR & FH & Fmed & Fmic & Mixed \\
\hline LG1 & 90.3 & 76.5 & 2.4 & 1.2 & 20.0 \\
LG2 & 95.3 & 90.6 & 0.0 & 0.0 & 9.4 \\
LG3 & 85.0 & 57.6 & 1.2 & 0.0 & 41.2 \\
LG4 & 89.7 & 77.6 & 1.2 & 1.2 & 20.0 \\
LG5 & 82.7 & 72.9 & 2.4 & 4.7 & 20.0 \\
LG6 & 88.0 & 80.0 & 0.0 & 3.5 & 16.5 \\
LG7 & 92.9 & 82.4 & 0.0 & 0.0 & 17.6 \\
LG8 & 95.6 & 82.4 & 0.0 & 0.0 & 17.6 \\
LG9 & 92.0 & 80.0 & 0.0 & 0.0 & 20.0 \\
Total & $\mathbf{9 0 . 2}$ & $\mathbf{7 7 . 8}$ & $\mathbf{0 . 8}$ & $\mathbf{1 . 2}$ & $\mathbf{2 0 . 3}$ \\
\hline
\end{tabular}

FH: percentage of fully heterozygous gametes for the LG; Fmed: percentage of fully C. medica homozygous gametes for the LG; Fmic: percentage of fully $C$. micrantha homozygous gametes for the LG; Mixed: percentage of gametes with mixed heterozygosity and homozygosity for the LG.

\section{Estimation of preferential association frequency}

$\tau$ and PP were estimated from the likelihood models (Table 3.4), for each LG. Disomic inheritance with high preferential pairing values was observed for LG07 and LG08 $(\mathrm{PP}=0.965)$ and LG02 $(\mathrm{PP}=0.86)$. Tendency for preferential pairing was found for LG01, LG03, LG04, LG06, and LG09 (0.68< PP < 0.79). For LG05 the intermediate model fitted better than disomic or tetrasomic models $(\mathrm{PP}=0.50)$.

Table 3.4. Estimation of $\tau$ and PP from centromeric loci of the nine LG of 'Mexican' lime $4 \mathrm{x}$

\begin{tabular}{llcccccc}
\hline LG & \multicolumn{1}{c}{ Locus } & DC & Mic/Mic & Med/Mic & Med/Med & $\boldsymbol{\tau}$ & PP \\
\hline 1 & Cibe5720 & 2.21 & 1 & 79 & 5 & 0.210 & 0.790 \\
2 & 2P25198777 & 10.73 & 1 & 81 & 3 & 0.140 & 0.860 \\
3 & JITC01 & 19.09 & 1 & 78 & 6 & 0.245 & 0.755 \\
4 & mCrCIR07D06 & 0.19 & 3 & 79 & 3 & 0.210 & 0.790 \\
5 & mCrCIR07G11 & 2.93 & 7 & 71 & 7 & 0.495 & 0.505 \\
6 & 6P7496245 & 0.10 & 4 & 76 & 5 & 0.320 & 0.680 \\
7 & mCrCIR03B07 & 13.04 & 0 & 84 & 1 & 0.035 & 0.965 \\
8 & CiBE0214 & 13.80 & 0 & 84 & 1 & 0.035 & 0.965 \\
9 & JI-TCT01 & 0.64 & 0 & 78 & 7 & 0.245 & 0.755 \\
\hline
\end{tabular}

LG: Linkage Group; DC: Distance to the centromere (from reference genetic map data Ollitrault et al. 2012b - and location of centromere - Aleza et al. 2015). Med/Med, Med/Mic and Mic/mic: Number of individuals with such allelic configuration; $\tau$ : Tetrasomic rate; PP: Preferential Pairing 


\section{Genetic mapping and recombination rate analysis}

The genetic maps were established from SSR and SNP marker segregations and then compared using the physical positions as common references (Figure 3.6). The average recombination rates by $\mathrm{Mb}$ were estimated for each $\mathrm{LG}$ and each population considering the extreme marker positions in the genetics maps and the physical one (Table 3.5).

Table 3.5. Average recombination rates per $\mathrm{LG}(\mathrm{cM} / \mathrm{Mb})$ for three segregating progenies

\begin{tabular}{lccc}
\hline & $\begin{array}{c}\mathbf{2 x} \\
\text { Clementine }\end{array}$ & $\begin{array}{c}\mathbf{4 x} \\
\text { Clementine }\end{array}$ & $\begin{array}{c}\mathbf{4 x} \mathbf{x}^{` M e x i c a n} \\
\text { lime }\end{array}$ \\
\hline LG1 & 3.53 & 2.99 & 0.82 \\
LG2 & 3.97 & 4.65 & 0.31 \\
LG3 & 2.79 & 3.46 & 1.88 \\
LG4 & 3.37 & 3.53 & 1.28 \\
LG5 & 2.64 & 2.42 & 1.68 \\
LG6 & 3.51 & 3.78 & 1.07 \\
LG7 & 5.49 & 3.49 & 2.12 \\
LG8 & 4.12 & 3.40 & 1.16 \\
LG9 & 2.63 & 3.30 & 0.94 \\
Total & 3.29 & 3.41 & 1.21 \\
\hline
\end{tabular}

LG: Linkage Group

For the diploid clementine genetic and physical maps, the considered positions were the ones published respectively by Ollitrault et al. (2012b) and $\mathrm{Wu}$ et al. (2014). Those maps where used to compare the results of both tetraploid genetic maps. For the genetic maps, only the markers common with the tetraploid clementine mapping were selected. For the physical map we retained the previous markers plus the ones of the tetraploid 'Mexican' lime map.

For tetraploid clementine map, the positions of 57 molecular markers of tetraploid clementine published previously by Aleza et al. (2016a) were inferred. The map size was $864 \mathrm{cM}$. Compared with the clementine genetic map, the synteny was complete and the order of markers conserved except for very close telomeric markers in LG02 and LG06. Genetic distances of the two clementine maps were very similar with average rates of 3.29 and $3.41 \mathrm{cM} / \mathrm{Mb}$ for the diploid and tetraploid clementine and limited variations between linkage groups.

For tetraploid 'Mexican' lime map, the 34 segregating molecular markers of the present study (8P18684429 marker was heterozygous for the 85 analyzed hybrids) where mapped. The map spanned only $272 \mathrm{cM}$. The majority of the markers conserved the same order than in the clementine physical map, although three inversions were observed on LG02, LG04 and LG06. The distances between markers were considerably lower than in the diploid and tetraploid clementine maps. Indeed, the average rate of recombination of the tetraploid 'Mexican' lime was $1.21 \mathrm{cM} / \mathrm{Mb}$, a third than the one observed for the diploid and tetraploid clementine. 

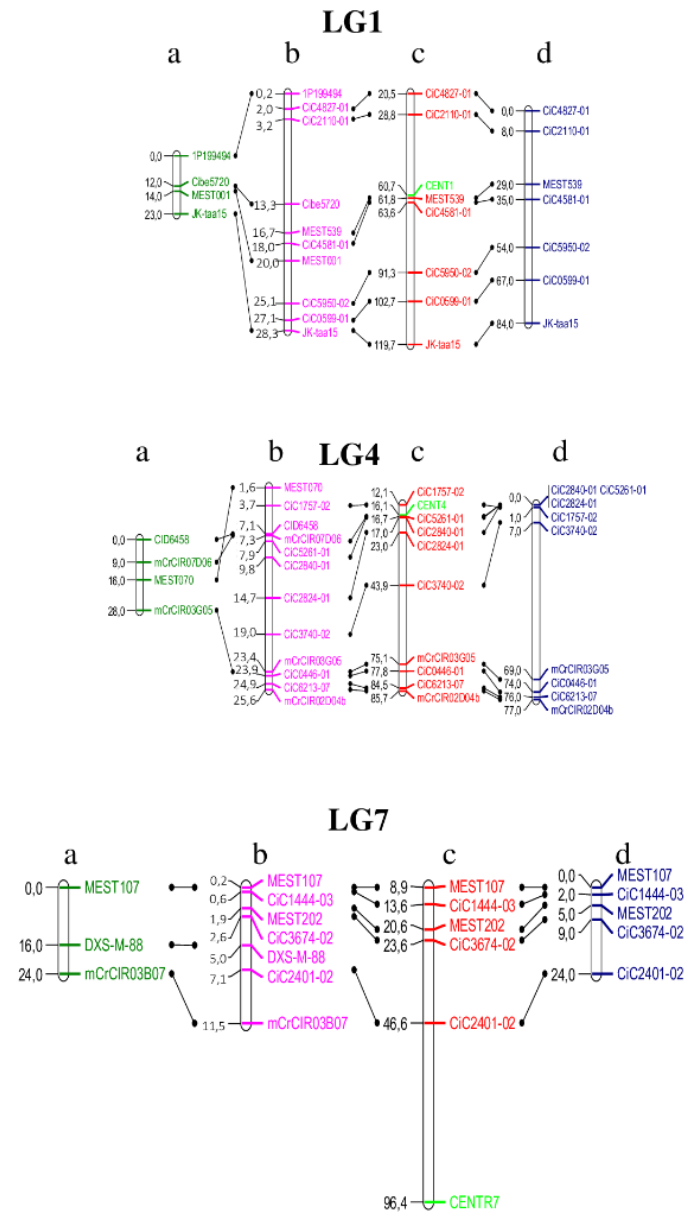
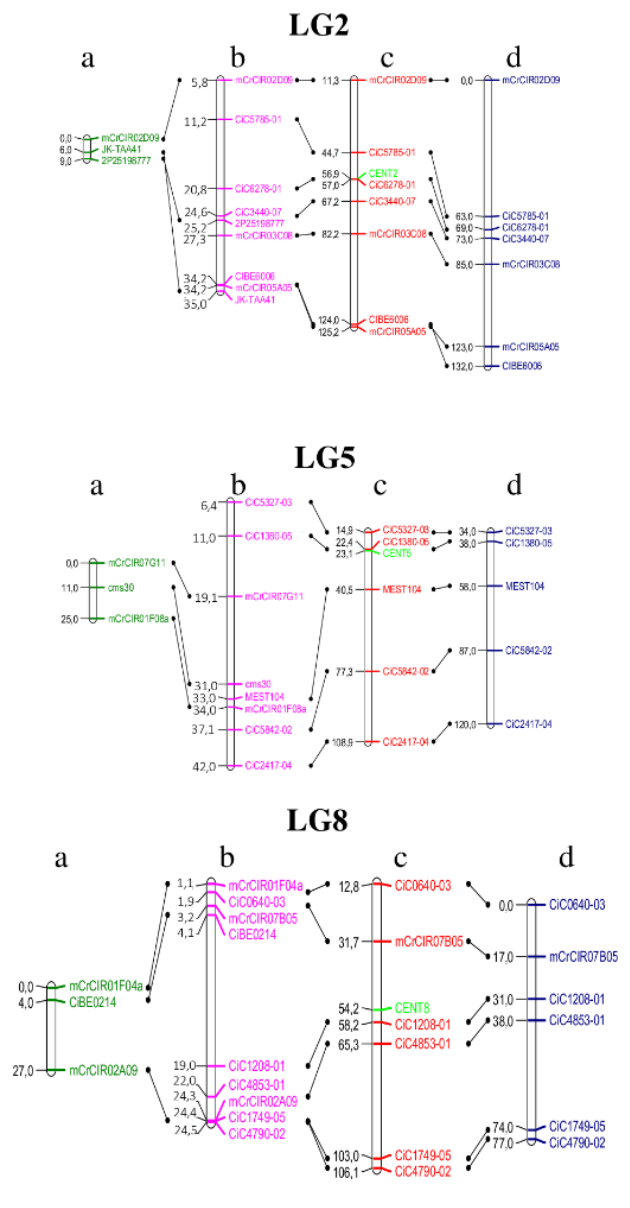
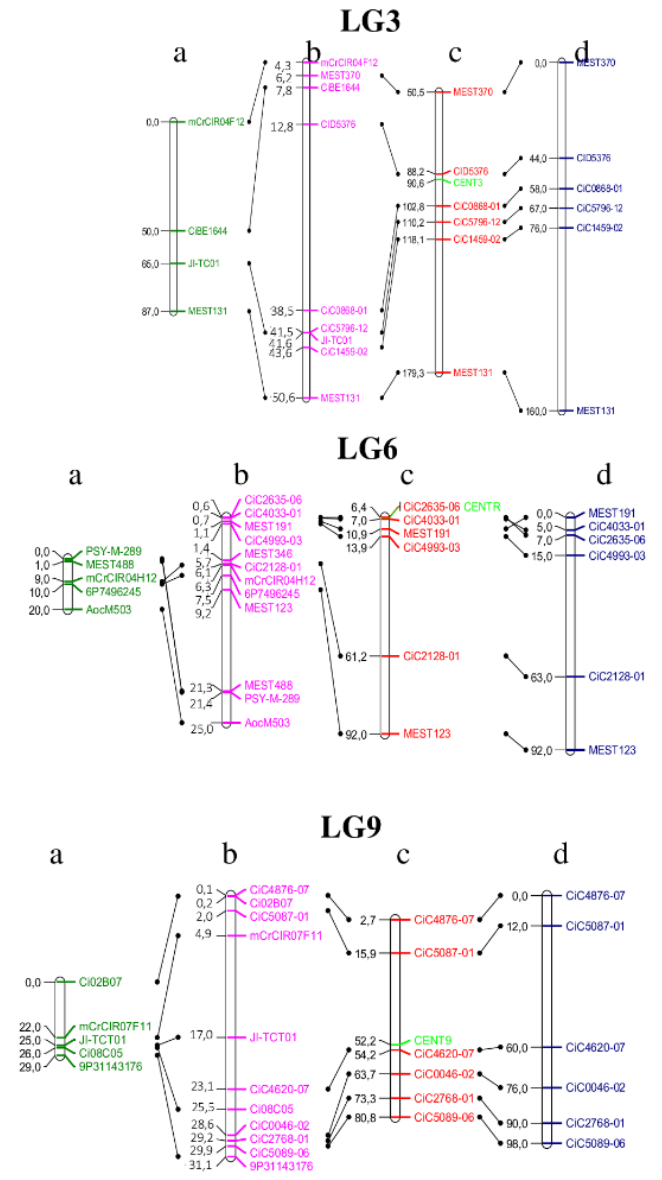

Figure 3.6. Comparative mapping between tetraploid 'Mexican' lime and diploid and tetraploid 'Clemenules' a: Tetraploid 'Mexican' lime (cM); b: diploid Clementine (physical; Mb); c: diploid Clementine (genetics; cM); d: tetraploid Clementine (cM). The centromere of each linkage group is indicated in green in the diploid Clementine map. 


\section{Discussion}

\section{Meiotic behavior of the doubled diploid `Mexican’ lime revealed by cytogenetics}

Asynapsis, dependent to low temperature, has been described in diploid 'Mexican' lime (Iwamasa et al., 1962). No evidence of such configuration was observed for the tetraploid 'Mexican' lime. Indeed, the very low rate of monovalents observed during the microsporogenesis indicates that such meiosis abnormality was not induced in the tetraploid lime cultivated in Spain. The asynaptic behavior of chromosomes was recorded at temperatures lower than $10^{\circ} \mathrm{C}$ (Iwamasa and Iwasaki, 1963) while our sampling was made at temperature over $16^{\circ} \mathrm{C}$.

A common approach to distinguish autotetraploids from allotetraploids is to evaluate the frequency of tetravalent formation. In genuine autotetraploids, about two third of the chromosomes are usually involved in tetravalent configurations (Morrison Rajhathy, 1960). However, it has to be used with caution since genetic systems of diploidization or preferential pairing could exist.

The predominance of bivalents $(65 \%)$ in the meiosis of tetraploid 'Mexican' lime is similar with the observations made in several allotetraploid somatic hybrids, like $C$. deliciosa $+C$. limon (Kamiri et al., 2011), C. sinensis $+C$. limon (Del Bosco et al., 1999; Chen et al., 2004), and Tangelo (C. reticulata x $C$. paradisi) $+C$. grandis (Xie et al., 2015). They also revealed tetravalent formation and a low percentage of monovalents and trivalents. In some species, homoeologous pairing can be under genetic control (Cifuentes et al., 2010). However, multivalent frequency in tetraploids is usually related with the pairing affinity (Jeredi et al., 2012). Length of chromosomes and position of the centromere may also influence the multivalent frequencies (McCollum, 1958).

Structural variations strongly affect chromosome pairing. A large heterozygous inversion was described in diploid 'Mexican' lime (Iwamasa and Nito 1988). Its frequency attained 44\%, indicating large inverted segment resulting in partial sterility of gametophytes (Iwamasa, 1966). In Valencia (Spain), the pollen viability of the diploid 'Mexican' lime was estimated to be less than 10\% (Pons et al., 2011). Interestingly we observed $64 \%$ of pollen viability for the DD 'Mexican' lime, higher than the rates ranging from $31 \%$ to $41 \%$, reported by Aleza et al. (2012a) and Del Bosco et al. (1999) for different DD and somatic hybrids. In cases in which sterility of interspecific diploid hybrids is due to improper chromosome pairing, the generation of allotetraploids by chromosome doubling provides a homolog for each chromosome to pair with during meiosis and can allow for the development of fertile gametes (Zadoo et al., 1975; Lu and Bridgen, 1997; van Tuyl and De Jeu, 1997; Contreras et al., 2007).

We observed that $6.3 \%$ of the chromosomes were involved in closed tetravalents. Moreover in some PMC more than one closed tetravalent has been observed. In diploid species, the observation of closed tetravalents is considered an evidence for the presence of heterozygous reciprocal translocation (Sybenga, 1975). Reciprocal translocation is defined as the interchange of part of a chromosome with part of another (Sybenga, 1995) and results in alterations of the meiotic configurations. The affected chromosomes may form a ring or a chain tetravalent structure depending in the rate of the chiasmata (Sybenga, 1975; 2012). In citrus, a reciprocal translocation was described in diploid 'Valencia' and 'Lue Gin Gong' sweet oranges (C. sinensis), for which tetravalents were frequently observed (Iwamasa, 1963). Del Bosco et al. (1999) studied the meiosis of allotetraploid somatic hybrid between 'Valencia' sweet orange and 'Femminello' lemon and revealed that the reciprocal translocation still exist in the 
somatic hybrid. Closed tetravalents were not observed in cytogenetic study of diploid 'Mexican' lime (Iwamasa and Nito, 1988) while inversion(s) were evidenced. A reconciliation between diploid and doubled diploid microsporogenesis data should be the presence of a double inversion affecting the two arms of a same chromosome (Figure 3.7). This double inversion pattern may results from chromosome structural variation between $C$. medica and $C$. micrantha, the two parents of the diploid 'Mexican' lime (Curk et al., 2016).
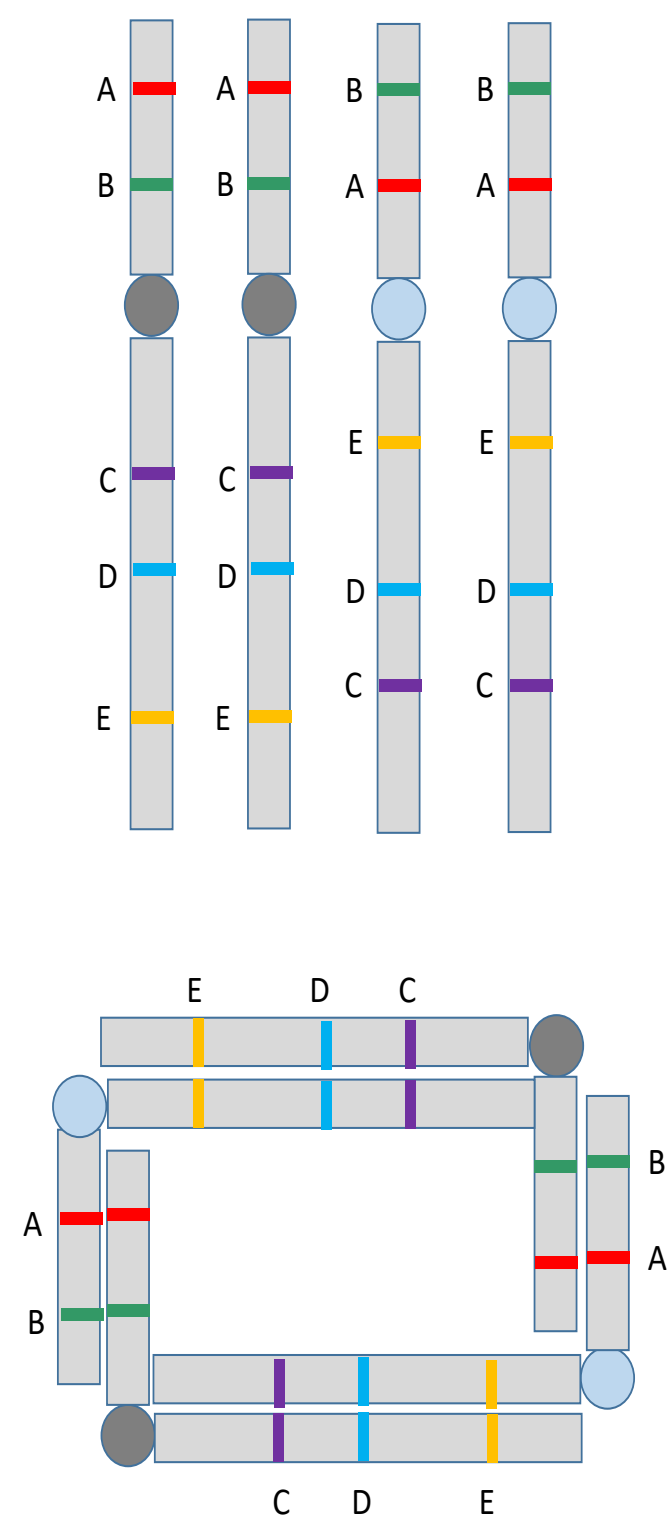

Figure 3.7. Interpretation for reconciliation of microsporogenesis observations in diploid and doubled diploid 'Mexican' lime: double inversion can produce closed tetravalent during doubled diploid meiosis. 


\section{Doubled diploid `Mexican’ lime has an intermediary preferential disomic inheritance}

Froelicher et al. (2000) were the first to analyse the inheritance of a tetraploid Aurantioideae, Clausena excavata using molecular markers. They revealed a strict disomic inheritance. Later, the meiosis behaviour of interspecific somatic hybrids within the Citrus genus has been studied combining cytogenetics and molecular markers analysis (Kamiri et al., 2011; Xie et al., 2015); depending on the parents and chromosomes, intermediate to tetrasomic inheritance were observed. For the DD clementine obtained from colchicine treatment, Aleza et al. (2016a), using molecular markers analysis, observed multivalent pairing and preferential tetrasomic inheritance tendency testifying for non-preferential pairing.

For the DD 'Mexican' lime, the average PHR values reported in this work (90\%) are higher than those observed by Kamiri et al. (2011) who reported PHR values ranging from $54 \%$ to $79 \%$, for a $C$. deliciosa $+C$. limon tetraploid somatic hybrids. Xie et al . (2015) reported $76.2 \%$ of PHR for a somatic hybrid between Tangelo and a pummelo while it was $65 \%$ for a DD clementine (Aleza et al., 2016a). In direct relation with PHR, the preferential pairing rate was high for most LGs for the tetraploid 'Mexican' lime. Disomic inheritance with high preferential pairing values was observed for LG02, LG07 and LG08. Tendency for preferential pairing was found for five LGs (LG01, LG03, LG04, LG06, and LG09). For LG05 the intermediate models fitted better than disomic or tetrasomic model $(\mathrm{PP}=0.50)$. Lower values were estimated by Kamiri et al. (2011) and Aleza et al. (2016a). For instance, for the tetraploid clementine, Aleza et al. (2016a) concluded for non-preferential pairing $(\mathrm{PP}=0)$ for five $\mathrm{LGs}$.

The high fertility of most interspecific hybrids within the citrus genus, excepted 'Mexican' lime at diploid level (Ollitrault and Navarro, 2012) testify for a good pairing affinity and therefore limited chromosomes variations between species. However tetraploid genotypes offer a choice for chromosome partners, not available at diploid level, and therefore can reveal chromosomal variations between ancestral species. The different meiotic behavior observed by Kamiri et al. (2011), Aleza et al. (2016a) and our study can be due to the phylogenomic structure of the different genotype. In case of the $C$. reticulata $+C$. limon studied by Kamiri et al. (2011), it is highly complex as $C$. limon results from $(C$. maxima $\mathrm{x} C$. reticulata) x $C$. medica natural hybridization (Curk et al., 2016). Therefore it harbors a two ancestor heterozygosity (C.ret/C.ret/C.ret/C.med) or three ancestor heterozygosity (C.ret/C.ret/C.max/C.med) at each locus. The DD clementine studied by Aleza et al. (2016a) had a more simple structure with a predominant $C$. reticulata genomic constitution with some genomic segments in C.ret/C.ret/C.max/C.max heterozygosity. C. aurantifolia is a hybrid of two distant species $(C$. micrantha $\mathrm{x}$ C. medica). Therefore, each locus displays C.mic/C.mic/C.med/C.med heterozygosity. Molecular studies (García et al., 2013; Curk et al., 2014; 2015; Carbonell-Caballero et al., 2015) have shown that $C$. medica is the cultivated citrus ancestor most distant to the three other ones. It can be suspected that both sequence divergence and structural variations between $C$. medica and $C$. micrantha drive the preferential pairing and intermediary preferential disomic inheritance observed for the DD 'Mexican' lime. As stated by Stebbins, (1950), the importance of the differentiation may vary between the different sets of chromosomes and should explain the difference of PP rates between the chromosomes. Interestingly in the tetraploid 'Mexican' lime, none of the 9 chromosomes display a tetrasomic inheritance, 
suggesting that pairing is affected by a global differentiation rather than discrete and local large structural variations, as the inversion described in diploid 'Mexican' lime.

\section{Interspecific recombination occurs in each LGs but is strongly lower compared with recombination rates in doubled-diploid clementine}

Despite the disomic tendency, mixed heterozygous/homozygous structures were observed for the nine citrus LGs revealing interspecific recombination between $C$. medica and C. micrantha, the parents of the 'Mexican' lime (Nicolosi et al., 2000; Curk et al., 2016) for the nine citrus chromosomes. For LG05, 12.9\% of the gametes displayed homozygosity both side of the centromere, suggesting higher homology between $C$. micrantha and $C$. medica for the corresponding chromosome than for the others (5.3\% in average). This is confirmed by the conclusion for intermediate preferential pairing for chromosome 5 while the other chromosomes displayed intermediate with disomic tendency inheritance or disomic inheritance. For most chromosomes, interspecific recombination was observed in distal areas. It appeared however very limited for LG08 with only $2.4 \%$ of identified interspecific recombined gametes in one of the two chromosome arms.

The genetic mapping reveals effective recombination rates per $\mathrm{Mb}(1.2 \mathrm{cM} / \mathrm{Mb})$ strongly lower when compared with diploid $(3.3 \mathrm{cM} / \mathrm{Mb})$ and tetraploid clementine $(3.4$ $\mathrm{cM} / \mathrm{Mb}$ ). It is, at least in part, a direct consequence of medium to high preferential pairing preventing interspecific chiasmata and thus interspecific recombination. It is also possible that sequence divergence between $C$. medica and $C$. micrantha decrease the recombination frequency when interspecific pairing is effective. Interspecificity is well known to decrease recombination rates (Manrique-Carpintero; 2016). The impact of structural heterozygosity on recombination frequency is variable as discussed by Parker et al. (1982). It is however well established that sequence divergence at the interspecific level has an inhibitory effect on sexual recombination (Chambers et al., 1996; Opperman et al., 2004; Li et al., 2006; Chetelat et al., 2000). For citrus, variations of recombination rates were observed between clementine and sweet orange (Ollitrault et al., 2012b). The authors proposed that this may be related with the higher $C$. reticulata / C. maxima heterozygosity in sweet orange than in clementine. A comparative mapping analysis between diploid and tetraploid 'Mexican' lime would enlighten the relative impacts of preferential pairing at tetraploid level and sequence divergence when interspecific pairing is effective, on effective interspecific recombination during tetraploid 'Mexican' lime meiosis.

Synteny was observed on the diploid clementine, DD clementine and 'Mexican' lime. Collinearity was high between diploid and tetraploid clementine maps, while the alignment of the genetic maps of the tetraploid 'Mexican' lime with the diploid clementine revealed three inversions in LG02, LG04 and LG06. However the low number of observed recombinations and analyzed markers made the liability of these observations questionable (a few genotyping errors can lead to erroneous ordering). Saturate mapping of larger populations should be necessary to be able to associate the inversion concluded from cytogenetic studies (Iwamasa, 1970) and inverted linkage groups. 


\section{Diploid gametes structures of the doubled diploid 'Mexican' lime are compatible with the origin of the triploid $C$. aurantifolia and $C$. latifolia limes}

'Persian','Tahiti' and 'Bears' limes are different varieties classified as C. latifolia, representing a same ideotype, producing big seedless lime fruits. It is believed that they are a group of clones deriving from a same ancestral hybrid (Morton, 1987). 'Tahiti' lime like was introduced into the Mediterranean region through Iran (where it is called 'Persian' lime), while it reached California from 'Tahiti' between 1850 and 1880 and was introduced in Florida by 1883. The genetic origin of 'Tahiti' lime was unclear until a recent publication of Curk et al. (2016). Previous cytoplasmic studies showed that 'Tahiti' lime shared the same cytoplasm than C. limon and C. aurantium (Bayer et al., 2009; Froelicher et al., 2011). Reece and Childs (1962) proposed from morphological trait segregation studies in 'Tahiti' lime seedlings that this variety may result from lime by citron or lemon hybridization but did not recognize the triploid status of 'Tahiti' lime. Another ideotype of triploid lime producing seedy big lime fruits, represented by several cultivars (such as 'Tanepao', 'Coppenrhad', 'Ambilobe' and 'Mothasseb' limes and 'Madagascar' lemon) is cultivated at lower extent. Curk et al. (2016) demonstrated that these varieties, classified as $C$. aurantifolia, are genetically very close and probably derive from a same ancestral hybrid by mutation or epigenetic variations. They share the same cytoplasm than the 'Mexican' lime (Curk et al., 206). From nuclear molecular study, Curk et al. (2016) proposed that the two main types of triploid limes, 'Tahiti' lime type and 'Tanepao' lime type, were interspecific hybrids involving a diploid gamete of $C$. aurantifolia combined respectively with an haploid ovule of $C$. limon and an haploid pollen of $C$. medica. Moreover, their data suggest that the PHRs of the concerned diploid gamete were respectively $88 \%$ and 95\%. Curk et al. (2016) hypothesized that these diploid gametes should be originated from a natural DD of 'Mexican' lime like, such as the 'Giant key' lime selected in a seedling of diploid 'Key' lime (a 'Mexican' lime clone) or should be unreduced gametes from a diploid 'Mexican' lime like variety. The average PHR value (90.2\%) and range (between $65.7 \%$ and $100 \%$ ) observed in the present work for the DD 'Mexican' lime are compatible with the one estimated by Curk et al. (2016) for 'Tahiti' and 'Tanepao' types. At the opposite, secondary division restitution (SDR) described as the main mechanism of unreduced mega-gametophyte production in citrus (Luro et al., 2004; Cuenca et al., 2011; 2015; Aleza et al., 2016a) results on lower value of PHR (40\% in average) (Peloquin, 1983; Hutten et al., 1994; Carputo et al., 2003). Therefore SDR 2n gametes are not compatible with the interspecific genetic structure of 'Tahiti' and 'Tanepao' limes. First division restitution (FDR) identified as the predominant mechanism for diploid pollen formation in a clementine $\mathrm{x}$ sweet orange hybrid (Rouiss et al., 2017a) and secondary mechanisms in lemon $2 \mathrm{n}$ gamete ovule production (Rouiss et al., 2017b) should produce diploid gamete with high PHR (80 \% in average; Peloquin, 1983; Hutten et al., 1994; Carputo et al., 2003) particularly if it is coupled with asynapsis described in diploid 'Mexican' lime (Iwamasa et al., 1966). Indeed FDR associated with strict asynapsis for all chromosomes would result in 100\% of PHR. The study of the mechanisms and structure of unreduced gamete of diploid 'Mexican' lime will be necessary to definitively conclude on the origin of the C. latifolia and C. aurantifolia triploid limes. However the interploid hybridisation hypothesis fits well with the actual molecular data on these two types of triploid limes, the natural occurrence of tetraploid 'Mexican' limes and our present results on the phylogenetic diploid gamete structure produced by the doubled diploid 'Mexican' lime. 


\section{Implications for 'Tahiti ' and 'Tanepao' lime like breeding}

As discussed before, doubled diploid 'Mexican' lime can produce diploid gametes with genetic structure similar to the ones that originated the 'Tahiti' and 'Tanepao' lime types. Therefore this opens the possibility to develop a reconstruction breeding strategy for these limes using a doubled diploid 'Mexican' lime like parent. It should be based on the selection of breeding parents with interesting variations (disease resistance, improved phenology, primary and secondary metabolites contents, etc).

Chromosome doubling of the diploid 'Mexican' lime restored good pollen viability, so it could be used for extensive breeding programs to produce 'Tahiti ' and 'Tanepao' lime like hybrids. It should have much more efficiency than the search for triploid hybrids resulting from unreduced gametes of 'Mexican' limes. Indeed the partial apomixes of parents, limiting strongly hybrid recovery, coupled with the relatively low frequency of 2n gametes described in citrus (Esen and Soost, 1971; Geraci et al., 1977; Cuenca et al., 2016) should be a real impediment for efficient triploid lime breeding from unreduced gametes, as it was developed using non apomictic female parent for mandarin breeding (Ollitrault et al., 2008; Aleza et al., 2010b).

The predominant intermediate segregation with tendency for disomic inheritance observed for the different LGs of the DD 'Mexican' lime results in highly heterozygous gametes. Indeed, about $90 \%$ of the 'Mexican' lime heterozygosity would be transmitted to triploid progenies via diploid gametes. It should avoid inbreeding depression in triploid hybrids that can occur when using doubled diploid parents with tetrasomic inheritance (Gallais, 2003). The lower diversity of diploid gametes produced by such meiotic mechanisms is also favorable to reconstruct phylogenomic structures similar to the two triploid limes ideotypes, optimizing the probability to select new variety phenotypically close to the ideotypes. The development and application of molecular markers diagnosis of the four ancestral taxa of cultivated citrus (Curk et al., 2015) will allow improving the efficiency of such reconstruction breeding strategies.

On the other hand, the limitation of the effective interspecific recombination associated with predominant disomic inheritance, as illustrated by the decrease of the genetic length of the different genetic LGs for the tetraploid 'Mexican' lime, when compared with diploid and teraploid clementine maps, should impact breeding efficiency due to an increased linkage drag. It should require developing large progenies if it is needed to separate a given locus of genetic importance from another linked undesired locus. However, even limited, interspecific recombination has been observed for each chromosome, opening large possibilities for lime breeding considering the high pollen viability of the DD 'Mexican' lime and thus the capacity to generate large triploid progenies. 


\section{Conclusion}

The doubled-diploid 'Mexican' lime had a predominantly disomic segregation. Preferential pairing varies between chromosomes. Disomic inheritance with high preferential pairing values was observed for three LGs (LG02, LG07 and LG08), intermediate segregation with tendency for preferential pairing was found for five LGs (LG01, LG03, LG04, LG06, and LG09) and intermediate segregation for LG05. The cytogenetic observations are compatible with the interspecific $(C$. medica / $C$. micrantha) chromosome pairing and recombination revealed for each LGs by molecular marker study. The disomic tendency limits the effective interspecific recombination and the diversity of the diploid gamete population. The interspecific phylogenetic structures of the produced diploid gametes with high $C$. medica / C. micrantha heterozygosity are compatible with the ones that generate the triploids $C$. latifolia and $C$. aurantifolia varieties that may therefore results from interploid hybridization. The restored pollen fertility of the doubled diploid 'Mexican' lime compared with the diploid and the genetic structures of the diploid gametes fitting with the origin of $C$. aurantifolia and $C$. latifolia triploid limes open the way for efficient reconstruction breeding programs based on interploid hybridization for the diversification of triploid lime germplasm. 


\section{Supplementary information}

Additional table 3.1. Phylogenomic structure of the 'Mexican' lime diploid gametes for the nine LGs

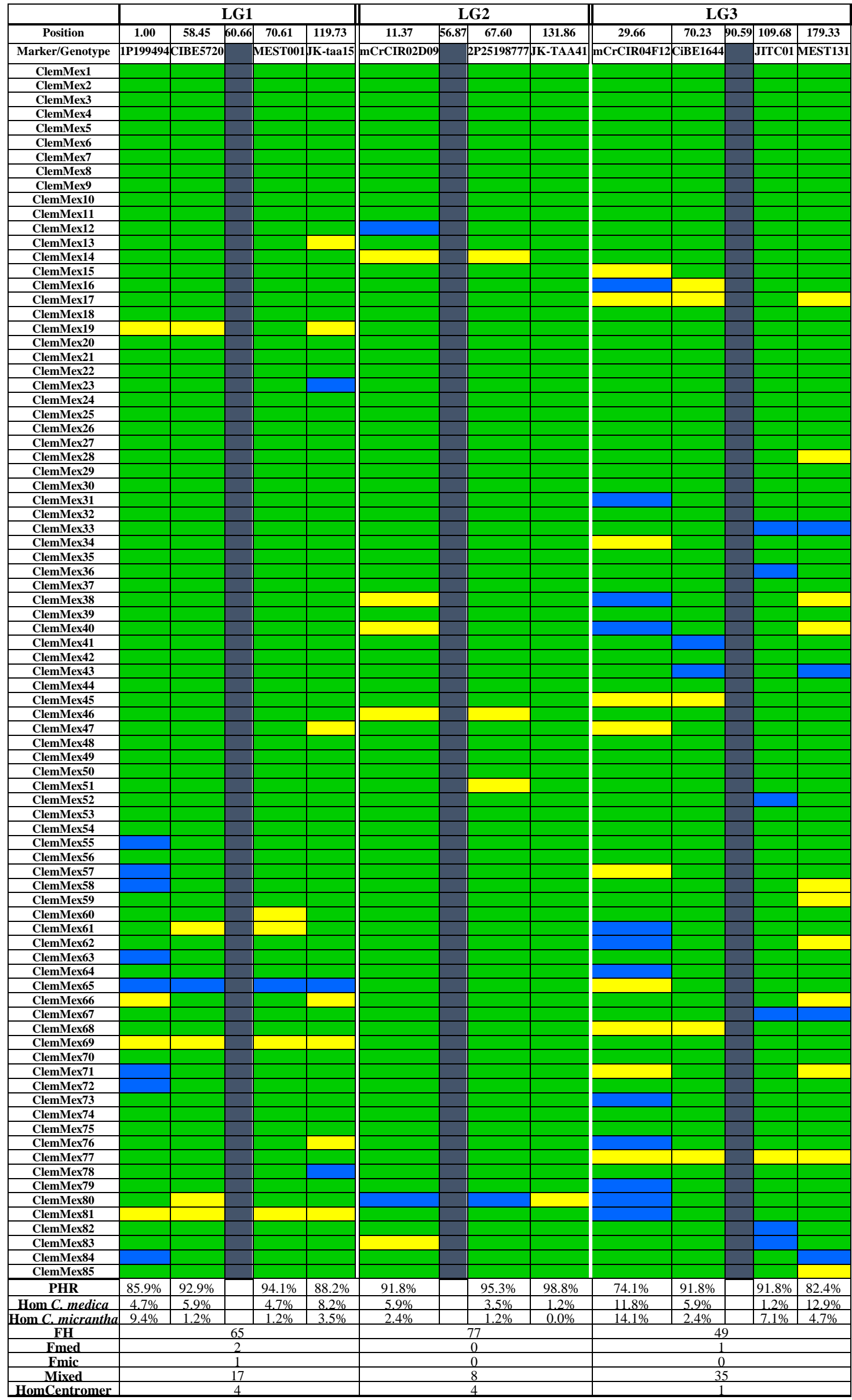


Additional table 3.1. - cont. Phylogenomic structure of the 'Mexican' lime diploid gametes for the nine LGs

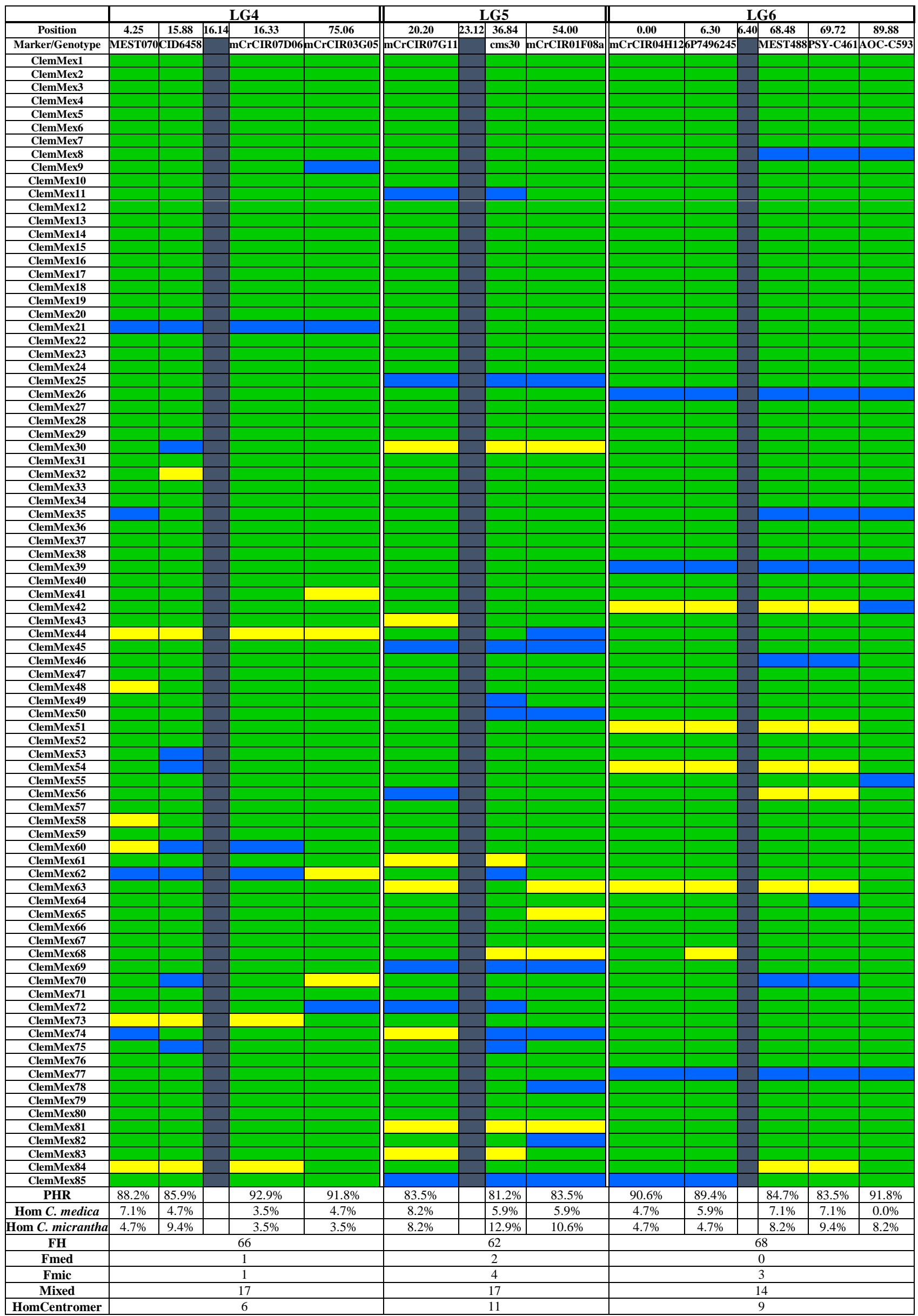


Chapter III

Additional table 3.1. - cont. Phylogenomic structure of the 'Mexican' lime diploid gametes for the nine LGs

\begin{tabular}{|c|c|c|}
\hline & L( & G7 \\
\hline Position & 8.90 & 40.00 \\
\hline Marker & MEST107 & DXS-C54 \\
\hline ClemMex1 & & \\
\hline ClemMex2 & & \\
\hline ClemMex3 & & \\
\hline ClemMex4 & & \\
\hline ClemMex5 & & \\
\hline ClemMex6 & & \\
\hline ClemMex7 & & \\
\hline ClemMex8 & & \\
\hline ClemMex9 & & \\
\hline ClemMex10 & & \\
\hline ClemMex11 & & \\
\hline ClemMex12 & & \\
\hline ClemMex13 & & \\
\hline ClemMex14 & & \\
\hline ClemMex15 & & \\
\hline ClemMex16 & & \\
\hline ClemMex17 & & \\
\hline ClemMex18 & & \\
\hline Clem & & \\
\hline ClemMex20 & & \\
\hline ClemMex21 & & \\
\hline ClemMex22 & & \\
\hline ClemMex23 & & \\
\hline ClemMex24 & & \\
\hline ClemMex25 & & \\
\hline ClemMex26 & & \\
\hline ClemMex27 & & \\
\hline ClemMex28 & & \\
\hline ClemMex29 & & \\
\hline ClemMex30 & & \\
\hline ClemMex31 & & \\
\hline ClemMex32 & & \\
\hline ClemMex33 & & \\
\hline ClemMex34 & & \\
\hline ClemMex35 & & \\
\hline ClemMex36 & & \\
\hline ClemMex37 & & \\
\hline ClemMex38 & & \\
\hline ClemMex39 & & \\
\hline ClemMex40 & & \\
\hline ClemMex41 & & \\
\hline ClemMex42 & & \\
\hline ClemMex43 & & \\
\hline ClemMex44 & & \\
\hline ClemMex45 & & \\
\hline ClemMex46 & & \\
\hline ClemMex47 & & \\
\hline ClemMex48 & & \\
\hline ClemMex49 & & \\
\hline ClemMex50 & & \\
\hline ClemMex51 & & \\
\hline ClemMex52 & & \\
\hline ClemMex53 & & \\
\hline ClemMex54 & & \\
\hline ClemMex55 & & \\
\hline ClemMex56 & & \\
\hline ClemMex57 & & \\
\hline ClemMex58 & & \\
\hline ClemMex59 & & \\
\hline ClemMex60 & & \\
\hline ClemMex61 & & \\
\hline ClemMex62 & & \\
\hline ClemMex63 & & \\
\hline ClemMex64 & & \\
\hline ClemMex65 & & \\
\hline ClemMex66 & & \\
\hline ClemMex67 & & \\
\hline ClemMex68 & & \\
\hline ClemMex69 & & \\
\hline ClemMex70 & & \\
\hline ClemMex71 & & \\
\hline ClemMex72 & & \\
\hline ClemMex73 & & \\
\hline ClemMex74 & & \\
\hline ClemMex75 & & \\
\hline ClemMex76 & & \\
\hline ClemMex77 & & \\
\hline ClemMex78 & & \\
\hline ClemMex79 & & \\
\hline ClemMex80 & & \\
\hline ClemMex81 & & \\
\hline ClemMex82 & & \\
\hline ClemMex83 & & \\
\hline ClemMex84 & & \\
\hline ClemMex85 & & \\
\hline PHR & $85.9 \%$ & $94.1 \%$ \\
\hline Hom C. medica & $9.4 \%$ & $4.7 \%$ \\
\hline Hom C. micrantha & $4.7 \%$ & $1.2 \%$ \\
\hline $\begin{array}{r}\text { FH } \\
\end{array}$ & & \\
\hline Fmed & & \\
\hline Fmic & & \\
\hline Mixed & & \\
\hline HomCentromer & & \\
\hline
\end{tabular}


Chapter III

Additional table 3.1. - cont. Phylogenomic structure of the 'Mexican' lime diploid gametes for the nine LGs

\begin{tabular}{|c|c|c|c|c|c|c|c|c|}
\hline Position & PHR & Hom Med & Hom Mic & FH & Fmed & Fmic & Mixed & HomCentromer \\
\hline ClemMex1 & $100.0 \%$ & $0.0 \%$ & $0.0 \%$ & 9 & 0 & 0 & 0 & 0 \\
\hline ClemMex2 & $100.0 \%$ & $0.0 \%$ & $0.0 \%$ & 9 & 0 & 0 & 0 & 0 \\
\hline ClemMex3 & $100.0 \%$ & $0.0 \%$ & $0.0 \%$ & 9 & 0 & 0 & 0 & 0 \\
\hline ClemMex4 & $100.0 \%$ & $0.0 \%$ & $0.0 \%$ & 9 & 0 & 0 & 0 & 0 \\
\hline ClemMex5 & $100.0 \%$ & $0.0 \%$ & $0.0 \%$ & 9 & 0 & 0 & 0 & 0 \\
\hline ClemMex6 & $100.0 \%$ & $0.0 \%$ & $0.0 \%$ & 9 & 0 & 0 & 0 & 0 \\
\hline ClemMex7 & $85.7 \%$ & $11.4 \%$ & $2.9 \%$ & 8 & 0 & 0 & 1 & 1 \\
\hline ClemMex8 & $91.4 \%$ & $0.0 \%$ & $8.6 \%$ & 8 & 0 & 0 & 1 & 0 \\
\hline ClemMex9 & $97.1 \%$ & $0.0 \%$ & $2.9 \%$ & 8 & 0 & 0 & 1 & 0 \\
\hline ClemMex10 & $97.1 \%$ & $0.0 \%$ & $2.9 \%$ & 8 & 0 & 0 & 1 & 0 \\
\hline ClemMex11 & $94.3 \%$ & $0.0 \%$ & $5.7 \%$ & 8 & 0 & 0 & 1 & 1 \\
\hline ClemMex12 & $97.1 \%$ & $0.0 \%$ & $2.9 \%$ & 8 & 0 & 0 & 1 & 0 \\
\hline ClemMex13 & $97.1 \%$ & $2.9 \%$ & $0.0 \%$ & 8 & 0 & 0 & 1 & 0 \\
\hline ClemMex14 & $94.3 \%$ & $5.7 \%$ & $0.0 \%$ & 8 & 0 & 0 & 1 & 1 \\
\hline ClemMex15 & $97.1 \%$ & $2.9 \%$ & $0.0 \%$ & 8 & 0 & 0 & 1 & 0 \\
\hline ClemMex16 & $94.3 \%$ & $2.9 \%$ & $2.9 \%$ & 8 & 0 & 0 & 1 & 0 \\
\hline ClemMex17 & $91.4 \%$ & $8.6 \%$ & $0.0 \%$ & 8 & 0 & 0 & 1 & 0 \\
\hline ClemMex18 & $97.1 \%$ & $0.0 \%$ & $2.9 \%$ & 8 & 0 & 0 & 1 & 0 \\
\hline ClemMex19 & $91.4 \%$ & $8.6 \%$ & $0.0 \%$ & 8 & 0 & 0 & 1 & 0 \\
\hline ClemMex20 & $97.1 \%$ & $0.0 \%$ & $2.9 \%$ & 8 & 0 & 0 & 1 & 0 \\
\hline ClemMex21 & $88.6 \%$ & $0.0 \%$ & $11.4 \%$ & 8 & 0 & 1 & 0 & 1 \\
\hline ClemMex22 & $97.1 \%$ & $0.0 \%$ & $2.9 \%$ & 8 & 0 & 0 & 1 & 0 \\
\hline ClemMex23 & $97.1 \%$ & $0.0 \%$ & $2.9 \%$ & 8 & 0 & 0 & 1 & 0 \\
\hline ClemMex24 & $91.4 \%$ & $8.6 \%$ & $0.0 \%$ & 8 & 0 & 0 & 1 & 0 \\
\hline ClemMex25 & $91.4 \%$ & $0.0 \%$ & $8.6 \%$ & 8 & 0 & 1 & 0 & 1 \\
\hline ClemMex26 & $85.7 \%$ & $0.0 \%$ & $14.3 \%$ & 8 & 0 & 1 & 0 & 1 \\
\hline ClemMex27 & $97.1 \%$ & $2.9 \%$ & $0.0 \%$ & 8 & 0 & 0 & 1 & 0 \\
\hline ClemMex28 & $97.1 \%$ & $2.9 \%$ & $0.0 \%$ & 8 & 0 & 0 & 1 & 0 \\
\hline ClemMex29 & $97.1 \%$ & $2.9 \%$ & $0.0 \%$ & 8 & 0 & 0 & 1 & 0 \\
\hline ClemMex30 & $88.6 \%$ & $8.6 \%$ & $2.9 \%$ & 7 & 1 & 0 & 1 & 1 \\
\hline ClemMex31 & $94.3 \%$ & $2.9 \%$ & $2.9 \%$ & 7 & 0 & 0 & 2 & 0 \\
\hline ClemMex32 & $91.4 \%$ & $8.6 \%$ & $0.0 \%$ & 7 & 0 & 0 & 2 & 0 \\
\hline ClemMex33 & $91.4 \%$ & $0.0 \%$ & $8.6 \%$ & 7 & 0 & 0 & 2 & 0 \\
\hline ClemMex34 & $94.3 \%$ & $5.7 \%$ & $0.0 \%$ & 7 & 0 & 0 & 2 & 0 \\
\hline ClemMex35 & $88.6 \%$ & $0.0 \%$ & $11.4 \%$ & 7 & 0 & 0 & 2 & 0 \\
\hline ClemMex36 & $94.3 \%$ & $2.9 \%$ & $2.9 \%$ & 7 & 0 & 0 & 2 & 0 \\
\hline ClemMex37 & $94.3 \%$ & $0.0 \%$ & $5.7 \%$ & 7 & 0 & 0 & 2 & 0 \\
\hline ClemMex38 & $91.4 \%$ & $5.7 \%$ & $2.9 \%$ & 7 & 0 & 0 & 2 & 0 \\
\hline $\begin{array}{l}\text { Clemex39 } \\
\end{array}$ & $82.9 \%$ & $0.0 \%$ & $17.1 \%$ & 7 & 0 & 1 & 1 & 1 \\
\hline ClemMex40 & $91.4 \%$ & $5.7 \%$ & $2.9 \%$ & 7 & 0 & 0 & 2 & 0 \\
\hline ClemMex41 & $94.3 \%$ & $2.9 \%$ & $2.9 \%$ & 7 & 0 & 0 & 2 & 0 \\
\hline ClemMex42 & $82.9 \%$ & $14.3 \%$ & $2.9 \%$ & 7 & 0 & 0 & 2 & 1 \\
\hline ClemMex43 & $91.4 \%$ & $2.9 \%$ & $5.7 \%$ & 7 & 0 & 0 & 2 & 0 \\
\hline ClemMex44 & $85.7 \%$ & $11.4 \%$ & $2.9 \%$ & 7 & 1 & 0 & 1 & 1 \\
\hline ClemMex45 & $85.7 \%$ & $5.7 \%$ & $8.6 \%$ & 7 & 0 & 1 & 1 & 1 \\
\hline ClemMex46 & $88.6 \%$ & $5.7 \%$ & $5.7 \%$ & 7 & 0 & 0 & 2 & 1 \\
\hline ClemMex47 & $94.3 \%$ & $5.7 \%$ & $0.0 \%$ & 7 & 0 & 0 & 2 & 0 \\
\hline ClemMex48 & $94.3 \%$ & $2.9 \%$ & $2.9 \%$ & 7 & 0 & 0 & 2 & 0 \\
\hline ClemMex49 & $94.3 \%$ & $0.0 \%$ & $5.7 \%$ & 7 & 0 & 0 & 2 & 0 \\
\hline ClemMex50 & $85.7 \%$ & $8.6 \%$ & $5.7 \%$ & 7 & 0 & 0 & 2 & 0 \\
\hline ClemMex51 & $85.7 \%$ & $14.3 \%$ & $0.0 \%$ & 7 & 0 & 0 & 2 & 2 \\
\hline ClemMex52 & $97.1 \%$ & $0.0 \%$ & $2.9 \%$ & 8 & 0 & 0 & 1 & 0 \\
\hline ClemMex53 & $94.3 \%$ & $0.0 \%$ & $5.7 \%$ & 7 & 0 & 0 & 2 & 0 \\
\hline ClemMex54 & $85.7 \%$ & $11.4 \%$ & $2.9 \%$ & 7 & 0 & 0 & 2 & 1 \\
\hline ClemMex55 & $94.3 \%$ & $0.0 \%$ & $5.7 \%$ & 7 & 0 & 0 & 2 & 0 \\
\hline ClemMex56 & $91.4 \%$ & $5.7 \%$ & $2.9 \%$ & 7 & 0 & 0 & 2 & 0 \\
\hline ClemMex57 & $94.3 \%$ & $2.9 \%$ & $2.9 \%$ & 7 & 0 & 0 & 2 & 0 \\
\hline ClemMex58 & $91.4 \%$ & $5.7 \%$ & $2.9 \%$ & 6 & 0 & 0 & 3 & 0 \\
\hline ClemMex59 & $91.4 \%$ & $2.9 \%$ & $5.7 \%$ & 6 & 0 & 0 & 3 & 0 \\
\hline ClemMex60 & $85.7 \%$ & $5.7 \%$ & $8.6 \%$ & 6 & 0 & 0 & 3 & 1 \\
\hline ClemMex61 & $85.7 \%$ & $11.4 \%$ & $2.9 \%$ & 6 & 0 & 0 & 3 & 2 \\
\hline ClemMex62 & $80.0 \%$ & $5.7 \%$ & $14.3 \%$ & 6 & 0 & 0 & 3 & 1 \\
\hline ClemMex63 & $80.0 \%$ & $17.1 \%$ & $2.9 \%$ & 6 & 0 & 0 & 3 & 1 \\
\hline ClemMex64 & $91.4 \%$ & $0.0 \%$ & $8.6 \%$ & 6 & 0 & 0 & 3 & 0 \\
\hline ClemMex65 & $82.9 \%$ & $5.7 \%$ & $11.4 \%$ & 6 & 0 & 1 & 2 & 1 \\
\hline ClemMex66 & $88.6 \%$ & $8.6 \%$ & $2.9 \%$ & 6 & 0 & 0 & 3 & 0 \\
\hline ClemMex67 & $88.6 \%$ & $2.9 \%$ & $8.6 \%$ & 6 & 0 & 0 & 3 & 0 \\
\hline ClemMex68 & $85.7 \%$ & $14.3 \%$ & $0.0 \%$ & 6 & 0 & 0 & 3 & 1 \\
\hline ClemMex69 & $77.1 \%$ & $14.3 \%$ & $8.6 \%$ & 6 & 1 & 1 & 1 & 2 \\
\hline ClemMex70 & $85.7 \%$ & $5.7 \%$ & $8.6 \%$ & 6 & 0 & 0 & 3 & 0 \\
\hline ClemMex71 & $88.6 \%$ & $8.6 \%$ & $2.9 \%$ & 6 & 0 & 0 & 3 & 0 \\
\hline ClemMex72 & $88.6 \%$ & $0.0 \%$ & $11.4 \%$ & 6 & 0 & 0 & 3 & 1 \\
\hline $\begin{array}{l}\text { Clem } M \text { 73 } \\
\end{array}$ & $85.7 \%$ & $8.6 \%$ & $5.7 \%$ & 6 & 0 & 0 & 3 & 1 \\
\hline ClemMex 74 & $85.7 \%$ & $2.9 \%$ & $11.4 \%$ & 6 & 0 & 0 & 3 & 2 \\
\hline ClemMex75 & $91.4 \%$ & $2.9 \%$ & $5.7 \%$ & 6 & 0 & 0 & 3 & 0 \\
\hline ClemMex76 & $91.4 \%$ & $2.9 \%$ & $5.7 \%$ & 6 & 0 & 0 & 3 & 0 \\
\hline ClemMex77 & $71.4 \%$ & $11.4 \%$ & $17.1 \%$ & 6 & 1 & 1 & 1 & 2 \\
\hline ClemMex78 & $91.4 \%$ & $0.0 \%$ & $8.6 \%$ & 6 & 0 & 0 & 3 & 0 \\
\hline ClemMex79 & $88.6 \%$ & $5.7 \%$ & $5.7 \%$ & 6 & 0 & 0 & 3 & 0 \\
\hline ClemMex80 & $82.9 \%$ & $8.6 \%$ & $8.6 \%$ & 5 & 0 & 0 & 4 & 1 \\
\hline ClemMex81 & $74.3 \%$ & $20.0 \%$ & $5.7 \%$ & 5 & 2 & 0 & 2 & 2 \\
\hline ClemMex82 & $80.0 \%$ & $11.4 \%$ & $8.6 \%$ & 5 & 0 & 0 & 4 & 1 \\
\hline ClemMex83 & $77.1 \%$ & $20.0 \%$ & $2.9 \%$ & 5 & 0 & 0 & 4 & 2 \\
\hline ClemMex84 & $77.1 \%$ & $17.1 \%$ & $5.7 \%$ & 4 & 0 & 0 & 5 & 1 \\
\hline ClemMex85 & $65.7 \%$ & $20.0 \%$ & $14.3 \%$ & 4 & 0 & 1 & 4 & 3 \\
\hline & rspecif & osity (C & tha X C. & ica) & & & & \\
\hline & cranth & gosity & & & & & & \\
\hline & dica $\mathrm{b}$ & ity & & & & & & \\
\hline & romer & & & & & & & \\
\hline
\end{tabular}

FH: percentage of fully heterozygous gametes for the LG; Fmed: fully C. medica homozygous gametes for the LG; Fmic: fully C. micrantha homozygous gametes for the LG; Mixed: gametes with mixed heterozygosity and homozygosity for the LG. HomCentromer: gametes with fully homozygous centromere 


\section{General discussion}





\section{Background}

Polyploidy represents a major evolutionary step toward speciation and diversification (Grant, 1981; Soltis et al., 1993; Otto and Whitton, 2000; Wendel and Doyle, 2005). Its origin, evolutionary significance and interest for breeding programs are still under study and discussion (Bretagnolle and Thompson, 1995; Ortiz, 1997; Ramsey and Schemske, 1998; Otto and Whitton, 2000; Gallais, 2003; Ollitrault et al., 2008).

Sexual polyploidization through unreduced gametes ( $2 \mathrm{n}$ gametes) is considered as the major mechanism leading to polyploidy (Harlan and deWet, 1975; Bretagnolle and Thompson, 1995; Ramsey and Schemske, 1998). Up to seven major mechanisms of 2n gamete formation have been characterized. However, De Storme and Geelen (2013a) reduced them in two major mechanisms: genomic duplication and meiotic restitution. For the genomic doubling, we can distinguish two variants depending when it occurs. If it is before the meiosis, it is called the pre-meiotic doubling (PRD), and it was observed in Solanum lycopersicum (De Storme and Geelen, 2013b). Otherwise, if the meiosis precedes the doubling, it is called the post-meiotic restitution (PMD), characterized by the formation of fully homozygous $2 \mathrm{n}$ gametes. This was observed in $S$. tuberosum (Bastiaanssen et al., 1998), in some Rubus species (Dowrick, 1966), and in Alstroemeria (Ramanna and Jacobsen, 2003). For the meiotic restitution, two main mechanisms have been widely described: first-division restitution (FDR) and seconddivision restitution (SDR). They occur, respectively, as a result of an abnormal development of the first and second meiotic division. FDR have been observed in potato, alfalfa, Vaccinium spp. and some of grasses (Ramanna and Jacobsen, 2003).

These different mechanisms result in very different genetic structures of the $2 n$ gamete populations. PRD produces $2 \mathrm{n}$ gametes equivalent to the meiosis of doubled diploid (DD) genotypes. Therefore, PHR depends mainly on the chromosomal preferential pairing rate and varies between $66 \%$ for fully tetrasomic meiosis to $100 \%$ for fully disomic meiosis (Stift et al., 2008). For PMD, the duplication affects the haploid gametes, leading to the formation of fully homozygous $2 \mathrm{n}$ gametes. Thus, $100 \%$ homozygosity for all LGs is expected among the 2n gametes (Ramanna and Jacobsen, 2003). FDR 2n gametes contain non-sister chromatids, which in the absence of crossover maintain the parental heterozygosity. For SDR, the $2 \mathrm{n}$ gametes contain two sister chromatids, which reduces the parental heterozygosity level (Cuenca et al., 2011; De Storme and Geelen, 2013a). When crossover occurs, the parental heterozygosity restitution (PHR) rate for FDR varies from $100 \%$ for loci close to the centromere to 60 $70 \%$ for loci far from the centromere. For SDR, it varies from $0 \%$ for loci close to the centromere to $60-75 \%$ for loci far from the centromere depending on the level of chromosome interference (Cuenca et al., 2011).

Citrus species produce a, relatively, high percentage of unreduced ovules, reaching $20 \%$ in some genotypes (Ollitrault et al., 2008; Aleza et al., 2010b; Cuenca et al., 2011). Before undertaking the present study, only FDR and SDR had been reported in citrus, being SDR the main mechanism of $2 \mathrm{n}$ megaspore formation in mandarins (Esen et al., 1979; Luro et al., 2000; Cuenca et al., 2011; 2015; Aleza et al., 2016a). Not really conclusive results were published for other citrus species due to insufficient numbers of individuals or markers under analysis. Although there is no reason to discard the possibilities to observe/interpret other mechanisms resulting in unreduced gametes in citrus mainly the PMD and PRD mechanisms described in other species. 
Harlan and deWet (1975) argued that chromosome doubling of somatic cells must be relatively rare in nature compared to the occurrence of unreduced gametes. If it affects only some cells of a meristem it should result in ploidy chimeras or cytochimeras (Zonneveld, 2007). However, Citrus is an interesting example were chromosome doubling appears to be frequent in nucellar cells and results in non-chimeric doubleddiploid genotypes (Aleza et al., 2012a, b; Guerra et al., 2016) in polyembryonic citrus (facultative apomixes). It also was observed in apomictic mangos (Saúco et al., 2001). Curiously, despite this relatively high rate of chromosome doubling most of the natural citrus germplasm is diploid (Ollitrault et al., 2008). Several breeding programs over the word (Florida, Brazil, Italy, Spain, France, etc...) have taken advantage of this mechanism to diversify the citrus tetraploid gene pool. Recently, chemical treatments with colchicine and oryzalin were used to obtain double-diploid of mono-embryonic varieties such as clementine or Fortune mandarin (Aleza et al., 2009b). Therefore, this new citrus tetraploid gene pool is mostly constituted by natural and induced doubleddiploid accessions, but also include somatic hybrids (Grosser et al., 2000; Dambier et al., 2011) and a few sexual tetraploid hybrids.

The inheritance of tetraploids can be schematically considered around two extreme models, disomic and tetrasomic (Gallais, 2003; Stift et al., 2008; Jeridi et al., 2012). Tetrasomic inheritance is observed in autotetraploids, where each chromosome has three other homologous copies and has equal opportunity to pair with other homologs, leading to multivalent formation and random pairing of chromosomes. At the opposite, allotetraploids resulting from the merging of two different genomes, display disomic inheritance; each chromosome has only one homolog to pair, resulting in strictly preferential pairing during meiosis (Sybenga, 2012). However, the meiotic inheritance in tetraploids may be affected by the chromosomes pairing affinity (Sybenga, 1996). Both bivalent and multivalent pairing behavior can be observed simultaneously (Wu et al., 2001), which may result in an intermediate chromosome pairing between strictly preferential and non-preferential pairing and intermediate segregation (Stift et al., 2008). Strict disomic inheritance results in the complete restitution of the interspecific heterozygosity. In the case of allotetraploids each diploid gamete is the equivalent of the parental interspecific diploid hybrid $(\mathrm{PHR}=100 \%)$. For autotetraploids with no double reduction, the expected percentage is $\mathrm{PHR}=66 \%$. Intermediate pairing results in PHR between these two values.

Cytological techniques, especially genomic in situ hybridization-GISH or/and fluorescent in situ hybridization-FISH (Lim et al., 2001; Crespel and Gudin, 2003; Dewitte et al., 2012; Jeridi et al., 2012; Silkova and Loginova, 2016) have been used to analyze the origin of $2 \mathrm{n}$ gametes and the meiosis of tetraploids. For unreduced gametes, half tetrad analysis approaches (Mendiburu and Peloquin, 1979) with a predefined order of markers (Tavoletti et al., 1996) or without any previous information about marker position (Da et al., 1995) have been developed and applied in different species. These approaches required working at population level with numerous markers. More recently, Cuenca et al. (2015) proposed a maximum likelihood method based on PHR of centromeric markers to differentiate between FDR and SDR mechanisms at individual and population level. It was successfully applied to Citrus, taking advantage of the centromeres location (Aleza et al., 2015) in the reference genetic map (Ollitrault et al., 2012a). Although this method allows comparing a large range of partial interference 
model functions (Cuenca et al., 2015), its limitation is that it does not take in consideration other mechanisms of $2 \mathrm{n}$ gamete formation, such as PRD or PMD.

Ploidy manipulation is an integrated component of several citrus breeding projects around the world. It is applied with two main objectives: (i) the development of triploid seedless cultivars mainly in the mandarin group, and to a lesser extend in the acid citrus group (limes, lemons) and (ii) the creation of new tetraploid rootstocks with a better adaptation to biotic and abiotic stresses. Spontaneous unreduced gametes have been widely exploited for triploid citrus breeding from diploid $\mathrm{x}$ diploid crosses (Esen and Soost, 1971; 1973a; Ollitrault et al., 2008; Aleza et al., 2010b; Cuenca et al., 2015; Navarro et al., 2015) and the development of the tetraploid gene-pool also allowed to produce triploid hybrids by interploid crosses 2x x 4x and 4x x 2x (Esen and Soost, 1973b; Cameron and Burnett, 1978; Starrantino and Recupero, 1981; Ollitrault et al., 2008; Grosser and Gmitter, 2011; Aleza et al., 2012a, b; Navarro et al., 2015). Most tetraploid parents are doubled-diploids, but also allotetraploid parents are used). Sexual hybridization at tetraploid level is a relatively recent strategy for rootstock breeding. The so called tetrazyg breeding strategy was initiated in Florida (Grosser et al., 2003) and it is also developed in France (Ollitrault Pers. Com.) and Italy (Caruso Pers. Com.). For tetrazyg rootstock development, the parents are either somatic hybrids or DD of interspecific or intergeneric origins. A clear understanding of the meiotic mechanisms producing the diploid gametes (unreduced from diploid parents and reduced from tetraploid parents) and their implication in the genetic structures of gamete populations is fundamental to optimize the breeding strategies based on ploidy manipulation in citrus.

In this thesis, we have extended the knowledge on the formation of unreduced gametes to the male gametophyte by the analysis of the genetic structure of diploid pollen population produced by the diploid 'CSO' tangor, inferred from tetraploid hybrids in tetraploid x diploid 'CSO' cross and to the megagametophytes of $C$. limon species based on the inference of the diploid ovules of 'Eureka Frost' and 'Fino' lemons from triploid and tetraploid progenies arising respectively from diploid $\mathrm{x}$ diploid and diploid $x$ tetraploid crosses. We have also analyzed the meiotic behavior of a DD 'Mexican' lime to evaluate the possibility that triploid 'Tahiti' $(C$. latifolia) and 'Tanepao' $(C$. aurantifolia) limes were originated by interploid hybridization involving a DD 'Mexican' lime. The results are discussed with the perspective of triploid mandarin and acid citrus breeding.

\section{The predominant mechanisms of $2 \mathrm{n}$ gamete formation is SDR for megagametophytes and FDR for pollen}

The frequency of $2 \mathrm{n}$ megagametophytes, for 'Fino' and 'Eureka Frost' lemons were $4.9 \%$ and $8.3 \%$ respectively. These frequencies are in agreement with $1 \%$ to $5 \%$ reported by Geraci et al. (1975) for 'Lisbon' and 'Eureka Frost' lemons respectively. More variable range were observed in mandarins, (1\% to 20\%) for clementines, 'Sukega' and 'Ortanique' tangor (Ollitrault et al., 2008; Aleza et al., 2010b; Wakana et al., 1982; Esen and Soost, 1971; Xie et al., 2014).

The frequency of $2 \mathrm{n}$ gametes that we obtained, confirm the genotype effect for unreduced gamete frequencies. This was observed in citrus and in other herbaceous and woody plants such as Brassica, potato, and peach (Dermen, 1938; Mok and Peloquin, 
1975; Parrott and Smith, 1986; Ollitrault et al., 2008; Aleza et al., 2010b; Mason et al., 2011; Younis et al., 2014) either in unreduced pollen or ovule gametes (Harlan and deWet, 1975; Bretagnolle and Thompson, 1995; Ramsey and Schemske, 1998; Otto and Whitton, 2000). This information could be used for the genetic improvement of unreduced gamete rates, as already attained for Trifolium (frequencies increased from $0.04 \%$ to $47 \%$ ) and Medicago sativa (from $9 \%$ to $78 \%$ ) in only three generations of recurrent selection (Gallais, 2003).

The $4 \mathrm{x} \times 2 \mathrm{x}$ and $2 \mathrm{x} \times 4 \mathrm{x}$ crosses of our studies were favorable to reveal $2 \mathrm{n}$ pollen and egg gamete occurrences. Indeed the embryo/endosperm ploidy ratio $4 / 6(=2 / 3)$ is equivalent to the one produced in $2 \mathrm{x} \times 2 \mathrm{x}$ hybridization with reduced male and female gametes, allowing a normal development of the seeds (Esen and Soost, 1971)(the ratio is different in the two types of crosses).

We analyzed the genetic structures of the inferred unreduced gametes of 'CSO' tangor and 'Eureka Frost' and 'Fino' lemons, using the maximum-likelihood method based on parental heterozygosity restitution (PHR) of centromeric loci and the PHR pattern for one linkage group. Our results showed that FDR is the predominant mechanism producing unreduced pollen for ' $\mathrm{CSO}^{\prime}$ ', while SDR is the main mechanism that produces $2 \mathrm{n}$ ovules in 'Eureka Frost' and 'Fino' lemons. However, we also found that $18.8 \%$ of $2 \mathrm{n}$ ' $\mathrm{CSO}^{\prime}$ pollen arisen from SDR and 7\% of $2 \mathrm{n}$ megagametophytes of 'Eureka frost' and 'Fino' lemons arisen from (FDR) or (PRD). Honsho et al. (2016) also concluded for the occurrence of FDR unreduced pollen from a molecular marker study performed at individual pollen grain level. However no plant resulting from such FDR pollen where described prior our work. SDR was previously proved to be the main restitution mechanism for female gametes in mandarins (Esen et al., 1979; Luro et al., 2000; Cuenca et al., 2011; 2015; Aleza et al., 2015). We demonstrated that it is also the main mechanism in two lemon cultivars. We also revealed the simultaneous occurrence of FDR and SDR unreduced gametes both in 'CSO' pollen and lemons gametophytes. Such observation was previously made in other plant species and particularly potatoes (Conicella et al., 1991) and the predominance of SDR for 2n megagametophytes and FDR for pollen was also described for other plants (Bretagnolle and Thompson, 1995; d'Erfurth et al., 2008).

The combination of the analysis of the PHR pattern in one LG and the maximumlikelihood method based on centromeric markers revealed a new mechanisms of $2 \mathrm{n}$ gamete formation in citrus: the post meiotic chromosome doubling

At methodological level, we demonstrated the complementarity between the analysis of PHR pattern in one LG and the maximum-likelihood method proposed by Cuenca et al. (2015) at individual level. Indeed, considering only centromeric loci, the PMD can lead to the same homozygous patterns than SDR. Therefore the analysis of heterozygosity restitution pattern along LGs at individual level is a useful approach to distinguish between SDR and PMD. Indeed, under PMD, heterozygosity restitution is zero for all markers in all LGs, while heterozygosity may be found for telomeric loci for SDR. The analysis of PHR pattern at population level is also useful to distinguish between SDR and PRD when individual LODs are under the threshold for conclusive results. With enough individuals, it should also be applied to distinguish between FDR and PRD. With FDR-2n gametes, heterozygosity restitution vary from $100 \%$ in centromeric loci to close to $66 \%$ in telomeric areas under non-interference model (Cuenca et al., 2011), 
whereas with pre-meiotic doubling, heterozygosity restitution is expected to be very constant along all the chromosome. Coupling the two approaches, we have revealed for the first time in citrus the occurrence of post-meiotic genome doubling (PMD) in lemons, originating $5 \%$ of the unreduced ovules and therefore the coexistence of at least three mechanisms producing unreduced ovules in lemons.

\section{Doubled diploid `Mexican’ lime display preferential disomic segregation}

In previous studies to evaluate the paring model and the meiotic behavior of a given citrus tetraploid genotype, two methodologies has been used individually or combined: cytogenetic observation through chromosome-squashing techniques (Kamiri et al., 2011; Xie et al., 2015) or/and molecular markers analysis (Kamiri et al., 2011; Xie et al., 2015; Aleza et al., 2016a) to estimate preferential paring from the PHR values in different LGs. To analyze the meiotic behavior of 'Mexican' lime diploid gametes, we produced a populations of 85 tetraploid hybrids between a DD clementine and a DD 'Mexican' lime. We combined pollen viability evaluation, cytogenetic study and segregation analysis of 35 SSR and SNPs markers. The last analysis also allowed evaluating the interspecific recombination rates and comparing them with diploid and tetraploid Clementine. The predominance of bivalents (65\%) in the meiosis of the tetraploid 'Mexican' lime is similar to the observations made in several allotetraploid somatic hybrids (Del Bosco et al., 1999; Chen et al., 2004; Kamiri et al., 2011; Xie et $a l ., 2015)$. Moreover, we observed that $6.3 \%$ of the chromosomes were involved in closed tetravalents. At diploid level, closed tetravalents are usually considered as an evidence for the presence of heterozygous reciprocal translocation (Sybenga, 1975). However there is no indication for such structure in the diploid 'Mexican' lime while typical figures for inversion were observed (Iwamasa and Nito, 1988). A reconciliation between diploid and doubled diploid microsporogenesis cytogenetic observations showed the presence of a double inversion affecting the two arms of a same chromosome. This double inversion pattern may results from chromosome structural variation between $C$. medica and $C$. micrantha, the two parents of the diploid 'Mexican' lime (Nicolosi et al., 2000; Curk et al., 2016). The average PHR value (90.2\%) reported in this work is higher than the ones observed by Kamiri et al. (2011), Xie et al. (2015) and Aleza et al. (2016a). Disomic inheritance with high preferential pairing values was deduced for three LGs (LG2, LG7 and LG8). Intermediate inheritance with disomic tendency was found for five LGs (LG1, LG3, LG4, LG6, and LG9) and intermediate models for LG5. Tetrasomic inheritance was not observed for any chromosome, suggesting that chromosome pairing was affected by a global differentiation rather than discrete and local large structural variations, as the inversion described in diploid 'Mexican' lime. This high preferential pairing could explain the low recombination rates per $\mathrm{Mb}(1.2 \mathrm{cM} / \mathrm{Mb})$, three times lower than in diploid and tetraploid Clementine due to the impediment of the interspecific recombination.

\section{The meiotic behaviour of the DD 'Mexican' lime is compatible with interploid crosses as origin of $C$. latifolia and $C$. aurantifolia triploid limes}

Curk et al. (2016) proposed that the triploid C. latifolia (Tahiti type) and C. aurantifolia ('Tanepao' type) triploid limes, arisen respectively from a diploid gamete of $C$. aurantifolia ('Mexican' lime type) pollinating an ovule of lemon or pollinated by a haploid pollen of citron. For both triploid lime types, considering a 'Mexican' lime diploid and DD parent, the PHR of the gametes involved in the origin of these two lime 
types was evaluated to be between $88 \%$ and $95 \%$. The same authors proposed two alternative hypotheses for the origin of this diploid gamete: (i) a diploid gamete originated from natural DD of 'Mexican' like lime, such as the 'Giant key' or (ii) an unreduced gamete from a diploid 'Mexican' lime like variety. The average PHR rate we observed for the DD 'Mexican' lime (90.2\%) and the natural occurrence of DD 'Mexican' limes make the interploid hybridisation hypothesis compatible with the origin of 'Tahiti' and 'Tanepao' types. An SDR unreduced gamete hypothesis is not compatible with the PHR values estimated by Curk et al. (2016). An FDR unreduced gamete hypothesis could not be discarded. FDR gametes transmit in average $80 \%$ of the parental heterozygosity (Peloquin, 1983; Hutten et al., 1994; Carputo et al., 2003), lower than the one estimated by Curk et al. (2016). However when coupled with asynapsis, described in diploid 'Mexican' lime (Iwamasa and Iwasaki, 1963), it could reach $100 \%$. The analysis of the genetic structures of unreduced gametes of 'Mexican' lime is still necessary to definitively conclude on the origin of the natural C. latifolia and $C$. aurantifolia triploid limes.

\section{Implications for citrus breeding}

For breeding programs based on ploidy manipulation aiming the production of triploid or tetraploid hybrids, the determination of mechanisms underlying $2 \mathrm{n}$ pollen formation is a key information to model the genetic structure of triploid progenies, to develop association studies in polyploid progenies and to optimize breeding strategies. Several previous publications discussed the relative advantages of SDR and FDR gametes in polyploid breeding (Mendiburu and Peloquin, 1977a, b; Hutten et al., 1994; Aleza et al., 2015). If the objective is to create progenies more similar to the parent producing the unreduced gamete, FDR and PRD $-2 n$ gametes will be a better strategy because the resulting $2 \mathrm{n}$ gametes will be heterozygous as their parent from the centromere to the first crossing over in case of FDR and highly heterozygous for all the LGs in the case of PRD (heterozygosity values depending on the pairing model). At the opposite, SDR-2n gametes provide the opportunity to create a larger number of new multilocus genotypic combinations and a higher number of polymorphic progenies, providing new products to meet commercial market segmentation strategies (Cuenca et al., 2011; Aleza et al., 2016a). The PMD mechanism leads to the formation of fully homozygous gametes (Bastiaanssen et al., 1998). Therefore, this mechanism generally promotes inbreeding in the produced hybrids (Tai, 1986; Gallais, 2003).

In addition, the mechanism that generates the $2 \mathrm{n}$ gametes, in relation with the genetic distance to the centromeres of the major genes controlling a selected trait, affects the breeding efficiency. For instance, Cuenca et al. (2013b; 2016) showed that, the Alternaria brown-spot fungal disease was controlled as a recessive trait by a single locus located at $10.5 \mathrm{cM}$ from the centromere of chromosome III. Therefore in crosses between a heterozygous parent producing diploid gametes and a resistant genotype, PMD is the most favorable mechanisms (50\% of resistant hybrids) followed by SDR mechanisms $(40 \%)$. Under FDR mechanism only $5 \%$ of the hybrids will be resistant. For diploid gametes produced by a DD genotype or resulting of PRD the rates of resistant hybrids should vary from $16 \%$ (tetrasomic segregation) to $0 \%$ (disomic segregation) according to the preferential pairing behavior. For major breeding traits, such Alternaria resistance, this knowledge will strongly drive the choice of the polyploid breeding strategy. 
The coexistence of several mechanism of unreduced gamete production in a same genotype and the observed differences for the predominant mechanism between unreduced pollen (FDR) and ovules (SDR) open the way to develop oriented triploid breeding strategies in mandarin types and lemons. It is also the opportunity to develop progenies with increased phenotypic diversity. The tetraploid plants obtained in $4 \mathrm{x} \times 2 \mathrm{x}$ and $2 \mathrm{x} \times 4 \mathrm{x}$ hybridizations for 'CSO' and the 'Eureka frost' and 'Fino' lemon will be integrated in the IVIA tetraploid germplasm. They may be used as parents for further triploid breeding. The plants arising from FDR should be more interesting to provide increased gametic diversity and heterosis in the triploid progenies due to their higher level of heterozygosity, particularly in centromeric regions.

Our work also enlighten the possibility to develop a reconstruction breeding program of the two main ideotypes of triploid limes ('Tahiti' and 'Tanepao' types) by an interploid breeding strategy using a DD 'Mexican' lime. Although the disomic tendency of this DD genotype limits the effective interspecific recombination and the diversity of the diploid gamete population, the restored pollen fertility of the doubled diploid 'Mexican' lime and the consistency of the diploid gametes genetic structures with the ones that originated 'Tahiti' and 'Tanepao' limes open the way for intensive and efficient breeding programs. 


\section{Perspectives}

Our results confirm that the Citrus genus is an interesting model for tetraploid meiosis and unreduced gamete mechanism studies and polyploid research (Ollitrault et al., 2008; Cuenca et al., 2015; Aleza et al., 2009b; 2016a). The associated development of molecular, genetic, and cytogenetic techniques will lead to rapid advancements in the field in coming years.

We have extended to lemon the demonstration that SDR is the main mechanisms of $2 n$ ovule formation and demonstrated that FDR was predominant for a tangor $2 \mathrm{n}$ pollen. Further studies on other ancestral and secondary species, such as citron, pummelo, grapefruit, sweet orange, and lime could determine whether the mechanisms found in mandarin, tangor and lemons are representative for the whole Citrus genus. Moreover, further studies on environment influence and genetic control of unreduced gamete formation would pave the way for improved frequencies of $2 \mathrm{n}$ gametes in triploid breeding programs.

Predominant disomic inheritance was found for a DD 'Mexican' lime, while previous studies of tetraploid citrus (several somatic hybrids and DD clementine) concluded for tetrasomic and intermediate predominance. The meiotic behavior of DDs of citrus secondary species and direct interspecific hybrids between the ancestral taxa will provide information about the genomic differentiation between the basic taxa and its implication in the recombination and segregation of genome fragments. It will be a key to develop further QTLs analysis in polyploid progenies involving tetraploid interspecific parents. Accurate QTL analysis on polyploid progenies will require the development of genotyping methods coupling a pangenomic coverage and the ability for allele doses estimation. Methods based on next-generation sequencing such as Genotyping-by-sequencing (GBS) are promising.

Already developed and future knowledge on the origin and genetics of diploid gametes will strongly improve the efficiency of citrus polyploidy breeding and will result in an increasing position of triploid varieties and tetraploid rootstock in the citrus industry worldwide. 


\section{Conclusions}



First Division Restitution (FDR) and Second Division Restitution (SDR) mechanisms are involved in the unreduced pollen gametes formation

Tetraploid plants arising from crosses between tetraploid clementine as female parent and 'CSO' tangor as male parent were analyzed with molecular markers (SSRs and SNPs). The results showed that the obtained hybrids resulted from unreduced $2 \mathrm{n}$ pollen. The Maximum likelihood method based on PHR of centromeric loci and analysis of PHR patterns along LG2 were used at individual and population levels to determine whether FDR or/and SDR was the mechanism underlying the production of unreduced gametes.

FDR was the conclusive mechanism for $64.1 \%$ of the analyzed plants and SDR for $18.8 \%$. No conclusive results were found for the remaining plants. For citrus, it is the first report of tetraploid progenies obtained from unreduced pollen and the first observation of SDR and FDR leading, in a same genotype, to unreduced microsporogenesis.

\section{Coexistence of different mechanisms of unreduced ovule gametes in lemon}

Unreduced ovule gamete production was evidenced by SSR and SNP markers analysis in two lemon genotypes 'Eureka Frost' and 'Fino' at frequencies of $4.9 \%$ and $8.3 \%$ respectively. Individual and population LOD analysis of centromeric loci, telomeric loci genotyping, and the analysis of PHR patterns along LG1 allowed us to determine three different meiotic mechanisms for formation of $2 \mathrm{n}$ female gametes in lemon, $88 \%$ arised from SDR, 7\% from FDR or PRD, and 5\% from PMD.

This is the first recovery of large lemon progenies through unreduced $2 \mathrm{n}$ gametes and the first identification of a new mechanism, PMD that has never been observed previously in citrus.

PHR pattern in one LG is an essential complementary analysis to the maximumlikelihood method to detect the unreduced gametes mechanisms

The analysis of PHR pattern in one LG helped to distinguish between PMD and SDR mechanisms and between FDR and PRD mechanisms at population level. Therefore the analysis of heterozygosity restitution pattern along LGs is an essential approach to detect the mechanism producing unreduced gametes.

Doubled diploid 'Mexican' lime display preferential disomic segregation, and could be useful for triploid lime breeding programs

The molecular marker analysis of a population of tetraploid hybrids obtained from a doubled diploid (DD) clementine x DD 'Mexican' lime cross proved that DD 'Mexican' lime has a predominantly disomic segregation producing interspecific diploid gamete structures with high $C$. medica/C. micrantha heterozygosity. This disomic tendency limits the recombination and the diversity of the diploid gamete population. However, the relatively high pollen viability compared with the diploid 'Mexican' lime parent is an advantage to develop efficient triploid lime breeding programs.

The meiotic behavior of the doubled-diploid 'Mexican' lime is compatible with interploid crosses as origin of $\boldsymbol{C}$. latifolia and $\boldsymbol{C}$. aurantifolia triploid limes

The high level of PHR observed for the diploid pollen of 'Mexican' lime is compatible with the phylogenomic structures of triploids $C$. latifolia and $C$. aurantifolia varieties. This conclusion could support the hypothesis of the interploid cross (diploid by tetraploid) origin of both triploid varieties. 


\section{$\underline{\underline{\text { Literature cited }}}$}



- Ahmad R, Struss D, Southwick SM. 2003. Development and characterization of microsatellite markers in Citrus. Journal of the American Society for Horticultural Science 128 (4): 584-590.

- Albertin W, Marullo P. 2012. Polyploidy in fungi: evolution after wholegenome duplication. Proceedings of the Royal Society 279: 2497-2509.

- Afek U, Sztejnberg A. 1993. Temperature and gamma irradiation effects on scoparone, a citrus phytoalexin conferring resistance to Phytophthora citrophthora. Phytopathology 83: 753-758.

- Akimitsu K, Peever TL, Timmer LW. 2003. Molecular, ecological and evolutionary approaches to understanding Alternaria diseases of citrus. Molecular Plant Pathology 4: 435-446.

- Aleza P, Juárez J, Hernández M, Ollitrault P, Navarro L. 2009a. Recovery and characterization of a Citrus clementina Hort. ex Tan. 'Clemenules' haploid plant selected to establish the reference whole Citrus genome sequence. $B M C$ Plant Biology 9:110.

- Aleza P, Juárez J, Ollitrault P, Navarro L. 2009b. Production of tetraploid plants of non apomictic citrus genotypes. Plant Cell Reports 28: 1837-1846.

- Aleza P, Cuenca J, Juárez J, Pina JA, Navarro L. 2010a. 'Garbi' mandarin: a new latematuring triploid hybrid. Horticulture Science 45(1): 139-141.

- Aleza P, Juárez J, Cuenca J, Ollitrault P, Navarro L. 2010b. Recovery of citrus triploid hybrids by embryo rescue and flow cytometry from 2x x 2x sexual hybridisation and its application to extensive breeding programs. Plant Cell Reports 29(9): 1023-1034.

- Aleza P, Juárez J, Ollitrault P, Navarro L. 2010c. Polyembryony in nonapomictic citrus genotypes. Annals of Botany 106 : 533-545

- Aleza P, Froelicher Y, Schwarz S, Agustí M, Hernández M, Juárez J, Luro F, Morillon R, Navarro L, Ollitrault P. 2011. Tetraploidization events by chromosome doubling of nucellar cells are frequent in apomictic citrus and are dependent on genotype and environment. Annals of Botany 108(1): 37-50.

- Aleza P, Juárez J, Cuenca J, Ollitrault P, Navarro L. 2012a. Extensive citrus triploid hybrid production by $2 \mathrm{x} \times 4 \mathrm{x}$ sexual hybridizations and parent-effect on the length of the juvenile phase. Plant Cell Reports 31(9): 1723-1735.

- Aleza P, Juárez J, Hernández M, Ollitrault P, Navarro L. 2012b. Implementation of extensive citrus triploid breeding programs based on $4 \mathrm{x} \times 2 \mathrm{x}$ sexual hybridizations. Tree Genetics and Genomes 8(6): 1293-1306.

- Aleza P.2015. Workshop on New Mandarin Varieties. Acta Horticulturae 1065: 193-199. 
- Aleza P, Cuenca J, Hernández M, Juárez J, Navarro L, Ollitrault P. 2015. Genetic mapping of centromeres in the nine Citrus clementina chromosomes using half-tetrad analysis and recombination patterns in unreduced and haploid gametes. BMC plant biology 8: 15-80.

- Aleza P, Cuenca J, Juárez J, Navarro L, Ollitrault P. 2016a. Inheritance in doubled-diploid clementine and comparative study with SDR unreduced gametes of diploid clementine. Plant Cell Reports 35(8): 1573-1586.

- Aleza P, Garcia-Lor A, Juárez J, Navarro L. 2016b. Recovery of citrus cybrid plants with diverse mitochondrial and chloroplastic genome combinations by protoplast fusion followed by in vitro shoot, root, or embryo micrografting. Plant Cell, Tissue and Organ Culture (PCTOC) 126: 205-217.

- Aleza P, Velázquez K, Vives MC, Pina JA, Navarro L, Guerri J. 2016c. Development of a methodology for fruit quality early evaluation in citrus breeding programs. Proceedings of 13th International Citrus Congress Foz do Iguaçu 101.

- Allendorf FW, Danzmann RG. 1997. Secondary tetrasomic segregation of $\mathrm{MDH}-\mathrm{B}$ and preferential pairing of homeologs in rainbow trout. Genetics 145 : 1083-1092.

- Almeida RP, Nascimento FE, Chau J, Prado SS, Tsai CW, Lopes SA, Lopes JR. 2008. Genetic structure and biology of Xylella fastidiosa strains causing disease in citrus and coffee in Brazil. Applied and Environmental Microbiology 74: 3690-3701.

- Álvarez-Fernández A, Sierra MA, Lucena JJ. 2002. Reactivity of synthetic Fe chelates with soils and soil components. Plant and Soil 241: 129-137.

- Arbona V, Iglesias DJ, Jacas J, Primo-Millo E, Talon M, Gómez-Cadenas A. 2005. Hydrogel substrate amendment alleviates drought effects on young citrus plants. Plant and Soil 270: 73-82.

- Bañuls J, Serna MD, Legaz F, Talon M, Primo-Millo E. 1997. Growth and gas exchange parameters of Citrus plants stressed with different salts. Journal of Plant Physiology 150: 194-199.

- Bar-Joseph M, Marcus R, Lee RF. 1989. The continuous challenge of citrus tristeza virus control. Annual Revue of Phytopathology 27: 291-316.

- Barba-Gonzalez R, Lim K, Ramanna M, Visser R, Van Tuyl J. 2005. Occurrence of $2 \mathrm{n}$ gametes in the F1 hybrids of Oriental x Asiatic lilies (Lilium): Relevance to intergenomic recombination and backcrossing. Euphytica 143:6773.

- Barba-González R, Lim KB, Zhou S, Ramanna MS, Van Tuyl JM. 2008. Interspecfic hybridization in Lily: the use of $2 \mathrm{n}$ gametes in interspecific lily hybrids. In: Silva JAT, eds. Floriculture, Ornamental and Plant Biotechnology: Advances and Topical Issues, 1 edn. UK: Global Science Books 138-145 
- Barcaccia G, Tavoletti S, Mariani A, Veronesi F. 2003. Occurrence, inheritance and use of reproductive mutants in alfalfa improvement. Euphytica 133- 137.

- Barkley NA, Roose ML, Krueger RR, Federici CT. 2006. Assessing genetic diversity and population structure in a citrus germplasm collection utilizing simple sequence repeat markers (SSRs). Theoretical and Applied Genetics 112: 1519-1531.

- Barkley NA, Krueger RR, Federici CT, Roose ML. 2009. What phylogeny and gene genealogy analyses reveal about homoplasy in citrus microsatellite alleles. Plant Systematics and Evolution $\mathbf{2 8 2}$.

- Barone A, Gebhardt C, Frusciante L. 1995. Heterozygosity in 2 n gametes of potato evaluated by RFLP markers. Theoretical and Applied Genetics 91(1): 98104.

- Barrangou R, Doudna JA. 2016. Applications of CRISPR technologies in research and beyond. Nature biotechnology 34: 933-941.

- Barrett HC, Hutchison DJ. 1978. Spontaneous tetraploidy in apomictic seedlings of Citrus, Economic Botany 32: 27-45.

- Barrett HC, Rhodes AM. 1976. A numerical taxonomic study ofaffinity relationships in cultivated Citrus and its close relatives. Systematic Botany 1: 105-136.

- Bassanezi RB, Montesino LH, Stuchi ES. 2009. Effects of huanglongbing on fruit quality of sweet orange cultivars in Brazil. European Journal of Plant Pathology 125(4): 565-572.

- Bastiaanssen HJM, van dB, Lindhout P, Jacobsen E, Ramanna MS. 1998. Postmeiotic restitution in $2 n$-egg formation of diploid potato. Heredity 81: 2027.

- Batool A, Iftikhar Y, Mughal S, Khan M, Jaskani M, Abbas M, Khan I. 2007. Citrus Greening Disease-A major cause of citrus decline in the worldA Review. Horticultural Science 34: 159-166.

- Batra S. 1952. Induced tetraploidy in muskmelons. Journal of Heredity 43: 141148.

- Bayer RJ, Mabberley DJ, Morton C, Miller CH, Sharma IK, Pfeil BE, Rich S, Hitchcock R, Sykes S. 2009. A molecular phylogeny of the orange subfamily Rutaceae, Aurantioideae using nine cpDNA sequenceS. American Journal of Botany 96: 668-685.

- Beakbane AB. 1967. A relationship between leaf structure and growth potential in apple. Annals of Applied Biology 60: 67-76. 
- Bingham E, McCoy T. 1979. Cultivated alfalfa at the diploid level: origin, reproductive stability, and yield of seed and forage. Crop Science 19: 97-100.

- Boscariol RL, Monteiro M, Takahashi EK, Chabregas SM, Vieira MLC, Vieira LG, Pereira LF, de AA Mourão Filho, Francisco, Cardoso SC, Christiano RS. 2006. Attacin A Gene from Tricloplusia ni Reduces Susceptibility to Xanthomonas axonopodis pv. citri in Transgenic Citrus sinensis 'Hamlin'. Journal of the American Society for Horticultural Science 131: 530536.

- Bové JM. 2014. Huanglongbing or yellow shoot, a disease of Gondwanan origin: Will it destroy citrus worldwide? Phytoparasitica 42(5): 579-583.

- Bretagnolle F, Thompson JD. 1995. Tansley Review no-78 - Gametes with the somatic chromosome-number - mechanisms of their formation and role in the evolution of autopolyploid plants. New Phytologist 129: 1-22.

- Bretagnolle F. 2001. Pollen production and spontaneous polyploidization in diploid populations of Anthoxanthum alpinum. Biological Journal of the Linnean Society 72:241-247.

- Brlansky R, Damsteegt V, Hartung J. 2002. Transmission of the citrus variegated chlorosis bacterium Xylella fastidiosa with the sharpshooter Oncometopia nigricans. Plant Disease 86: 1237-1239.

- Broman KW, Rowe B, Churchill GA, Paigen K. 2002. Crossover interference in the mouse. Genetics 160: 1123-113.

- Brownfield L, Kohler C. 2011. Unreduced gamete formation in plants: mechanisms and prospects. Journal of Experimental Botany 62: 1659-1668.

- Butelli E, Licciardello C, Zhang Y, Liu J, Mackay S, Bailey P, ReforgiatoRecupero G, Martin C. 2012. Retrotransposons control fruit-specific, colddependent accumulation of anthocyanins in blood oranges. The Plant Cell 24: 1242-1255.

- Butelli E, Garcia-Lor A, Licciardello C, Las Casas G, Hill L, Recupero GR, Keremane ML, Ramadugu C, Krueger R, Xu Q, Deng X, Fanciullino AL, Froelicher Y, Navarro L, Martin C. 2017. Changes in Anthocyanin Production during Domestication of Citrus. Plant Physiology 173: 2225-2242.

- Cai X, Xu SS. 2007. Meiosis-driven genome variation in plants. Current Genomics 8(3): 151-161.

- Cameron JW, Bernett RH. 1978. Use of sexual tetraploid seed parents for production of triploid citrus hybrids. HortScience 13: 167-169.

- Cameroon J, Frost H. 1968. Genetic, breeding and nucellar embryony. In: Reuther W, Batchelor LD, Webber HJ, eds. The Citrus Industry. V2. University of California, Berkeley, U.S.A, 199-205. 
- Cameron JW, Soost RK. 1969. Characters of new populations of Citrus polyploids, and the relation between tetraploidy in the pollen parent and hybrid tetraploid progeny. Proceedings of the International Citric Symposium, University of California at Riverside 1: 199-205.

- Calabrese F, De Michele A, Barone F. 2000. New seedless lemon varieties for Sicily. IXth Congress of the International Society of Citriculture Orlando, Florida 114.

- Carbonell-Caballero J, Alonso R, Ibañez V, Terol J, Talon M, Dopazo JA. 2015. Phylogenetic Analysis of 34 Chloroplast Genomes Elucidates the Relationships between Wild and Domestic Species within the Genus Citrus. Molecular Biology and Evolution 32(8):2015-35.

- Carputo D, Frusciante L, Peloquin SJ. 2003. The role of 2 n gametes and endosperm balance number in the origin and evolution of polyploids in the tuber-bearing Solanums. Genetics 163:287-294.

- Carstens E, Linde CC, Slabbert R, Miles AK, Donovan NJ, Li H, Zhang K, Dewdney MM, Rollins JA, Glienke C, Schutte GC, Fourie PH, McLeod A. 2017. A Global Perspective on the Population Structure and Reproductive System of Phyllosticta citricarpa. Phytopathology 107(6):758-768.

- Caruso M, Merelo P, Distefano G, La Malfa S, Piero ARL, Tadeo FR, Talon M, Gentile A. 2012. Comparative transcriptome analysis of stylar canal cells identifies novel candidate genes implicated in the self-incompatibility response of Citrus clementina. BMC plant biology 12: 20.

- Castle B, Grosser J, Bowman K, Stover E. 2015. An HLB-tolerant citrus rootstock: What exactly does that mean? Citrus Industry 2015: 16-19.

- Castle WS. 2010. A career perspective on citrus rootstocks, their development, and commercialization. HortScience 45: 11-15.

- Cervera M, Ortega C, Navarro A, Navarro L, Pena L. 2000. Generation of transgenic citrus plants with the tolerance-to-salinity gene HAL2 from yeast. The Journal of Horticultural Science and Biotechnology 75: 26-30.

- Chambers SR, Hunter N, Louis EJ, Borts RH. 1996. The mismatch repair system reduces meiotic homeologous recombination and stimulates recombination-dependent chromosome loss. Molecular and Cellular Biology 1611: 6110-6120.

- Chen C, Gmitter Jr FG. 2013. Mining of haplotype-based expressed sequence tag single nucleotide polymorphismsin citrus. BMC genomics 14: 746.

- Chen C, Guo W, Yi H, Deng X. 2004. Cytogenetic analysis of two interspecific Citrus allotetraploid somatic hybrids and their diploid fusion parents. Plant Breeding 123: 332-337. 
- Chen C, Lyon MT, O'Malley D, Federici CT, Gmitter J, Grosser JW, Chaparro JX, Roose ML, Gmitter FG, Jr. 2008. Origin and frequency of $2 n$ gametes in Citrus sinensis x Poncirus trifoliata and their reciprocal crosses. Plant Science 174: 1-8.

- Chen C, Zhou P, Choi YA, Huang S, Gmitter Jr FG. 2006. Mining and characterizing microsatellites from citrus ESTs. Theoretical Applied Genetics 112:1248-1257.

- Chetelat RT, Meglic V, Cisneros PA. 2000. Genetic map of tomato based on BC1 Lycopersicon esculentum $\mathrm{x}$ Solanum lycopersicoides reveals overall synteny but suppressed recombination between these homeologous genomes. Genetics 1542: 857-867.

- Cifuentes M, Grandont L, Moore G, Chèvre AM, Jenczewski E. 2010. Genetic regulation of meiosis in polyploid species, New insights into an old question. New Phytologist 1861: 29-36.

- Contreras RN, Ranney T, Tallury SP. 2007. Reproductive Behavior of Diploid and Allotetraploid Rhododendron L., 'Fragrant Affinity'. HortScience 42: $31-34$

- Coulombe B, Chaney R, Wiebold W. 1984. Use of bicarbonate in screening soybeans for resistance to iron chlorosis. Journal of Plant Nutrition 7: 411-425.

- Crespel L, Gudin S. 2003. Evidence for the production of unreduced gametes by tetraploid Rosa hybrida L. Euphytica 133: 65-69.

- Cuenca J, Aleza P, Juárez J, Pina JA, Navarro L. 2010. 'Safor' mandarin: a new citrus midlate triploid hybrid. HortScience 45: 977-980.

- Cuenca J, Froelicher Y, Aleza P, Juárez J, Navarro L, Ollitrault P. 2011. Multilocus halftetrad analysis and centromere mapping in citrus: evidence of SDR mechanism for $2 \mathrm{n}$ megagametophyte production and partial chiasma interference in mandarin cv 'Fortune'. Heredity 107: 462-470.

- Cuenca J, Aleza P, Navarro L, Ollitrault P. 2013a. Assignment of SNP allelic configuration in polyploids using competitive allele-specific PCR: application to citrus triploid progeny. Annals of botany 111: 731-742.

- Cuenca J, Aleza P, Vicent A, Brunel D, Ollitrault P, Navarro L. 2013b. Genetically based location from triploid populations and gene ontology of a 3.3-Mb genome region linked to alternaria brown spot resistance in citrus reveal clusters of resistance genes. PloS One 8: e76755.

- Cuenca J, Aleza P, Juárez J, García-Lor A, Froelicher Y, Navarro L, Ollitrault P. 2015. Maximum-likelihood method identifies meiotic restitution mechanism from heterozygosity transmission of centromeric loci: application in citrus. Scientific Reports 5: 9897. 
- Cuenca J, Aleza P, Garcia-Lor A, Ollitrault P, Navarro L. 2016. Fine Mapping for Identification of Citrus Alternaria Brown Spot Candidate Resistance Genes and Development of New SNP Markers for Marker-Assisted Selection. Frontiers in Plant Science. 7:1948.

- Cuppen E. 2007. Genotyping by Allele-Specific Amplification (KASPar). CSH Protoc 2007: Cold Spring Harbor Protocols 4841.

- Curk F, Ancillo G, Garcia-Lor A, Luro F, Perrier X, Jacquemoud-Collet J, Navarro L, Ollitrault P. 2014. Next generation haplotyping to decipher nuclear genomic interspecific admixture in Citrus species, analysis of chromosome 2. BMC Genetics 15: 152.

- Curk F, Ancillo G, Ollitrault F, Perrier X, Jacquemoud-Collet J, GarciaLor A, Navarro L, Ollitrault P. 2015. Nuclear species-diagnostic SNP markers mined from 454 amplicon sequencing reveal admixture genomic structure of modern citrus varieties. PloS One 10:e0125628

- Curk F, Ollitrault F, Garcia-Lor A, Luro F, Navarro L, Ollitrault P. 2016. Phylogenetic origin of limes and lemons revealed by cytoplasmic and nuclear markers. Annals of Botany 117: 565-583.

- Dagulo L, Danyluk MD, Spann TM, Valim MF, Goodrich-Schneider R, Sims C, Rouseff R. 2010. Chemical characterization of orange juice from trees infected with citrus greening (Huanglongbing). Journal of Food Science 75: 199-207.

- Dambier D, Benyahia H, Pensabene-Bellavia G, Kacar YA, Froelicher Y, Belfalah Z, Lhou B, Handaji N, Printz B, Morillon R, Yesiloglu T, Navarro L, Ollitrault P. 2011. Somatic hybridization for citrus rootstock breeding: an effective tool to solve some important issues of the Mediterranean citrus industry. Plant Cell Reports 30(5): 883-900.

- Danzmann RG, Bogart JP. 1983. Further evidence for a polymorphism in gametic segregation in the tetraploid treefrog Hyla versicolor using a glutamate oxaloacetic transaminase locus. Genetics 103: 753-769.

- Davies FS, Albrigo LG. 1994. Citrus. Crops Production Science in Horticulture. CAB International, UK.

- de Moraes A, dos Santos Soares Filho W, Guerra M. 2007. Karyotype diversity and the origin of grapefruit. Chromosome Research 1: 115-121.

- De Storme N, Geelen D. 2013a. Cytokinesis in plant male meiosis. Plant Signaling and Behavior 8(3): e23394.

- De Storme N, Geelen D. 2013b. Sexual polyploidization in plants - cytological mechanisms and molecular regulation. New Phytologist 198: 670-684. 
- Del Bosco SF, Tusa N, Conicella C. 1999. Microsporogenesis in a Citrus interspecific tetraploid somatic hybrid and its fusion parents. Heredity 83: 373377.

- d'Erfurth I, Jolivet S, Froger N, Catrice O, Novatchkova M, Simon M, Jenczewski E, Mercier R. 2008. Mutations in AtPS1 (Arabidopsis thaliana parallel spindle lead to the production of diploid pollen grains. PLoS Genetics 4:e1000274

- d'Erfurth I, Cromer L, Jolivet S, Girard C, Horlow C, Sun Y, To JP, Berchowitz LE, Copenhaver GP, Mercier R. 2010. The cyclin-A CYCA1; 2/TAM is required for the meiosis I to meiosis II transition and cooperates with OSD1 for the prophase to first meiotic division transition. PLoS Genetics 6(6): e1000989.

- Dermen H. 1938. Detection of polyploidy by grain size: investigation with peaches and apricots. Proceedings of the American Society for Horticultural Science 35:96-103.

- Dewitte A, Van Laere K, Van Huylenbroeck J. 2012. Use of 2n gametes in plant breeding. In: DI Abdurakhmonov, eds. Plant Breeding. InTech 59-87.

- Dowling TE, Secor CL. 1997. The role of hybridization and introgression in the diversification of animals. Annual Review of Ecology and Systematics 28: 593619.

- Dowrick GJ. 1966. Breeding systems in tetraploid Rubus species. Genetical Research 7: 245-253.

- Drouaud J, Mercier R, Chelysheva L, Berard A, Falque M, Martin O, Zanni V, Brunel D, Mézard C. 2007. Sex-specific crossover distributions and variations in interference level along Arabidopsis thaliana chromosome 4. PLoS Genetics 3(6): e106.

- Duportal M, Jorda E, Sanchez C, Imbert É, Loeillet D, Vannière H. 2013. FruiTrop FOCUS Citron. FruiTrop Cirad 2013, 140. Available online at: http://www.fruitrop.com/media/Publications/FruiTrop-FOCUS

- Duran-Vila N, Janse J, Foissac X, Melgarejo P, Bové J. 2014. Addressing the threat of Huanglongbing in the Mediterranean region: a challenge to save the citrus industry. Journal of Plant Pathology 96: S4.3-S4.8.

- Dutt M, Barthe G, Irey M, Grosser J. 2016. Transgenic Citrus Expressing an Arabidopsis NPR1 Gene Exhibit Enhanced Resistance against Huanglongbing (HLB; Citrus Greening). PLOS ONE 11(1): e0147657.

- EPPO. 2017. https://gd.eppo.int/taxon/XANTCI

- Esen A, Soost RK. 1971. Unexpected triploids in Citrus: their origin, identification, and possible use. Journal of Heredity 62 (6): 329-333. 
- Esen A, Soost RK. 1972. Tetraploid progenies from $2 \mathrm{x} \times 4 \mathrm{x}$ crosses of Citrus and their origin, Journal of the American Society for Horticultural Science 97: 410-414.

- Esen A, Soost RK. 1973a. Precocious development and germination of spontaneous triploid seeds in Citrus. Journal of Heredity 64 (3): 147-154.

- Esen A, Soost RK. 1973b. Seed development in Citrus with special reference to 2x x 4x crosses. American Journal of Botany 60: 448-462.

- Esen A, Soost RK. 1975. Triploid progenies of Citrus cultivars from $2 x \times 2 x$ crosses. Journal of Heredity 66(3):177-178.

- Esen A, Soost RK, Geraci G. 1979. Genetic evidence for the origin of diploid megagametophytes in Citrus. Journal of Heredity 70: 5-8.

- Esselink G, Nybom H, Vosman B. 2004. Assignment of allelic configuration in polyploids using the MAC-PR (microsatellite DNA allele counting-peak ratios) method. Theoretical and Applied Genetics 109:402-408.

- Fang DQ, Federici CT, Roose ML. 1997. Development of molecular markers linked to a gene controlling fruit acidity in citrus. Genome 40: 841-849.

- FAOSTAT. 2014. http://www. fao.org/faostat

- Fatta Del Bosco S, Matranga G, Geraci G. 1992. Micro and macrosporogenesis of two triploid hybrids of citrus. Proceedings of 7th International Citrus Congress. International Society of Citriculture, Acireale, Italy 1: 122124.

- Federici CT, Fang DQ, Scora RW, Roose ML. 1998. Phylogenetic relationships within the genus Citrus (Rutaceae) and related genera as revealed by RFLP and RAPD analysis. Theoretical and Applied Genetics 94: 812-822.

- Ferrante SP, Lucretti S, Reale S, De Patrizio A, Abbate L, Tusa N, Scarano M. 2010. Assessment of the origin of new citrus tetraploid hybrids $(2 n=4 x)$ by means of SSR markers and PCR based dosage effects. Euphytica 173(2): 223233.

- Fjellstrom RG, Beuselinck PR, Steiner JJ. 2001. RFLP marker analysis supports tetrasomic inheritance in Lotus corniculatus L. Theoretical and Applied Genetics 102: 718-725.

- Froelicher Y, Luro F, Ollitrault P. 2000. Analysis of meiotic behaviour of tetraploid Clausena excavata species by molecular marker segregation studies. In: 9th International Society of Citriculture Congress, South Africa: 116. 
- Froelicher Y, Dambier D, Costantino G, Lotfy S, Didout C, Beaumont V, Brottier P, Risterucci A, Luro F, Ollitrault P. 2007. Characterization of microsatellite markers in Citrus reticulata Blanco. Molecular Ecology Note 5: 253-255.

- Froelicher Y, Dambier D, Bassene JB, Costantino G, Lotfy S, Didout C, Beaumont V, Brottier P, Risterucci AM, Luro F, Ollitrault P. 2008. Characterization of microsatellite markers in mandarin orange (Citrus reticulata Blanco). Molecular Ecology Resources 8(1): 119-122.

- Froelicher Y, Mouhaya W, Bassene JB, Costantino G, Kamiri M, Luro F, Morillon R, Ollitrault P. 2011. New universal mitochondrial PCR markers reveal new information on maternal citrus phylogeny. Tree Genetics and Genomes 7: 49-61.

- Frost HB, Soost RK. 1968. Seed reproduction, development of gametes and embryos. In: W Reuther, LD Batchelor, HJ Webber, eds. The Citrus Industry, Vol. 2. University of California Press, Berkeley, USA, 290-324.

- Frost HB. 1948. Genetics and breeding. In: W Reuther, HJ Webber, LD Batchelor, eds. The Citrus Industry, Vol. 1. University of California Press, Berkeley, USA, 817-914.

- Gallais A. 2003. Quantitative Genetics and Breeding Methods in Autopolyploids Plants, 2nd edn. Paris: INRA.

- Garcia-Lor A, Luro F, Navarro L, Ollitrault P. 2012a. Comparative use of InDel and SSR markers in deciphering the interspecific structure of cultivated citrus genetic diversity: a perspective for genetic association studies. Molecular Genetics and Genomics 287: 77-94.

- Garcia-Lor A, Garcia-Martinez J, Perez-Amador M. 2012b. Identification of ovule and seed genes from Citrus clementina. Tree Genetics and Genomes 8: 227-235.

- Garcia-Lor A, Ancillo G, Navarro L, Ollitrault P. 2013a. Citrus (Rutaceae) SNP markers based on Competitive Allele-Specific PCR; transferability across the Aurantioideae subfamily. Applications in Plant Sciences 1(4): apps.1200406.

- Garcia-Lor A, Curk F, Snoussi-Trifa H, Morillon R, Ancillo G, Luro F, Navarro L, Ollitrault P. 2013b. A nuclear phylogenetic analysis: SNPs, indels and SSRs deliver new insights into the relationships in the 'true citrus fruit trees' group (Citrinae, Rutaceae) and the origin of cultivated species. Annals of Botany 111(1):1-19.

- Garcia-Lor A, Luro F, Ollitrault P, Navarro L. 2015. Genetic diversity and population structure analysis of mandarin germplasm by nuclear, chloroplastic and mitochondrial markers. Tree Genetics and Genomes 11: 123.

- Geraci G, Esen A, Soost R. 1975. Triploid progenies 2x x 2x crosses of Citrus cultivars. Journal of Heredity 66:177-178. 
- Geraci G, De Pasquale F, Tusa N. 1977. Percentages of spontaneous triploids in progenies of diploid lemons and mandarins. Proceedings of the Second International Citrus Congress. International Society of Citriculture Orlando, Florida 2: 596-597.

- Gleba Y, Klimyuk V, Marillonnet S. 2007. Viral vectors for the expression of proteins in plants. Current opinion in biotechnology 18: 134-141.

- Gmitter FG Jr, Grosser JW, Moore GA. 1992. Citrus. In: F Hammerschlag, RL Litz, eds. Biotechnology of perennial crops. CAB Intl.: Wallingford, Oxon, U.K., 335-369.

- Gmitter FG, Soneji JR, Rao MN. 2009. Citrus breeding. In: Breeding Plantation Tree Crops: Temperate Species. Springer, 105-134.

- Golmohammadi M, Andrew M, Peever TL, Peres NA, Timmer LW. 2006. Brown spot of tangerine hybrid cultivars Minneola, Page and Fortune caused by Alternaria alternata in Iran. Plant Pathology 55(4): 578.

- Gomes, Mara de Menezes de Assis, Lagôa, Ana Maria Magalhães Andrade, Medina CL, Machado EC, Machado MA. 2004. Interactions between leaf water potential, stomatal conductance and abscisic acid content of orange trees submitted to drought stress. Brazilian Journal of Plant Physiology 16: 155-161.

- Gómez-Cadenas A, Tadeo F, Primo-Millo E, Talon M. 1998. Involvement of abscisic acid and ethylene in the responses of citrus seedlings to salt shock. Physiologia Plantarum 103: 475-484.

- Gottwald TR, da Graça JV, Bassanezi RB. 2007. Citrus huanglongbing: the pathogen and its impact. Plant Health Progress 6: 1-18.

- Gottwald TR, Graham JH, Schubert TS. 2002. Citrus canker: the pathogen and its impact. Plant Health Progress 10: 32.

- Grant V. 1981. Plant Speciation, 2nd ed. Columbia University Press, New York, USA.

- Griffiths AJF, Miller JH, Suzuki DT, Lewontin RC, Gelbart WM. 1996. An Introduction To Genetic Analysis Ed 6W H Freeman and Company, New York.

- Griffiths S, Sharp R, Foote TN, Bertin I, Wanous M, Reader S, Colas I, Moore G. 2006. Molecular characterization of $P h l$ as a major chromosome pairing locus in polyploid wheat. Nature 439: 749-752.

- Grosser JW, Gmitter FG Jr. 1990. Protoplast fusion and citrus improvement. Plant Breeding Reviews 8: 339-374.

- Grosser JW, Ollitrault P, Olivares-Fuster O. 2000. Somatic hybridization in citrus: An effective tool to facilitate variety improvement. In Vitro Cellular and Developmental Biology - Plant 36: 434-449. 
- Grosser JW, Gmitter Jr F. 2005. 2004 SIVB Congress Symposium Proceedings "Thinking outside the Cell": Applications of Somatic Hybridization and Cybridization in Crop Improvement, with Citrus as a Model. In Vitro Cellular and Developmental Biology 41(3): 220-225.

- Grosser JW, Chandler J, Duncan LW. 2007. Production of mandarin pummelo somatic hybrid citrus rootstocks with potential for improved tolerance/resistance to sting nematode. Scientia horticulturae113: 33-36.

- Grosser JW, An H, Calovic M, Lee D, Chen C, Vasconcellos M, Gmitter FG. 2010. Production of new allotetraploid and autotetraploid citrus breeding parents: focus on zipperskin mandarins. HortScience 45(8): 1160-1163.

- Grosser JW, Gmitter FG Jr. 2011. Protoplast fusion for production of tetraploids and triploids: applications for scion and rootstock breeding in citrus. Plant Cell Tissue and Organ Culture 104: 343-357.

- Grosser JW, Das S, Gmitter Jr F. 2014. Preliminary Evidence for Rootstock Effects on HLB Infection Frequency and Disease Severity in Sweet Orange and 'SugarBelle' Trees. Journal of Citrus Pathology 1:263-264.

- GVA.2015. http://www.mapama.gob.es/es/estadistica/temas/publicaciones. Superficies y producciones de cultivos.

- Hackett CA, Milne I, Bradshaw JE, Luo Z. 2007. TetraploidMap for Windows, Linkage map construction and QTL mapping in autotetraploid species. Journal of Heredity 98: 727-729.

- Hayashi M, Kato J, Ohashi H, Mii M. 2009. Unreduced 3x gamete formation of allotriploid hybrid derived from the cross of Primula denticulata $(4 \mathrm{x}) \times P$. rosea $(2 \mathrm{x})$ as a causal factor for producing pentaploid hybrids in the backcross with pollen of tetraploid P. denticulata. Euphytica 169: 123-131.

- He C, Li W, Ayres A, Hartung J, Miranda V, Teixeira D. 2000. Distribution of Xylella fastidiosa in citrus rootstocks and transmission of citrus variegated chlorosis between sweet orange plants through natural root grafts. Plant Disease 84: 622-626.

- Hearn CJ. 1969. Self-incompatibility and the effects of different pollen sources upon fruit characteristics of four Citrus hybrids. Proceeding of the American Society for Horticultural Science 87:183-187.

- Henrique FH, Zacarías L, Rodrigo MJ, Latado RR. 2016. Sanguinea de mombuca a novel red-fleshed brazilian orange accumulating lycopene and other colorless carotenes. Proceedings of 13th International Citrus Congress Foz do Iguaçu 104.

- Hensz RA. 1971. 'Star Ruby', a new deep-red-fleshed grapefruit variety with distinct tree characteristics. Journal of the Rio Grande Valley Horticultural Society 25: 54-58. 
- Herrero R, Asíns MJ, Carbonell EA, Navarro L. 1996. Genetic diversity in the orange subfamily Aurantioideae. I. Intraspecies and intragenus genetic variability. Theoretical and Applied Genetics 92: 599-609.

- Hickok LG. 1978. Homoeologous chromosome pairing: frequency differences in inbred and intraspecific hybrid polyploid ferns. Science 202: 982-984.

- Honsho, C. Yamamura, E. Tsuruta, K. Yoshimaru, Y. Yasuda, K. Uchida, A. Kunitake, H. Tetsumura, T. 2012. Unreduced 2n Pollen Production in 'Nishiuchi Konatsu' Hyuganatsu as Inferred by Pollen Characteristics and Progeny Ploidy Level. Journal of the Japanese Society for Horticultural Science 81:19-26.

- Honsho C, Sakata A, Tanaka H, Ishimura S, Tetsumura T. 2016. Singlepollen genotyping to estimate mode of unreduced pollen formation in Citrus tamurana cv. Nishiuchi Konatsu. Plant reproduction 29(1): 189-197.

- Husband BC. 2004. The role of triploid hybrids in the evolutionary dynamics of mixed-ploidy populations. Biological Journal of the Linnean Society 82: 537546.

- Hutchison DJ, Barrett HC. 1981. Tetraploid frequency in nucellar seedlings from single trees of Carrizo and Troyer Citrus hybrids. Proceedings of 4th International Citrus Congress, Tokyo: 27-29.

- Hutten R, Schippers M, Hermsen JT, Ramanna M. 1994. Comparative performance of FDR and SDR progenies from reciprocal $4 \mathrm{x}-2 \mathrm{x}$ crosses in potato. Theoretical applied genetics 89:545-550.

- Iwamasa M, Iwasaki T. 1963. On the sterility phenomenon caused by low temperatures in the Mexican lime (Citrus aurantifolia Swing.). Bulletin of the Horticultural Research Station of Japan, Series B 2: 25-45.

- Iwamasa M. 1966. Study on the steriliy in genus Citrus with special reference to the seedlessness. Bulletin of the Horticultural Research Station of Japan, Series B 6: 2-77.

- Iwamasa M. 1970. Chromosome aberrations in citrus in relation to sterility and seedlessnesS. 1st International Citrus Symposium, Riverside 1: 175-181.

- Iwamasa M. Nito N. 1988. Cytogenetics and the evolution of modern cultivated citrus. Proceedings of the Sixth International Citrus Congress, Margraf, Tel Aviv, Israel 1: 265-275.

- Iwanaga M, Freyre R, Orjeda G. 1991. Use of Ipomoea trifida (HBK.) G. Don germ plasm for sweet potato improvement. 1. Development of synthetic hexaploids of I. trifida by ploidy-level manipulations. Genome 34: 201-208.

- Iwasaki T. 1943. On the big leaf and small leaf strain of trifoliate orange (Poncirus trifoliata). Journal of the Horticultural Association of Japan 14: 302305. 
- Jackson R, Jackson JW. 1996. Gene segregation in autotetraploids: prediction from meiotic configurations. American Journal of Botany 83(6): 673-678.

- Jaskani MJ, Omura M, Khan IA. 2007. Cytogenetics. In: IA Khan, ed. Citrus Genetics, Breeding and Biotechnology. CABI: Wallingford, UK.

- Jenczewski E, Eber F, Grimaud A, Huet S, Lucas MO, Monod H, Chevre AM. 2003. PrBn, a major gene controlling homeologous pairing in oilseed rape Brassica napus haploids. Genetics 164: 645-653.

- Jeridi M, Perrier X, Rodier-Goud M, Ferchichi A, D'Hont A, Bakry F. 2012. Cytogenetic evidence of mixed disomic and polysomic inheritance in an allotetraploid AABB musa genotype. Annals of Botany 1108: 1593-1606.

- Jia H, Wang N. 2014. Targeted genome editing of sweet orange using Cas9/sgRNA. PloS One 9: e93806.

- Kamiri M, Stift M, Srairi I, Costantino G, El Moussadik A, Hmyene A, Bakry F, Ollitrault P, Froelicher Y. 2011. Evidence for non-disomic inheritance in a Citrus interspecific tetraploid somatic hybrid between $C$. reticulata and $C$. limon using SSR markers and cytogenetic analysis. Plant Cell Reports 30(8): 1415-1425.

- Karlov G, Khrustaleva L, Lim K, Van Tuyl J. 1999. Homoeologous recombination in 2 n-gametes producing interspecific hybrids of Lilium (Liliaceae) studied by genomic in situ hybridization (GISH).

- Khan IA, Kender WJ. 2007. Citrus breeding: introduction and objectives. In: IA Khan, ed. Citrus Genetics, Breeding and Biotechnology. CABI: Wallingford, UK.

- Kiely TB. 1948. Preliminary studies on Guignardia citricarpa, n. sp.: the ascigenous stage of Phoma citricarpaMcAlp. And its relation to black spot of citrus. Proceedings of the Linnean Society of New South Wales 68: 249-292.

- Kijas JMH, Fowler JC, Thomas MR. 1995. An evaluation of sequence tagged microsatellite site markers for genetic analysis within Citrus and related species. Genome 38: 349-355.

- Kijas JMH, Thomas MR, Fowler JCS, Roose ML. 1997. Integration of trinucleotide microsatellites into a linkage map of Citrus. Theoretical and Applied Genetics. 94(5): 701-706.

- Kobayashi S, Ieda I, Nakatani M. 1981. Role of the primordium cell in nucellar embryogenesis in citrus. Proceedings of 4th International Citrus Congress. International Society of Citriculture, Tokyo, Japan 1: 44-48.

- Koltunow AM, Brennan P, Protopsaltis S. 2000. Regeneration of West Indian limes (Citrus aurantifolia) containing genes for decreased seed set. ISHS Acta Horticulturae. First International Citrus Biotechnology Symposium 535: 81-91. 
- Koltunow AM. 1993. Apomixis: Embryo sacs and embryos formed without meiosis or fertilization in ovules. The Plant Cell 5: 1425-1437.

- Kotzé JM. 2000. Black spot. In LW Timmer, SM Garnsey, JH Graham, eds, Compendium of citrus diseases ( $2^{\text {nd }}$ ed) St. Paul: APS Press, 10-12

- Krajewski A, Rabe E. 1995. Citrus flowering: a critical evaluation. Journal of Horticultural Science 70: 357-374.

- Krug C. 1943. Chromosome number in the subfamily Aurantioideae with special reference to the genus Citrus. Botanical Gazette 104: 602-611.

- Krueger RR, Navarro L. 2007. Citrus germplasm resources. In: Khan IA, ed. Citrus Genetics, Breeding and Biotechnology. Wallingford, UK: CAB International 45-140.

- Lapin WK. 1937. Investigation on polyploidy in Citrus. U.S.S.R. All-Union Science Research Institute for Humid Sub-tropic Works 1(4):1-68.

- Lee LS. 1988. Citrus Polyploidy: Origins and Potential for Cultivar Improvement. Australian Journal of Agricultural Research 39: 735-747.

- Lee LS. 1990. Prospects for using citrus tetraploids for rootstocks. Proceedings of the Florida State Horticultural Society 108: 140-143.

- Legge J. 1865. The shoo king and The tribute of Yu. in The Chinese Classics. Trubner and Co., London Vol. 3, Pt. 1 and Pt. 3, Bk. 1, Chap. 6: 111-112.

- Liesebach H, Ulrich K, Ewald D. 2015. FDR and SDR processes in meiosis and diploid gamete formation in poplars (Populus L.) detected by centromereassociated microsatellite markers. Tree Genetics and Genomes 11:801

- Li DD, Shi W, Deng X. 2002. Agrobacterium-mediated transformation of embryogenic calluses of Ponkan mandarin and the regeneration of plants containing the chimeric ribonuclease gene. Plant Cell Reports 21: 153-156.

- Li DD, Shi W, Deng XX. 2003. Factors influencing Agrobacterium-mediated embryogenic callus transformation of Valencia sweet orange (Citrus sinensis) containing the pTA29-barnase gene. Tree Physiology 23: 1209-1215.

- Li L, Jean M, Belzile F. 2006. The impact of sequence divergence and DNA mismatch repair on homeologous recombination in Arabidopsis. The Plant Journal 456: 908-916.

- Li W, Berlyn GP, Ashton PMS. 1996. Polyploids and their structural and physiological characteristics relative to water deficit in Betula papyrifera (Betulaceae). American Journal of Botany 83: 15-20.

- Lian J, Yin Y, Oliver-Bonet M, Liehr T, Ko, E, Turek P, Sun F, Martin RH. 2008. Variation in crossover interference levels on individual chromosomes from human males. Human Molecular Genetics 17: 2583-2594. 
- Liang G, Xiong G, Guo Q, He Q, Li X. 2007. AFLP analysis and the taxonomy of Citrus. Acta Horticulturae 760: 137-142.

- Licciardello G, Grasso FM, Bella P, Cirvilleri G, Grimaldi. V, Catara V. 2006. Identification and Detection of Phoma tracheiphila, Causal Agent of Citrus Mal Secco Disease, by Real-Time Polymerase Chain Reaction. Plant Disease 90(12): 1523-1530.

- Liharska T, Wordragen M, Kammen A, Zabel P, Koornneef M. 1996. Tomato chromosome 6, effect of alien chromosomal segments on recombinant frequencies. Genome 393: 485-491.

- Lim KB, Shen T, Barba-Gonzalez R, Ramanna M, Van Tuyl JM. 2004. Occurrence of SDR 2N-gametes in Lilium hybrids. Breeding Science 54:13-18.

- Lim KB, Ramanna MS, de Jong JH, Jacobsen E, van Tuyl JM. 2001. Indeterminate meiotic restitution (IMR): a novel type of meiotic nuclear restitution mechanism detected in interspecific lily hybrids by GISH. Theoretical and Applied Genetics 103: 219-230.

- Longley AE. 1925. Polycarpy, polyspory and polyploidy in Citrus and Citrus relatives. Journal of the Washington Academy of Sciences 15: 347-357.

- Lotfy S, Luro F, Carreel F, Froelicher Y, Rist D, Ollitrault P. 2003. Application of Cleaved Amplified Polymorphic Sequence method for analysis of cytoplasmic genome among Aurantioideae intergeneric somatic hybrids. Journal of the American Society for Horticultural Science 128: 225-230.

- Louzada ES, Grosser JW, Gmitter FG Jr. 1993. Intergeneric somatic hybridization of sexually incompatible parents: Citrus sinensis and Atalantia ceylanica. Plant Cell Reports 12: 687-690.

- Lu C, Bridgen MP. 1997. Chromosome doubling and fertility study of Alstroemeria aurea x A. caryophyllaea. Euphytica 94: 75-81.

- Luro F, Lorieux M, Laigret F, Bove JM, Ollitrault P. 1994. Genetic mapping of an intergeneric Citrus hybrid using molecular markers. Fruits 49: 404-408.

- Luro F, Laigret F, Bove JM, Ollitrault P. 1995. DNA amplified fingerprinting, a useful tool for determination of genetic origin and diversity analysis in Citrus. HortScience 30: 1063-1067.

- Luro F, Maddy F, Ollitrault P, Rist D. 2000. Identification of 2n gamete parental origin and mode of nuclear restitution of spontaneous triploid Citrus hybrids. Proceedings of 9th International Citrus Congress. Orlando 1: 168-169.

- Luro F, Rist D, Ollitrault P. 2001. Evaluation of genetic relationships in Citrus genus by means of sequence tagged microsatellites. Proceedings of the International Symposium on Molecular Markers for Characterizing Genotypes and Identifying Cultivars in Horticulture. Montpellier 546: 537-542. 
- Luro F, Maddy F, Jacquemond C, Froelicher Y, Morillon R, Rist D, Ollitrault P. 2004. Identification and evaluation of diplogyny in clementine (Citrus clementina) for use in breeding. Acta Horticulturae 663(2): 841-848.

- Luro F, Costantino G, Terol J, Argout X, Allario T, Wincker P, Talon M, Ollitrault P, Morillon R. 2008. Transferability of the EST-SSRs developed on Nules clementine (Citrus clementina Hort ex Tan) to other Citrus species and their effectiveness for genetic mapping. BMC Genomics 9: 287.

- Maas E. 1992. Salinity and citriculture. Proceedings of the International Society of Citriculture Acireale 3: 1290-1301.

- Mable B, Alexandrou M, Taylor M. 2011. Genome duplication in amphibians and fish: an extended synthesis. Journal of zoology 284: 151-182.

- Maceira NO, De Haan AA, Lumaret R, Billon M, Delay J. 1992. Production of $2 \mathrm{n}$ gametes in diploid subspecies of Dactylis glomerata L. 1. Occurrence and frequency of $2 \mathrm{n}$ pollen. Annals of Botany 69:335-343.

- Manrique-Carpintero NC, Coombs JJ, Veilleux RE, Buell CR, Douches DS. 2016. Comparative Analysis of Regions with Distorted Segregation in Three Diploid Populations of Potato. G3, Genes, Genomes, Genetics 68: 26172628 .

- Manzaneda AJ, Rey PJ, Bastida JM, Weiss-Lehman C, Raskin E, Mitchell-Olds T. 2012. Environmental aridity is associated with cytotype segregation and polyploidy occurrence in Brachypodium distachyon (Poaceae). New Phytologist 193: 797-805.

- Marsden JE, Schwager SJ, May B. 1987. Single-locus inheritance in the tetraploid treefrog Hyla versicolor with an analysis of expected progeny ratios in tetraploid organisms. Genetics. 116(2): 299-311.

- Martín JJH, González JC. 2014. La fruticultura Del siglo XXI en España. Cajamar Caja Rural Climatic distribution of citrus black spot caused by Phyllosticta.

- Martínez-Minaya J, Conesa D, López-Quílez A, Vicent A. 2015. Climatic distribution of citrus black spot caused by Phyllosticta citricarpa. A historical analysis of disease spread in South Africa. European Journal of Plant Pathology. 143:69-83.

- Mau M, Corral JM, Vogel H, Melzer M, Fuchs J, Kuhlmann M, de Storme N, Geelen D, Sharbel TF . 2013. The conserved chimeric transcript UPGRADE2 is associated with unreduced pollen formation and is exclusively found in apomictic Boechera species. Plant Physiology 163:1640-1659.

- Mason AS, Nelson MN, Yan G, Cowling WA. 2011. Production of viable male unreduced gametes in Brassica interspecific hybrids is genotype specific and stimulated by cold temperatures. BMC Plant Biology 11:1. 
- Mason AS, Pires JC. 2015. Unreduced gametes: meiotic mishap or evolutionary mechanism? Trends in Genetics 31: 5-10.

- McCollum CD. 1958. Comparative studies of chromosome pairing in natural and induced tetraploid Dactylis. Chromosoma 9: 571-605.

- Mendiburu AO, Peloquin SJ. 1976. Sexual polyploidization and depolyploidization, some terminology and definitions. Theoretical and Applied Genetics 48: 137-143.

- Mendiburu A, Peloquin S. 1977a. The significance of $2 \mathrm{n}$ gametes in potato breeding. Theoretical Applied Genetics 49:53-61.

- Mendiburu AO, Peloquin S. 1977b. Bilateral sexual polyploidization in potatoes. Euphytica 26:573-583.

- Migheli Q, Cacciola SA, Balmas V, Pane A, Ezra D, di San Lio GM. 2009. Mal Secco Disease Caused by Phoma tracheiphila, A Potential Threat to Lemon Production Worldwide. Plant Disease 9: 852-867.

- Mok DWS, Peloquin SJ. 1975. Three mechanisms of $2 \mathrm{n}$ pollen formation in diploid potatoes. Canadian Journal of Genetics and Cytology 17: 217-225.

- Mok DWS, Peloquin SJ, Tarn T. 1975. Cytology of potato triploids producing 2n pollen. American Journal of Potato Research 52: 171-174.

- Monzo C, Arevalo HA, Jones MM, Vanaclocha P, Croxton SD, Qureshi JA, Stansly PA. 2015. Sampling Methods for Detection and Monitoring of the Asian Citrus Psyllid (Hemiptera: Psyllidae). Environmental Entomology 44: 780-788.

- Monzo C, Stansly PA. 2017. Economic injury levels for Asian citrus psyllid control in process oranges from mature trees with high incidence of huanglongbing. PloS One 12: e0175333.

- Moore GA. 2001. Oranges and lemons: clues to the taxonomy of Citrus from molecular markers. Trends in Genetics 17: 536-540.

- Morrison JW, Rajhathy T. 1960. Frequency of quadrivalents in autotetraploid plants. Nature 187: 528-530.

- Moreno P, Ambrós S, Albiach-Martí MR, Guerri J, Peña A. 2008. Citrus tristeza virus: a pathogen that changed the course of the citrus industry. MOLECULAR PLANT PATHOLOGY 9 (2): 251-268.

- Morton J. 1987. Mandarin lime. In, MORTON, J., eD., Fruits of warm climates, http,//wwW.,horT.,purduE.,edu/newcrop/morton/indeX.,html . 
- Nakamura M. 1943. Cytological and ecological studies on the genus Citrus with special reference to the occurrence of sterile pollen grains. Memoirs of the Faculty of Science and Agriculture, Taihoku Imperial University 27: 53-159.

- Nakano M, Nesumi H, Yoshioka T, Yoshida T. 2001. Segregation of plants with undeveloped anthers among hybrids derived from the seed parent, 'Kiyomi' (Citrus unshiu x C. sinensis). Journal of the Japanese Society for Horticultural Science 70(5): 539-545.

- Navarro L, Pina J, Juárez J, Ballester-Olmos J, Arregui J, Ortega C, Navrro A, Duran-villa N, Guerri J, Moreno P, Cambra M, Medina A, Zaragoza S. 2002. The citrus variety improvement program in Spain in the period 1975-2001. Proceedings of the 15th Conference of the International Organization of Citrus Virologists IOCV, Riverside: 306-316.

- Navarro L, Juárez J, Aleza P, Pina J, Olivares-Fuster O, Cuenca J, Julve J. 2005. Programa de obtención de híbridos triploides de mandarino en España. Phytoma 170: 36-41.

- Navarro L, Aleza P, Cuenca J, Juárez J, Pina JA, Ortega C, Navarro A, Ortega V. 2015. The mandarin triploid breeding program in Spain. Acta Horticulturae 1065: 389-396.

- Nekrasov V, Staskawicz B, Weigel D, Jones JD, Kamoun S. 2013. Targeted mutagenesis in the model plant Nicotiana benthamiana using Cas9 RNA-guided endonuclease. Nature biotechnology 31: 691-693.

- Nei M. 1978. Estimation of average heterozygosity and genetic distance from a small number of individuals. Genetics 89: 583-590.

- Nicolosi E, Deng ZN, Gentile A, Malfa S, Continella G, Tribulato E. 2000. Citrus phylogeny and genetic origin of important species as investigated by molecular markers. Theoretical and Applied Genetics 100: 1155-1166.

- Nicolosi E. 2007. Origin and taxonomy. In: Khan I, eds. Citrus genetics, breeding and biotechnology. CAB International: Wallington, 19-43.

- Ollitrault P, Dambier D, Jacquemont C, Allent V, Luro F. 1996. In vitro rescue and selection of spontaneous triploid by flow cytometry for easy peeler citrus breeding. Proceedings of the International Society of Citriculture Nelspruit 1: 254-258.

- Ollitrault P, Guo W, Grosser JW. 2007a. Somatic Hybridization. In: IA Khan, ed. Citrus Genetics, Breeding and Biotechnology. CABI: Wallingford, UK, 238.

- Ollitrault P, Luro F, Yamamoto M. 2007b. Seedlessness and ploidy manipulations. In: Khan I, eds. Citrus Genetics, Breeding and Biotechnology. CABI: Wallingford, UK 197-218

- Ollitrault P, Dambier D, Luro F, Froelicher Y. 2008. Ploidy manipulation for breeding seedless triploid citrus. Plant Breeding Reviews 30: 323-352. 
- Ollitrault F, Terol J, Pina JA, Navarro L, Talon M, Ollitrault P. 2010. Development of SSR markers from Citrus clementina (Rutaceae) BAC end sequences and interspecific transferability in Citrus. American Journal of Botany 97(11):e124-9

- Ollitrault P, Terol J, Garcia-Lor A, Bérard A, Chauveau A, Froelicher Y, Belzile C, Morillon R, Navarro L, Brunel D, Talon, M. 2012a. SNP mining in C. clementina BAC end sequences; transferability in the Citrus genus (Rutaceae), phylogenetic inferences and perspectives for genetic mapping. BMC Genomics 13: 13.

- Ollitrault P, Terol J, Chen C, Federici CT, Lotfy S, Hippolyte I, Ollitrault F, Bérard A, Chauveau A, Costantino G, Kacar Y, Mu L, Cuenca J, Garcia-Lor A, Froelicher Y, Aleza P, Boland A, Billot C, Navarro L, Luro F, Roose ML, Gmitter FG, Talon M, Brune D. 2012b. A reference genetic map of $C$. clementina hort. ex Tan.; citrus evolution inferences from comparative mapping. BMC Genomics 13: 593.

- Ollitrault P, Faure X. 1992. Système de reproduction et organisation de la diversité génétique dans le genre Citrus. In: Colloque international "Complexes d'espèces, flux de gènes et ressources génétiques des plantes", Paris, France, 0810 janvier 1992. Paris : Bureau des ressources Génétiques 12

- Ollitrault P, Navarro L. 2012. Citrus. In: M Badenes, D Byrne, eds. Fruit Breeding. Springer New York Dordrecht Heildelberg London, 623-662.

- Opperman R, Emmanuel E, Levy AA. 2004. The effect of sequence divergence on recombination between direct repeats in Arabidopsis. Genetics 1684: 2207-2215.

- Ortiz R. 1997. Occurrence and Inheritance of $2 n$ pollen in Musa. Annals of Botany 79: 449-453.

- Otto SP, Whitton J. 2000. Polyploid incidence and evolution. Annual Review of Genetics 34: 401-437.

- Otto SP. 2007. The evolutionary consequences of polyploidy. Cell 131: 452462.

- Pang X, Hu C, Deng X. 2007. Phylogenetic relationships within Citrus and its related genera as inferred from AFLP markers. Genetic Resources and Crop Evolution 54: 429-436.

- Park T, Kim J, Hutten RCB, van Eck HJ, Jacobsen E, Visser RGF. 2007. Genetic positioning of centromeres using half-tetrad analysis in a $4 x-2 x$ cross population of potato. Genetics $\mathbf{1 7 6}$.

- Parker JS, Palmer RW, Whitehorn MAF, Edgar LA. 1982. Chiasma frequency effects of structural chromosome change. Chromosoma. 85: 673-686. 
- Parrott W, Smith R, Smith M. 1985. Bilateral sexual tetraploidization in red clover. Canadian Journal of Genetics and Cytology 27:64-68.

- Peloquin S .1982. Meiotic mutants in potato breeding. Stadler Genetics Symposium 14:99-109.

- Peloquin S. 1983. Genetic engineering with meiotic mutants. In: Mulcahy DL, Mulcahy Bergamini G, Ottaviano E, eds. Pollen: Biology and implications for plant breeding. Elsevier, New York, 311-316.

- Peloquin SJ, Yerk GL, Werner JE, Darmo E. 1989. Potato breeding with haploids and 2n gametes. Genome 31(2): 1000-1004.

- Peña L, Martın TM, Juarez J, Pina JA, Navarro L, Martınez-Zapater JM. 2001. Constitutive expression of Arabidopsis LEAFY and APETALA1 genes in citrus reduces their generation time. Nature Biotechnology 19: 263-267.

- Peña L, Cervera M, Fagoaga C, Romero J, Ballester A, Soler N, Pons E, Rodriguez A, Peris J, Juarez J, Navarro L. 2008. Citrus. In: Chittaranjan K, Hall TC, eds. Compendium of transgenic crop plants.1-61

- Peng A, Chen S, Lei T, Xu L, He Y, Wu L, Yao L, Zou X. 2017. Engineering canker-resistant plants through CRISPR/Cas9-targeted editing of the susceptibility gene CsLOB1 promoter in citrus. Plant Biotechnology Journal n/a-n/a.

- Pérez-Tornero O, Córdoba F, Moreno M, Yuste L, Porras I. 2012. Classic methods and biotechnical tools in lemon breeding, preliminary results. Acta horticulturae 928: 259-263.

- Perrier X, Jacquemoud-Collet J. 2006. DARwin software. http://darwin.cirad.fr/darwin 5.0.158.

- Pons E, Navarro A, Ollitrault P, Peña L. 2011. Pollen Competition as a Reproductive Isolation Barrier Represses Transgene Flow between Compatible and Co-Flowering Citrus Genotypes. PloS One 610: e25810.

- Qi L, Friebe B, Zhang P, Gill BS. 2007. Homoeologous recombination, chromosome engineering and crop improvement. Chromosome Research. 15: 319.

- Ramadugu C, Keremane ML, Halbert SE, Duan YP, Roose ML, Stover E, Lee RF. 2016. Long-term field evaluation reveals Huanglongbing resistance in citrus relatives. Plant Disease 100: 1858-1869.

- Ramanna MS, Jacobsen E. 2003. Relevance of sexual polyploidization for crop improvement - A review. Euphytica 133: 3-8.

- Ramsey J, Schemske DW. 1998. Pathways, mechanisms, and rates of polyploid formation in flowering plants. Annual Review of Ecology and Systematics 29: 467-501. 
- Ramsey J, Schemske DW. 2002. Neopolyploidy in flowering plants. Annual Review of Ecology and Systematics 33:589-639.

- Ramsey J. 2007. Unreduced gametes and neopolyploids in natural populations of Achillea borealis. Heredity 98: 143-150.

- Ramsey J. 2011. Polyploidy and ecological adaptation in wild yarrow. Proceedings of the National Academy of Sciences of the United States of America 108: 7096-7101.

- Recupero GR, Russo G, Recupero S. 2005. New promising citrus triploid hybrids selected from crosses between monoembryonic diploid female ant tetraploid male parents. HortScience 40: 516-520.

- Reece PC, Childs JFL. 1962. Character differences among seedlings of the Persian lime. Florida State Horticultural Society 75: 110-116.

- Rhoades MM, Dempsey E. 1966. Induction of chromosome doubling at meiosis by the elongate gene in maize. Genetics 54:505-522.

- Romero P, Navarro J, Pérez-Pérez J, García-Sánchez F, Gómez-Gómez A, Porras I, Martinez V, Botía P. 2006. Deficit irrigation and rootstock: their effects on water relations, vegetative development, yield, fruit quality and mineral nutrition of Clemenules mandarin. Tree Physiology 26: 1537-1548.

- Ronfort J, Jenczewski E, Bataillon T, Rousset F. 1998. Analysis of population structure in autotetraploid species. Genetics 1502: 921-930.

- Roose M, Federici C, Mu L, Kwok K, Vu C. 2009. Map-based ancestry of sweet orange and other citrus variety groups. In: Gentile A, Tribulato E, eds. Second International Citrus Biotechnology Symposium. Catania, Italy 28.

- Roose ML, Williams TA, Soost RK, Cameron JW. 2002. US Patents: USPP 15,461, USPP 15,703, USPP 16,289. University of California, Riverside, USA.

- Roose ML, Williams TE. 2007. Mutation Breeding. In: IA Khan. Citrus Genetics, Breeding and Biotechnology. CABI: Wallingford, UK.

- Roose ML. 1988. Isozymes and DNA restriction fragment length polymorphisms in Citrus breeding and systematics. Proceedings of the 16th International Citrus Congress, Tel Aviv 155-165.

- Rosenberg O. 1927. Die Semiheterotypische Teilung und Ihre Bedeutung für die Entstehung verdoppelter Chromozomenzahlen. Hereditas 8: 305-358.

- Rouiss H, Cuenca J, Navarro L, Ollitrault P, Aleza P. 2017a. Tetraploid citrus progenies arising from FDR and SDR unreduced pollen in $4 \mathrm{x} \times 2 \mathrm{x}$ hybridizations. Tree Genetics and Genomes 13: 10. 
- Rouiss H, Cuenca J, Navarro L, Ollitrault P, Aleza P. 2017b. Unreduced Megagametophyte Production in Lemon Occurs via Three Meiotic Mechanisms, Predominantly Second-Division Restitution. Frontiers in Plant Science. doi: 10.3389/fpls.2017.01211.

- Ruiz C, Asins MJ. 2003. Comparison between Poncirus and Citrus genetic linkage maps. Theoretical and Applied Genetics 106: 826-36.

- Ruiz C, Paz Breto M, Asins M. 2000. A quick methodology to identify sexual seedlings in citrus breeding programs using SSR markers. Euphytica 112: 89-94.

- Ruiz M, Quiñones A, Martínez-Alcántara B, Aleza P, Morillon R, Navarro L, Primo-Millo E, Martínez-Cuenca M. 2016. Effects of salinity on diploid $(2 \mathrm{x})$ and doubled diploid $(4 \mathrm{x})$ Citrus macrophylla genotypes. Scientia Horticulturae 207: 33-40.

- Russo F, Torrisi M. 1951. Il poliploidismo nei Citrus Autopoliploidi e allopoliploidI. Annali della Sperimentazione Agraria 5: 1041-1062.

- Russo G, Recupero S, Puglisi A, Recupero G. 2004. New triploid citrus hybrids by Italian genetic improvement. Rivista di Frutticoltur $e$ di Ortofloricoltura 66: 14-18.

- Sanford JC, Moore JN, Janick J. 1983. Ploidy manipulations. In: Moore JN, Janick J, eds. Methods in fruit breeding. Purdue University Press, West Lafayette 100-123.

- Scora RW, Kumamoto J, Soost RK, Nauer EM. 1982. Contribution to the origin of the grapefruit Citrus paradisi (Rutaceae). Systematic Botany 7: 170177.

- Scora RW. 1975. On the history and origin of citrus. Bulletin of the Torrey Botanical Club 102: 369-375.

- Scora RW. 1988. Biochemistry, taxonomy and evolution of modern cultivated Citrus. In: Goren R, Mendel K, eds. Proceedings of the 6th International Citrus Congress., Balaban Publishers; Weikersheim, Germany: Margraf Scientific Books edn: Philadelphia/Rehovot, 277-289.

- Sdiri S, Bermejo A, Aleza P, Navarro P, Salvador A. 2012. Phenolic composition, organic acids, sugars, vitamin $\mathrm{C}$ and antioxidant activity in the juice of two new triploid late-season mandarins. Food Research International 49(1): 462-468.

- Senthil-Kumar M, Mysore KS. 2011. Caveat of RNAi in plants: the off-target effect. RNAi and Plant Gene Function Analysis: Methods and Protocols 744: $13-25$.

- Shan Q, Wang Y, Li J, Zhang Y, Chen K, Liang Z, Zhang K, Liu J, Xi JJ, Qiu J. 2013. Targeted genome modification of crop plants using a CRISPR-Cas system. Nature biotechnology 31: 686-688. 
- Shepherd K. 1999. Cytogenetics of the genus musa. International Network for the Improvement of Banana and Plantain: Montpellier: IPGRI.

- Shokrollah H, Abdullah TL, Sijam K, Abdullah SNA. 2010. Ultrastructures of Candidatus Liberibacter asiaticus and its damage in huanglongbing (HLB) infected citrus. African Journal of Biotechnology 9: 5897-5901.

- Soltis DE, Soltis PS. 1993. Molecular data and the dynamic nature of polyploidy. Critical Reviews in Plant Sciences 12: 243-273.

- Soler N, Plomer M, Fagoaga C, Moreno P, Navarro L, Flores R, Peña L. 2012. Transformation of Mexican lime with an intron-hairpin construct expressing untranslatable versions of the genes coding for the three silencing suppressors of Citrus tristeza virus confers complete resistance to the virus. Plant biotechnology journal 10(5): 597-608.

- Soneji JR, Chen CX, Rao MN, Huang S, Choi YA, Gmitter FG Jr. 2007. Agrobacterium, mediated transformation of citrus using two binary vectors. Acta Horticulturae 738: 261-264.

- Soost RK. 1969. The incompatibility gene system in Citrus. Proceedings of the 1st International Citrus Symposium 1: 189-190.

- Spiegel-Roy P, Goldschmidt EE. 1996. Biology of Citrus. Press syndicate of the University of Cambridge, Cambridge.

- Spiegel-Roy P, Vardi A, Yaniv Y, Fanberstein L, Elhanati A, Carmi N. 2007. 'Ayelet' and 'Galya', New seedless lemon cultivars. Horticultural Science 42: $1723-1724$.

- Stanley RG, Linskens HF. 1974. Pollen, Biology Biochemistry Management. New York: Springer.

- Starrantino A, Recupero GR. 1981. Citrus hybrids obtained in vitro from $2 \mathrm{x}$ females and 4x male. Proceedings of the International Society of Citriculture Tokyo 1: 31-32.

- Strasburger E. 1910. Sexuelle und apogame. Fortpflanzung bei Urtica queen 47: 245-288.

- Stebbins G. 1947. Types of polyploids: their classification and significance. Advances in Genetics 1: 1939.

- Stebbins Jr C. 1950. Variation and Evolution in Plants. New York: Columbia Univ. Press.

- Stift M, Berenos C, Kuperus P, van Tienderen PH. 2008. Segregation models for disomic, tetrasomic and intermediate inheritance in tetraploids: a general procedure applied to Rorippa (yellow cress) microsatellite data. Genetics 179(4): 2113-2123. 
- Swingle W, Reece P. 1967. The botany of Citrus and its wild relatives. In: Reuther W, Webber HJ, Batchelor LD, eds. The citrus industry. The botany of Citrus and its wild relatives. Berkeley CA: University of California 1: 190-430.

- Sybenga J. 1975. Meiotic configurations. Monograph on theoretical and applied genetics. Berlin: Springer-Verlag.

- Sybenga J. 1995. Meiotic pairing in autohexaploid lathyrus, a mathematical model. Heredity 754: 343-350.

- Sybenga J. 1996. Chromosome pairing affinity and quadrivalent formation in polyploids: do segmental allopolyploids exist? Genome 39: 1176-1184.

- Sybenga J. 2012. Cytogenetics in plant breeding. Springer Science and Business Media.

- Syvertsen J, Levy Y. 2005. Salinity interactions with other abiotic and biotic stresses in citrus. HortTechnology 15: 100-103.

- Tachikawa T, Tanaka Y, Hara S. 1961. Investigation on the breeding of Citrus trees. Study on the breeding of triploid Citrus varieties. Bulletin of the Shizuoka Prefectural Citrus Experiment Station 4: 33-44.

- Tai GCC. 1986. Biometrical genetical analysis of tetrasomic inheritance based on matings of diploid parents which produce 2 n gametes. Heredity 57:315-317.

- Tanaka T. 1954. Species problem in Citrus (Revisio Aurantiacearum IX). Japanese Society for Promotion of Science, Tokyo, Japan.

- Tanaka T. 1961. Citologia: Semi-centennial Commemoration Papers on Citrus Studies. Citologia Supporting Foundation, Osaka 114.

- Tatineni S, Sagaram US, Gowda S, Robertson CJ, Dawson WO, Iwanami T, Wang N. 2008. In planta distribution of 'Candidatus Liberibacter asiaticus' as revealed by polymerase chain reaction (PCR) and real-time PCR. Phytopathology 98: 592-599.

- Tavoletti S, Bingham ET, Yandell BS, Veronesi F, Osborn TC. 1996. Half tetrad analysis in alfalfa using multiple restriction fragment length polymorphism markers. Proceedings of the National Academy of Sciences of the United States of America 93(20): 10918-10922.

- Terol J, Naranjo MA, Ollitrault P, Talon M. 2008. Development of genomic resources for Citrus clementina, characterization of three deep-coverage BAC libraries and analysis of 46,000 BAC end sequences. BMC Genomics 9: 423.

- Timmer LW, Peever TL, Solel Z, Akimitsu K. 2003. Alternaria diseases of citrus-novel pathosystems. Phytopathologia Mediterranea 42: 99-112.

- Torres AM, Soost RK, Diedenhofen U. 1978. Leaf isozymes as genetic markers in Citrus. American Journal of Botany 65: 869-881. 
- Torres AM, Soost RK, Mau-Lastovicka T. 1982. Citrus isozymes: Genetics and distinguishing nucellar from zygotic seedlings. Journal of Heredity 73: 335338.

- Uzun A, Gulsen O, Kafa G, Seday U. 2008. 'Alata', 'Gulsen', and 'Uzun' Seedless Lemons and 'Eylul' Early-maturing Lemon. Horticultural Science 43(6): 1920-1921.

- Van de Peer Y, Maere S, Meyer A. 2009. The evolutionary significance of ancient genome duplications. Nature Reviews Genetics 10: 725-732.

- Van Tuyl JM, De Jeu MJ. 1997. Methods for overcoming interspecific crossing barriers. In: Sawhney VK. Shivanna KR, eds. Pollen biotechnology for crop production and improvement. Cambridge Univ. Press, N.Y 273-292.

- Vardi A, Levin I, Carmi N. 2008. Induction of seedlessness in Citrus: From classical techniques to emerging biotechnological approaches. Journal of the American Society for Horticultural Science 133: 117-126.

- Velázquez K, Agüero J, Vives MC, Aleza P, Pina JA, Moreno P, Navarro L, Guerri J. 2016. Precocious flowering of juvenile citrus induced by a viral vector based on Citrus leaf blotch virus: a new tool for genetics and breeding. Plant biotechnology journal 14: 1976-1985.

- Vicent A, Armengol J, Sales R, García-Jiménez J, Alfaro-Lassala F. 2000. First Report of Alternaria Brown Spot of Citrus in Spain. Plant Disease 84(9): 1044.

- Viloria Z, Grosser JW. 2005. Acid citrus fruit improvement via interploid hybridization using allotetraploid somatic hybrid and autotetraploid breeding parents. Journal of the American Society for Horticultural Science 130: 392402.

- Voorrips RE. 2002. MapChart, Software for the Graphical Presentation of Linkage Maps and QTLS. Journal of Heredity 93: 77-78.

- Vorsa N, Rowland LJ. 1997. Estimation of $2 n$ megagametophyte heterozygosity in a diploid blueberry (Vaccinium darrowi Camp) clone using RAPDs. Journal of Heredity 88(5): 423-426.

- Wakana A, Iwamasa M, Uemoto S. 1982. Seed development in relation to ploidy of zygotic embryo and endosperm in polyembryonic Citrus. Proceedings of the International Society of Citriculture Tokyo 35-9.

- Wakana A, Uemoto S. 1988. Adventive embryogenesis in citrus (Rutaceae) II. Postfertilization development. American Journal of Botany 75: 1033-1047.

- Wang X, Xu Y, Zhang S, Cao L, Huang Y, Cheng J, Wu G, Tian S, Chen C, Liu Y. 2017. Genomic analyses of primitive, wild and cultivated citrus provide insights into asexual reproduction. Nature genetics 49: 765-772. 
- Wang XF, Li ZA, Tang KZ, Zhou CY, Yi L. 2010. First report of Alternaria Brown Spot of Citrus caused by Alternaria alternata in Yunnan Province, China. Plant Disease 94(3): 375.

- Warner DA, Edwards GE. 1993. Effects of polyploidy on photosynthesis. Photosynthesis Research 35: 135-147.

- Warner DA, Edwards GE. 1989. Effects of Polyploidy on Photosynthetic Rates, Photosynthetic Enzymes, Contents of DNA, Chlorophyll, and Sizes and Numbers of Photosynthetic Cells in the C(4) Dicot Atriplex confertifolia. Plant Physiology 91: 1143-1151.

- Watanabe K, Peloquin SJ .1993. Cytological basis of $2 \mathrm{n}$ pollen formation in a wide range of $2 \mathrm{x}, 4 \mathrm{x}$, and $6 \mathrm{x}$ taxa from tuber-bearing Solanum species. Genome 36:8-13.

- Webber HJ, Reuther W, Lawton H. 1967. History and development of the citrus industry. In: Reuther W, Webber HJ, Batchelor LD, eds. The citrus industry. The botany of Citrus and its wild relatives. Berkeley CA: University of California, 1: 1-39.

- Wendel JF. 2000. Genome evolution in polyploids. Plant molecular evolution 42: 225-249.

- Wendel J, Doyle J. 2005. Polyploidy and evolution in plants. In: Henry RJ, eds. Plant diversity and evolution. Genotypic and phenotypic variation in higher plants. CAB International, Wallingford, U. K. 97-117.

- White P, Robson A. 1990. Response of lupins (Lupinus angustifolius L.) and peas (Pisum sativum L.) to Fe deficiency induced by low concentrations of $\mathrm{Fe}$ in solution or by addition of HCO 3. Plant and Soil 125: 39-47.

- Williams T, Roose M. 2004. 'TDE2' Mandarin hybrid (Shasta Gold $\AA$ Mandarin), 'TDE3' Mandarin hybrid (Tahoe Gold® Mandarin) and 'TDE4' Mandarin hybrid (Yosemite Gold® Mandarin): three new mid and late-season triploid seedless mandarin hybrids from California. Proceedings of 10th international citrus congress, vol 1, International Society of Citriculture, Agadir1: 394-398.

- Winge ö. 1917. The chromosomes: Their numbers and general importance. Comptes-rendus des travaux du Laboratoire Carlsberg 13: 131-175. 
- Wu GA, Prochnik S, Jenkins J, Salse J, Hellsten U, Murat F, Perrier X, Ruiz M, Scalabrin S, Terol J, Takita MA, Labadie K, Poulain J, Couloux A, Jabbari K, Cattonaro F, Del Fabbro C, Pinosio S, Zuccolo A, Chapman J, Grimwood J, Tadeo FR, Estornell LH, Munoz-Sanz JV, Ibanez V, HerreroOrtega A, Aleza P, Perez-Perez J, Ramon D, Brunel D, Luro F, Chen C, Farmerie WG, Desany B, Kodira C, Mohiuddin M, Harkins T, Fredrikson K, Burns P, Lomsadze A, Borodovsky M, Reforgiato G, Freitas-Astua J, Quetier F, Navarro L, Roose M, Wincker P, Schmutz J, Morgante M, Machado MA, Talon M, Jaillon O, Ollitrault P, Gmitter F, Rokhsar D. 2014. Sequencing of diverse mandarin, pummelo and orange genomes reveals complex history of admixture during citrus domestication. Nature biotechnology 32: 656-662.

- Xie K, Wang X, Biswas MK, Liang W, Xu Q, Grosser JW, Guo W. 2014. 2n megagametophyte formed via SDR contributes to tetraploidization in polyembryonic 'Nadorcott' tangor crossed by citrus allotetraploids. Plant Cell Reports 33:1641-1650.

- Xie K, Xia Q, Wang X, et al. 2015. Cytogenetic and SSR-marker evidence of mixed disomic, tetrasomic, and intermediate inheritance in a citrus allotetraploid somatic hybrid between 'Nova tangelo and 'HB'pummelo. Tree Genetics and Genomes 11: 112.

- Xu Q, Chen L, Ruan X, Chen D, Zhu A, Chen C, Bertrand D, Jiao W, Hao B, Lyon MP. 2013. The draft genome of sweet orange (Citrus sinensis). Nature genetics 45: 59-66.

- Yamamoto M, Kobayashi S, Yoshioka T, Matsumoto R. 2001. Cybridization in Citrus unshiu Marc. (Satsuma Mandarin) and C. sinensis (L.) Osbeck (Sweet Orange). In: T Nagata, YPS Bajaj, eds. Somatic Hybridization in Crop Improvement II: Biotechnology in Agriculture and Forestry. Springer Berlin Heidelberg 49: 124-138.

- Yamasaki A, Kitajima A, Ohara N, Tanaka M, Hasegawa K. 2009. Characteristics of arrested seeds in Mukaku Kishu-type seedless citrus. Journal of the Japanese Society for Horticultural Science 78: 61-67.

- Yokomi RK. 2009. Citrus tristeza virus. Options Méditerranéennes Série B : 19-33.

- Youds JL, Mets DG, McIlwraith MJ, Martin JS, Ward JD, Oneil NJ, Rose AM, West SC, Meyer BJ, Boulton SJ. 2010. RTEL-1 enforces meiotic crossover interference and homeostasis. Science 327: 1254-1258.

- Younis A, Hwang Y, Lim K. 2014. Exploitation of induced 2n-gametes for plant breeding. Plant Cell Reports 33: 215-223.

- Zadoo SN, Roy RP, Khoshoo TN. 1975. Cytogenetics of cultivated bougainvilleas. V. Induced tetraploidy and restoration of fertility in sterile cultivars. Euphytica. 24: 517-524. 
- Zaragoza S. 2007. Aproximación a la historia de los cítricos. Origen, dispersión y evolución de su uso y cultivo. Tesis doctoral. Universidad Politécnica de Valencia. Departamento de Producción Vegetal, Valencia, España.

- Zhu S, Wu B, Ma Y, Chen J, Zhong G. 2013. Obtaining citrus hybrids by in vitro culture of embryos from mature seeds and early identification of hybrid seedlings by allele-specific PCR. Scientia Horticulturae 161: 300-305.

- Zlesak DC. 2009. Pollen diameter and guard cell length as predictors of ploidy in diverse rose cultivars, species, and breeding lines. Floriculture Ornamental Biotechnology 3:53-70. 